oc

Le.

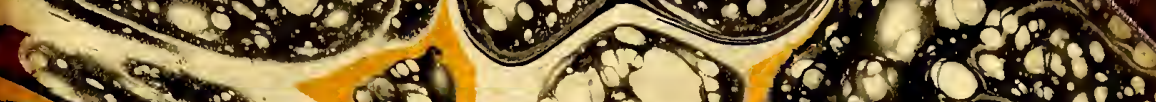

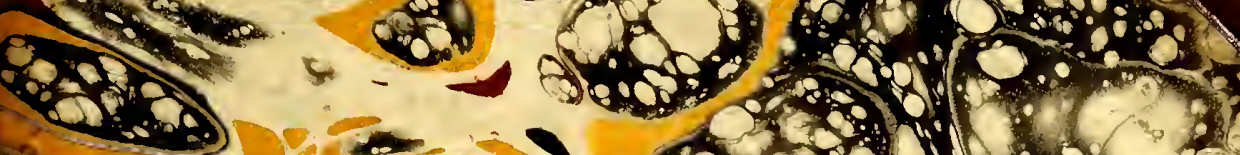

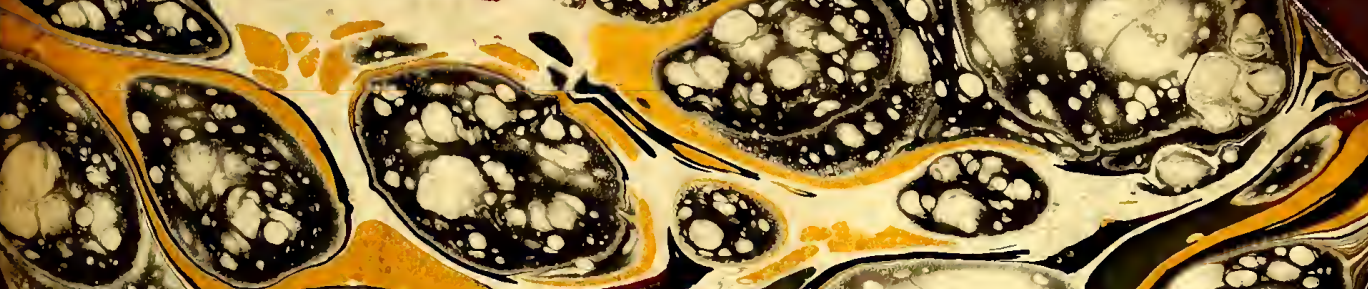

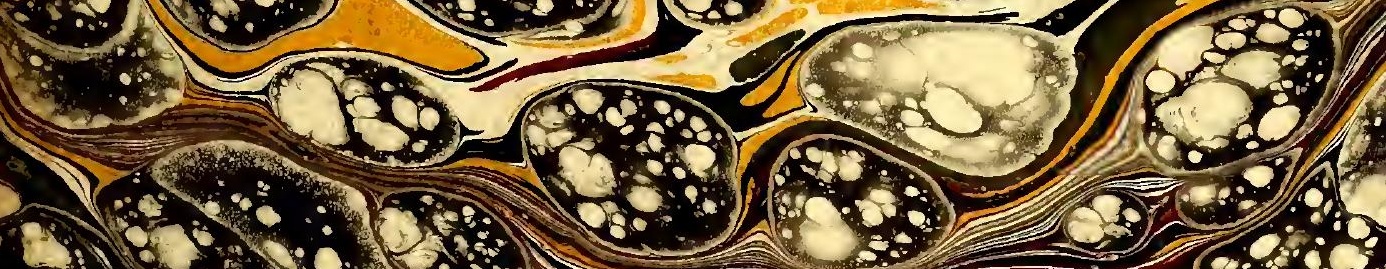

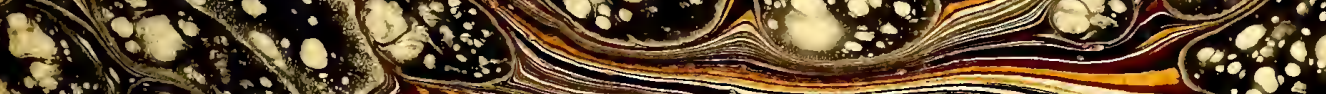

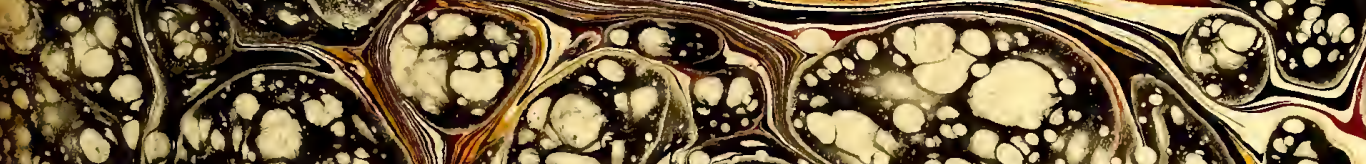

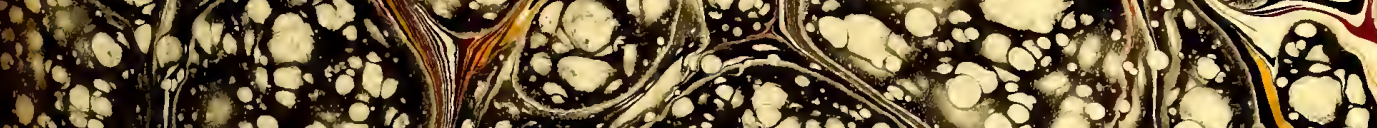

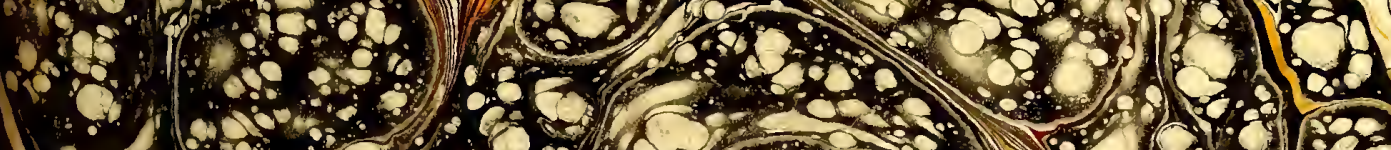

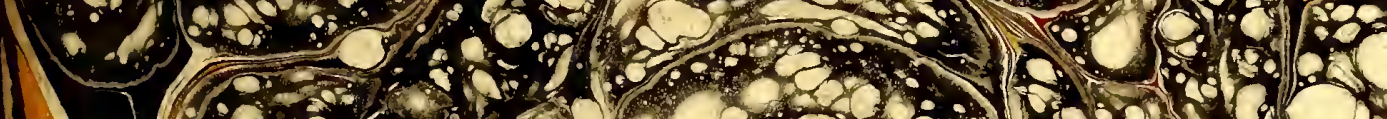

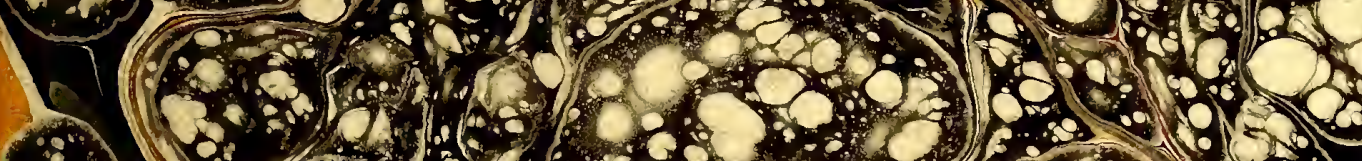

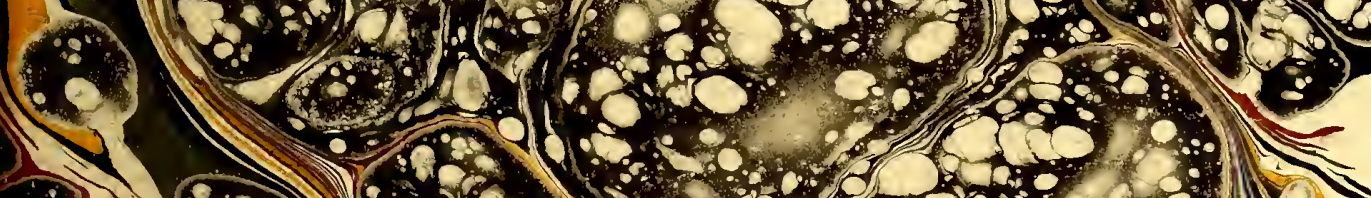

Silos.

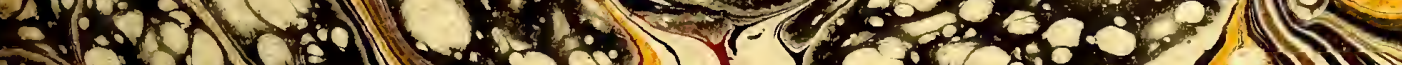

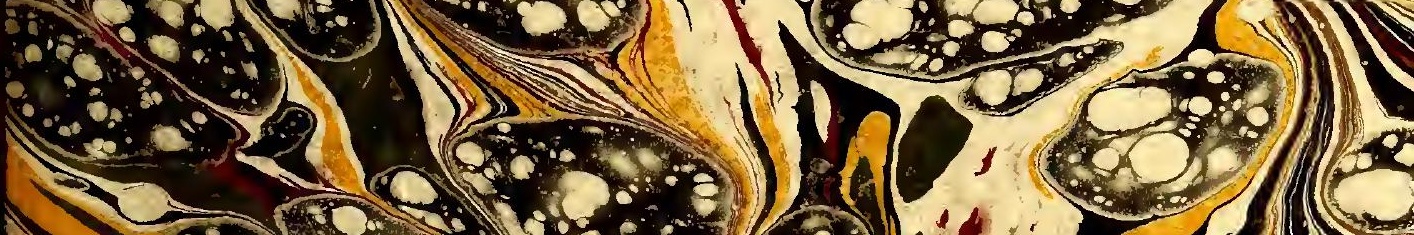

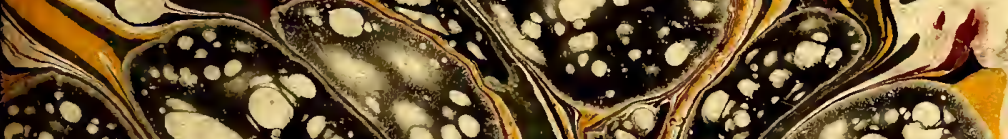
20 . Q

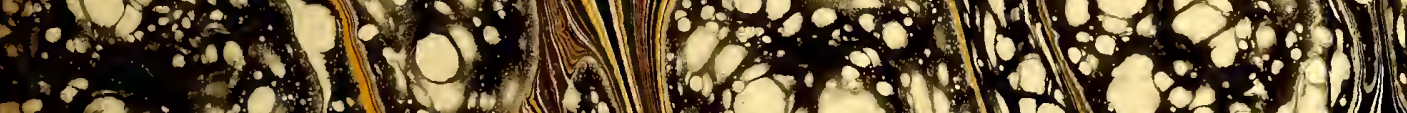

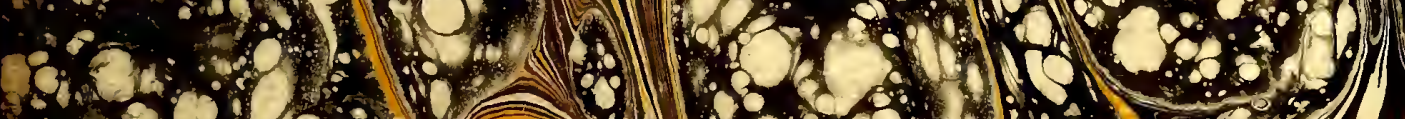

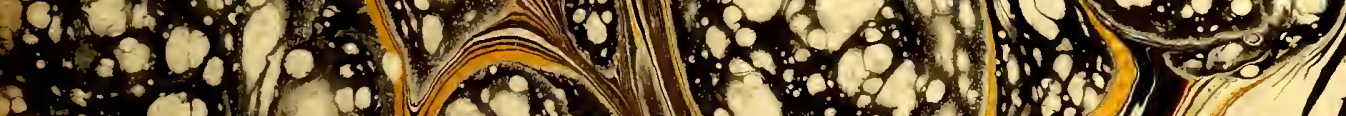

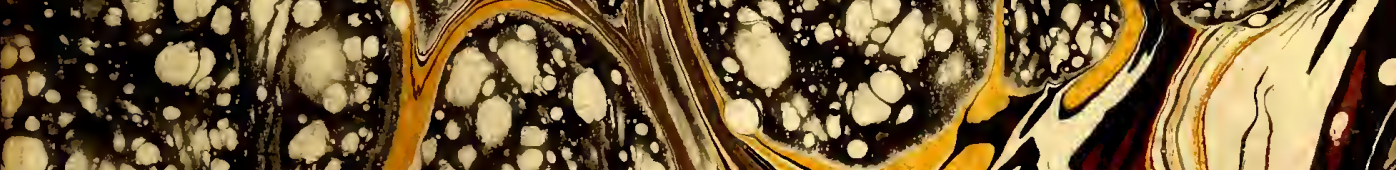

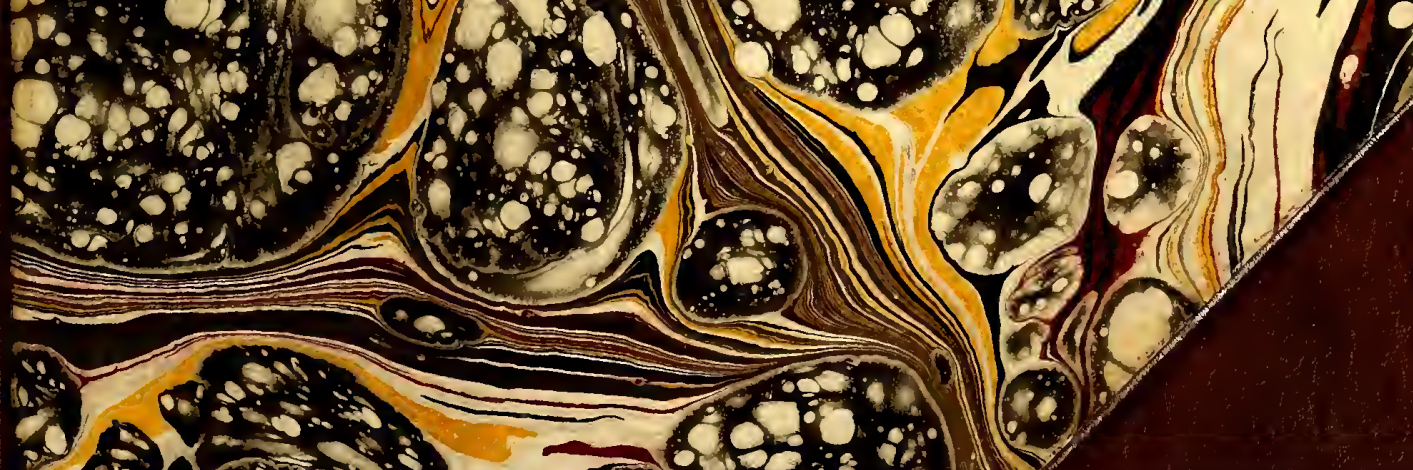



$\times \times A 1863900$

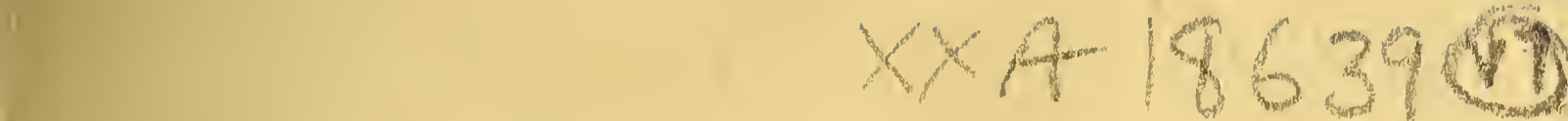





\section{HISTORICAL ACCOUNT - OF}

DISCOVERIES AND TRAVELS 


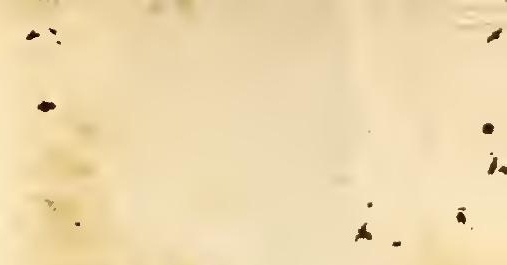

$\checkmark$

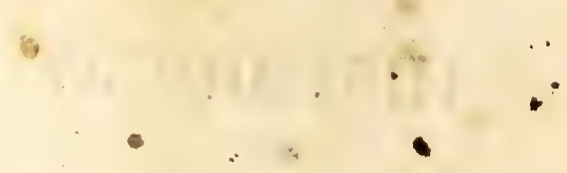




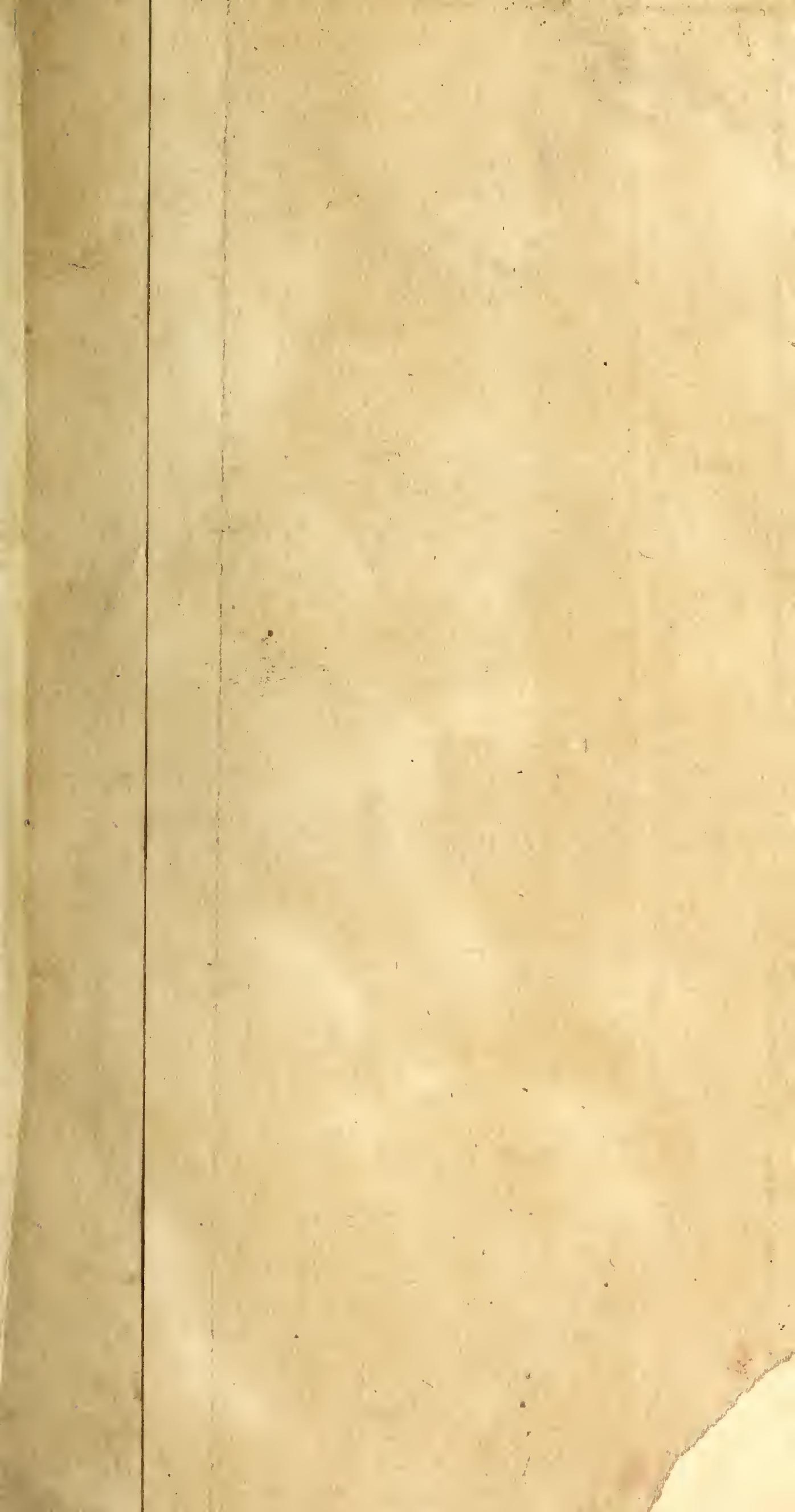




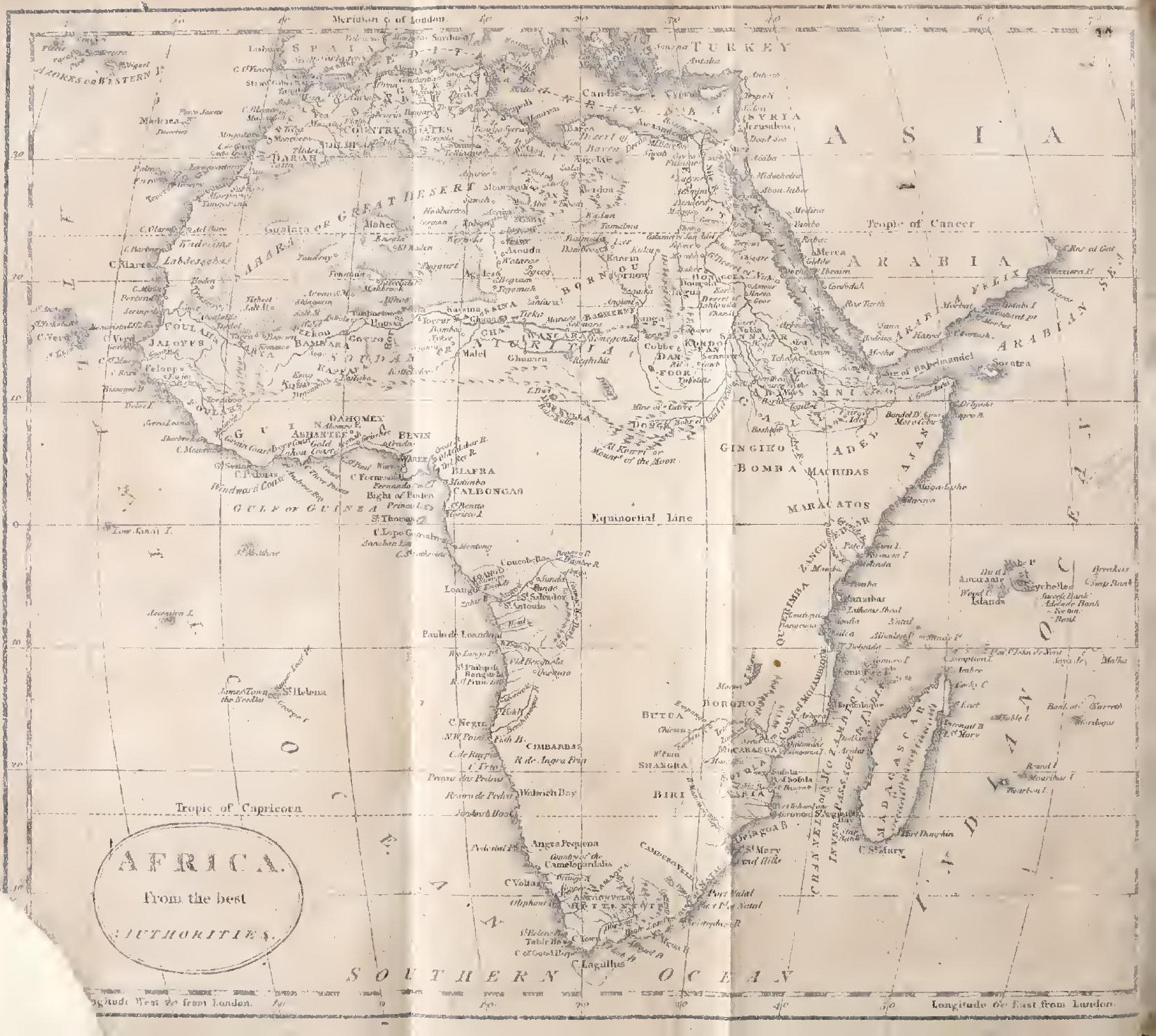





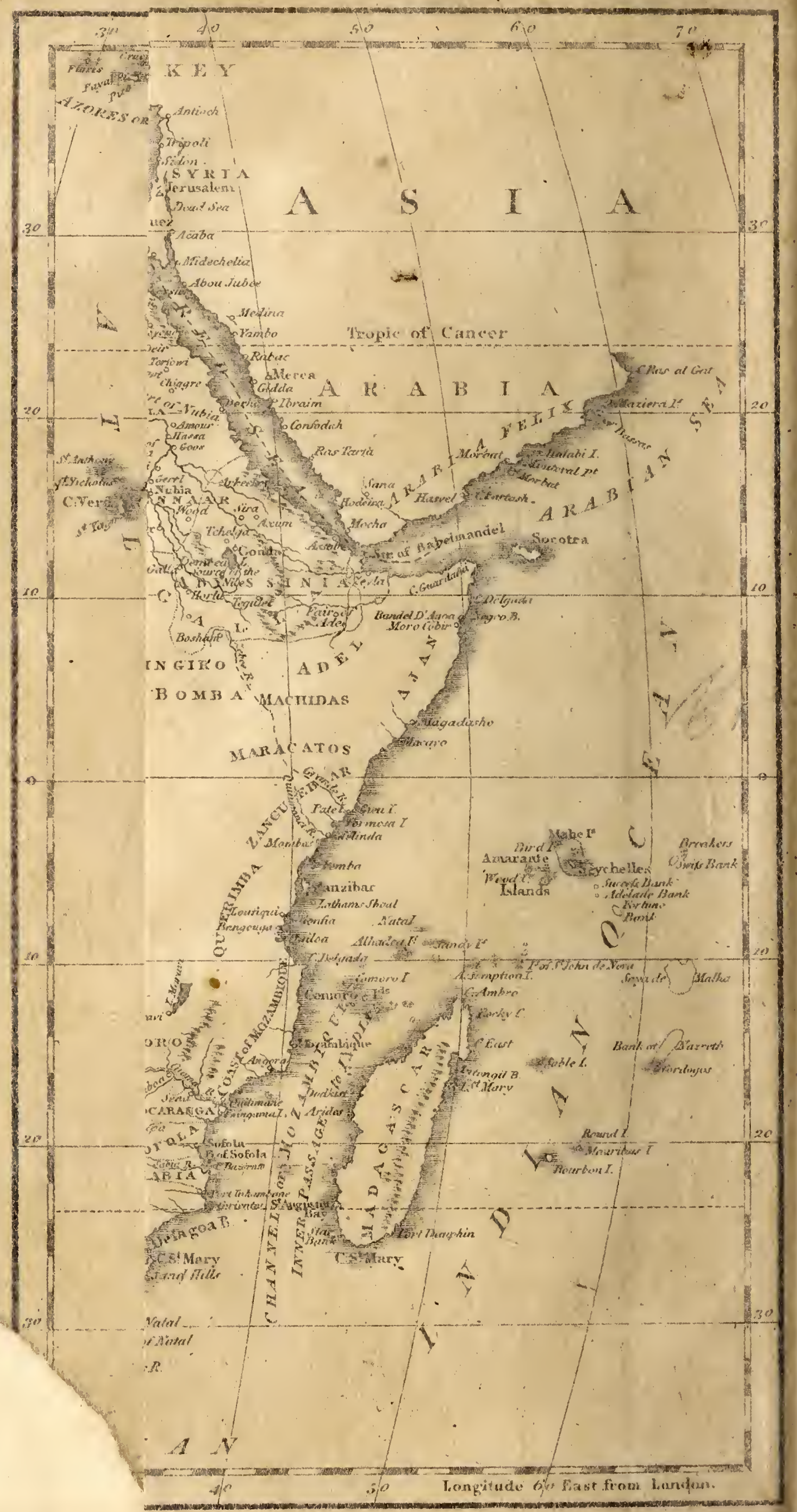




\title{
HISTORICAL ACCOUNT
}

\section{" \\ 政iscoberies and $\mathbb{T r a b e l s}$ \\ IN AFRICA,}

BY THE LATE JOHN LEYDEN, M. D.

\author{
ENLARGED,
}

AND COMPLETED TO THE PRESENT TIME,

WITH

ILLUSTRATIONS OF ITS GEOGRAPHY

AND NATURAL HISTORY, AS WELL AS OF THE MORAL AND SOCIAL CONDITION OF ITS INHABITANTS.

By HUGH MURRAY, Eso. F. R. S. E.

VOL. I.

\section{EDINBURGH :}

PRINTED BY GEORGE RAMSAY AND COMPANY, FOR ARCHIBALD CONSTABLE AND COMPANY, EDINBURGII; AND LONGMAN, HURST, REES, ORME, AND BROWN, LONDON. 



\section{DT

TO THE RIGHT HONOURABLE

\section{SIR JOSEPH BANKS, K. B.}

PRESIDENT OF THE ROYAL SOCIETY,

WHOSE UNREMITTING EFFORTS

TO PROMOTE THE PROGRESS OF DISCOVERY

THROUGHOUT THE AFRICAN CONTINENT,

AS WELL AS

THE WORLD IN GENERAL,

ESTABLISH A JUST CLAIM TO

THE GRATITUDE OF HIS COUNTRY,

THIS WORK

IS

MOST RESPECTFULLY. DEDICATED,

BY

HUGH MURRAY. 



\section{PREFACE.}

The progress of discovery in Africa has long been an object of peculiar interest; nor can it be difficult to trace the sources from which that interest has arisen. This immense Continent contains in its bosom a number of extensive, populous, and even civilized kingdoms, all of them imperfectly known, and of some of which even the names have not yet reached Europeans. Equally remarkable is the obscurity which involves the grandest features of its physical geography. Africa, therefore, is still humbling to that pride of knowledge, which Europe very justly indulges, with regard to the other quarters of the globe. An extraordinary zeal, however, to remove this re- 
proach, has been for some time manifested in this country; and seconded and aided as that zeal now is by government, a series of splendid discoveries may be expected to be the result; so that it is more than probable, that, in the course of fifteen or twenty years, Africa will lose its place in the list of unknown regions.

In order, however, that these discoveries may be understood and appreciated by the general reader, some preliminary knowledge seems requisite. It is impossible duly to estimate what one traveller has done without knowing what had been effected by his predccessors in the same tract; the perusal of the one naturally excites curiosity with regard to the other. But the narratives of former travellers are dispersed through a multitude of books, often of difficult access, and loaded with tedious and uninteresting details. A work seemed wanted, which might collect from these various sources whatever was most curious and interesting, and might thence form a connected view of the progress of discovery from the earliest ages. 
The writer who first attempted to supply this important desideratum, was Dr Leyden, in the work which forms the basis of the present publication. * To those who have any knowledge of our recent literary history, it cannot be necessary to point out the circumstances which peculiarly qualified Dr Leyden for this task; his depth of research, his force of imagination, and, to use the emphatic expressions of Lord Minto, " his incomparable genius, urging and sus"taining his invincible powers of mental " labour." $\dagger \mathrm{He}$ entered upon it with all

* A Historical and Philosophical Sketch of the Discoveries and Settlements of Europeans in Northern and Western Africa, at the close of the eighteenth century. 12mo, 442 pages. Edinburgh, 1799.

† "It is impossible," says Lord Minto, in his Address to the College of Fort William, " to exclude from our " minds the painful recollection of a loss sustained by " this College, by the votaries of eastern learning, and, "I will not refrain from adding, by the lovers of genius " and worth, yet more estimable than all other endow" ments, in the premature and lamented death of $\mathrm{Dr}$ " Leyden. It is not required, it would not be fitting, " in this place, to repress entirely the sentiments with 
that ardour and enthusiasm which formed prominent features in his character. "A"frica," says a biographer who intimately knew him, "had peculiar charms for Ley"den. He delighted to read of hosts, " whose arrows intercepted the sunbeams; " of kings, who judged of the number of " their soldiers, by marching them over " the trunk of a cedar; of the royal halls " of Dahomy, built of sculls and cross " bones; all,in short, that presented strange, "wild, and romantic views of what have " been quaintly entitled the ultimities and " summities of human nature, and which " furnished new and unheard of facts in the " history of man, had great fascination for " his ardent imagination." * So completely

" which this event has filled every bosom, capable of ap" preciating, and when appreciated, of honouring alive, " and deploring in the grave, an example of excellence " intellectual and moral, so rare and eminent. I must " restrain, however, even the justifiable effusion of public " regret, heightened, as it is, by private sorrow on this " mournful theme; not for the poverty of the subject, " or the coldness of affection, but for their abundance " and excess."

* Edinburgh Annual Register, 1811. 
were his views directed to African discovery, that he actually made overtures to the Association for being employed as one of their missionaries. All the energies of his mind were, therefore, put forth upon this subject; and having taken Raynal for his model, he hoped, with the pride of conscious genius, not to fall much short of his standard. The work, when published, was found to correspond to the efforts of genius and industry, with which it had been composed. It soon obtained a wide circulation, not only in this country, but over the Continent. It was translated into German, * and is enumerated by Eichhorn among the most valuable materials for the African part of his learned work, entitled, "History of the "Three last Centuries." M. de la Richarderie also repeatedly notices it with praise in his valuable work, the "Bibliotheque des Voyages."

This work having now become scarce, a new edition has for some time been con-

* Historische und philosophische Skizze der Entdeckungen et Niederlassungen der Europaer in Nord und West Africa, um ende der achtzehnten Jahrhunderts. Aus dem Engl. von S. St. Bremen, 8vo, 1802. 
templated. Indeed, Dr Leyden himself had actually undertaken one on a more extended scale, embracing the whole continent. A small part was actually written, and is included in these volumes; but his departure for India unfortunately prevented its completion. In the present work, the object has been, not only to include the whole of Africa, but to trace the progress of discovery from the earliest ages. How far this difficult undertaking has been successfully performed, must be left to the judgment of the reader.

It was my original wish to preserve the portion of the narrative composed by $\mathrm{Dr}$ Leyden, distinct from the additions made to it. On considering, however, the general enlargement which it was necessary to give to the work, it appeared that such a plan would have broke down entirely its unity and connection. It seemed of more importance to the public to receive a distinctly arranged view of the subject, than to be able to distinguish, at a glance, the contributions of its respective authors. There appeared a necessity, therefore, for 
taking down, as it were, the parts of Dr Leyden's performance, and arranging them anew, in the more comprehensive plan which is now adopted.*

In the present arrangement, the two introductory chapters trace the progress of discovery, from the earliest ages to the commencement of maritime enterprise in modern Europe. The First Book then follows the progress of modern discovery in the interior, and this subject, being of peculiar interest, occupies the whole of the first volume. Under this head, it has been necessary to include those parts of the coast

* The following list will enable the reader at once to trace the parts of the work for which he is indebted to Dr Leyden.

Book I. Chap. IV. Travels in the Sahara, I. p. 263-285. V. TheAfrican Association, p. 286_327. VI. Park's First Journey, p. 328_396. -VII. Browne's Journey, p. 397-415. Book II. Chap. II. Description of Egypt (published for the first time), II. p. 104-196. IV. The Western Coast, p. 255-306.

The rest of the work it has been necessary to supply from other sources, 
by which the attempts to penetrate inward have been chiefly made, - as Congo, and the banks of the Senegal and Gambia. The Second Book exhibits the discoveries in the maritime countries, beginning with Abyssinia, the chief native power, and making thence the circuit of Africa. The Third Book is occupied with geographical illustrations and views of the present state of Africa. Under the former head, it is attempted to exhibit, as a branch of the history of science, a view of the progress of inquiry and speculation relative to this continent, from the earliest ages, rather than to indulge in present conjectures, which, a few years, it may be hoped, would render superfluous. In this part of the work I have been fortunate enough to obtain from my friend, Professor Jameson, a general view of the natural history of Africa, the great importance of which cannot fail to be appreciated by every reader.

In the Appendix will be found translations of some scarce and curious passages of the early geographers, relating to central Africa, which, though often referred to, are 
rarely accessible to the general reader. A list is annexed of the best works tending to illustrate the geography of this Continent, which, it is hoped, will be found useful to those who wish to make deeper researches into that interesting subject.

The maps accompanying this work have been executed with the greatest care, and from the most recent and authentic materials. The historical maps attached to the third book can be considered only as sketches, without any attempts at minute accuracy. It is hoped, however, that they will be found to contain an accurate expression of the general ideas entertained by geographical inquirers, at these successive periods, of the form and constituent parts of the African Continent. 



\title{
CONTENTS
}

\author{
OF \\ VOLUME I.
}

\section{INTRODUCTION.}

\section{CHAPTER I. \\ DISCOVERIES OF THE ANCIENTS.}

Division of the Ancient World into Continents.-Mediterranean Coast.-Influence of poetical ideas._Curiosity of the Ancients respecting the interior.-Attempts to circumnavigate Africa; Phenicians under Necho; Sataspes; Eudoxus.-Voyages along the Western Coast; Hanno ; Scylax ; Polybius._Eastern Coast; Evemerus ; Arrian's Periplus.-Attempts to penetrate into the interior; the Nasamones; Cambyses; Alexander; Roman Expeditions, - Page \&

\section{CHAPTER II.}

DISCOVERIES DURING THE MIDDLE AGES.

The Arabians.-Their Entrance into Africa; their Es. tablishment on the Niger.-Kingdoms of Ghana, Wangara, \&c.-Limits of their Knowledge.-Leo Africanus.-Changes in Central Africa.-Foundation of Tombuctoo.-Description of that City.-Ghinea. -Melli_-Gualata, VOL. I. 


\section{BOOK I.}

DISCOVERIES AND TRAVELS IN THE INTHRIOIR OF AFRIEA.

\section{CHAPTER I.}

DISCOVEIIES OF THE PORTUGUESE, AND TRAVEES IN CONGO.

Early Voyages along the Western Coast._Prester John. -Establishment at Arguin.-Expedition to the Senegal.-Early Accounts of Tombuctoo and Jenné.Discovery of, and Voyage up the Congo, by Diego Cam.-Conversion of the Monarch to Christianity.Missions to the Upper Part of the Congo._Batta.Pango.-Sundi.-Esseno.-Concobella.-Mission to Matamba ; Zingha._To Maopongo._-Voyage of Carli._Of Merolla._Of Battel.-De Grandprés Ac. count of the present State of Congo.-Descriptions, by various Authors, of the Origin and Course of the Congo,

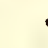

CHAPTER II.

Page 48

DISCOVERIES OF THE FRENCH.

French African Companies.-Jannequin.-First Voyage of Brue; the Siratik.-Second voyage of Brue; Gallam ; Accounts of Bambarra and Tombuctoo.-Third voyage of Brue; the Gum trade-Compagnon; Bambouk; its Gold mines._Adanson._Saugnier, 146

CHAPTER. III.

EARLY DISCOVERIES OF THE ENGLISH.

First Voyages to the Senegal and Gambia.-Plans for penetrating to Tombuctoo.-Thompson.-Jobson.Vermuyden._Stibbs._Job-Ben.Solomon.-Moore, 210

\section{CHAPTER IV.}

TRAVELS IN THE SAHARA, OR GREAT DESERT.

General View of the Great Desert.-Adventures of Saugnier.-'The Monselemines.-The Mongearts.-Brisson. -The Ouadelim and Labdesseba, 
CHAPTER V.

THE AFRICAN ASSOCIATION.

Institution of the Association._Ledyard.-Lucas.Description of Fezzan, Bornou, and Cashna.-Watt and Winterbottom's Journey to Foota Jallo._Major Houghton,

\section{-
CHAPTER VI.
PARK'S FIRST JOURNEY.}

Arrival of Mr Park.-Pisania.-Yani.-Medina.-Bondou._Kajaaga._Kassan._Kaarta._Account of the Lotus.-War between Kaarta and Bambarra.-Trarels and detention in Ludamar.- Escape through the Wilderness to Bambarra.-Travels in Bambarra to Silla, and return along the Niger.-Travels in Manding, and hospitable reception at Kamaliah.-Travels in Jallonkadoo.-Konkodoo, Satadoo, and Dentila._Account of Fuota Torra.-Return to Pisania, - - 328

\section{CHAPTER VII.}

MR BROWNE'S JOURNEY.

Departure from Assiut.-Arrival and residence in Darfûr.-Description of that Country.-Begarmee.Bergoo.-Darkulla._Donga._The Bahr.el-Abiad, 397

\section{CHAPTER VIII.}

FURTHER PROCEEDINGS OF THE AFRICAN ASSOCIATION.

Horneman.-His Departure from Cairo._Journey through the Desert.-Siwah.-Remains of Ammon.Augila._Fezzan._The Tibbo and Tuarick.-Interior of Africa.-Nicholls._Roentgen._L'Hagi Mahommed.-Jackson,

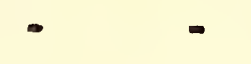

- $\quad 416$ 


\section{CHAPTER IX.}

MR PARK'S SECOND JOURNEY.

Plan of a new Expedition to the Niger.-Undertaken by Mr Park.-His arrival at Goree.-Departure.Beginning of the rainy season.-Alarming sickness.Washing for Gold.-Depredations of the Natives.Arrival on the Niger.-Interview with Mansong's Prime Minister.-Residence at Sansanding.-Builds a boat, and sets sail._Reports of his death._Particulars, as narrated by Amadi Fatouma, - Page 438

\section{CHAPTER X.}

\section{ADAMS'S NARRATIVE.}

Shipwreck of Adams.- His Journey through the Desert. -Soudenny.-Arrival at Tombuctoo.-Description of that city.-Journey across the Great Desert.Captivity among the Arabs.-Ransom.-Observations on his Account of the Political State of Tombuctoo, 468

\section{CHAPTER XI.}

RILEY'S NARRATIVE.

Shipwreck.-Captivity.-Deliverance.-Sidi Ishem.Narrative of Sidi Hamet._Adventures in the Desert. -Tombuctoo.-Wassanah, $\quad$ - $\quad$ - $\quad$ - 488

Appendix to Book I.

Notices of the Expeditions which have sailed to the River Congo and Niger, 


\title{
HISTORICAL ACCOUNT
}

\author{
OF \\ DISCOVERIES AND TRAVELS \\ IN \\ AFRICA.
}

VOL. I. 



\section{INTRODUCIION.}

\section{CHAPTER I.}

DISCOVERIES OF THE ANCIENTS.

Division of the Ancient World into Continents.-Mediterra: nean Coast.-Infuence of poetical ideas._Curiosity of the Ancients respecting the interior.-Attempts to circumnavigate Africa; Phenicians under Necho; Sataspes; Eudoxus.-Voyages along the Western Coast; Hanno; Scylax; Polybius.-Eastern Coast; Evemerus; Arrian's Peri: plus.-Attempts to penetrate into the interior; the Nasamones; Cambyses; Alexander; Roman Expeditions.

IN every age, gifted with any liberal spirit of inquiry, the discovery of regions betore unknown has afforded a favourite gratification to human curiosity. The contemplation of nature under a new aspect,-the view of beings who, while they generally resemble ourselves, exhibit features strikingly dissimilar,-even the perils and adventures through which the discovery is made, kindle always an extraordinary interest. Several expeditions of discovery are mentioned by 
ancient writers, and many more were probably undertaken, of which no records are now in existence. Yet the steps of their progress can by no means be traced with the same precision as those by which the modern world has been explored. Regular narratives, such as have now become so frequent, were either never produced, or have all perished in the wreck of antiquity. The events connected with this progress, are found only in detached notices scattered through the writings of geographers, historians, and even of poets. These have, however, been collected with very great diligence by a series of learned men in modern times, from whose inquiries, compared with the original materials, it may be possible to exhibit such a sketch of the progress of ancient discovery in Africa, as will be gratifying to the curiosity of the general reader.

The first steps of that process by which the old world was divided into continents, are involved in some obscurity. Some curious notices, however, are recorded by Eratosthenes. * The distinction

* Strabo (Xylandri), II. 45. It is true, Strabo himself endeavours to controvert these observations, but, so far as I can discover, on no solid ground, and solely from his general wish to contradict his predecessor. The application to Africa is of my own making; but I think it arises clearly from the precedent of Asia, and from the particular and general uses of the names of Africa and Libya, as noticed in the text. 
began in the islands called Cyclades, the earliest seat of Grecian science. There it was adopted, in order to discriminate between the opposite shores of Greece and of Caria. It appears from Homer, that the latter actually contained a small district called Asia, which, from this singular accident of its position, has given its name to a third part of the habitable globe. As knowledge extended, the name of Asia soon spread over the whole peninsula, of which Caria formed the western extremity. It gradually took a far wider range; yet this peninsula continued to be called Asia Proper, or Asia Minor, which last name it retains to this day. In the same manner, the coast of Libya naturally formed a third continent, which was called Africa, or Southland, expressive of its relative position to Greece. Accordingly, we find here a district, which, down to the twelfth century, was called Africa Proper, and sometimes Africa Minor; to which we may add, that Libya, the native name of this region, is, by the most ancient writers, generally extended to the whole continent. From these three positions, the progress of discovery spread in every direction; and each newly explored region was added to the quarter from which the discoverer had taken his departure. At length the adventurers from different sides met; and at that point, the boundary line of two continents was fixed. The meeting of 
those coming respectively from Europe and from Asia, appears to have been on the banks of the Phasis ; which river, in the age of Herodotus, was supposed to divide these two quarters of the globe. In Africa, the desert which separated Egypt from Libya, formed a bar against discovery; while the fine regions of Syria and Egypt were rapidly traversed. Egypt, therefore, being discovered by Asiatic adventurers, was, in defiance of the clearest natural indications, long considered as part of Asia. Even in the time of Strabo, the Nile was generally viewed as the boundary of the two continents; nor is it till Ptolemy, that we find the natural limits fully assigned, of the Red Sea, and the Isthmus of Stuez.

Meantime, discovery proceeded with greater activity along the western regions of Africa. Objects here presented themselves, which acted powerfully on the exalted and poetical imagination of the ancients. They were particularly struck by those oases, or verdant islands, which reared their heads amid the sandy desert. Hence, doubtless, were drawn those brilliant pictures of the Hesperian gardens, the Fortunate Islands, the Islands of the Blest, which are painted in such glowing colours, and form the gayest part of ancient mythology. The precise position of these celebrated. spots has been a subject of eager and doubtful inquiry. The chief difficulty is, that there are seve- 
iral different points of the continent to which they seem to be fixed, with almost equal precision. In fact, it seems clearly shewn by some learned writers, * that this variety of position is referable, not to any precise geographical data, but to the operation of certain secret propensities, that are deeply lodged in the human breast. There arises involuntarily in the heart of man, a longing after forms of being, fairer and happier than any presented by the world before him-bright scenes, which he seeks and never finds, in the circuit of real existence. But imagination easily creates them in that dim boundary, which separates the known from the unknown world. In the first discoverers of any such region, novelty usually produces an exalted state of the imagination and passions ; under the influence of which, every object is painted in higher colours than those of nature. Nor does the illusion cease, when a fuller examination proves that, in the place thus assigned, no such beings or objects exist. The human heart, while it remains possible, still clings to its fond chimeras. It quickly transfers them to the yet unknown region beyond ; and, when driven from thence, discovers still another more remote, in which they can take refuge. Thus, we find these fairy spots successively

- See Gosselin Geographie Ancienne. Malte Brun Histoire de la Geographie. 
retreating before the progress of discovery, yet finding still, in the farthest advance which ancient knowledge ever made, some remoter extremity to which they could fly.

The first position of the Hesperian gardens appears to have been at the western extremity of $\mathrm{Li}$. bya, then the farthest boundary, upon that side, of ancient knowledge. The spectacle which it often presented, a circuit of blooming verdure amid the desert, was calculated to make a powerful impression on Grecian fancy, and to suggest the idea of quite a terrestrial paradise. It excited also the image of islands, which ever after adhered to these visionary creations. As the first spot became frequented, it was soon stripped of its fabled beauty, So pleasing an idea, however, was not to be easily relinquished. Another place was quickly found for it ; and every traveller, as he discovered a new portion of that fertile and beautiful coast, fondly imagined, that he had at length arrived at the longsought-for Islands of the Blest. At length, when the continent had been sought in vain, they were transferred to the ocean beyond, which the original idea of islands rendered an easy step. Those of the Canaries having never been passed, nor even fully explored, continued always to be the Fortunate Islands, not from any peculiar felicity of soil and climate, but merely because distance and imperfect knowledge left full scope to poetical fancy. 
Hence we find Horace painting their felicity in the most glowing colours, and viewing them as a refuge still left for mortals, from that troubled and imperfect enjoyment, which they were doomed to experience in every other portion of the globe.

It is only by these obscure and evanescent traces, that we discover the progress of the ancients along the northern coast of Africa. At the earliest period of authentic history, the whole of this tract was known to the northern European nations, and formed, as it were, one system along with them. The names of Egypt, of Libya, and of Carthage, are as familiar in classic story, as those of Greece and of Rome. To the south, however, there remained an immense expanse of land and ocean unexplored. The extent of this unknown region, the peculiar aspect of man and nature, the uncertainty as to its form and termination, rivetted upon it, in a peculiar degree, the attention of the ancient world. All the expeditions of discovery on record, with scarcely any exceptions, except those of Nearchus and Pytheas, had Africa for their object. They were undertaken with an anxious wish, first, to explore the extent of its two unknown coasts, those which stretched beyond the Mediterranean on one side, and the Red Sea on the other; to ascertain, above all, the termination to which these led; and next, to penetrate into the depth of that mysterious world in the interior, which, 
guarded by the most awful barriers of nature, inclosed; as with a wall, the fine and fertile shores of northern Africa.

At an era anterior to the earliest records of history, extraordinary efforts appear to have been made to effect the circumnavigation of Africa. The first attempt is that recorded by Herodotus, as having been undertaken by order of Necho king of Egypt. The narrative relates, * that certain Phenician navigators, employed by that enterprising monarch, set sail from the Red Sea into the southern ocean. They continued to navigate along the exterior coast of Africa, till their provisions were exhausted. They then landed, sowed a crop, waited till the harvest was gathered in, and, with this new supply, continued their voyage. In this manner, they spent two years, and part of a third; at the end of which time, they arrived at the Pillars of Hercules, and sailed up the Mediterranean to Egypt. They related, that, in passing round Africa, they had the sun to the right, that is, to the north of their course; a report which Herodotus refuses to believe, but which, to us, who know that such must have been its position, affords the strongest presumption in their favour. This narrative has been the subject of much learned and

* Herodotus, IV. 49 . 
curious discussion. Gosselin * and Vincent + have endeavoure to prove that it is altogether beyond any means which navigation, at that infant era, could call into action. On the other hand, the learned arguments of Major Rennell $\ddagger$ appear to throw upon the relation a very strong aspect of probability. Nor is this much diminished by considering, that the event is entirely unnoticed by many of the most learned writers in subsequent times. Ancient knowledge was of so glimmering and transitory a nature, that it would be easy to multiply instances, in which important facts, consigned in the writings of the best authors, have been lost to the world, during a long succession of ages. $\$$

The memory of this voyage probably gave rise to another, which is also recorded by Herodotus. II Sataspes, a Persian nobleman, having committed an act of violence, was condemned by Xerxes to be crucified. One of his friends persuaded the monarch to commute this sentence into that of $a_{0}$

- Geographie des Anciens, I. 199, 216.

+ Periplus of the Erythrean Sea.

$\ddagger$ Geography of Herodotus, sect. 24, 25 .

\$ Striking examples will be furnished by comparing the geographical information of Herodotus and Strabo, with regard to the course of the Tanais, the nations to the north of the Black Sea, the form of the Caspian, \& $c$.

\|I IV. 43. 
voyage round Africa, which was represented as a still severer punishment. Sataspes, accordingly, having procured a vessel and mariners in the ports of Egypt, set out on this formidable expedition. $\mathrm{He}$ passed the Straits, and sailed along the western coast for several months, which would probably bring him as far as the desert. The view of those frightful and desolate shores, and of the immense ocean which dashed against them, might well intimidate a navigator, bred in the luxurious indolence of the Persian court. Sataspes was struck with panic, and turning the vessel, measured back his way to the Straits. He did not even hesitate to present himself before Xerxes, conceiving, probably, that the series of adventures and sufferings through which he had passed, might obliterate the recollection, both of the crime he had committed, and of the part of his task which he had left unperformed. He stated, that, after having, in defiance of every difficulty, navigated an immense extent of coast, he had arrived at an obstacle (of what nature is not specified) which rendered his further progress altogether impossible. To a monarch like Xerxes, who expected that all nature would obey his fiat, such an excuse was not likely to appear very satisfactory. He considered only that his mandate had been unfulfilled, and ordered the original sentence to be immediately executed. Sataspes 
avoided it by making his escape to Samos. The only particular given of the voyage is, that the inhabitants of the coast were men of small stature, who, whenever they perceived the Persians landing, fled to the mountains, abandoning their cattle and habitations to the mercy of the. strangers.

These attempts to circumnavigate Africa were made with ample means, and under the direction of the most powerful monarchs of the age. The next was by a single, unaided, and even persecuted individual. Eudoxus, * a native of Cyzicus, being sent with the presents of his country to the Corinthian games, touched on his way at Alexandria. Here his geographical science, and unbounded zeal for discovery, recommended him to the notice of Evergetes, who then reigned in Egypt. A plan seems at first to have been formed for exploring the Nile in the higher parts of its course. While this was under discussion, however, there was brought to Alexandria a native of India, who had been shipwrecked near the foot of the Arabian gulf. This personage undertook to become a guide in shewing the naval route to India. Such an expedition entirely suited the genius and views of Eudoxus; and he was accordingly appointed to the chief command. He returned la-

* Strabo, II. 67, 68. 
den with wealth ; of the greater part of which he complains that the king had stripped him. However, a new expedition was fitted out for the same destination. In this voyage the wind droye him upon the eastern coast of Africa, where he landed at several points, carried on some trade, and held considerable intercourse with the natives. A desire to perform the circuit of that continent seems here to have seized his mind, and to have become ever after its ruling passion. It so happened, that he found here the remnant of a wreck, said to have come from the westward, and which consisted merely of the point of a prow, on which a horse was carved. Other passions besides jealousy, when they engross the whole soul, convert "trifles light as air" into " confirmations strong." This prow, being carried to Alexandria, and shewn to some natives of Cadiz, was declared by them to resemble exceedingly those attached to a particu. lar species of fishing vessels, which frequently resorted to the coast of Mauritania ; and they added, that some of these vessels had actually gone to the westward, and never returned. All doubt seemed now at an end; and Eudoxus thought only of effecting this grand expedition. Conceiving himself injured by Cleopatra, who had now succeeded Evergetes, he determined no longer to rely on the patronage of courts, but repaired to Cadiz, a great commercial city, where the prospect of a 
new and unobstructed route to India could not fail to excite the highest interest. On his way from Alexandria he passed by Marseilles, and a number of the other maritime states, where he loudly announced his intention, and invited all who were animated by any spirit of enterprise to take a share in its execution. $\mathrm{He}$ accordingly succeeded in fitting out an expedition on a very large scale, and equipped almost with regal pomp. He had one large and two small vessels; on board of which were embarked, not only provisions and merchandize, but medical men, persons skilled in various arts, and even a large band of musicians. A crew composed chiefly of volunteers, full, doubtless, of extravagant hopes, were not likely to submit to regular discipline, or to endure cheerfully the hardships of such a voyage. They soon became fatigued with navigating in the open sea, and insisted that Eudoxus should draw near to the coast. Here the event happened, which that navigator had foreseen. The ships struck upon a sand-bank, and could not be got off. The cargo, however, and even part of the timber belonging to them, were brought on shore; and, from their materials, a new vessel was constructed on a smaller scale, with which Eudoxus resumed his voyage. He soon after came to nations, speaking, as he fancied, the same language with those whom he had seen on the eastern coast. The smallness of 
his vessel rendered it impossible to proceed farther. On his return, he applied to Bocchus, king of Mauritania, and endeavoured to inspire that barbarian with his own zeal for maritime discovery. He appeared to have succeeded, and orders were given to equip an expedition; but Eudoxus was privately assured, that the mind of the king had been poisoned against him, and that the mariners were privately instructed to abandon him on an uninhabited island. This report, true or false, induced him to make his escape from Mauritania. His next recourse was to Iberia, where he actually succeeded in equipping an expedition as considerable as his first one, and better calculated for the voyage. It consisted of one vessel, adapted for navigating in the open sea; and another for reconnoitring the coast. They were provided also with seed and labouring utensils, in the view of raising a harvest on the voyage, in the manner reported to have been done by the Phenicians. At this point, unfortunately, the narrative of Strabo stops short, and leaves us totally in the dark as to the result of this new expedition. It is true, Cornelius Nepos is said to have asserted, * that Eudoxus actually did make the circuit of Africa, but having stated his departure as from the Red Sea, could not have had in view the voyage in 
question. Mela has added some particulars, but of the most fabulous complexion, respecting the nations whom he saw along the coast. One was dumb; another wholly without a tongue; while a third had the mouth entirely closed, and received food through an orifice in the nose. No such marvels occur in the narrative of Strabo, which, we agree with a late learned writer.* in thinking, may probably be regarded as authentic. It exhibits a man rash, enthusiastic, and somewhat empirical, yet possessed of that boldness, enterprise, and perseverance, which could alone promise success in such arduous undertakings.

These are all the instances recorded, in which the complete circumnavigation of Africa was either performed or attempted. Other voyages, however, were undertaken, with a view to the exploration of a certain extent of its unknown coasts. The most ancient and most memorable is that of Hanno, sent out, at a very early period, by a state which surpassed, in commerce and power, all others on the African coast. $f$ The Carthaginians fitted out this expedition, with a view partly to coloniza. tion, and partly to discovery. The armament consisted of sixty large vessels, on board of which

* Malte Brun, Histoire de la Geographie, 162.

+ Geog. Græc. Minores, Vol. I.

VOL. $x$. 
were embarked persons, of both sexes, to the number of 30,000 . The narrative begins at the passage of the Straits, or Pillars of Hercules. After two days sail from thence, they founded, in the midst of an extensive plain, the city of Thymiaterium. In two days more they came to a cape, shaded with trees, called Solocis, or the promontory of Libya, on which they erected a temple to Neptune. 'They sailed round a bay, thickly bordered with plantations of reeds, and where numerous elephants and other wild animals were feeding. On emerging from it, they founded succes. sively other four cities. Their next course was to the great river Lixus, flowing from Libya and from high mountains behind, which were filled with wild beasts, and inhabited by a race of inhospitable Ethiopians, who lived in caves, and surpassed even the wild animals in swiftness. Proceeding then three days along a desert coast, they came to a small island, situated in a deep recess of the sea, to which they gave the name of Cerne, and where they founded a colony. They now entered another bay, and passing over a great extent of coast, found several islands and rivers, particularly one very large, filled with crocodiles and hippopotami. Returning to Cerne, they sailed southwards along the coast of the Ethiopians, a timid race, who fled at their approach. After passing a wooded promontory, they came to a gulf, in which were several large islands. Here a re- 
markable phenomenon arrested their attention. During the day, a profound silence reigned, and nothing appeared but a vast world of wood. But when night arrived, the shore blazed with fire, and echoed with tumultuous shouts, and with the sound of cymbals, trumpets, and musical instruments of every description. The Carthaginians, appalled, passed hastily along these shores, and came to another region, which struck them with no less surprise. Here the land appeared all on a blaze; torrents of fire rushed into the sea; and if they attempted to land, the soil was too hot for the foot to tread upon. One object particularly struck them, which, at night, appeared a greater fire, mingling with the stars; but, in the daytime, proved to be a mountain of prodigious height, to which they gave the appellation of the Chariot of the Gods. After sailing three days, they lost sight of these fiery torrents, and entered another bay, containing an island, which presented a new phenomenon. The inhabitants were of human form, but, shagged and covered with hair, suggested the idea of those grotesque deities, by which superstition supposed the woods to be peopled. To these monsters they gave the name of Gorillæ. The males evaded all pursuit, as they climbed precipices, and threw stones on their pursuers; but three females were caught, and their skins carried to Carthage, Here the narrative stops by saying, 
that the farther progress of the expedition was arrested by the want of provisions.

Such are the leading features of this celebrated voyage, than which none has afforded, in modern times, more ample room for the speculations of the learned. Many of the circumstances, which wore at first a marvellous aspect, have been found to correspond with the observations of modern travellers. The fires and nocturnal symphonies represent the habits prevalent in all the negro states; repose during the day, music and dancing prolonged through the night. The flames, which seemed to sweep over an expanse of territory, might be occasioned by the practice, equally general, of setting fire, at a certain season of the year, to the grass and shrubs; and the Gorillae were evidently that remarkable species of ape to which we give the name of oran-outang. Extreme difference of opinion prevails, however, as to the extent: of the coast traversed, and the objects to which the different respective parts of the descrip- tion apply. According to Major Rennell, the island of Cerne is Arguin, the great river is the Senegal, the islands are the archipelago of the Bissagos, and the whole voyage reached a little beyond Sierra Leone. * M. Grosselin, on the contrary, contends, that the whole course was along the

* Geography of Herodotus, Sect. 16-26. 
coast. of Morocco; the Lixus was the modern Lucos, Cerne was Fedala, and the whole voyage: extended little beyond the river of Nun. * Those who wish to see how far learning and ingenuity. can be carried upon such a subject, will find much gratification in perusing the respective treatises of these yery learned and eminent writers. It is certain, that the whole aspect of man and nature, as observed by Hanno, seems exactly that which now? presents itself on the banks of the Gambia and Senegal. Morocco, indeed, in its native and unsubdued state, must have been much more nearly in the same situation than now; yet there seems some difficulty in supposing the resemblance to have been so very complete. Some of the details, however, particularly those relating to the river Lixus, support M. Gasselin's hypothesis so very. strongly, that, after much hesitation, we rather incline to concur in it.

It does not appear that the Greeks and Romans ever sailed much along this exterior coast of Africa. There exists, however, another document of some importance, called the Periplus of Scylax. $t$ This work consists, not of the narrative of any particular voyage, but of a description, collected probably from various sources, of all the

* Geographie des Anciens, I. 61-164.

+ Geog. Graec. Minores, Vol. I. 
shores of the then known world. His representation of the western coast agrees nearly with that of Hanno, except that it reaches no farther than Cerne; beyond which, he asserts that the accumulation of mud and sea-weed renders navigation impossible. Here the Phenicians carried on trade with the Ethiopians, a race who exceeded all other men in stature, and even chose their kings on account of that quality of body. Ivory was the chief object of trade, and was here so abundant, that the natives made it into cups, and employed it in adorning, not themselves only, but even their: horses. They abounded in horses and cattle; lived chiefly on Alesh and milk, and made, as well as imported, a great deal of wine. Other imports were Egyptian unguent, Athenian cloths, and various domestic utensils. It was reported by some, that the coast, from this point, reached across in a direct line towards Egypt, and that Africa thus formed a peninsula, of which the greatest length was from east to west.

This coast, at a much later period, excited the curiosity of the Roman conquerors. Polybius, the celebrated historian, was sent by Scipio to make an exploratory voyage in this direction. It is much to be regretted, that we should possess no record of an expedition made by so able and judicious an observer. Pliny has preserved only a very meagre itinerary, from which, however, 
Gosselin seems to have justly inferred, that the Roman explorer did not sail quite so far as the Carthaginian had done.

Curiosity and commerce attracted also the attention of the ancients towards the eastern coast of Africa. The first voyages which can be referred to that region, are those to Tarshish and Ophir, mentioned in the sacred writings. They were sent by the Jewish monarchs, at the greatest height of their power, and when aided by Tyre, the first maritime state of antiquity. Several very learned writers seem now inclined to confine these voyages within the limits of the Arabian gulf. But I confess, that the voyage of three years, the exclusive produce of gold and ivory, (with the trifling addition of apes, ) even the name of Ophir (Soopheira, Septuag.) strongly suggest a considerable progress along the shore of the Indian ocean. It is true, that such a communication, and all knowledge of it, were entirely lost ; and in the time of Alexander, navigation did not extend beyond Cape Guardafui. But we have already noticed the perishable nature of all geographical knowledge among the ancients. After the death of Solomon, and the dissolution of the alliance with Tyre, this great branch of commerce was lost; and all attempts to restore it proved abortive, *

I. Kings, xxii. 48. II. Chronicles, xx. 36-38. 
Nor did any active and commercial power again obtain a footing upon this sea. Discontinued thus for several ages, we may easily suppose the recollection of it to have been entirely lost.

The Greeks, whom no report of the existence of Tarshish and Ophir seems ever to have reached, were thus left entirely to their own efforts for exploring the east of Africa. The first narrative of a voyage thither is indistinct, and rests even under strong imputations of fable. Evemerus, a Messenian, sent by Cassander, king of Macedonia, is said to have discovered, opposite to the southern coast of Arabia Felix, three islands, which bore the general name of Panchæa. They consisted of one very large, with two smaller, which lay to the east; and from the farthest of which India was described like a cloud in the distant sky. The territory yielded myirh and frankincense in such extraordinary abundance, that the whole world was thence supplied with these fragrant aromatics. A profusion of the most beautiful trees and shrubs, with every thing which can minister to use or beauty, is said to have rendered this region completely a paradise. The government was that of a limited monarchy, where great power was vested in the people, and the priests were held in extraordinary veneration. * The ge-

* Diodorus, V. 42 . 
neral yoice of antiquity is against Evemerus, as it is also against Pytheas and Eudoxus. But $\mathrm{I}$ believe the scepticism which has attached to the first explorers of any region, has usually proved to be excessive and illiberal, and to have arisen chiefly from the limited views of those to whom the report was addressed. The position opposite to Southern Arabia, and the profusion of myrrh and incense, strongly suggest the coast of Africa, west of Cape Guardafui. To one who sailed across from Arabia, this coast might very readily appear to be that of an island. The distinction, indeed, between continents and islands, presented always one of the tasks most difficult to be performed by infant geography.

From the notice which we have already given of the voyages of Eudoxus, it appears that he sailed along some part of the eastern coast, bordering on the Indian ocean. From that time a progressive series of discovery was doubtless carried on from Alexandria ; but no record of it is preserved, unless in a work, entitled the Periplus of the Erythrean Sea, published probably somewhat posterior to the age of Pliny. It appears to be less the narrative of an actual voyage, than a descriptive guide for the use of the merchants who traded along the coasts of Africa and India. They set sail from Myos Hormos (near Cosseir), and after passing Berenice (Belled-el Habbesh), came to Ptole- 
mais Therôn (a promontory in N. lat. $17^{\circ} 6^{\prime}$ ), which derived its name from being much resorted to by the royal hunters. The next port was Adulis, the great emporium of this region, and situated near the modern Massuah, which still carries on all the foreign trade of Abyssinia. The chief commodity consisted in a great quantity of very excellent ivory, brought from Coloe, situated three days journey in the interior. Five days journey beyond was the metropolis Axum, of which there still remain very magnificent ruins. Leaving Adulis, they came to a region, governed by a prince called Zoskales, who is the subject of very warm panegyric ; represented as brave, generous, and deeply versant in Grecian learning. The exports here continued to be chiefly ivory and rhinoceros' horns : the imports very various ; manufactures of cloth, iron, and brass ; a little wine and oil ; and some gold and silver ornaments, as presents to the king. The vessels then passed the Straits, and entered the gulf of Avalites. From this coast, as far as Cape Aromata (Guardafui), the exports were myrrh, frankincense, cassia, and various other aromatics; also a small quantity of ivory and tortoise-shell. After passing Cape Guardafui, the voyage lay along the barren coast of Azania (Ajan). The navigator then came to a succession of harbours, each at the mouth of a river, and at about a day's sail from the other; 
supposed by Dr Vincent to be the estuaries of the great river Quillimanci. There occurred next a low and wooded island, called by the very extraordinary name of Eitenediommenouthesias (probably Zanzibar). Two days farther sail brought them to Rhapta, * the farthest port then known, and the great emporium of Azania. This region was then governed by a king called Mopharites; of Arabian origin, and himself tributary to the inhabitants of Musa, who claimed a species of monopoly of the trade of Rhapta. The exports here were ivery in great quantity, but not equal in quality to that of Adulis ; also rhinoceros' horns and tortoise-shell, the best in all Africa. The imports were chiefly arms, for the use of this barbarous people, with corn and wine, not so much for regular trade as by way of presents, to secure their willingness to continue the communication.

The author of the Periplus knew nothing of the coast beyond Rhapta, but believed that it continued to extend westward, till it joined the Atlantic ocean. Marinus, the Tyrian geographer, collected the reports of some navigators, who had sailed a considerable distance farther, to Prasum ; on which a promontory, a city, and harbour were built. After passing Rhapta, the coast changed its direction from south-west to south-east, which last it retained as

* Quiloa, according to Dr Vincent. 
far as Prasum; and, as Marinus believed, much farther, till it joined the eastern coast of Asia.

M. Gosselin has endeavoured to prove, that the ancient Rhapta was situated at the mouth of the Doara, and that Prasum was the modern Brava; * thus allowing only a very limited navigation along: the eastern coast. But there seems room for preferring Dr Vincent's exposition, from two circumstances ; first, the succession of estuaries, described in the Periplus, which can be found nowhere till the point assigned by that author; next, the change of direction in the coast, from south-west to south-east; which nothing within M. Gosselin's limits seems at all likely to have suggested. $f$ I should not be inclined, however, to extend Prasum beyond Cape Delgado; after which the eastern direction of the coast would no longer exist. The total omission of the mention of gold, seems to forbid the idea of any approach towards Sofala.

It remains only to consider the attempts made to explore the interior of the African continent. This region, to the ancient world, inspired always

* Geographie Ancienne, I. 188, \&c.

+ Mr Salt remarks the mouth of the Doara, as the point where the direction of the coast changed from almost due south to south-rvest, which makes it very improbable that the navigators should here have supposed that they werc changing from west to east. 
emotions of wonder and curiosity, mingled with terror. It was the region of mystery, of poetry, of superstitious awe. The wild and strange aspect of man and nature, the immense tracts abandoned to wild beasts, the still more immeasurable deserts of sand beyond, and the destruction which had overwhelmed most of thase who attempted to penetrate; all these formed, as it were, a fearful and mysterious barrier, drawn round the narrow limits occupied by the civilized nations of this continent. -Every object which appeared through the veil tended to heighten this impression-the human race, under an aspect and hue nowhere else seen on the globe ; animals of strange form and magnitude; forms of society altogether uncouth and peculiar. Imagination, kept always on the stretch, created wonders, even when nature ceased to pre-sent them. No part of the interior was ever explored with such precision, as to deprive that active faculty of full scope for exertion; and the whole region was in a manner given up to fable. This fable, however, had generally some basis of truth; and it cannot be without interest to observe the glimpses which the ancients obtained, whenever, for a moment, they succeeded in lifting the veil, by which those vast regions were covered.

All the nations who inhabited within or beyond the desert were generally known by the name of Ethiopians. The term becomes thus nearly syno- 
nymous with that of Negro, though it does not always imply complete blackness of complexion; Ptolemy and Pliny even distinguish a race by the name of White Ethiopians. The tract, however, which was particularly considered as the kingdom of Ethiopia, was that which lay " under Egypt," by which was meant Nubia, with part of Abyssinia. This kingdom, with its capital, Meroe, was chiefly known by the formidable irruptions made thence into Egypt, which repeatedly subjected that country to Ethiopian dynasties. Diodorus represents them as the most ancient of nations, and their country as the cradle of civilization, adding, that Egypt was indebted to them for its boasted science. But, according to Herodotus, an earlier and higher authority, all the civilization which Ethiopia ever possessed was introduced by colonists from Egypt. It is a more probable report, that many of the objects of ancient worship were drawn from this region, whose mysterious remoteness naturally tended to inspire sentiments favourable to the growth of superstition.

The first journey into the interior, undertaken for the purpose of discovery, is that remarkable one which Herodotus * records as performed by some young Nasamonians. This people occupied a district of northern Africa, lying to the west of 
Cyrene, and forming part of the modern Tripoli. Five young men, sons of the principal citizens, were seized with an ardent desire to explore Africa, beyond the farthest limit to which discovery had hitherto reached. They traversed first, without difficulty, the cultivated tracts of Libya; then passed safely also through the region inhabited by wild beasts, and came to the great desert of sand. Being well stored with provisions and water, they also entered this tract, and traversed it for many days in a westerly direction; after which they came to a plain, diversified with a few trees. These being a novel object, they began to pluck and eat the fruit with peculiar relish, when they were surprised by a body of men, black, and of small stature, who immediately made them prisoners. These men carried them through very extensive marshes or lakes, to a city inhabited by a people similar to themselves. This city was traversed by a great river flowing from west to east, and in which crocodiles were found. From all these circumstances; Major Rennel infers, that the city must have been one situated in central Africa, and the river which traversed it the Niger. The only character given of the inhabitants is, that they were impostors or sorcerers, a description agreeing sufficiently with the superstitious habits to which the Negroes are generally addicted.

The next attempts of which we find any record, 
are the two expeditions of Cambyses to the south and west of Egypt. * Although conquest was doubtless their primary object, yet a considerable share of wild curiosity seems to have mingled in these desperate undertakings. Cambyses divided his army into two parts, one of which he led in person against the southern Ethiopians, while he sent the other against the Ammonians (inhabitants of the modern oasis of Siwah). . He himself, taking the command of the former, set out from Thebes, and proceeded for some time in full confidence of success. The army had not 'gone far, however, when their whole stock of provisions was exhausted. Support was afforded, first by killing all the cattle that belonged to the expedition, then by feeding on the scanty herbage which the ground afforded. Still the proud obstinacy of Cambyses, who conceived that all nature ought to be subservient to him, repelled the mortifying idea of renouncing his project. At length they came to the region of pure sand, when all food whatever failed, and the troops had recourse to the desperate extremity of devouring each other. Cambyses, struck at length with just horror, desisted, and returned to Thebes, but not till he had lost a large proportion of his army. Of the other expedition, which had gone against the Ammonians, the fate remained for ever buried 
in impenetrable mystery. It could only be known, that it never either reached Ammon, or returned to Egypt. It was hence inferred, that the whole must have found a grave in the vast ocean of sand which intervened. These examples proved an awful beacon to future conquerors and explorers; they heightened the mingled sentiment of veneration and terror with which these interior abodes were contemplated. This desert seemed as a barrier fixed by nature, which she would never permit any mortal to pass with impunity. These regions remained, therefore, undisturbed till the arrival of a new conqueror, who was not wont to be deterred by any common obstacles. Alexander, * when the career of conquest carried him to Memphis, determined to proceed, and visit the temple of Jupiter Ammon. With the frantic wish of being owned as the offspring of that Deity, was probably mingled a romantic curiosity to behold the mysteries that were hid in the depth of these awful solitudes. He viewed himself probably as a darling of fate, over whom the perils that over. whelm the rest of mankind would lose their influence. The army, however, suffered immensely during this march; and, but for a seasonable shower, the consequences might have been fatal. At length, they beheld with astonishment, in the

* Curtius, IV. 7 .

VOL. I. 
heart of this immense desert, a spot covered with luxuriant verdure, flowing rivulets, and all the beauties of perpetual spring. The king then sought the most aged of the interpreters of the oricle, and inquired his own origin and destiny. The spears of the invincible phalanx, drawn up in battle array, threw a wonderful light on the eyes of the prophet. He at once saw and owned Alexander as the son of Jupiter, and worthy of divine honours; a declaration with which the monarch departed better satisfied than some of his followers.

Under the liberal and enlightened administration of the Ptolemies, it cannot be doubted, that great efforts would be made to extend the knowledge of interior Africa. The same may probably be said of the Romans, whose writers evidently show that their countrymen felt on this subject the same mixture of wonder and curiosity, which animated the natives of Egypt and Greece. The fruit of this spirit of inquiry appears in the extended knowledge of the geographical writers of the first and second centuries. Of the steps, however, by which this knowledge was procured, no record is to be found, with the exception of a short and incidental notice by Ptolemy,* of two Roman expeditions. The one was made by Septimius 
Flaccus, who, marching directly south from Garama, came in three months to the country of the Ethiopians; the other by Julius Maternus, who, on learning that the Ethiopians had attacked Garama, marched in four months from Leptis Magna to Agisymba, a country inhabited by that people. These two generals, therefore, crossed the desert; but no details are given of their march, or of the region with which it terminated. Ptolemy even expresses some doubts as to its possibility; which, however, evidently arise only from his own imperfect knowledge as to the extent of this part of the continent. 


\section{CHAPTER II.}

DISCOVERIES DURING THE MIDDLE AGES.

The Arabians.-Their Entrance into Africa; their Establishment on the Niger.-Kingdoms of Ghana, Wangara, \&.c.-Limits of their Knowledge._Leo Africanus._Changes in Central Africa.-Foundation of Tombuctoo.-Description of that City._Ghinea.-Melli._Gualata.

THE rise of the Mahometan power, and the vast hordes of Saracen invaders which poured into A. frica, caused a complete revolution in the moral - and political aspect of that continent. This revolution, of which the ultimate effect was to extinguish all the intelligence, activity, and civilization, by which it had been illustrated, showed at first a completely opposite tendency. The Caliphate was held, during several ages, by a race of monarchs who rank among the most accomplished by whom any throne has been swayed; the arts of peace were perfected even in the bosom of war, and the nations placed under their rule, cherished almost alone the lights of science, which were fast expiring in every other region. The migratory spirit of this 
celebrated people, their commercial habits, their zeal in the pursuit of geographical science, all impelled them to direct their steps into the yet unknown regions of interior Africa. The desert, that barrier which deterred all former approach, appeared far less formidable to an Arabian explorer. It recalled to him the image of his native country, where he had long been familiar with every expedient, by which such an expanse could be traversed in safety. The camel, transported into a congenial soil, afforded the means not only of effecting a passage once for the purpose of discovery, but of establishing a regular and constant communication across it. The first route appears to have been from Fezzan, by way of Agades, being the one still followed by the Cassina caravan. The passage is less difficult at this than at any other point ; the immense breadth of the desert being broken by the large oases of Fezzan and Agades, and by several others of lesser magnitude. After passing it, they found a shore, whose fertility and beauty were probably much heightened in their view by the length of the dreary approach to it. But the eyes of this commercial people were peculiarly attracted by a commodity, which, precious in itself, has always been much overrated in the opinion of mankind. From the regions immediately to the south was brought in abundance gold, not disguised in chemical combinations, which could. 
be dissolved only by genius and labour; but already pure, and separated, by a simple mechanical process, from the sand with which it was mingled. A splendour, partly real, and partly imaginary, was thus thrown around this region, which, in the unsettled state of northern Africa, attracted numerous colonists towards it. Compulsory exile has always been a powerful instrument in peopling the globe. Those who fled before the arms of the Saracens, and those who were worsted in the intestine divisions which shook the Caliphate, alike sought refuge and settlements in the depth of the interior. The precise period of these emigrations cannot be distinctly traced ; but it is unquestionable, that, by the tenth or eleventh century, the banks of the Niger were covered with kingdoms, in which Mahomedans formed a numerous, and the ruling part of the population. Of these kingdoms, according to the unanimous testimony of the Arabian writers, the most powerful and splendid was Ghana, situated on the eastern part of the great central river called by them the Nile of the Negroes. The sovereign was absolute within his own territories, and owed homage only to the head of the Abbassides. The pomp of his court was the admiration of the ane ; and appears certainly to have been accompanied with a degree of art and civilization, which scarcely any other negro kingdom has yet attained. The palace, built on the banks of the river, besides 
being of a peculiarly solid structure, and having the luxury, little known in those regions, of glass windows, was adorned with elaborate works of painting and sculpture. Tamed elephants and camelopardales are mentioned as among the accompaniments which swelled the pomp of the sovereign's equipage. 'The circumstance, however, which was considered as distinguishing him above all other African potentates, was a mass of native gold, weighing thirty pounds, which formed the ornament of his throne. Notwithstanding this splendour of the court, the nation in general appears to have been characterized by simplicity, and even by rudeness. The common people wore merely a girdle, composed frequently of the skins of wild beasts ; and it was considered as indicating a superior rank to have any farther covering.

To the sovereign of Ghana was also subject Wangara, or the land of gold, considered probably as the brightest jewel in his crown. The gold here, as over all the rest of.Africa, is represented as entirely alluvial, and found chiefty in the beds of the rivers, or inundated ground after the water has retired. Wangara is represented as formed into a species of island, by branches of the Nile which surround it on all sides; and which, overflowing during the rainy season, lay nearly the whole country under water. As soon as the inundation subsides, the inhabitants are described as rushing with 
eagerness, and digging up the earth, in every part of which they find a greater or less quantity of gold. Immediately after, arrive the merchants from every part of Africa, to exchange their various commodities against this single one. The principal cities of Wangara were Reghebil and Semegonda, both handsome, and situated on the shore of large fresh water lakes.

To the west of Ghana lay the kingdom of Tocrur, including the capital city of the same name, with those of Sala and Berissa. The monarch is said to have been also very powerful, and his dominions the seat of an extensive commerce; but in both these particulars yielding to Ghana. This kingdom was also traversed by the Nile of the Negroes, which, after flowing sixteen days journey westward from Tocrur and Sala, fell into the sea, or more probably into a large lake. At some distance from its shore was found the island of Ulil, which afiorded salt so abundantly as to supply all the states of Nigritia; those states being then, as now, wholly destitute of that necessary of life. To the south of all these countries lay the extensive region of Lamlam (supposed the Melli of Leo). Great part of it was a desert; the rest inhabited by people who were little removed from savages. This tract afforded to the people on the Niger a theatre for the barbarous practice of slave hunting. Inroads were habitually made for that sole pur. 
pose ; and the victims procured became an article of traffic with Northern Africa. There is reason to suspect, that the same practice continues undiminished over all this part of the continent. Edrisi was not acquainted with any inhabited regions to the south of Lamlam, and doubts even if any such existed.

The empire of Bornou is not mentioned in the Arabian writers by that name ; but different portions of it appear evidently to be described under the appellations of Zaghara, Kanem, and Kuku. * Of these Kuku appears to have been decidedly the most powerful and splendid. The king kept a numerous army very finely equipped : and the splendour of his court eclipsed every thing in that part of Africa. The lower orders, as usual in Negro states, were very indifferently clothed; but the merchants, who were numerous, wore vests, tunics, caps on their heads, and ornaments of gold. The nobility are said to have been clothed in sattin. The capital city of the same name was celebrated among the negroes for its extraordinary magnitude.

As the Arabs extended themselves westward

* My reasons for including Kuku in Bornou, and even considering it as the principal part of that empire, will be explained when treating of the geographical system of the Arabjans. 
through Barbary, they opened always new routes across the desert; and when Morocco became the seat of their principal power, Segelmessa was in consequence the emporium of the commerce of $\mathrm{Ni}$ gritia. Another territory called Vareclan, situated apparently to the south of Morocco, carried on a very extensive trade; and its merchants went as far as Wangara in search of gold. The only parts of the interior on which the Arabs made no impression were Nubia and Abyssinia. These countries in the twelfth and thirteenth centuries continued still Christian, and were, therefore, in a state of habitual enmity with the Saracen powers. Only, the necessities of trade produced a species of truce on the frontiers of Egypt and Nubia. The merchants of the respective nations met near the cataracts of Syene, and made an exchange of their respective commodities, without entering each other's territories. *

Between the narrative of the Arabian geographers, and the discoveries of modern travellers and navigators, the link is formed by a celebrated description of Africa, written by a person bearing the appellation of Leo Africanus. $\mathrm{He}$ was born at

* Geographia Nubiensis.-Hartmann's Edrisi. Ibn-alVardi, et Bakui in Notices des Manuscrits du Roi de France. 
Grenada; but, when that city was besieged and taken by Ferdinand, sought refuge in $\mathrm{Fez}$, and devoted himself wholly to Arabic literature. Partly as a traveller, and partly as an ambassador, he traversed a great part of Africa, and composed, in Arabic, the description of that continent, which still renders his name celebrated. Lastly, being taken prisoner, and brought to Rome, he attracted the notice of Leo $\mathrm{X}$. who proved himself the patron of every liberal art and science. Under the auspices of this pontiff, Leo made a translation of his work into Italian, which has been reprinted by Ramusio in his Collection of Voyages. * Having been an eye-witness to most of the scenes which he describes, his work forms the only original authority for the state of northern and central Africa during the period at which he wrote. Where personal observation failed, he unfortunately had recourse to very blundering and erroneous compilation. The coincidence, however, in many respects, of his report with the best modern information, leaves no doubt as to its original character; so that it throws an important light, both on the progress of knowledge, and the changes in the political aspect of this continent.

It appears, that, in the interval between the

* There is also a Latin translation, and one in English, which forms the sixth book in Purchas's collection. 
Arabian writers and Leo, some very important changes had taken place. Ghana, mentioned under the name of Cano, no longer held the supremacy among the states on the Niger, but had become subject to the kingdom of 'Tombuctoo. Wangara, called Guangara, had become an independent kingdom, the sovereign of which maintained a considerable army. The gold, for which this region is so celebrated, is represented by Leo as found, not within itself, but in mountains to the south. Bornou is described under its modern name, also Cassina, under the name of Casena, though it does not appear to have then occupied that high place among the African states which it afterwards attained. But the most remarkable change is the foundation of the kingdom of Tombuctoo, called here 'Tombuto, which took place in the year of the Hegira 610 (A. D. 1215.) Ischia, one of its early sovereigns, appears to have been a most warlike and powerful monarch, and had subjected and rendered tributary all the surrounding: kingdoms, among which were Ghinea, or Genni, Melli, Casena, Guber, Zanfara, and Cano. 'The city itself does not appear to have been very splendid. The houses were built in the form of bells; the walls of stakes or hurdles, plastered over with clay, and the roofs of reeds interwoven together. One mosque, however, and the royal palace, were built of stone; the latter by an artist brought from 
Granada. Cotton cloth was woven in great quantity. The merchants were extremely rich; and the king had married his daughters to two of their number. The inhabitants were copiously supplied with water; that of the Niger, whenever it overflowed, being conveyed into it by sluices. The country round abounded with corn, cattle, and all the necessaries of life, except salt, which was brought from Tegazza, situated at a distance of 500 miles; which was held so valuable, that Leo had seen a camel's load sold for 80 ducats. The king had a splendid court, and many ornaments of gold, some of which weighed 1300 ounces. He maintained also 3000 horsemen, and a numerous infantry; many of whom were in the habit of using poisoned arrows. Horses were not bred, but imported from Barbary, and eagerly sought aftel ; so that the king, whenever any number arrived, insisted on making a selection for himself, paying, however, a handsome price. Manuscripts are particularly mentioned, not only as one of the imports from Barbary, but as bringing more money than any other commodity. The inhabitants were mild and gentle, and spent a great part of the night in singing and dancing. The town was extremely exposed to fire, and our author had known half of it consumed in the space of five hours. The religion was Mahometan; but the intolerance, so strongly reported in modern times, 
is mentioned only in regard to the Jews, who are said to have been most rigorously exclúded.

Cabra was a town similarly built, but smaller. It was situated on the Niger, at twelve miles from Tombuctoo, and was the port from whence the merchants sailed for the western countries of Ghinea and Melli. Ghinea, or Genni, is described as an extensive country, 500 miles in length, and 250 in breadth, extending along the Niger till that river fell into the ocean. The country was very fertile, particularly in cotton; the manufacture of which formed the main staple of its trade. During the months of July, August, and September, it is completely overflowed by the branches of the Niger, which surround it in the manner of an island. At that time the merchants of Tombuctoo conveyed their commodities in small canoes made of a single tree. These they rowed during the day; then fastening them to the shore, spent the night on land. At the time Leo wrote, this country also had been conquered by Izchia, king of Tombuctoo. To the south of it lay Melli, upon a river which fell into the Niger. It is described as also fertile, abounding in merchants and artificers, who enjoyed a great degree of opulence. The inhabitants were the first who had embraced the religion of Mahomet, and were superior to all other negroes in wit, civility, and industry. To the north of Ghinea was Gualata, 
probably Walet, which is represented to have been at one time the centre of the Mahometan power in Africa, and the chief resort of the Barbary merchants. But after the foundation of Tombuctoo, the happier situation of that city enabled it to carry off all this trade, and Gualata ended, like all the neighbouring kingdoms, in becoming tributary to Izchia. 


\title{
BOOK I.
}

\section{DISCOVERIES AND TRAVELS IN THE INTERIOR}

\author{
OF AFRICA.
}

\section{CHAPTER I.}

DISCOVERIES OF THE PORTUGUESE, AND TRAVELS IN CONGO.

Early Voyages along the Western Coast._Prester John.Establishment at Arguin.-Expedition to the Senegal.Early Accounts of Tombuctoo and Jenné.-Discovery of, and Voyage up the Congo, by Diego Cam.-Conversion of the Monarch to Christianity.-Missions to the Upper Part of the Congo.-Batta_Pango._Sundi._Esseno._Concobella._Mission to Matamba; Zingha.-To Maopongo.Voyage of Carli._Of Merolla._Of Battel.-De Grandpré's Account of the present State of Congo.-Descriptions, by various Authors, of the Origin and Course of the Congo.

THE spirit of discovery, and of maritime enterprise, which had lain dormant in Europe during the long series of the middle ages, burst forth, in the fifteenth century, with an energy almost un- 


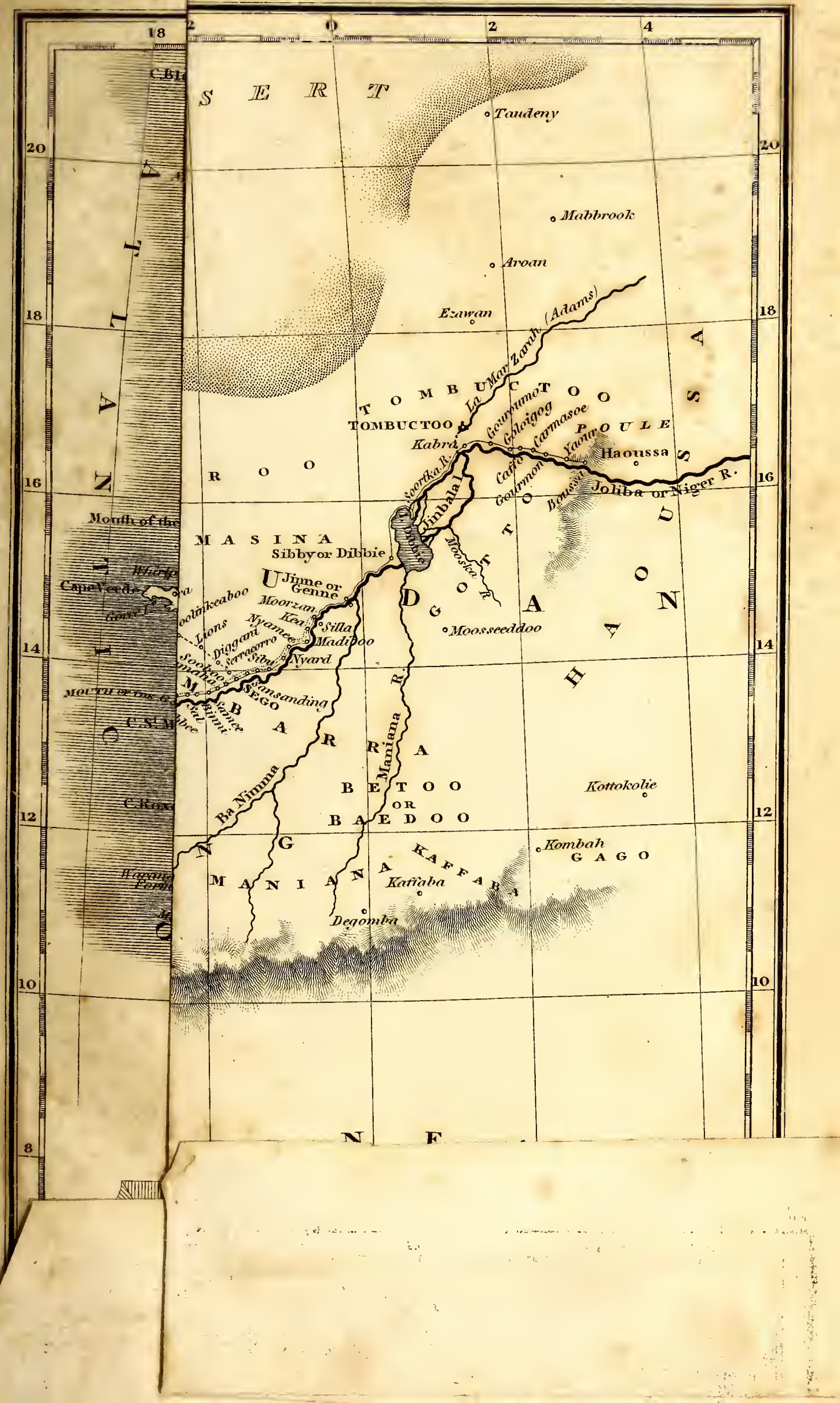





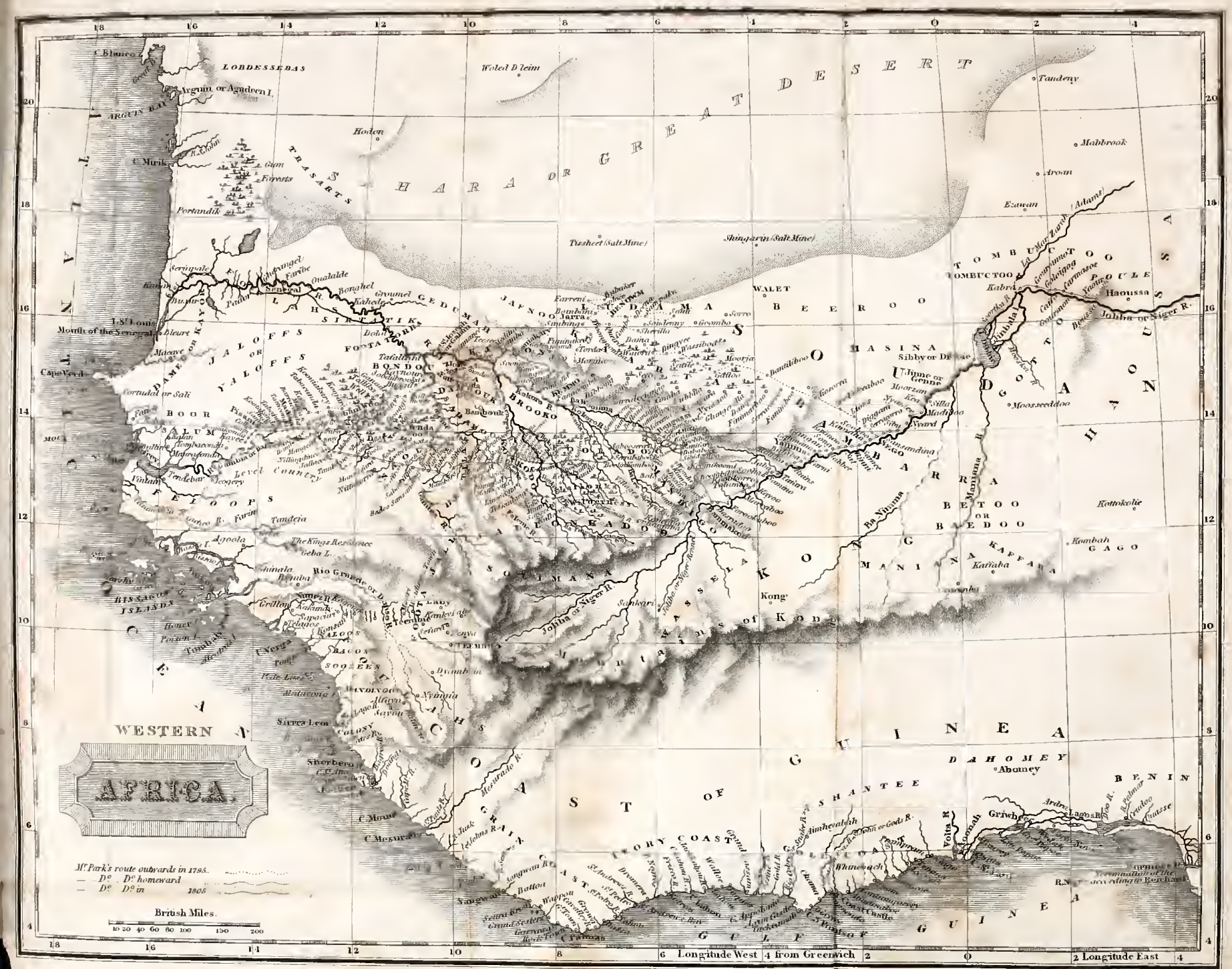

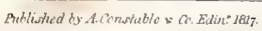



paralleled. It is remarkable also, that, among all the states of Europe, the lead should have been taken by Portugal, a power which did not seem destined to act any great part on the theatre of the world. Dr Robertson, in the introduction to his History of America, has well illustrated the causes which roused in that country the spirit of enterprise, and turned it into this sphere of exertion. The progress and successive discoveries of the Portuguese along the coast of Africa, are describ ed by that great historian with such animation and eloquence, as must have rendered them familiar to almost every reader. But few, perhaps, are aware of the vast exertions which they made to penetrate into the interior, and with such success, as to reach farther, in every direction, than has been attained by any of the moderns, with the sole exceptions of Park and of Browne. The details of these important transactions, have been hitherto locked up in the writings of the Portuguese authors, or have been reported elsewhere in a very mutilated and imperfect state. A pretty copious abstract of them, therefore, will probably not be unacceptable to those who feel any interest in the steps by which discovery proceeded through the interior regions of this continent.

The encouragement afforded by the royal family, and the general excitement throughout the nation, gave a sufficient impulse to the career inVOL. $I_{\text {. }}$ 
to which the Portuguese nation had entered. Yet, into the most splendid of human enterprises, there usually enters some odd and capricious mixture. The glory of the Portuguese name, the discovery of new worlds, even the opening of the sources of golden wealth, were all considered as subordinate to the higher aim of discovering the abode of a person, who was known in Europe under the uncouth appellation of Prester John. The origin of this mysterious name, which formed the guiding star to the Portuguese in their career of discovery, is somewhat difficult to trace. It attached itself originally to the centre of Asia, where it was reported by the early travellers, particularly by Rubruquis, that a Christian monarch of thiat name actually resided. 'The report probably arose from a confused rumour of the Grand Lama, or priest-sovereign of Thibet. The search accordingly, in that direction, proved altogether fruitless. At length it was rumoured very confidently, that, on the eastern coast of Africa, there did exist a Christian sovereign, whose dominions stretched far into the interior. Thenceforth it appeared no longer doubtful, that this was the real Prester John, and that the search had hitherto been made in a wrong direction. The maps of Ptolemy, then the sole guide of geographical inquirers, were spread out; and, on viewing in them the general aspect of the continent, it was 
inferred, incorrectly indeed, yet not unplausibly, that an empire, which stretched so far inward from the eastern coast, must approximate to the western; and that, by penetrating deep on that side, they could scarcely fail at length to reach its frontier. For this reason, whenever an expedition was sent out to any part of the coast, the first instruction given was, to inquire diligently if the inhabitants knew any thing of the monarch in question. Every opportunity was also to be embraced, of penetrating into the interior; and, on hearing the name of any sovereign, an embassy was to be sent to ascertain, if he either was Prester John, or could throw any light as to where that personage might be found.

So long as the naval career of the Portuguese extended along the shores of the Sahara, and they saw nothing before them but a "wild expanse of lifeless sand and sky;" no temptation was felt to form a permanent settlement. After passing Cape Blanco, however, the coast began to improve; and when they came to the fertile shores of the Senegal and Gambia, and saw ivory and gold brought down in considerable quantities from the interior, these regions began to excite the ambition of settlement and of conquest. The undertaking, however, was beyond the force of any expedition that had yet sailed from Portugal, Nunez Tristao, in attempting to ascend a small river near the Rio 
Grande, was attacked by the negroes, and killed, along with a number of his men. * An insular position appeared, therefore, the most eligible for a first establishment. 'With this view, Arguin was fixed upon. It was the largest upon this coast, and at such a distance from the shore as afforded protection against sudden attack. 'The neighbouring continent was altogether barren; but it maintained some profitable commercial intercourse with the nations in the interior. Soon after this establishment was formed, a very important event took place. Bemoy, one of the princes of the Jalofs, a people who inhabit the territory between the Senegal and Gambia, came thither to seek the aid of the Portuguese. He complained of having been unjustly expelled from the throne by one of his relations, and solicited a force to reinstate him in his dignity. $\dagger$ To princes, who have begun to cast a longing eye upon their neighbours' dominions, such an application is always an event of the most grateful occurrence. It secures to them a party in the kingdom towards which their views are directed ; and it gives an air of nobleness and generosity to what would be otherwise an odious and wanton aggression. Bemoy was received at Arguin with open arms, and the governor sent forward himself and all his train in a vessel to Portu.

* Di Barros, I. I4.

+ Ibid. III. 6 . 
gal. On his arrival at Lisbon, the King immediately ordered accommodations to be provided in the castle of Palmela, and all the honours shewn, to which European princes are entitled. Bemoy, in a few days, was brought to court, and was introduced to the King and Queen. They received him in presence of all their grandees, and with the utmost pomp which the court was capable of displaying. The Portuguese chronicles are lavish in describing the astonishment and admiration of Bemoy at this exhibition of European magnificence. When the public ceremony was over, he was introduced to a private audience of his Majesty, and had an opportunity of explaining, to a willing auditor, the grounds on which he sought his alliance and aid. He gave also a splendid descrip. tion of this part of Africa, mentioning, in particular, Tombuctoo, Jenné, and the extensive trade carried on by those cities. He added, that, beyond Tombuctoo, there extended, far to the east, the territory of a people, who were neither Moors nor Gentiles, but who, in many of their customs, strongly resembled the Christian nations whom he now saw around him. This circum. stance, above all others, animated the zeal of his Portuguese Majesty; since it appeared infallible, that this region must either be, or at least must very closely border upon, the actual dominion of Prester John. The prince was, however, warned, 
that, if he expected any aid from so pious a monarch, it was indispensable, that he should previously be washed in the water of baptism. It is not said that Bemoy manifested any reluctance to a conversion, by which he was to gain such impor: tant temporal advantages. Decorum, however, required, that a form of instruction should be administered; and while the expedition, which was to convey him back to Africa, was in preparation, he was placed under the tuition of some of the most learned doctors which the kingdom afforded. These venerable personages having made a favourable report of the fruit of their instructions, the Prince, on the 3d November 1489, was admitted to the honours of baptism. * On the same day, says the historian, that he received this eternal honour, he was admitted also to the temporal honour of arms of nobility, which consisted of a cross of gold in a vermillion field, with the quarters of Portugal on the border. He then did homage to the King as his liege-lord for all the lands which he should gain by his aid; and also to the Pope, in the person of his commissary, according to the form usually adopted by catholic princes. The king celebrated this event by all the exhibitions which were fashionable in that age-bull feasts, feats of dogs, and puppet-shews. Bemoy took this 
opportunity of displaying the prowess of some of his own followers. As the principal Portuguese cavaliers were making a display of their horsemanship, he called several negroes, who, on foot, followed and kept pace with the swiftest of these animals. The same negroes leapt off a horse, as it was riding at full gallop, and, following, again mounted, with the same promptitude as if he had been standing perfectly immoveable.

Meantime, * the Portuguese court were busily employed in equipping a fleet, which, under the shew of establishing Bemoy in his native dominions, might establish their own power on the fertile banks of the Senegal. The armament consisted of twenty caravels, well armed and equipped, and having on board a large proportion of land troops, with materials for building a fortress. The command was given to Pero Vaz d'Acunha, while Alvaro, a brother of the order of Dominicans, was sent with a body of monks for the purpose of converting the natives to the Christian faith. With this armament, Pero Vaz entered the Senegal, and began the erection of the intended fort. But it appears, that some misunderstanding arose between him and the African prince. The latter, probably, soon perceived, that the Portuguese were more intent upon laying the foundation of their

* Di Barros, III, 12, 
own power, than upon re-establishing himself on the throne of his ancestors. Whether he was thus drawn into a correspondence with the rest of his countrymen; whether he was merely suspected of such conduct; or whether, as there appears some room to imagine, the whole originated in a private quarrel, - it appears, that the Portuguese commander stabbed Bemoy to the heart with a dagger, on board of his own vessel. This event is said to have caused extraordinary chagrin to the King, and to have even induced him to give up all immediate design of constructing the fort; but a pestilential disorder, which made its appearance among the troops employed, might afford perhaps a more urgent reason.

The arrival, however, of so great an armament is said to have caused an extraordinary revolution in the minds of the African princes. Formerly they had seen only one or two small vessels, ill manned and equipped, and having on board a mere handful of mariners, who could not trade, nor even land, without their favour and permission. But the arrival of so large a force, both naval and military, and one so amply supplied with all the materials of war, impressed the most formidable idea of the power of this distant monarch. Not only the fear of his arms, but the hope of his support in those furious wars which they were waging with each other, induced them to send embassies, and 
to lavish presents and promises, in hopes of attaching him to their alliance. The king, therefore, although he had given up the design of building a fort, ordered his armament to remain in the river, and embassies to be sent to the most powerful of the neighbouring states. Those particularly mentioned are the king of Tongubutu (Tombuctoo), the king of Tucurol, and a king called Mandi Mansa, said to be one of the most powerful among those who occupied the territory of Manding; which name seems to have had then a very extensive application. With this prince, a very intimate alliance was formed. Several embassies were also sent to the king of Tombuctoo; but of those, unfortunately, no particulars are recorded. Another sovereign is also mentioned, Temala, king of the Foulhas, who, from the southern country of Foota, had invaded this territory with a force so immense, that, according to the poetical language of the Portuguese writers, the rivers were drunk up at which they stopped for refreshment. Although, however, Temala is said to have done much injury to the King's allies in this part of Africa, his officer does not seem to have ventured to embark in hostilities against him; but even carried on an amicable intercourse by message and embassy.

From causes already stated, the Portuguese maintained their importance in this quarter, were respected, and even courted by the neighbouring 
princes. But when, in their indefatigable search after Prester John, they ventured deeper into the interior, they did not always experience equal courtesy. From the fortress of Mina, on the Gold Coast, a message was sent to a very powerful Moorish prince called Mohammed, sovereign of a country which is not named, but which is said to lie in the parallel of Cape Palmas, about a hundred and forty leagues in the interior. This prince, in reply to the compliments of the Portuguese monarch, replied, that he had never heard of any powerful kings in the world except four; which were, the King of Cairo, the King of Alimaem, the King of Baldac, and the King of Tucurol. He added, that of the four thousand, four hundred, and four kings, of which he was the lineal descendant, not one had ever received or sent an embassy to any Christian prince; and that he had no intention to introduce an innovation in that respect. The am-. bassadors, upon this answer, lost no time in taking their departure.

Nothing, however, could damp the zeal of the Portuguese monarch, to discover the habitation of Prester John. He sent a body into the interior from Arguin to form a factory at Huadem (Hodem), distant about seventy leagues from the coast. They were directed to make diligent inquiry of the Brabariis (Bambarrans), and Ludaias (inhabitants of Ludamar), whether they could give any 
information that could lead to the much longedfor discovery. All declared, that they had never heard of such a personage, but agreed, at the earnest entreaty of the Portuguese, that they would make every possible inquiry in their native country.

It cannot be doubted, in the course of the indefatigable exertions thus made by the Portuguese, to penetrate into the interior of Western Africa, that they must have enjoyed opportunities of information superior to those which have fallen to the lot of any other European power. Some share of empty boasting may be suspected; but the great Portuguese population which the English and French found established along the banks of the Senegal and Gambia, clearly attests the substantial truth of their narration. The French, even in penetrating into Bamboak, found a mixture of Portuguese words in the language of that country, which confirmed the statement of the natives, that it had once been invaded and conquered by Portugal. It seems unquestionable, therefore, that the archives of the Portuguese monarchy must contain very important information respecting this part of the interior. It is probably owing to the reserved character of the Portuguese government, that the knowledge displayed by their writers does not altogether correspond to these opportunities. The fol- 
lowing, however, is a summary of the description of these countries, as given by Di Barros. *

The whole of this region is described as traversed by the rivers Gambia and Sanaga (Senegal), which receive various names, according to the countries through which they pass. Thus, the river which Europeans calls Sanaga, is by the Jalofs called Dengueh; by the Tucurols, Maio; by the Caragoles (Serawoollies), Colle; $\dagger$ when it flows through a territory called Bagano, which lies far. ther to the east, it is called Zimbala, $\ddagger$ which name is sometimes given to the district itself ; and, in the kingdom of Tombuctoo it is called Jça. Higher up, its name was unknown, although its previous course must have been very long, as being derived from sources far to the east, in the lakes called by Ptolemy, Chelonides, Nuba, and the river Gir. Thus it appears, that the Portuguese, notwithstanding their opportunities of knowing the fact, had no suspicion of the Senegal and Niger being separate rivers, and of one of them flowing eastward, Ancient report, joined to what they themselves most familiarly observed, prevented apparently such an idea from ever occurring to them. Di Barros

* III. 8.

+ This name seems readily convertible into Joli-Ba; the latter syllable being merely an adjunct, signifying river,

$\ddagger$ Jinbala of Park. 
only expresses his surprise, considering this immense length of course, that the Senegal should not pour a greater mass of waters into the ocean.

The banks of this great river are fertile, and covered with populous and commercial cities. The principal is Tombuctoo, situated three leagues to the north of the river, and which, on account of the gold brought thither from the great province of Mandingo, is resorted to by numerous merchants from Cairo, Tunis, Tremecen, Morocco, $\mathrm{Fez}$, and all the kingdoms of Northern Africa. These repair also to another city, situated on the course of the river itself, and which was formerly more celebrated than Tombuctoo. It is called variously by the Negroes Genná, Jannii, and Gennii (Jenné of Park). This city, as being situated further to the west than 'Tombuctoo, forms a species of rendezvous for all the nations which are nearest to the coast ; the Caragolees, Foulhas, Brabariis, Luddayes, and Jaloffs. Through the channel of these people, as well as of those situated near the head of the Gambia, and also of those bordering on the castle of Mina, gold came into the hands of the Portuguese. Yet Di Barros asserts, with, I suspect, very little reason, that the Gambia and the Senegal do not roll a greater quantity of golden sand than the Tagus and Mondego of his native country; and he conceives it to be the mere illu. sion of distance which led his countrymen to seek, 
through toils and perils, on the shores of these barbarous rivers, what a diligent search would easily have enabled them to discover at home in equal abundance.

The great desert is also described. It is represented as beginning at Cape Blanco, whence, spreading like a robe, with the river Senegal for its border, it wraps round the continent till it comes to drink the waters of the Nile, which communicate to it some portion of moisture. The territory, however, is not so wholly barren, but that it is peopled in spots called Abeses (oases). Of this territory, there are three kinds: That which is poorly covered with grass and shrubs, is called Azagar; that composed of fine sand without verdure, $S a$ hel; that formed of small stones in the form of gravel, Sahara.

Meanwhile, the progress of discovery was carried on rapidly in another direction. * The castle of Mina, upon the Gold coast, had been established as the centre of the Portuguese power, and as the point whence all further advances were to be made. It was now a long time since the sovereign pontiff had granted to the kings of Portugal the full dominion of all the lands which they should discover, from Cape Bojador to the Indies inclusive. This grant, made first to Henry, grandfather 
of the present monarch, had been confirmed to his father Alfonso. It was, indeed, observes the historian, less a donation, than the confirmation of a hereditary title, since the kings of Portugal had always considered as rightfully theirs, every territory which they were able to conquer from the infidels. After three years possession of the fort of Mina, the king no longer hesitated to add to his other titles that of " Lord of Guinea." From this time, he gave directions, that the naval commanders who discovered any new line of coast, should no longer content themselves, according to former custom, with planting merely a cross of wood upon the shore. They were to raise a pillar of stone, twice the height of the human body, and adorned with an escutcheon of the royal arms of Portugal. On this pillarwere to be placed two inscriptions, one in Latin, and the other in Portuguese, expressing the date of the discovery, the name of the king who had sent the expedition, and that of the captain by whom the pillar had been erected. On the top, a cross of stone, inlaid with lead, was to be erected. The first who set out to establish these ensigns of dominion, was Diego Cam, who took his departure from the castle of Mina. He touched first at Cape Lopez Gonsalvo, and then at Cape St Catherine, the farthest point yet discovered. He had not proceeded far when a very strong cur. rent set in from the land. The waters were dis. coloured, and, when tasted, were found to be fresh. 
This decidedly suggested the idea that they were near the mouth of some mighty river-; an opinion soon confirmed by a nearer approach. This river he called the Congo, from the kingdom through which it flowed; but it was afterwards found, that by the natives it was called the Zaire; and the two names have since, in Europe, been used promiscuously. The first step which our navigator took was to plant his pillar on the opposite side of the river; which has hence not unfrequently received the appellation of the Rio do Padrono, or River of the Pillar. Then, conceiving that the banks of so mighty a stream were likely to be fertile and well peopled, he determined to ascend it. The shores proved accordingly to be filled with people exceedingly black, and speaking a language which, though Diego knew those spoken on other parts of the coast, was wholly unintelligible to him. He had therefore recourse to signs, by the medium of which he was at length made to understand, that, at a certain number of days journey up the country, there resided a very powerful monarch, king of the whole region. Diego therefore determined to send a certain number of his men with presents for this prince; obliging, however, the guides to engage, that they would bring them back in safety within a certain number of days. The stipulated period elapsed, without any appearance of their return. But the natives being well received, and gratified with little presents, came- 
familiarly on board, as if they had been long intimate with the Portuguese. In this state of affairs, Diego formed his resolution. At a moment, when several of the principal natives were on board, he suddenly weighed anchor, and sailed for Portugal. He then intimated by signs to the people on shore, that he carried away their countrymen, merely to gratify his sovereign's desire of seeing and conversing with them; that he would return in the space of fifteen moons; and that, in the mean time, he left, as a security in their hands, those of his countrymen who had gone as ambassadors to the king. In fact, his grand object in this manœuvre appears to have been, to carry home these living trophies of his discovery; and he hoped, by teaching them the Portuguese language, while those left behind should acquire that of Congo, that a regular channel of communication might be opened. The king, on the arrival of this party, felt all the joy which his commander expected. In consequence of the instruction which the Africans had received on the passage, they were able to converse with some dégree of fluency, and gratified the king much by the intelligent answers which they returned to his inquiries. As the termination of the appointed period approached, Diego again set sail, in order to fulfil punctually his engagement. On arriving at the bar of the river of Congo, great was his joy to discover his countrymen whom he had left as Yor. I. 
hostages, and who had been treated in the very best manner during his absence. He now sailed forward two hundred leagues along the coast of Congo, and planted two pillars, one at Cape St Augustin, the other at a Cape, which, from this circumstance, was called Cabo do Padrao. On his return from this voyage, he visited the king, who was so much gratified by the treatment which his subjects had experienced, and by the whole conduct of the Portuguese, that he knew not how to load him with sufficient honours. In the course of the conversations which this commander held, the Holy Spirit is said to have begun to operate, so that the monarch not only became himself a convert to Christianity, but took measures for the general conversion of his subjects. He proposed, both that priests should be sent from Europe, and that several young men of rank in his country should go over to be baptized and instructed; who might thus form the most advantageous medium for diffusing religious knowledge among their countrymen. The king sent along with them a present of ivory, and of cloth made from the palm tree, being the most valuable articles which Congo afforded. These persons were received in Portugal with all the honours which the king uniformly bestowed on such of the African natives as came to visit him. They were speedily instructed and baptized, the king standing godfather to the principal envoy, and each of his lords to another, after 
which they all, in sign of satisfaction, took the names of those who had placed themselves in this relation to them.

After the chief of Congo had thus spent two years in Europe, the king, * in the year 1490, caused a new armament of three vessels to be fitted out for the purpose of conveying them back to their native country. Unfortunately, the plague happening to rage at Lisbon, found its way into the fleet, and a dreadful mortality ensued in their voyage to Congo. Gonzalo de Sousa, the commander, and Don John de Souza, ambassador and secretary, were among the victims. The expedition being thus left without a leader, was in danger of falling into complete disorganization. At length Ruy de Sousa, nephew to the deceased commander, though without any ostensible office, and going merely as a volunteer, was unanimously chosen to fill his uncle's place. Order being thus restored, the expedition arrived at Congo, and sailed up the river. The first place at which they landed was Sono, or Sogno; the governor of which was a nephew of the king, and called Mani Sono, which signifies "Lord of Sono." As soon as this prince learned the arrival of the Portuguese, he hastened to meet them, accompanied by a nume. rous train of his vassals, and by a prodigious sound of horns, kettle-drums, and all the instruments 
which the country afforded. He then stated that his instructions were to conduct them immediately to the king; but petitioned that he himself should be immediately baptized, as being at an age so advanced, that he might otherwise not survive to have the ceremony performed. A large houzse was therefore formed, and branches of trees cut by the prince's servants; and three altars with rich ornaments were erected. The sons of Mani Sono, and the whole train of attendants, expressed an earnest wish to have the same ceremony performed upon them; but he represented that this was a task which the king wished to reserve to him. self; and that, unless in his own particular instance, such a wish ought to be implicitly obeyed. After the ceremony, this monarch, says the historian, was so deeply impressed with the instructions of the Portuguese, and fired with so holy a zeal, that, hearing a noise made by some of his people at the door of the cliurch, he ordered them to be immediately put to death. The missionaries, however, very prudently interposed in their behalf, on account, as they state, of the scandal which might have arisen in consequence of so furious a zeal. Meantime, the mission which had been sent to the king to announce their arrival, returned with an invitation to repair to Ambassi, the city at which that monarch resided. The party set out, accompanied by upwards of two hundred ne- 
groes, carrying on their heads all the baggage, as well as whatever would be required for the service of the altar. They were met half way by a large deputation appointed to welcome them; but, at the distance of two leagues from the capital, a cavalcade appeared,on a much greater scale than any former one. They came in three lines, armed after the manner of the country, and with a prodigious noise of barbarous instruments, performing in such an order, as to remind the Portuguese of the processions for invocation and prayers for the saints. From time to time, the whole body raised a shout so tremendous, that it seemed to rend the skies. The burden of the song consisted always in praise of the king of Portugal, on account of what he was now sending to their sovereign. The troops of Congo then wheeled round, and the Portuguese being placed in the centre, marched to the spot where the king was preparing to give them an audience. It was in a large park, so covered with people, that they could with the utmost difficulty effect a passage. The king was stationed on a wooden scaffold of timber, so elevated, that he could be seen by the whole assembly. He sat in a chair of ivory, ornamented with some pieces of well carved wood. His dress consisted of skins of beasts, which are praised as glossy, and blacker than his own skin; the lower part of his body was covered with a damask robe, presented to him by 
Diego Cam; on his left arm he wore a bracelet of brass, and on his shoulder a horse's tail, accounted here a peculiar ensign of royalty. His head was covered with a bonnet of very fine cloth, made from the palm tree, with works in alto and basso relievo, resembling the texture of our velvet satin. Ruy de Sousa then did courtesy after the European manner, which the king returned in his own, by placing his hand on the ground, and making a semblance of taking up dust, then pressing it to the breast of the ambassador, and afterwards to his own. He then expressed a desire to see the holy things which they had brought along with them, which being taken out and exhibited one by one, were viewed with the utmost attention and reverence by the whole assembly. In this occupation they spent the day and part of the night, when the Europeans were shewn to the place appointed for their residence. Next day Ruy de Sousa requested that a church should be immediately erected; a task to which the king applied himself in the most zealous manner. There being no stone in the neighbourhood, it was sent for from a great distance; and every individual was obliged to labour, that the work might be finished with the greater expedition. Hence, though the Portuguese arrived only upon the 29th April, the first stone was laid on the $3 \mathrm{~d}$ of May, and the whole was completed on the 1st of June. The intended splen- 
dour of the ceremony of baptism was abridged, by the intelligence which arrived, that an insurrection. had broken out among a people inhabiting the islands of the Great Lake, from which the Zaire derives its source. For this reason, on the same day that the foundation of the church was laid, the king was baptized, with all his nobles, and a hundred thousand of his subjects. Ruy de Sousa then presented to him a standard with a cross, which would certainly secure victory, as being the same which Innocent VIII. had granted to the holy crusade, for the war against the infidels.

Nothing, it appears, could thus be more promising, than the original establishment of the Catholic faith in Congo. After the first ceremonies, however, had passed, the missionaries thought it incumbent on them to intimate to the king, as a part of his new profession, that he must dismiss the numerous wives whom he now maintained, and confine himself to one. This re. striction appeared so intolerable to the aged monarch, that, rather than submis to it, he renounced Christianity, and returned, with all his nobles, to the practice of Paganism. The ladies, in particular, are said to have taken a most active part in opposing such an innovation. Amidst this general defection, the only person who remained. steady. was the king's eldest son, called by the Portuguese Don Alfonso; and who; it appears, willingly submitted to the privation which his fa- 
ther judged so insupportable. A dissension thus arose between the father and son, which was fomented by Panso Aquitimo, another brother, who had, from the first, shewn himself an enemy to the new faith. He and his emissaries studiously collected every report which could embitter the mind of the king against his heir apparent. They assured him that, by the power of Fetiches, taught him by the Christians, Alfonso came every night from his residence at Cabo de Reyno, eighty leagues distant, carried thither one of the king's wives, and conveyed her back in the morning. They added, that, by the same power, he dried up the rivers, and injured the fruits of the earth, that the king's territories might not yield their usual revenue. These atrocities moved the monarch to such indignation, that he withdrew the revenue which had been allotted to the prince, and even took measures against his life. Some of Alfonso's friends, however, endeavoured to make him sensible of the injustice of these suspicions, and even proposed a plan for putting them to the test. A person was employed to wait secretly upon one of the principal wives, carrying a fetiche wrapt up in a cloth. This, he pretended, was sent by Don Alfonso, to protect her and her companions from the punishment of death, meditated by the king, on account of their nocturnal flighis to Cabo del Reyno. The princess indignantly rejected the 
present, declaring her total ignorance of the fact alluded to ; and having afterwards seen the king, she satisfied him that his information, as to these nightly excursions, was entirely unfounded. The violence of his resentment was thus appeased; but a coolness continued till his death, which happened soon after. Panso Aquitimo then took advantage of being on the spot, and of the favour of his heathen countrymen, to seize the vacant throne, without regard to the rights of his elder brother. Alfonso, on receiving the intelligence, repaired to a post near the capital, where he was only able to collect thirty-six Christians; while the cries of his brother's troops, heard from a prodigious distance, announced the numerous army by whom he was supported. Alfonso, however, we are assured, sent strict orders to his ad. herents by no means to come to his aid, as he placed his sole reliance on the aid of heaven, and wished nothing which could diminish the splendour of the miracle which was to be wrought in his favour. Accordingly, in a few days, he and his brother came to action; when Alfonso began by invoking the aid of the Apostle St James. St James appeared in the clouds, bearing the sign of the cross, and attended by " a numerous cavalry of angels ;" at sight of whom the unbelieving army fled with such precipitation, that their chiefs were left in the rear, and unable to save themselves. 
Panso Aquitimo, being entangled in the den of a wild beast, was taken, and died soon after. His principal commander was also taken; but, as he was leading to execution, professed himself now convinced of his error, and implored that, before death, he might receive the sacrament of baptism; that, whatever became of his body, his soul might be saved. This request appeared so edifying to Don Alfonso, that he granted him a full pardon, on the sole condition, that he and his posterity should sweep and wash the church, and should draw water for the baptism of the Tnfidels.

In regard to the battle in question, those who are not blessed with the measure of faith enjoyed by the Catholic historians, will, doubtless, suspect that it was mainly owing to the superior arms and discipline of the Portuguese. However, it is certain that the districts, situated to the south of the Congo, continued, during, more than two centuries, to profess a species of Christianity; and the Church of Rome, as we shall presently see, sent successive bodies of missionaries, who not only inculcated its doctrines, but sometimes exercised an authority almost paramount to that of the sovereigns.

Before following them, however, into the interior of Congo, it may be proper to notice some information which they collected on the coast of Benin. * 
The sovereign of that country, we are assured, on learning the first voyage of Diego Cam along his coast, was inflamed with such pious zeal, that he sent an embassy to Mina, requesting missionaries to instruct him and his court in the Christian religion. This request, if it really was made, did not appear one to be slighted. The king sent an expedition under Fernando del Po, who explored the coast of Benin, and gave his name to the large island at the mouth of the Rio Formosa. He was well received by the king, established a factory at Gatton, and built a church, which was attended by more than a thousand of the natives. Here the following intelligence was obtained: Twenty moons, which, according to their rate of travelling, might be two hundred and fifty leaguas to the east of the kingdom, there was a powerful king called Ogané, who was held, by the Pagan chiefs around Benin, in the same veneration that the sovereign pontiff was held in Europe. According to a long established custom, at the death of any king of Benin, the successor sent ambassadors to him with a large present, entreating to be confirmed in the territory of which he was now the rightful heir. The Prince Ogané then gave them a staff, and a covering for the head, similar to a Spanish helmet, all of glittering brass, to represent a sceptre and a crown. He sent also a cross of the same brass 
to be worn on the neck, similar to those used by the commanders of the order of St John. Without these ensigns, the people did not conceive they had a rightful king, or one that was properly a king at all. During the whole stay of the ambassador, the Ogané himself was kept up as a holy thing, and was never seen by any one, having constantly a silk curtain drawn before him; - - only, at the time the ambassador took leave, a foot appeared from behind the curtain," "to which foot they did homage as to a holy thing." The ambassador was then presented with a small cross, similar: to that which was sent for the use of the king. On receiving these details, the Portuguese monarch sent for all his cosmographers, who having spread out before them the map of Ptolemy, calculated that the reported distance ought to reach across the continent to the dominions of Prester John, and that this Ogané must consequently be Prester John. * This, however, did not lead to any new expedition of discovery into the interior, but only impelled the king to press the voyage by the Cape of Good Hope, which boundary of Africa had al-

* Major Rennell conceives the Ogané to be the sovereign of Gana, at one time the chief Mahometan state on the Niger. A late learned writer rather supposes him to be the Emperor of Abyssinia ; an opinion supported by pretty strong. probabilities; though the distance seems rather too great. 
ready been descried, and was soon after happily circumnavigated.

Having in the manner already noticed acquired a footing in Congo, the Portuguese formed a series of establishments along the coast, and even up some of the rivers. The opening thus afforded was employed by the court of Rome in sending out a succession of missionaries, with a view of converting the natives to the Catholic faith. These emissaries being monks of the strictest order, and deeply imbued with all its superstitions, did not communicate the best form of religion, nor in the most prudent and conciliatory manner. Neither, as travellers, are they very enlightened and judicious informants. They penetrated, however, deep into Congo, and even into the regions behind, explored by no other European. Their long residence, also, and the nature of thcir intercourse, gave them a more intimate view of the domestic and moral habitudes of the people, than can fall to the lot of an ordinary traveller. Our readers, therefore, may not find it uninteresting to follow them in their career through the remote and barbarous regions in the interior.

In 1640, * the Pope, at the request, it is said, of king Alvaro VI. determined to send a body of Capuchin missionaries into Congo. Some difficulty was experienced in obtaining permission from the

* Labat, Ethiopie Occidentale, III. ch. 1, \&c. 
court of Spain, which then reigned over Portugal, for the entrance of Italian missionaries into that region. At length, on the 20th January 1645, they set sail, nine in number, from the port of $\mathrm{St}$ Lucar ; and, after a tedious voyage, arrived at the mouth of the Congo. They were welcomed by the Count of Sogno, and, after a short stay, took their departure for San Salvador. The king received them in the most distinguished manner. A convent was built, every comfort provided, and the inhabitants came in crowds to be baptized. Almost every mission, at its first opening, went on in the most prosperous manner. So long as operations were confined to baptism, according to the Romish ritual,-to exhibiting images of the virgin and saints, - and to distributing beads, relics, and Agnus Dei's, the people were amused and delighted by becoming Christians. But they never suspected that this profession was to interfere with any of their ancient habits and superstitions. When these were attacked, and, above all, when the arrangements respecting their females came to be discussed, a violent struggle always arose. Here, as in the other negro states, every man maintained as many wives as his means or inclination allowed; and as each not only provided for her own subsistence, but contributed to that of her husband, they were in every way a desirable possession. When the missionaries, therefore, required the dismissal of 
all, except one, such a proposition staggered the faith even of the most zealous converts. They agreed, indeed, after some consideration, to invest one with the name of wife, while the rest received the humbler appellation of servants or concubines; but, as the change of name produced no change in the connection, and the children even were all treated in the very same manner, the missionaries could not listen to such a compromise. Indeed, though their conduct in this affair may not always have been perfectly temperate or judicious, they seem to have acted upon strictly conscientious motives; and the obstacle which they had to encounter was real and almost insurmountable. From this cause, a violent persecution arose against them in the states, both of the king and of the Count of Sogno. They succeeded, however, it does not exactly appear how, in appeasing it, and in re-establishing themselves on a friendly footing with these potentates. Being now reinforced by a new body of Capuchins, they determined to undertake missions into the interior, particularly to the countries extending upwards along the Congo.

The fathers Gabriel and Antony undertook the mission to Batta, the province nearest to the capital. It is situated, not immediately upon the Congo, but with its frontier extending parallel to that river, at the distance of twenty or thirty miles 
from the southern shore. This is one of the most fertile and populous districts of the kingdom; and the inhabitants, who are called Mosombos, are said to be the mildest and most humane of all its inhabitants. The duke, as he is termed, maintains a court, the splendour of which almost rivals that of the king. His army is estimated at seventy or eighty thousand men; and he is allowed, on account of the vicinity of barbarous nations to the east, to keep a company of musqueteers; a privilege not indulged to any of the other dependencies of the throne of Congo.

The missionaries, on their way, found the roads thronged with persons coming to be baptized. Whole villages flocked to them at once, so that they were often obliged to spend days on the road for the purpose of admitting these numerous converts within the pale of the church. At length they arrived at Congo-Batta, the largest town in the province, and the theatre of a considerable trade. Here, too, they found their ministration in such request, that they could scarcely find time for sleep or food. After nearly the whole city and neighbourhood had been baptized, they made a somewhat mortifying discovery. One part of the ceremony, according to the Romish ritual, consists in placing salt upon the mouth; which circumstauce, as salt is here scarce and an object of luxury, probably aided the alacrity with which the nation came to 
be baptized. As the fathers acquired a knowledge of the language, they discovered that the sole idea which the natives attached to the rite, was the eating of this small quantity of salt. Curia mungua, to eat salt, was, in their language, the term for being baptized; nor did the efforts to change either their language or their ideas upon this subject prove very successful.

From Congo-Batta the fathers went to a town called simply Batta, the residence of the duke, yet neither so large nor so wealthy as the one they had left. They were lodged without the city, in a cottage of shrubs and palm branches, which had been built expressly for their use. They had the satisfaction to find that it contained nothing which could wound the most rigid vow of poverty and austerity. Although, too, they were almost fainting with hunger, no provisions made their appearance. The duke's secretary, however, entcred and welcomed them with the most ceremonious politeness. As he departed, the fathers ventured an inquiry, when a small supply of food might be expected? The secretary assured them, that there was not the remotest intention of sending any thing of that description. In this country, it seems, it was considered an indispensable mark of respect, when a stranger arrived, to refrain, for a whole day, from offering him even a drop of water. The missionVOL. I. 
aries, seeing no remedy for this privation, were fain to acquiesce, and to receive it as a compliment.

Next day the duke waited on them, and received them with the same studied politeness as his secretary. On their expressing a wish for a church, he assured them that they should be immediately accommodated with one of his own planning. After his departure, some dishes made their appearance, which, though they in no degree endangered a breach of temperance, were sufficient to satisfy the cravings of hunger. The duke, however, forgot entirely his promise of building a church; so that, after spending some time in vain hope, they were obliged to hire negroes to construct, with branches of wood, a kind of large cottage, in which, with much indignation, they began to celebrate the mysteries of the Catholic faith. The people now began to resort thither; and even the duke attended, though somewhat irregularly. The fathers now conceived it necessary to touch upon the domestic state of the people; not one of whom, they observe, had a lavful wife, but all herds of concubines, the duke being more amply provided than any other. The first proposition made upon this subject was treated by that prince in the most indignant manner. It appeared to him an unheard of presumption in a handful of foreigners, newly arrived, and ignorant of the country, to attempt to subvert the 
longest established customs, and to abridge human life of its most indispensable rights and comforts. Yet, in a short time, without its being fully explained how, he changed his views,-dismissed all his seraglio,-and was married, according to the rules of the church, to a princess of Congo. Some symptoms of frailty soon made their appearance; but the missionaries succeeded, while they remained at Batta, in preserving him from any serious relapse. Finding every thing prosperous in the capital, they determined to make a tour through the country districts. They did not find much disposition to embrace their doctrine ; on the contrary, their preaching, their foreign aspect, and their ignorance of the country, afforded often subjects of merriment to the rustic inhabitants. A favourite entertainment seems to have been, to call to them that wild beasts were approaching, which could only be escaped by flying to the tops of trees, and to observe the vain attempts of the missionaries to perform that feat of agility. It was only by producing the orders of the duke that they were able to command a temporary submission. On their return to Batta they found a dismal change. The duke, taking advantage of their absence, had re-established his seraglio, on an augmented scale, and all the chiefs were hastening to follow his example. This relapse proved much more obstinate than the original malady. Before 
there could be time for effecting any reform, he was sent for to the court of Congo. All the men in a condition to travel followed him, and the women shut themselves up during the absence of their husbands. Batta became a desert; so that the missionaries had nothing left but to return to San Salvador, which terminated this mission.

Pango is a district, the situation of which has been very variously reported; but D'Anville, who proceeded usually upon sure information, extends it upwards, along the banks of the Congo, from the province in which the capital is situated, to within thirty miles of the cataracts, where it is bounded by the duchy of Sundi. No particulars have been preserved of the mission established in this marquisate, as it is called. Some account is given, however, of Father Antony's passage through it, on his way to Sundi. At setting out he hired four very stout negroes to carry his baggage. As soon, however, as the journey commenced, these persons began to run with a swiftness which the worthy father in vain attempted to rival. He was soon left behind; but luckily found, at some distance on the road, his baggage, which the porters, on looking round, and missing him, had probably thrown down. In this embarrassing situation, he met a messenger from the marquis of Pango, who procured every thing that was necessary, and conducted him to Pango, where he was received in the very best 
manner. On his return, he stood in still greater need of this hospitality. The duke of Sundi was on his way to court; and, as it is the system of the princes in this country to seize whatever they find on their route, all the inhabitants had fled to the tops of the highest mountains, and left the country entirely a desert. 'The father arrived, therefore, in a very exhausted condition at Pango, where he was again most hospitably received, and every comfort and refreshment liberally afforded.

Sundi is a large province, extending along both banks of the Congo, from the frontiers of Pango to considerably beyond the cataracts. It is commonly held by the eldest son of the king of Congo. The plains, being watered by numerous rivers, are exceedingly fertile; but the combtry to the east and north is very mountainous, and inhabited by barbarous tribes, who owe little more than a nominal subjection to the duke of Sundi. They agree, indeed, to pay a tribute; but this tribute is scarcely ever levied, unless by force of arms. An extensive trade passes through the country, consisting in the exchange of salt, cotton goods, and dyestuffs, which come up the river, for cloths made of the palm tree, ivory, and furs, brought down from the interior. The mountains abound in mines, particularly of copper of a very brilliant yellow; but iron, as the substance from which arms are 
manufactured, is the metal chiefly valued. Crystal is also abundant. Sundi, the capital, is situated about six leagues below the cataracts.

The mission to Sundi was undertaken by Fathers Jerome and Bonaventure. They experienced at first the utmost coldness and indifference ; nor could they, without the utmost difficulty, construct a wretched cabin of wood and straw, which might perform the functions of a church; and when this church was completed, no one seemed inclined to enter it. It so happened, however, that an immense cloud of locusts passed over the city, and committed dreadful ravages in the surrounding country. In this calamity, the people had recourse to the missionaries, who, reminding them of their sins, immediately ordered a solemn procession. This did not produce any effect; but they continued their operations, till at length, after one of their solemn exorcisms, a high wind arose, and swept away those destructive intruders. The glory of this deliverance, in the eyes of a superstitious people, was readily ascribed to the missionaries. The fame of this event reached the ears of the duke, who was then on the opposite side of the Congo, and excited in him a curiosity to see those by whom so signal a miracle had been wrought. Father Jerome therefore crossed the river, and repaired to the prince's residence. Arriving late at night, he was lodged, from re. 
spect, in the largest house; but, when day-light appeared, was petrified to discover that he had been sleeping in an idol's temple. However, in the morning, he was introduced to the prince, who received him very cordially, lent a ready ear to his instructions, and soon became a complete convert. He always delayed, however, on very insufficient grounds, the entering into that full confession, which was required by the missionary. This inducing a strict inquiry into his life and conversation, it soon proved, that nine concubines, to whom he was passionately attached, formed the secret cause of this obstinate silence. The number, for an African prince, appeared by no means extravagant; but the missionary did not the less insist upon a strict conformity to the Christian rule. The prince, seeing no remedy, at length consented to dismiss eight, and retain only one; but he shewed the most extreme reluctance against being united to that one, according to the rites of the church. The father, however, would listen to no compromise, and at length carried his point.

Every thing being thus satisfactorily arranged at court, the father made an excursion into the country. He came first to Boenza, a large town, which he found swarming with idols. $\mathrm{He}$ announced to the chief the orders of his sovereign, that all these should be overthrown, and Christian. 
ity established. The chief declared his own perfect readiness to accede to this innovation; but observed, that the mere report of such a step had very nearly caused a revolt, and he was convinced, that its precipitate execution would be attended with the most alarming effects. The father having used in vain every argument which could dispel this panic, had recourse to more vigorous measures. He seized a large staff, and running through the town, beat down all the idols stationed in the streets; then collecting the fragments, formed them into a lofty pyramid, to which he set fire. The whole air was soon in a blaze. The people, alarmed, ran from their houses, and having seized the missionary, immediately prepared to put him to death. He had fallen on his knees, to await the last blow, when the prince, having heard of his danger, ran and rescued him.

At Esseno, matters came to a still greater extremity. There was in this place a personage who called himself Chitorné Scingilla, or God of the Earth. Two stones, with a rivulet flowing before them in the middle of the principal square, were reserved for his use. On one of them sat himself, and on the other his principal concubine; and here the prince, with all the people, came to prostrate themselves before him, and to offer him magnificent presents. It was believed, that if these stones were moved, or even touched by any profane hand, the 
brook would immediately cease to flow. The missionary having gained the concurrence of the prince, went to the stones, pushed them from their places, and exhibited to the people the stream pouring on as copiously as ever. The prince was so delighted with this incident, and seized with so ardent a zeal, that he assisted the father in overthrowing no less than six thousand idols which had been erected within his dominions. The people were far from viewing with pleasure this demolition; on the contrary, they unanimously rose in arms; and the prince learned that twenty thousand were approaching to attack his capital. He himself had only four hundred; but being fortified by Jerome with a rosary, and advised to place his sole confidence in the Virgin, he marched out, gave battle to this immense multitude, and totally defeated them.

Affairs being thus tranquillized, the missionary ascended the river to Concobella, a barbarous region, which lay entirely beyond the jurisdiction of Congo. It was dependant upon Micocco, or Anziko, an extensive kingdom to the north-east, and shared all the ferocious and savage habits which rendered the inhabitants of that region the terror of Africa. The sovereign, though acknowledging some homage as due to another, was himself very powerful ; and assumed not only the title of King of Concobella, but those of Lord of the Waters, and Superintendent of the Elements. So mighty 
a monarch was not to be approached without proper ceremony ; the missionary, therefore, thought it expedient that his arrival should be preceded by. a few presents, which, though of little value in $\mathrm{Eu}$ rope, were well calculated to dazzle the eye of a monarch in the heart of Africa. They secured to him a most gracious reception, of which he soon received a proof, entirely characteristic of those by whom it was bestowed. The king had been sitting in judgment upon some of his subjects, who, at the instigation of a Singhilli, had been excited to revolt. According to the established practice of the country, the bodies of persons thus con. demned were sent to the king's favourites to be used as food; in which capacity, they were considered as the most delicate of any that could be procured. The king, willing to pay a compliment to his new visitor, selected the best conditioned of these subjects, and sent him to the father, hoping that he would find him afford some excellent meals. Jerome, though he had no relish for this diet, deemed it prudent to take the compliment in good part, and sent back polite thanks for so handsome a present. He soon found himself in high favour at the court of Concobella. The king, to testify his regard, proposed, and even urged, that he should accept his daughter in marriage; and this example was followed by all the chiefs, who were eager to illustrate themselves by an alliance with 
one whom they considered as holding a high rank in his native country. The father assures us, that, notwithstanding the force of the climate, it cost him nothing to reject positively all these proffers. $\mathrm{He}$ even succeeded in converting the king, and in prevailing upon him, out of five wives and innumerable concubines, to retain only one. The nobles, however, and the rest of the people, declared, in the most decided manner, that the immemorial practice of the country being to keep concubines, and eat human flesh, they would on no account renounce such valuable institutions at the mere command of a stranger. This caused them to lend a ready ear to a certain evil disposed person, who assured them, that the father was a mere bankrupt merchant, and one, who having, by magical arts, caused the death of two sons of the king of Congo, had thus been obliged to fly in disguise, in hopes to escape the punishment of his crimes. Although this calumny was repelled by the king, it made a considerable impression upon the nation. When the missionary, therefore, proposed to undertake a journey into the kingdom of Anziko, he was advised, under present circumstances, to proceed no farther; an exhortation which he deemed it prudent not to reject. His sole converts in Concobella, therefore, being the king, queen, and the young prince, there appeared no sufficient motive for prolonging his stay, and he returned to Sundi. 
Concobella is a large city, about three miles in circumference, situated on the northern bank of the Congo. According to the map of D'Anville, it is about seventy miles above the cataracts, in a north-east direction ; and upwards of four hundred from the mouth of the Congo. As the mission to Micocco or Anziko, though often projected, was never carried into effect, this city remained the utmost limit of European discovery, till the farther progress made by the recent expedition.

The missions which we have now noticed, were sent to the northern part of Congo, and to the countries situated along the great river, by which that country is watered. But some others, which were sent into the southern part of the interior, may also deserve notice. The most remarkable was that dispatched in 1653, at her own request, to Zingha, queen of Matamba. * Some account may here be necessary of that remarkable personage, and of the people over whom she reigned. The Giagas are a race painted by travellers in such frightful colours, that it is difficult to avoid some suspicion of exaggeration, and even of fable. Yet the eyewitnesses, who are numerous, agree, without a single exception, in the most revolting features of the picture. This people seem to have organized into a species of religious system, every atrocity of which human nature can be conceived capable. As they 
are continually employed in war and plunder, children would be a burdensome encumbrance; they are therefore regulariy murdered, or exposed after birth : the glory of the parents consists in perpetrating this savage deed with the most frigid indifference. Their slaughtered enemies, and the captives taken in war, are eagerly devoured; human flesh is considered as the most delicious food, and goblets of warm blood the most exquisite beverage. The death of their kings, or other great men, is signalized by a host of human sacrifices. All the details correspond with these general features, and compose a character far surpassing in atrocity that exhibited by the wildest savages of the new world.

Zingha was sister to the king of Matamba, a kingdom which partially shared the atrocities of the Giagas. In 1622, she came to Angola to negociate a treaty between her brother and the Portuguese government. The council were struck with admiration and even astonishment at the acuteness of her understanding, the vivacity of her wit, and the dignity of her deportment. As she made some stay at Angola, the viceroy proposed to her to be instructed in the mysteries of the Catholic religion. She readily agreed; either was, or pretended to become, a convert, and was baptized before her departure. Soon after her return to Matamba, dissensions which had arisen in her family, afforded her an opportunity of mounting the throne of Ma. 
tamba. Finding then that the habits of her new profession were ill calculated to maintain her influence with her subjects, she renounced Christianity, and strove to surpass them in every species of savage enormity. The Giagas were her immediate neighbours; every thing was to be dreaded from them as enemies; every thing to be hoped as friends. She embraced their diabolical system; she imposed upon them by a pretence of supernatural power; and finally succeeded in being chosen as their queen. At the head of such formidable allies, she soon became the most powerful sovereign in this part of Africa, and the terror of all the neighbouring regions. In this career of conquest, crime, and butchery, combined with brutal voluptuousness, she spent twenty-eight years: Yet she is said to have afterwards assured the missionaries that she plunged into these excesses with loathing and disgust; and from no motive but the dread of losing her influence over her subjects, and even of driving them into open revolt. The assertion seems confirmed by the narrative of some fathers who were in mission at Ovando, when that territory was conquered by Zingha. As all the people of the town were precipitately flying, the fathers, who could hope for no safety in speed, retired to the church to await the stroke of death. The soldiers, however, entering, merely put fetters on their hands, and carried them before the queen. That 
princess received them in the most gracious manner, and having dismissed her attendants, pris vately assured them, that it was with extreme reluctance, and only from necessity, that she followed the barbarous customs of the Giagas; that she was still a Christian at heart, and would prove herself to be so whenever circumstances permitted. She shewed extreme pleasure in hearing them speak Portuguese, of which language she was perfectly mistress. These impressions, however, did not produce any fruit in the mind of the queen, till she had arrived at the mature age of sixtyeight. At that time, the accidental sight of a cross is said to have rekindled, in all their energy, the sentiments by which she was formerly attached to the Catholic faith. She therefore transmitted an application to the church of Rome, for missionaries to instruct herself and her subjects in its doctrines. Such was the zeal, or such the obedience of the fathers, that no dread of this demon in female form produced any difficulty in finding men who were willing to undertake so formidable a mission. Fourteen were accordingly selected, who set sail from Cadiz on the 18th July 1654, and arrived at Angola on the 18th November. They immediately began to ascend the Coanza, a deep and rapid river, nearly of the magnitude of the Po. With difficulty they reached the town of Massignano, about a hundred miles from its mouth. 
Here the natives shewed the usual readiness, and even zeal, to be baptized, and to adopt the outward forms of Christianity. To meet these good dispositions, such toil was required, that the missionaries were all seized with the inflammatory fever peculiar to the country. The danger of the disease, though great, was much less than that which arose from the mode of curing it. The principle upon which the faculty in Congo proceeded was, that, before the constitution could be fitted to endure the change of climate, every drop of European blood must be drained, and its place supplied by African blood. They conceived it impossible, therefore, to go too far, so long as the patient did not actually die under the operation. This treatment was accompanied with purgatives similar to those which in Europe are administered to horses. Such, however, was the strength of their constitution, that, after four months illness, they all recovered. They proceeded then to the court of Zingha, having been previously assured of a cordial welcome. At the distance of two miles, the principal officers met, and conducted them to the spot, where the queen, surrounded by her guards and all her attendants, was stationed on the top of a little eminence. On seeing them, she instantly fell prostrate on the ground, and, bathed in tears, bade them welcome. She then rose, took the father by the hand, and overwhelmed him with thanks. They soon reached the throne, 
which had been erected before the gate of the palace. This throne consisted merely of Indian mats spread on the ground, and covered with a velvet carpet and cushions. The queen made the father sit down by her, and received a message with which he was charged from the viceroy, to which she returned a satisfactory answer. After so promising a commencement, it may easily be supposed, that the full conversion of her majesty was no difincult task. She applied herself with alacrity to gratify the first demand of the missionaries, which related to the building of a church. If the splendour of this edifice did not equal the expectation rationally formed from so powerful a monarch, the blame could be imputed only to the imperfect skill of her architects. The whole of their art amounted to fastening stakes in the earth, plastering them with mud, raising branches in the form of a roof, and covering these with straw or palm leaves. Such being the best edifice which the country could afford, there was no room for complaint. The first steps were always easy; and the new faith being favoured by the queen and all her grandees, a large proportion of the people were quickly converted, or at least baptized. Due preparation being thus made, the queen issued the following instructions to her principal officers and to the governors of pro. vinces: "That no person should invoke or offer "sacrifices to the devil, or idols of any description; VOL. I. 
" that infants should no longer be exposed in the " woods to be devoured by wild beasts; and that " no one, under pain of death, should eat human "flesh." The missionaries then informed her, that, to complete these good works, one thing alone was wanting, which was to marry. Zingha did not tamely acquiesce in this demand. She urged, that, after leading a long life of celibacy, it would be indecent and ridiculous, at the advanced age of seventy-five, to engage, for the first time, in the bonds of matrimony. The missionaries, however, insisted, that it was altogether necessary to set this example to her subjects; and she was probably aware, that there might be other motives, rather understood than expressed, derived from the course of life which she had been pursuing. She at last, therefore, chose a young courtier of humble birth, but who, being a good Catholic, gave entire satisfaction to the missionaries.

The most alarming symptom of relapse which the queen ever presented, occurred at the death of an old officer, whom she highly esteemed, on account of his military scrvices. She sent to the missionaries, requesting that he might be buried in holy ground. This person had been outwardly a Christian; but as his life had not been an ornament to the profession, the father would by no means hearken to this proposition. The queen, having exhausted in vain every form of entreaty, at length 
indignantly declared, that, since his funeral was not to be Christian, it should be according to his native rites. These consisted, besides a number of superstitious ceremonies, in the selection of a number, suited to his rank, of human beings to be interred along with him. The victims being chosen, were led, in barbarous procession, into the depth of a neighbouring forest, where the tombo, or vast pit, had been prepared. On learning this disastrous news, the missionary formed at once a bold and generous resolution. He hastened to the spot, and at the moment when the fatal ceremony was about to begin, suddenly appeared, raising the sign of the cross. The multitude gave way, and allowed him to approach the queen, who was standing under a portico. On discovering him, she instantly prostrated herself on the ground, and burst into tears. She allowed the missionary to remonstrate on the crime she was about to commit, set the victims at liberty, and solemnly promised never more to permit the celebration of so inhuman a ceremony.

The court of the queen is described to be as numerous as that of any of the sovereigns of Europe. Rank was conferred solely by office, birth being regarded as nothing; the only distinction was that of sovereign and slave. The moment any man lost her favour, he fell at once into the mass of the people. Merit, of that barbarous kind, 
which is valued in such a society, is said to have been the sole ground of promotion. The queen had three hundred women, ten of whom, by turns, attended constantly upon her person. Unless when indisposed, she ate constantly in public. Before the door of the palace was spread a large table, covered with numerous dishes, placed on vessels of earthen ware. At this table, there was neither plate, knife, fork, nor spoon. The royal fingers were the sole instruments employed in taking up the food and conveying it to the mouth. In the utmost height of her religious zeal, and notwithstanding her advanced age, she took always peculiar delight in adorning her person. Besides the finest cloths which her own country produced, she constantly wore the richest stuffs and brocades of Europe. In the days of her idolatry, she was accounted not only the greatest queen, but the most eminent magician and conjuror in this part of Africa. This character was maintained by the most extensive system of espionage, and by then making a display of the secret information thereby acquired. So strongly rooted in the minds of her subjects was this belief of her supernatural knowledge, that persons often came to throw themselves at her feet, to implore the forgiveness of crimes, of the existence of which she had not entertained the slightest suspicion.

Zingha continued to profess the Christian reli- 
yion till her death, which happened on the 17th December 1663, at the age of eighty-one.

To the south of Matamba is situated an extraordinary natural phenomenon, called Maopongó, or the Castle of Rocks. At a distance, it appears to compose only one immense mass, but proves, on a nearer approach, to be separated by ravines into a great number of distinct portions. Nature seems here to have amused herself in mimicking the most varied productions of art; towers, steeples, porticos, arches, obelisks, mausolea, appear as if intermingled; and the whole presents, at a little distance, the appearance of an immense and magnificent city. The entire mass is about 27 miles in circumference. Down the sides of the rocks descend numerous streams, some fresh, others salt; the latter of which are supposed, probably by the mere power of imagination, to ebb and flow along with the sea. No description is given of the nature of the rock; but the structure seems clearly to indicate that peculiar species of sandstone, which produces similar appearances in different quarters of southern Africa, as well as in some parts of Europe. *

On the top of these rocks, and along their base,

* Dritter Sandstein of Werner. See Jameson's Geognosy, ch. viii. 
are situated thirty-two villages, the inhabitants of which subsist entirely on the spontaneous produce of the earth. The trees grow to an extraordinary height; all the fruits of Africa are reared in perfection; the oranges, in particular, are equal to any in the world. Their religion was derived from the impious sect of the Giagas. In 1655, two missionaries were sent from Massangano to convert the inhabitants of this rock-district. On coming to the foot of it, they were first admitted by what was called the gate, consisting of a long and narrow pass, through which they, with difficulty, made their way, by creeping on all-fours. They then came into one of the ravines, a complete labyrinth of rocks and bushes, through which, without a guide, it would have been altogether impossible to penetrate. The guides led them to the foot of a lofty rock, which, to their eyes, appeared altogether inaccessible. Their negroes, however, sprung up like goats ; but the fathers, in attempting to imitate this agility, were soon compelled to call aloud for help. The negroes returned, took them on their shoulders, and leapt with them from rock to rock, till they arrived at the palace of the king, Angola Aarij. That monarch took them in his arms, embraced them, and assured them of every aid which he could afford to their efforts to diffuse the Christian faith. They were then shewn to an interim habitation, which 
had been assigned till a better could be erected. Unfortunately, a herd of goats had been dislodged in order to fit it for their reception; and the scent of these redolent predecessors was still very prevalent. The negroes, however, assisted in cleaning the abode, and they were soon provided with an abundant supply of provisions. The people, as usual, came in crowds to be baptized, and a great part of the nation was soon outwardly Christian. The missionaries, however, when they came to touch on their private life, and to insist on the reduction of their domestic establishments, encountered the usual obstacles. They found, in particular, that the favour of the monarch was thus entirely forfeited. That prince reproached them with disturbing the peace of the state, by introducing innovations, of which no one had ever before had the remotest idea. He added, that the harshness of their deportment was such, as rather tended to frighten the people from the profession of Christianity, than to allure them to embrace it. The fathers treat this last charge as the clearest proof of inveterate malignity; yet some circumstances, of which they themselves boast, may excite doubts in the mind of the reader, whether the strictures of the monarch were so wholly unfounded. Meeting with one of the queens, who, with a numerous train, was giving the air to an idol, and singing its praise, the missionary stopped her, and 
began a long discourse, to shew the vanity of this worship. Seeing, however, that his arguments were of no avail, he determined to employ a sharper instrument--the whip. Such was the awe of the missionaries, that not one of the attendants attempted to defend their mistress in this extremity. The father, therefore, immediately directed his two attendants to begin the work of flagellation. In proportion as the blows descended on the sacred person of her majesty, her understanding, he says, was gradually opened; so that, when a due number had been applied, she declared herself wholly unable to withstand such sensible proofs of the excellence of their doctrine. The fair convert, however, is not said to have expressed gratitude for this mode of delivering her from the errors of paganism; nor would it appear, as if she reported the occurrence very favourably to the king. That monarch shewed, ever after, the most marked coldness to the missionaries, and was evidently deterred, only by the dread of the Portuguese power, from banishing them instantly out of his dominions. The only thing which they could now do, was to steal secretly into the idols' temples, and set them on fire. By this proceeding, they exposed themselves to imminent hazard of their lives, and incurred the furious displeasure of the king. The ladies of the court, too, who did not approve the mode of conversion which had been 
adopted in their case, resolved to avenge the cause of their sex. For this purpose, they chose the opposite bank of a rivulet which flowed before the garden of the missionaries as their place of bathing, where they exhibited themselves during the whole day, often in very indecent attitudes. The afflicted fathers laid their distress before the king, but soon found the evil doubled by this proof of the effect which it had produced. They had, at last, no remedy but to build a high wall in front of their garden.

The next affair had a more satisfactory termination. One of the fathers happening to go into a smith's shop, entered into religious conversation, and endeavoured to inculcate the truth, that there was only one God. The smith, smiling, observed that he was mistaken,-there was another; and in reply to the eager inquiry which this statement excited, added, that this other was himself. On investigation, it accordingly proved, that he had a numerous train of adorers, who maintained, that the admirable works which came from his hand, could be produced only by supernatural power. The fathers instantly dragged this new divinity before the tribunal of the king. That prince, who had himself some pretensions to deity, did not choose to have a rival among his own subjects. He delivered, therefore, the smith-god into the hands of the missionaries, to be reduced to a mortal, in any manner which they might deem expedient. 
Finding argument vain, they had speedy recourse to their ultima ratio - the whip. All the votaries of Vulcan fled, when they saw their master reduced to such an extremity. He himself, however, continued to assert his dignity, till the blood began to stream from his back and shoulders, when he feelingly admitted that there was one God only, and that one not himself. In order to impress this important truth more deeply on his mind, the missionaries continued the "salutary flagellation" for some time longer, when they at length dis: missed him.

The missionaries finding now, that they had lost all credit and favour, both with court and people, judged it advisable to return to Massignano.

The two following Narratives by the Italian Missionaries, Carli and Merolla, are given in much greater detail than those of their predecessors; and though tinged with equal credulity and superstition, appear to present a considerable portion both of curious information and amusing in: cident.

In 1666, Pope Alexander VII. sent out two Capuchin friars, Michael Angero of Rheggio, and Denis CarlI * of Piacenza, upon a mission to Con-

* The narrative was published by Carli in Italian. Iq was translated and published in Churchill's Collection, 
go. To qualify them for so arduous a situation, they were invested with some extraordinary privileges, such as giving plenary indulgences, delivering a soul out of purgatory, wearing secular clothes in case of necessity, and, we know not why, of reading prohibited books, except Machiavel. Thus furnished, they set sail, and after touching at Brasil and the Cape, proceeded to Congo. The first port at which Carli, the narrator, landed was Benguela, which he found inhabited by 300 Portu. guese, and a great number of negroes. He describes it as the most unhealthy place he ever knew; he was even assured, and fully believed, that an European who, without being seasoned, eat any of the native productions, died instantly. He peremptorily refused to dine with the governor, till he had received solemn assurances, that every thing at table should be European. The people, he says, look as if dug out of the grave; they are also the wickedest and most deceitful of men; which he accounts for, by their being chiefly convicts sent thither, as to a place of punishment.

From Benguela our traveller sailed to Loanda. The port there appeared to him the finest and most beautiful he had ever seen. The town is situated on an island of the same name, and is the capital

Vol. I. (London, 1704,) and has since been reprinted in the 16th volume of Pinkerton's Collection. 
of all the Portuguese settlements on this coast. It is tolerably large and handsome, contains 3000 whites, and an infinite number of negroes. The last were chiefly slaves to the whites, some of whom, being very rich, have hundreds, and even thousands of slaves.

At Loanda, the missionaries procured guides to conduct them into the provinces of Sogno and Bamba. They at first proposed to walk; but were assured, that this was a mode of travelling not at all suited to the country. Thirty negroes were therefore appointed, to convey themselves and their baggage; two of whom carried each missionary, swung in a species of hammock. They stopped for the night in the first libatte, or village, at which they arrived. This libatte consisted of about a hundred cottages, scattered over a wide space of ground in the most irregular manner. They were all of one construction; "for throughout all the kingdom, there is never a stone house, but only of straw or stubble." These habitations, indeed, are used rather to sleep than to live in. The men spend the whole day in the open air, walking, conversing, amusing themselves, and playing on musical instruments. The women depart at day-break to till the ground, carrying or leading all their children along with them, and do not return till the evening. The village is surrounded with a strong hedge of thorns, for the purpose of excluding wild animals. 
At this place the missionary began the work of conversion, which seems to have consisted in the mere manual operation of baptism. As soon as he arrived, the makolonte, or chief, sent round the libatte, ordering all the inhabitaits to bring their children, that they might undergo that operation. They came in considerable numbers; and it was expected, it seems, that each should bring some present " by way of alms," in return for so great a spiritual benefit. Two handkerchiefs, 3500 cowzies, or a fat pullet, formed the usual gifts. Those, however, who had nothing to give, "were christened for God's sake." Two masses were then said, and catechetical instructions given, after which the people began to celebrate the occasion, "by playing on various instruments, that they might be heard half a league off."

The chief circumstance by which the journey is diversified, appears to be the peril and alarm from the approach of wild beasts. Our auther felt no small trepidation, when, lying asleep in his hammock, in one of the libattes, he heard, on the other side of the hedge, three great lions, " roaring that they made the earth shake." Happily the hedge proved too high for them ; and Carli, in the morning, finding that his companion's rest had been undisturbed, warmly congratulated him on his escape, since otherwise, " he might have gone to heaven, without knowing which way." Soon after, as 
they were travelling, a still more serious alarm arose. A conflagration, kindled at some distance, drove towards them all the wild beasts of the district. The negroes immediately sprung to the tops of trees; and the worthy fathers, little accustomed to such feats of agility, were with difficulty dragged up by ropes. There was no time to be lost; for such a host immediately arrived, that the whole party " would scarcely have made one good meal " for them." He enumerates tigers, lions, wolves, pocasses, and rhinoceroses. These all looked up, and eyed them very earnestly; but the fire behind, and the arrows which the negroes shot down upon them, speedily induced them to forbear any further pause.

Besides the inhabitants of the libattes, or villages, there is another class who wander in the fields, sleep under trees, and live almost in a state of nature. From among these, there was brought one day "a handsome young woman, stark naked," for the purpose of baptism. The missionary, having very prudently caused her to be covered with a few leaves, gave her some instructions, and performed the ceremony. This event, from some unknown cause, excited the most extraordinary exultation throughout the village. All the musical instruments were set in motion; and the people, making a circuit round the fair convert, cried with their whole might, " Long live Anne, long live 
Anne!" in a manner so tumultuous, as to put the missionary almost out of his senses. As soon as possible, therefore, he proceeded on his journey, and in a few days arrived at Bamba. This he describes as a large and populous town, though without giving any idea of its precise dimensions. The country round is very fertile; and he saw, with admiration, all the fruits both of Africa and America, with the exception of pears, apples, nuts, and a few others, which flourish only in a cold climate. There are two harvests. The one is sown in January, and reaped in April ; the other is sown in September, and reaped in December. The duchess of Bamba immediately sent to bid him welcome, and to express her wish to see him; but he requested some time to refresh himself, after the fatigues of his journey. Having heard, however, that the king of Congo was arrived at Pemba, ten days journey distant, he determined to go thither and visit his majesty. This journey he accomplished, baptizing by the way, and was speedily introduced to the king, Don Alvaro, a young negro about twenty. He was dressed in a scarlet coat with gold buttons, and wore commonly white buskins above silk stockings. One of the attendants bore his umbrella, of flame colour, and laced with gold; another a chain of carnation velvet, with gold nails. He received Carli graciously, and invited him to go on to San Salvador; but the missionary 
stating that he found his services more needed at Bamba, the king gave him a letter to the grand duke; after which, Carli returned to Bamba.

Soon after his return, an incident occurred, which gave him a high idea of the Congo Christians. One evening after sunset, he heard a very loud concert, of the most doleful sounds that had ever met his ear. This was found to proceed from the inhabitants of a neighbouring libatte, who had come to submit themselves to the discipline of the church. On repairing to the place of worship, he accordingly found 200 persons on their knees, beating their breasts, and bearing on their shoulders, as an additional penance, $\log$ s of wood of an enormous weight. Carli having given some exhortation, caused the candles to be extinguished, after which these pious persons drew out leather thongs, and cords made of bark, with which they continued to whip themselves for a whole hour without intermission. Our traveller here bursts into an ecstasy of admiration, and laments, that these "miserable Ethiopians" should thus put to shame European Christians, who, far from employing themselves in similar exercises, loaded with the opprobrious appellations of hermits and wry necks, those who paid a greater regard than themselves to the precepts of the church. To complete his satisfaction, the logs, after having duly pressed on the shoulders of this devout assembly, were left behind, to serve as fuel for the convent. 
After residing a short time; our author began to feel his health impaired by the influence of the climate. This would have affected him less; had it not been for some local annoyances to which he was exposed. The wall of his apartment being of fat ill-cemented clay, nourished a colony of very large rats. These treated him with no ceremony, and established indeed a sort of highway across his person, on which severe and frequent bites were consequently inflicted. The bed was moved to every corner of the room; but "these " cursed creatures always found him out." His next plan was to cause all his negroes to lie round. the bed on mats, like a species of body-guards. The rats, however, found their way over every impediment; and; as each of the negroes had "some "wild and disagreeable smell," their presence formed a serious aggravation to the evil. Under this complication of distress; he determined at length to lay the whole case before the Grand Duke. That prince presented him with a monkey, which was strongly scented with musk, and which was found sufficient to deliver him from all his evils. Its rapid movements deterred the rats from approaching; while the effluvia of the musk corrected the unsavoury odours which issued from his sleeping companions. After being freed from all these annoyances, however, he had nearly been overtaken by VOL. $x$. 
another still more serious. One night as he lay fast asleep, the negroes waked him by the exclamation of " out, out!" and, as he was unable to move, they laid hold of him, for the purpose of dragging him away. The father imploring to know the motive of such usage, they could only cry " the ants, the " ants." In fact, on looking downwards, he perceived his legs covered with those insects, who were making rapid progress towards his trunk; and before he had passed the threshold, the floor was overlaid with them to the depth of half a foot. The missionary was deposited in the garden, till a quantity of straw, being collected and set on fire, either consumed or drove away these formidable invaders. Carli then returned to bed; but the ants had left such a stench, as the most diligent use of the monkey was scarcely sufficient to counteract. He was assured, however, that, but for this abrupt removal, he would infallibly have been eaten up; and that cows were often found in the morning with nothing left but the bones, all the rest having been consumed by those insects. "God "be praised," says he, therefore, " that my body " was not devoured by them alive." *

* The ants by which our traveller was so grievously annoyed, are undoubtedly the insect properly called Termites, which abound prodigiously over all Western Africa. Golberry says, they might be called its scourge, if their extraordinary power 
Sickness, and these annoyances, at length overcame the long-suffering of Carli; and he determined to return to Europe. The journey to the coast was effected with much difficulty, as the negroes furnished by the Grand Duke conveyed him very carelessly, and at length entirely deserted him, so that it was only by high bribes, that he could induce the country people to carry him forward to the Portuguese settlement. After having recovered of his illness, he went on board a vessel bound for Brazil. But his sufferings were not destined to end here. The vessel was soon overtaken by a calm, the effects of which were on many accounts to be dreaded. The sailors therefore took the image of St Antony, and fixing it against the mast, warned the saint, that he must remain in that position, till he furnished them with a favourable wind. St Antony, not satisfied with his posture, granted a slight breeze; but this was inadequate to carry them on with the requisite speed. Provisions soon began to fall short; and at length they were threatened with the most direful extremities of famine. As soon as this transpired, the children began to cry for mercy; the women soon

of devastation were not employed in consuming substances that would otherwise prove noxious. He confirms the fact, that large animals, even elephants, if wounded, and unable to move, are often entirely eaten up in a very short time. 
joined them ; and at length the men " completed " the dismal harmony." The father thought this a favourable opportunity for reminding them of all their iniquities. It was no more, he remarked, than they well deserved, for the ill example which they daily set to the new converts. The chief cause, however, of the present distress, was doubtless the wrath of the Blessed Virgin, which had been justly excited by their having given her name to the end of a rope, with which they were wont to chastise the negroes; and he appealed to themselves whether such an application of ithad any tendency to evidence their belief in her as the mother of God. The mariners on having their sins thus clearly pointed out, burst into the most doleful lamentations, and implored the missionary to point out the means, if there were any, of appeasing our Lady, for so little respectful an use of her appellation. After some discussion, the father compounded for the repetition of a number of hymins in her honour, and the celebration of eighty masses. No very visible consequence followed; but they luckily discovered the coast of Brazil, before any considerable proportion of the crew had fallen victims to the privations under which they laboured.

In 1682, Francis da Monte Leone, a Capuchin friar, and a native of the kingdom of Sardinia, determined to undertake a mission to Congo. $\mathrm{He}$ 
readily obtained the sanction of the Holy See, and was allowed to take with him Jerome Merolla of Sorrento, a person animated with similar zeal. After a residence of several years, Merolla returned to Europe, and published a narrative of his adventures and observations. * $\mathrm{He}$ is very far from being an enlightened traveller; in credulity and superstition, indeed, he is equal to any of his predecessors. His narrative, however, contains some information, and presents curious pictures of the manners, and, above all, of the superstitions which prevail in this part of Africa.

Merolla, after touching at Brazil, and at the Cape of Good Hope, arrived at the mouth of the Zaire. Here the vessel encountered so violent a swell, as placed the missionary in extreme dread of falling a sacrifice to the watery element. Some fishermen indeed were seen on the shore, apparently ready to assist, and only waiting to be called upon, The missionary, however, suspecting that these were pagans, who by their sorceries might increase the fury of the tempest, shunned all aid from such a quarter. After infinite difficulty, he at length found himself in the channel of the river, when " his soul soon began to revive." The stream resembled a crystal causeway, and the shore on both sides scemed to be strewed with

* Originally published in Italian. A translation follows that of Carli in Churchill and Pinkerton. 
vegetable emeralds. As they rowed along its winding banks, they were continually shaded by a species of tree called Mangas, which resembled the royal laurel, and whose branches falling down, and striking root, spread so wide, as soon to convert one tree into a species of little wood.

The missionaries landed at Pinda, about twelve miles up the river, but finding the air unhealthy, they removed to Sogno, where the prince, whom they call Count, resided. Next Sunday, the Count having come to church in great pomp, Merolla celebrated mass, and delivered a short sermon. The subject was, "Thou shalt not kill ;" and, as of course the word kill frequently occurred, there always arose on that occasion a peculiar hum through the congregation, which became louder and louder every time that the critical word was pronounced. The Count alone maintained an immoveable silence. After sermon, Merolla and his superior "were in a thousand doubts about this humming." All whom they inquired at evaded the question; till at length they prevailed upon one to come to the house, when having treated him copiously with aquavitæ and roll tobacco, they at length extorted the secret. The Count, it seems, having entertained suspicions of a plot against his life, had put a number of the people under the hands of the magicians, to undergo the Bolungo. Several persons having fallen victims to this barbarous mode 
of trial, the word kill had suggested it to the audience, who raised the hum in token of suppressed approbation. The Bolungo consists in causing the suspected person to drink the prepared juices of certain herbs, which, if he is guilty, produce fainting, convulsions, and death ; but if innocent, prove totally harmless. The missionary very probably conjectures, that the magicians modify the draught, according to their good or ill will towards the individual. Merolla immediately hastened to the Count, and openly charged him with this inhuman and pagan proceeding. The Count did not harden himself in his iniquity, but "fell on his knees, weeping and lamenting like another David." He urged, however, that the test had been applied, not in the usual mode, but according to an improved and much superior plan of his own invention. The persons suspected had been made to bend over a large vessel full of water; when those who fell in had their heads struck off; while such as maintained their equipoise, were declared innocent. The missionary, however, having treated this system with equal reprobation, it was renounced, and all the orders to administer it countermanded.

Many other tests of this kind are, it seems, habitually employed by the magicians. One is afforded by passing a red hot iron across the leg of the accused person ; when, if it produced its natural effect of burning the part, he is concluded guilty. At 
other times, a soft and clammy root is put into the mouth, when, if it adheres, the person is forthwith punished, if otherwise, he is dismissed. Other trials are made by putting the arm of the accused into boiling water; by making him drink water variously prepared; or by applying snail shells to the temples; which, if they adhere, prove him to be guilty. Proofs are taken on a similar principle by the chiefs in the administration of justice. If two persons have a plea which is difficult to decide, a shell is placed on the head of each, and both are made to stoop; when the party from off whose head the shell first drops, has sentence immediate. ly given against him.

The magicians appear to have been resorted to universally in cases of malady, which proved a hard trial on the faith even of the steadiest converts. When their children or near relations were seized with illness, they immediately began to cast a longing eye towards their old method of cure; and if they had not recourse to it, they even incurred reproach among their neighbours, as suffering their relation to die, rather than incur the expence of a magician. Merolla's indignation was peculiarly roused by a certain lady of rank, who, he understood, not only performed magical cures, but wore dishevelled hair, and beat a drum before her, in sign of her profession. She had also a son whom she educated in the same arts. The missionaries 
instantly began a prosecution against these two persons, who, being warned, made their escape; but were so closely pursued, that they fell into their hands and were delivered bound to the Count. That prince, unwilling to proceed to the extremities on which the fathers were bent, caused them to be privately sent off to an island in the Congo. This drew upon him a violent invective from Merolla, who reminded him of the glo rious example of his predecessor, Count Stephen. That prince, whenever a wizard was discovered in the country, had his head "lopt off without fur" ther ceremony." It does not appear, however, that the misssionary ever obtained possession, for this purpose, of the two persons in question.

Besides these medical wizards, there was a higher class called Scingilli, who boasted the power of dispensing rain at pleasure, to whom prayers for that blessing were regularly addressed, and who claimed a portion of the fruits which their influence produced. Several of these persons openly defended to Merolla the usefulness, and even necessity of their vocation; demanding, what would become of the country, if there were no one who could administer that beneficent element? The head, or king of these magiciaus, is a person called Ganga Chitorne, or God of the Earth, to whom, accordingly, its first fruits are regularly paid. This person holds it impossible that he can 
die a natural death; on finding, therefore, that his end approaches, he transfers his power to a favourite disciple, and causes himself to be publicly put to death. It is impossible to express the anxiety of the inhabitants lest the office should be vacant, as in that case it appears to them, that the earth must immediately become barren, and the human race perish.

One of the forms in which the magicians exercised their power, was by imposing prohibitions which were not to be violated under the most dreadful penalties. On this head, a striking instance is given of the power of imagination. A young man had been thus prohibited from eating the flesh of a wild hen ; which, however, it so happened, that he one day did eat, supposing it that of a tame one. Four years after, he came to the same house, when a wild hen was again produced, which he declined on account of the prohibition. His host laughed, and assured him that he had formerly eaten the very same food; an information which acted so powerfully on the mind of the young negro, that he died in twenty-four hours.

Another frequent form of superstition, was that of the women binding their children with cords, which the magicians supplied as a preservation against all mischief; and to which, by way of double security, they added Agnus Deis, medals, and Catholic relics. Whenever any child was 
brought to be baptized, the missionaries made diligent search for these cords; and if any were found, instead of baptism, a smart whipping was administered. One poor woman being thus detected, began, with great simplicity, to excuse herself by saying, that of four cords which had been round the child, she had carefully taken off three, but had unluckily forgot the fourth. The amusement which this apology excited in the assembly, induced the missionary to remit the usual chastisement.

Merolla finding his utmost efforts to put down these superstitions insufficient, had recourse to an expedient which we cannot admire altogether so much as he himself appears to do. Having an image in relievo of the Blessed Virgin, he procured a dagger and struck it into her breast, then besmeared the body with blood, making it appear to have flowed from the wound. The missionary then began a long sermon against all their superstitions, dwelling particularly on the injury which they did to the Holy Mother; at the end of which, he drew aside a curtain, and exhibited to them the deplorable condition to which they had reduced her. At this spectacle, the hearts of the congregation were melted, and they burst into the most doleful cries and lamentations. Merolla was particularly edified by the conduct of one man, sho, having a wife and daughter whom he knew 
to be engaged in magical practices, ran home and beat them without intermission, till they agreed to come and make confession before the priest.

One custom, which seems peculiar to this country, was the mode in which marriage was contracted. Before forming any permanent engagement, the two parties lived for some time with each other, in order to make trial how far their tempers and inclinations agreed; during which interval, either party might, without the smallest reproach, dissolve the connection. The abolition of this system of trial, proved the hardest task which the missionaries had to encounter. In vain did they urge, that if their companions were agreeable, they ought at once to marry, or if disagreeable, to separate from them. A little longer time was still asked before a final resolution. Merolla complains, with peculiar bitterness, that the females were always the most determined upon having the benefit of this trial, and the most difficult to satisfy as to the result. All direct remonstrances having proved fruitless, he bethought himself of acting upon them through the medium of the mothers. Being, therefore, sent for to confess one, whose daughter he knew to be under trial, he positively refused absolution, until she had compelled the young lady to marry. The mother declared, that she would by no means hazard incurring her daughter's curse, by obliging her to form such an 
engagement, contrary to her own inclination. All arguments having failed, the missionary went next to the daughter, and roundly asked, if she was willing' " that her mother should go to hell upon " her account." The poor girl fell into a violent fit of trembling, and declared, that she would take the first opportunity of marrying, which she accordingly did. But, in general, both parties were equally intractable, and the mothers, in particular, positively refused to take any concern in abridging the period of their daughters' trials. One of the missionaries, indeed, Father Benedict, applied himself most diligently to the task of "reducing stray" ed souls to matrimony." Accordingly, he succeeded with no less than six hundred; but it was "laborious work;" and he fell, in consequence, into an illness, which soon proved fatal. After so unfortunate an issue, no future missionary seems ever to have embarked in the cause with the same ardent and effectual zeal.

After a considerable residence in Sogno, our author made an excursion into the territory of $\mathrm{Ca}$ congo, situated on the northern side of the Congo. This was an expedition attended with considerable danger, as the sovereign and chief men of that country still adhered to their ancient idolatry. One of the ancestors of the present king had fallen a sacrifice to an attempt to introduce the Christian religion into his dominions. It was only a very 
imperfect and perilous toleration, therefore, which the missionaries and their converts enjoyed. As the prince, however, had married a daughter of the count of Sogno, hopes were entertained that he might either be gained over, or might at least allow the missionaries to reside and carry on their operations unmolested.

Merolla crossed the Congo, and went first to Capinda (Cabenda), in the province of Angou. Greatly as he had been scandalized by the conduct of professing Christians on the south of the river, his horror was much greater, when he found pagarism reigning in full dominion. One of the first objects which met his eye, was the administering of an oath, which, to render it more binding, was taken in presence of their idol. This object of adoration, he compares to a mountebank's merry-andrew, " having a divers coloured vest on, a " red cap on its head, and standing on a little ta. "ble." Almost all the houses had such idols, five or six feet high, in front of them. At the time of new moon, they fell on their knees, calling out to that luminary, "So may I renew my life " as thou art renewed." Passing one day in the fields, our author saw the natives busily employed in invoking evil spirits. The place was a wretched hut, built on a small rising ground, and upon one side of which hung two dirty aprons. In the midst of the hut was a mud wall, two feet high, 
behind which stood the wizard, "to pronounce "the fallacious oracles of the prince of darkness." The missionary having armed himself with the sign of the cross, was preparing to enter, but heard so loud a murmur among the crowd at this attempt to intrude into their " hellish tabernacle," that he deemed it prudent to retire.

The houses are built of reeds, and are such miserable huts, that they appeared to our author only fit to receive the insects with which the country abounds. The palace and governor's house, however, though built of the same materials, contained several handsome rooms, and the walls were hung with mats, made of a delicate kind of ozier; and two brass guns, obtained from Europeans in exchange for ivory and slaves, were mounted upon it. It appeared ridiculous to our author, that houses built of "straw, stakes, and oziers," should be defended by brass guns. Merolla was invited to visit the king; but understanding that he wore enchanted bracelets, and other magic charms on different parts of his person, he declined the honour.

As Merolla was on his way to the northward, he received a message from the king of Congo, earnestly entreating a visit, as many years had elapsed, since a Capuchin friar had been within his dominions. Such an invitation, from the most powerful monarch of that part of Africa, was not to be rejected. Our traveller, therefore, determined 
to recross the Zaire, and proceed to the capital of Congo. He proceeded to Bomangoi, where he hired a boat to convey him up the stream. He found the voyage extremely painful from the excessive heat, and from its being the season of the rains, (March): During the night, he was obliged to sleep on the shore upon the wet ground, where he was tormented by a species of gnats, which he compares to horse-leeches, as they never quitted their hold till they burst. At length he arrived at Boma, a large and populous island in the Congo. He was received, not very courteously, by the Mani, who admitted him indeed into his presence, but on condition that no contact should take place, lest it should destroy the virtue of the numerous enchanted brass and iron rings with which he was covered. The prince was also displeased with his refusal to baptize a female slave, with whom he lived on a very intimate footing. In the evening, Merolla was seized with violent pains in the bowels, which convinced him that he had been poisoned; though there does not appear, in the symptoms and circumstances, very much to favour such a supposition. In a few days he was entirely recovered, and sent to the Mani to request a boat. That officer replied, that if Merolla stood in need of a boat, he himself was in equal need of a cloak. In this remark there was nothing obscure to $\mathrm{Me}$ rolla, who was aware that the prince knew him to 
be possessed of two handsome pieces of cotton cloth. He therefore sent one, stating, that the other was reserved for the service of God. The prince returned for answer, that the boat also was for the service of God: so that our traveller had no resource, but to deliver up both the pieces. The accommodation for which he was compelled to pay thus liberally, consisted merely in ferrying him over from the island to the southern shore of the Congo.

Merolla now proceeded by land to the capital; but the weak state of his health made the journey laborious. On the second day he came to Norchie, which appeared to him the finest situation he had seen in Ethiopia. The inhabitants also came in crowds to be baptized; so that space being wanting in the house, the Mani invited him to go to the church. Delighted to hear that there was a church, he immediately repaired thither. The aspect of the door had something which did not altogether delight the eye of Merolla; but when this door was thrown open, a spectacle presented itself, which made his hair stand on end. Instead of an altar, was a heap of sand, in which horns of different sizes were stuck; while on one side hung two coarse aprons, similar to those observed at the scene of the magic invocation. The sight of these objects excited such outcries from the missionary, that the Mani and all his train took to flight with the utmost expedition. His first impulse was to set fire to the edifice; vol. I. 
but considering, that the whole town would pros. bably be consumed in consequence, and that he might thus draw upon himself the vengeance of the inhabitants, he contented himself with following and loading them with the bitterest reproaches, adding, that not one should be baptized till they had overthrown the execrable Cariabamba, for such was the name given to the tutelary idol of this pretended church.

Merolla was not now long of reaching the capital, where he was introduced to the sovereign, and very courteously received. After the first compliments were over, the missionary began to inquire the motive which had induced the king to wish so very earnestly for this visit. The king replied, that he wished to have a preacher of the gospel within his dominions. Merolla asked if there were not some other motive; and, receiving no answer, added : "I fancy you sent for me, to put the crown " of Congo upon your head." The gracious smile of the prince, and the murmur of applause from the courtiers, fully confirmed the presentiment of the missionary. The crown of the kings of Congo was then, it seems, in possession of the Portuguese, a circumstance of which our author gives the following explanation.

A prince of the name of Don Antonio, having: ascended the throne of Congo, embroiled himself in a war with the Portuguese. He is described as a monstrous tyrant, and the sole aggressor; yet it 
transpires, in the course of the narration, that the Portuguese took arms to find " those gold mines " which the Congolans had long promised," though none such were probably in existence. The king is said to have mustered 900,000 men ; doubtless an immense exaggeration. Accordingly, on coming to battle, he proves not to have above 80,000 . The troops opposed to him did not exceed 400 Europeans, and 2000 negrroes. He was soon able, by his multitude, to surround them; and seeing a woman and child standing by the general, called out to his troops, that they would gain an easy victory over an army fettered by such encumbrances. The monarch little suspected, that the female whom he beheld was the Virgin Mary, whose presence secured victory to the Portuguese. His army, accordingly, was totally routed, he himself killed, and his crown and sceptre fell into the hands of the victors. In this manner the Portuguese had those ensigns of royalty to dispose of, which Merolla, accordingly, succeeded in procuring for the king.

The missionary did not remain long at the capital; but, notwithstanding the entreaties and reproaches of the king and queen, took his leave, and returned to the coast. 'The state of his health soon. after induced him to return to Europe.

Besides narratives of travels and adventures, several works have been published, which merely 
professed to give a description of Congo, and the neighbouring countries. The first was by Edward Lopez, who, after having resided for some years in that country, was, in 1578, sent thither in the character of ambassador. He did not reach his destination; but was driven, by contrary winds, on the coast of Cumana, where he was detained for a long time, and found it at length expedient to make his way back to Portugal. Here he met with an Italian, of the name of Pigafetta, to whom he communicated his papers, and gave a variety of oral information. Pigafetta then composed under his eye a description of these regions, which he translated into Italian, and published in that language. * Lopez himself set out immediately after for Africa.

The father, John Antony Cavazzi, went as a missionary to Congo in 1654, and remained there twelve years. On his return, he gave a report of his observations, which was revised and published in 1668 , by a Bolognese preacher, of the name of Alamandini. Labat has translated, and made it the basis of his Relation Historique de l'Ethiopie Occidentale, published at Paris in 1732.

In 1776, the Abbé Proyart published at Paris a history of Loango, Cacongo, and other kingdoms

* Partly translated by Purchas, but more completely in Osborne's collection. 
in Africa. It is compiled from materials furnished by recent missions to that country. *

To analyze historical descriptions of this nature, now in a great measure obsolete, would, it is conceived, be inconsistent with the plan and limits of the present work. Our object is rather to exhibit the steps by which discovery was carried on, and to combine views of the country and manners, with the adventures of the travellers who made the observations. 'We have, however, in the course of this chapter, made use of the remarks contained in the works now alluded to, wherever they appeared to throw any light on the subject under consideration.

The following narrative $t$ is by an Englishman, and does not follow exactly in the order of date; but, as it relates to regions conterminous with those traversed by the missionaries, whose track we have been following, it may be advantageously introduced as a supplement to their information.

About the year 1590, a Portuguese vessel, having on board an English prisoner, of the name of

* Translated in Pinkerton's Collection, Vol. XVI.

† First published by Purchas, II. 970-985. Reprinted by Pinkerton, Vol. XVI. 
Andrew BatTel, touched upon the coast of Benguela, for the sake of procuring slaves. Near the Morro or Cliff, they saw on the coast a great body of men assembled, and being curious to know who they were, went on shore in their boat. About five hundred of the party came up, and informed them that they were the Gagas (commonly called Giagas), who had come from the Sierra de Leone, through Congo and Angola, and that they were ready to trade with them for slaves. In the course of seven days the Portuguese laded their ships with that commodity, paying a rial for one, which, elsewhere, would have cost twelve milreas. So excellent a bargain seems to have subverted all moral and humane feelings in this crew. They readily agreed to ferry the Giaga army over the river Cona, for the avowed purpose of carrying fire and desolation into the territory of Benguela. Before crossing, the general caused his Gongo to be sounded, and made an oration, so full of courage and vehemence, as our author marvelled much to hear, " among such heathen people." Animated by this speech, the Giagas rushed to the river with such impetuosity, that it was necessary to employ force in order to preserve order. The Portuguese ferried them over by eighty at a time, and covered their landing by a discharge of fire arms. The Benguelas, less warlike, were completely routed,their prince slain,-many taken prisoners, -and 
the dead bodies devoured. The Giagas continued for five months to ravage Benguela, during which time the Portuguese repeatedly came back to drive a trade equally profitable as at first. In their last voyage, they found the Giagas departed; an event for which they were inconsolable, as there was no other race, whom it was possible to defraud to such an extent. They determined, therefore, in defiance of every danger, to follow them into the interior of the country, where they at last found them under the command of a new lord, called Mofarigosat. Here, however, they were caught by their own prey; Mofarigosat, being about to engage in a great war, insisted upon their accompanying and assisting him with their fire arms. They found no alternative but to consent; but, on the termination of the war, petitioned so earnestly for leave to depart, that they obtained it, on condition of leaving one of their number in pledge for their return. Battel, being an Englishman, was pitched upon by his companions as the most convenient person to fill this situation. $\mathrm{He}$ was well treated until the period aryived when the rest of the party had stipulated to return s but when it was found that they were paying no regard to their engagement, rigorous measures began to be adopted. The majority were for putting him to death, but the chief protected him; and at last they ended in allowing him to depart. Left to 
himself, however, he was totally unable to find his way home; and, after wandering for some time, was fain to return to the camp of the Giagas. This voluntary arrival seems to have given him favour in their eyes ; and he was well treated four months, which they spent " continually triumphing, drink"s ing, dancing, and eating men's flesh." At length, their roamings having brought them to the neighbourhood of a Portuguese settlement, and the wizards having announced it as the devil's pleasure that Battel should depart, he found no difficulty in effecting his safe removal, along with some slave merchants who came to the camp.

The Giagas are described by him as a race of organized out-laws, who have neither country, possessions, industry, nor arts of their own ; " depending " on war for a supply of all they want." Wherever they come, complete desolation attends them; they reap the corn without sowing any in its place; and, instead of cautiously extracting the juice of the palm trees, they cut them down and leave them to rot. He confirms the report, that, in this community, no children are permitted to live; but are buried alive as soon as born. They keep up their number entirely by taking the boys and girls, at the age of thirteen or fourteen, from the places they have conquered, training them to all their roaming and predatory habits. "They make "war," says the writer, "by enchantments, and 
"take the devil's counsel in all their exploits." Before beginning their march, an augury is performed in the most solemn manner. The great Giaga sits on a stool, surrounded by a multitude of wizards and women. The wizards then take a white powder, with which they paint over his forehead, temples, belly, and breast, accompanying the operation with "long ceremonial and enchanting "speeches." At length the wizard brings the great Giaga's Casangala, a weapon resembling a hatchet, and bids him be strong, for his mokisso is with him. A male child is then brought before the Giaga, which he kills, and immediately sets out, in full confidence of overcoming his enemies. Their discipline is very severe, and those who have turned their backs on an enemy, are immediately put to death. When open force fails, they have recourse to ambuscade; by their superior skill in which, they seldom fail to prevail in the end.

The Giagas are also mentioned by Lopez, who describes them as inhabiting the mountains behind Congo, and particularly about the lake which gives rise to the Zaire. In the time of a king, whom he calls Don Alvaro, they made an incursion into the kingdom, and swept all before them. The king sought refuge in an island of the Congo, where he remained till the Giagas had consumed every thing that was to be found in the kingdom, and were constrained to seek elsewhere for other 
booty. Merolla says he saw, without the capital, shambles, where human flesh had been sold by them, while they occupied that place. They offered it liberally, he says, to the Portuguese, who came to trade with them; but the latter rather wished the captives as slaves, "than to have their " bellies filled with such barbarous food,"

M. Degrandpre, an officer in the French marine, who spent the years 1787 and 1788 on the coast of Africa, published on his return the result of his observations, under the title of Voyage a la Cóte occidentale d'Afrique, Paris, 1801. This work does not contain any narrative of travels or adventures; but merely a general description, and that chiefly of the coast, for he appears scarcely to have penetrated at all into the interior. It is, however, by much the most recent, and probably the most authentic description, being the only one which has not passed through the hands of the Romish missionaries. As it is besides scarcely known in this country, a short abstract of its contents will, we conceive, be interesting.

The coast of all this country is, in commercial language, called generally the coast of Angola. From Cape Lopez Gonsalvo to St Philipe de Benguela, it includes a range of nearly twelve degrees; the former of these places being in $0^{\circ} 44^{\prime}$, and the latter $12^{\circ} 14^{\prime} \mathrm{S}$. lat. Congo, however, is throughout the name given to the people; who, as to lan. 
guage, manners, and government, are entirely similar throughout the whole of this extensive region.

There are two routes, by which, after passing Cape Verd, vessels may reach the coast of Angola. One consists in turning to the east, and following the coast, till they reach Cape Lopez Gronsalvo. This is the most direct line, and when circumstances are favourable, makes by much the speediest voyage; but vessels are liable to be detained for a very long time, by unfavourable currents. The other route is by sailing south-west, till they almost touch the coast of Brasil, when a favourable wind and tide carries them directly across to Congo. This route necessarily occupies a considerable space of time; but it is liable to no casualty; and its duration may be calculated almost to a day. The first route is generally preferred, the sailors insisting, that its only danger is, they may possibly be detained as long by it, as they will certainly be by the other. Degrandpré is rather of a different opinion; having known voyages protracted, by adverse currents, to a very inconvenient length.

The soil of Congo is hard, compact, heavy, and extremely fertile. All the country, whether mountain or plain, is equally composed of earth, covered with the most luxuriant verdure. Our author pierced it at various points, to the depth of six feet, in the view of discovering rock or stone, but always without success; so that no country can af- 
ford so little scope for geological observations. He did not discover any shells or fossil remains of animals; he could not, however, dig to such a depth as fully to ascertain that none existed. The climate is superb ; it is never subject to hurricanes, or even to violent winds; vessels lie in perfect safety on the open coast; the rains have no fixed season, and are never so abundant as to prove injurious.

The fruits, which grow wild in this region, are equal in flavour to those which in Europe are reared with the greatest care. The citron, the bitter orange, the anana, the pirento, even sugar cane, spring up in the woods without culture. The coco, the yam, and the potatoe, are also produced in abundance. The soil is cultivated only around the villages in little spots, which may rather be called gardens than fields; the rest of the country is covered with large herbs that rise eight feet high, and render it almost impossible to penetrate. Here is a tree called mapou, which the author conceives to be the largest in nature. All the seamen of a vessel, holding each other by the hand, were unable to encircle one of them. The author, however, cannot conceive the design of nature in forming this tree. Its fruit is bad; it yields no shade; and the wood, of a spungy texture, has no use to which it can be applied.

The domestic animals of Europe, although transported in great numbers, have never multiplied in 
Congo; probably through negligence in rearing them. All the wild animals known in Africa are numerous here. Elephants, however, do not appear much on the coast; the ivory brought down the Congo, in large quantities, is from the interior. The insects called termites, are very numerous; also the whole ape and monkey race, particularly the oranoutang. The facts which our author certifies with regard to the intelligence of this animal are iruly astonishing. One, which was on board the vessel along with him, lighted the oven, proportioning the fuel to the temperature of the weather, and guarding against any of the coals falling out. It then advised the cook, by a sign, when it was time to put in the bread. It assisted also in pulling the ropes of the ship, knowing perfectly when to draw, and when to stop. It walked on its hindfeet, sup ported by a staff; and was supposed by the negroes to refrain from speech, only from the dread of being compelled to labour.

The houses of this country are merely cottages, composed of reeds, mud, and straw. Persons of distinction have a great number of these cottages, separate buildings being employed for kitchen, stable, and other offices, and one being appropriated to each of their wives. Before every cottage is an open space, where the master receives visitors, who are never introduced within doors. The whole are enclosed within a wall, composed of the 


\section{DISCOVERIES OF THE PORTUGUESE.}

same materials as the houses. A city consists merely of a collection of such enclosures, arranged without the smallest regard to order, and, instead of streets, narrow footpaths lead from one enclo. sure to another. The city of Loango, which is four leagues in circumference, does not contain more than 500 of these enclosures. It has, how. ever, 15,000 inhabitants.

The lsing's authority is absolute, so far as law is concerned, and is limited only by the difficulty of finding persons who are willing to obey it. A prince, a governor of a town, or even a large proprietor, called here suzerain, is often in a condition to set the royal will at defiance. Rank, as in some other rude forms of society, is transmitted exclusively by the female line. The throne descends not to the king's son, but to his nephew; the sons of princesses alone are princes-born, who form the highest rank in the state, and the only class who cannot be sold into slavery. By an iniquitous privilege, every rank may sell into slavery persons of a lower rank; so that the princes-born may sell every description of their fellow-subjects. Our author mentions a singular instance, in which, of two brothers, sons of one of the most distinguished men in the kingdom, one was sold into slavery, the other became king, both in consequence of their birth.

The princesses enjoy very peculiar privileges in 
regard to the married state. A princess may select at pleasure any individual as her husband; there rests with him no right of refusal. However. old or ugly she may be, he must instantly accept; must dismiss all his other wives, and confine himself wholly to her; he must even, if possible, avoid ever seeing another woman. She, on the other hand, can indeed have only one husband at a time ; but she is at full liberty to change him as often as she pleases, and without any reason assigned. It is very common to choose a rich husband, spend his whole fortune in a short time, and then throw him off for another. In this case he returns to his orid ginal rank, whereas, if the union had been dissolved by her death, he would have remained a prince for life. This has rendered, not unfrequent, the practice of administering poison to the royal consort; by which the husband both rids himself of a tyrannical helpmate, and secures the permanence of his own dignity.

M. Degrandpré seems to consider every attempt yet made to spread Christianity in Congo as altogether abortive. He contradicts, however, the report, that human flesh is eaten by the natives. The flesh of criminals, indeed, after execution, is cut into pieces; but it is merely exposed, to be devoured by birds of prey. It may be observed, however, that he never penetrated into those regions in the depth of the interior, to which this reproach has been exclusively attached by the missionary travellers. 
As the course and origin of the Congo has excited such extraordinary interest in Europe, it may not be improper to bring into one view the views, however imperfect, which the early Portuguese writers have given upon the subject.

All descriptions agree as to the impetuosity of the stream of the Congo, and the vast mass of water which it pours into the ocean. Lopez and Merolla represent the breadth at its mouth not to fall short of twenty-eight miles. Cavazzi, however, gives only three leagues, which nearly agrees with ten miles, Mr Maxwell's estimate. The rapidity of the current is such, that no advantage of wind and tide can enable any vessel to make head against it. The ascent can be effected only, by first keeping close to the shore, and then getting under shelter of one of the numerous islands which lie at its mouth. In proceeding upwards, there occurs a continued succession of such islands, each of which, for a certain space beneath, breaks the force of the stream, so that those who are well acquainted with the river, will always find a channel which they can navigate, without encountering its entire force. At 120 leagues above its mouth are found the falls or cataracts, which are nowhere particularly described. They are said, however, to be of great magnitude, and their noise so tremendous, as to be heard at the distance of eight miles. About seventy miles higher, near the city of Concabella, there appears, according to every report, to be a great union of 
rivers, flowing from different quarters of the interior. D'Anville, in his map, (1731) remarks, that the origin and early course of all these streams is involved in very great uncertainty. The early accounts, making them rise from the lakes of Zaire and Zambre, which also give rise to the Nile, are evidently fabulous, and founded on an erroneous system of African geography. The only statement at all distinct, is that given by Labat, chiefly from the report of Cavazzi. According to him, two of these great rivers, the Coango and Berbela, have their rise in or near the kingdom of Matamba, and, flowing southwards along the eastern frontiers of Congo, at length unite and take a westerly direction. D'Anville, whose authority is certainly better, makes only one river, instead of two. He gives it the name of Coango, but it has since been generally called Berbela. The next river is the Vambre, or Umbre, said to flow from east to west, through the kingdom of Fungeno, a region known only by name. The last and most northerly is the Bancaro, described as flowing through the kingdom of Anziko, which lies to the north-east of Concobella. This evidently must be the river, if any, which forms the yet unknown termination of the Niger, and to trace its course upwards, must therefore be the main object of European investigation. 


\section{CHAPTER III.}

\section{DISCOVERIES OF THE FRENCH:}

French African Companies.-Jannequin._First voyage of Brue; the Siratik._-Second voyage of Brue; Gallam; Accounts of Bambarra and Tombuctoo.-Third voyage of Brue; the Gum trade...Compagnon; Bambouk; its Gold mines._Adanson._Saugnier.

$F_{\text {RANCE }}$ was not among the nations which distinguished themselves early in the career of maritime discovery. The intestine broils by which she was long distracted, and her deep involvement in the politics of continental Europe, engrossed almost entirely the attention of her rulers. While the fleets of Portugal, of Holland, and of England, had explored and colonized the shores of the most distant oceans, France could scarcely boast a possession beyond the limits of Europe. Louis XIV., however ambitious of greatness of every description,

* Some of the English voyages up the central rivers were earlier than any undertaken by the French. But it seems better to reserve them till the following chapter, when they will become connected with those recent travels in the inte. rior, which have been all performed by the English nation. 
made incredible efforts to raise France to the rank of a maritime power. Under his reign, establishments were formed both in the East and West Indies; the splendour of which soon rivalled those of any other European nation. Amid the various objects which attracted his attention, the shores of Africa were not overlooked. They were interesting in a double view; as afiording a supply of slaves for the cultivation of the West India colonies, and, still more, as being, with the single exception of Spanish America, the only country which had the reputation of producing gold, an object of trade to which, at that period, every other was considered as secondary. When governments at that era had determined to encourage any branch of commerce, the only mode which occurred to them was to erect a company, with the exclusive privilege of carrying it on. A private company at Rouen had established a factory at Dieppe, where they traded on a small scale, but with profit. They were obliged, however, by royal authority, to sell the whole of their concern to the new association, which was established under the title of the West India Company. They began their operations in 1664 , were supported by the whole weight of ministerial protection, and received every aid from the fleets and armies of France; yet, in the course of nine years, they went entirely to wreck. Their privilege and chattels were purchased by a second 
company, which confined its operations to Africa alone. In eight years, this also was in a state of such total bankruptcy, that its creditors thought themselves happy in recovering one fourth of the sums due to them. On their ruins was erected a third, which speedily shared the same fate. It might have been supposed, that this downfal of company after company, would at length have opened the eyes of government to the error of the system upon which they were acting; and that some trial would have been made, of the efforts of free commercial intercourse. No such idea ever occurred; nor, on the ruin of one company, did any remedy suggest. itself, except the immediate erection of another. A fourth was accordingly erected, which, by great diligence, and by a judicious choice of its agents in Africa, was enabled to keep itself afloat for fifteen years, after which it sunk like the rest. It was succeeded by a fifth, which expired in eight years. The undertaking was then absorbed by the Great Mississippi Company, which undertook to carry on at once the commerce of America, of Africa, and of the East Indies. After that mighty bubble had burst, the system of exclusive companies, so far as related to this quarter of the globe, was at length relinquished; the territories were taken under the administration of the crown, and the trade was left free to all the subjects of France. 
Notwithstanding the rapid downfal of these successive companies, each, at its commencement, had a period of hope and activity, during which vigorous exertions were made to extend the channels of its commerce. The French, therefore, in the course of the eighteenth century, penetrated deeper into Africa, and obtained more information respecting the most interesting portion of its interior, than any other European nation ; and they maintained this pre-eminence till the splendid exertions of the African association enabled that body to outstrip all former competitors. Among French discoverers, the most active by far was the Sieur Brue, who had the management of African affairs under the fourth company. The narrative of his various journeys, though not published by himself, is preserved by Labat in his Afrique Occidentale. There exists, however, one relation of a journey, performed at a prior period, (in 1637) by Claude Jannequin, who deserves notice, as being the first Frenchman who penetrated into the interior of those vast regions.

Jannequin was a young man of some rank; but happening, as he walked on the harbour of Dieppe, to see a vessel bound for Africa, he was seized with the most ardent desire of visiting that distant region. He immediately engaged himself as a soldier, and set sail. After touching at the Canaries, the crew landed on the coast of the Sahara, 
to the north of Cape Blanco. Their object was to construct some small barks, which are necessary in navigating the river of Senegal. Why they chose this place for such an operation, our author did not fully comprehend; but he was struck with horror at the aspect of desolation which the tract every where exhibited. The soil consisted entirely of sand, so soft, that it sunk beneath the feet, and marle it impossible to walk above fifty paces at a time. To whatever depth they dug, not a drop of water was ever found. The inhabitants, who resembled skcletons, rather than living beings, fled at the sight of the French, and could by no invitation be induced to approach. After various ineffectual attempts to procure their fish in exchange for European goods, the following contrivance occurred: The French laid down a certain quantity of goods, and then retired; upon which the natives, entering into the plan, came, took up the goods, and deposited in their stead a quantity of fish; after which they took to flight with the utmost precipitation. At length, to the great joy of our traveller, the vessel left this inhospitable shore, and proceeded to the mouth of the Senegal. It was left at anchor near the bar, and the greater part of the equipage proceeded up to the village of Biyurt, where they landed. The French had then no settlement upon the river, so that their first operation was, with the assistance of the 
natives, to erect huts, which might shelter them from the pernicious influence of the air. Slight as the structure was, it constituted a severe labour to men unused to the climate, and left, while the building went on, unsheltered beneath the influence of a burning sun.

As soon as the arrival of an European vessel became known, ambassadors repaired thither from the Damel and the Brak, the two most potent sovereigns in this part of Africa. Presents were exchanged, and commercial arrangements speedily agreed upon. The party then began to ascend the Senegal. They were struck with admiration at the perpetual verdure which reigned upon its banks, and the beautiful trees by which they were adorned. All the forests were filled with echoes, which the author ascribes to the depth of the surrounding solitude. The trees, however, shooting out a number of small roots from the trunk, rendered the ground almost impervious. Whenever they came to a village, the chiefs gave them a hearty welcome, and the inhabitants came out with alacrity to trade. The principal monarchs, through whose territory they passed, were the Damel, king of the Jalofs; the Brak, king of the Foulis; the Kamalingo, king of the Moors of Barbary; and the Samba Lamma, whom he terms king of the Moors and Barbarians, and whose territory is said to have 
extended as far as Tombuctoo. The two last states were evidently the Moors of the Sahara, inhabiting the northern bank of the Senegal. The author, to prove the agility of these people, mentions an extraordinary exploit of the Kamalingo. That chief undertook to vanquish a lion in single combat. To view this spectacle, the French were mounted upon high trees, at a safe distance from the scene of encounter. He then mounted on horseback, armed with three javelins and a Moorish cutlass, and actually performed the exploit, sustaining only a slight wound in the thigh. Jannequin seems, on the whole, to have been much struck with the strength and individual courage of the negroes; and declares that, with one hand, they were more than a match for the strongest European. He seems to have been impressed with peculiar awe, by the close intercourse which they were understood to maintain with a supernatural being, whom he terms the devil. That personage, it seems, was accustomed to assist the Marabouts in teaching them to read; a faculty which, without his aid, they could never have acquired. He performed a less agreeable, but equally useful office, in making regular reports of all the acts of theft committed by any of the natives.

In treating of the external appearance of the Mandingo negroes, Jannequin asserts, that their flat noses and thick lips are produced by artificial 
pressure, both being considered as the highest possible ornament. This report, however, differs from that generally given by travellers. The species of shirt with which they cover themselves, he compares to the surplice worn by the Catholic priests, and their bonnet to the cowl of a Capuchin monk. The chief embellishment is bestowed upon their hair, which, in the higher ranks, is entirely covered with ornaments of coral, gold, and glass. Another article most copiously worn is that of grisgris, or charms; the consumption of which is only bounded by the means of purchase. The bodies of the chiefs are so encumbered with these defences, that they are often unable to mount on horseback withou't assistance. 'These grisgris, however, in consequence of enveloping them so completely, actually form a species of panoply against hostile weapons. They consist merely of pieces of paper, covered by the Marabouts with Arabic characters ; but the purchasers carefully wrap them in cloth, or even inclose them in cases of gold and silver. There are grisgris against the danger of drowning,-against wild beasts, -against warlike weapons, - -against every object, in short, which can be a cause of dread to the human mind; and, it is said that a negro, thus armed, will expose himself to every form of death, without the slightest apprehension. It may easily be supposed that, for the Marabouts, to whom it costs nothing, the ma- 
nufacture must constitute a most lucrative occupation.

The form of Mahometanism, established annong the negroes, is, in many respects, imperfect. Instead of praying five times a-day, according to the practice of the Turks, and other zealous followers of the prophet, they confine themselves to three. The priest, or Marabout, assembles the village at the stated times for the performance of this ceremony. The people range themselves behind him, with their faces turned towards the east, and faithfully repeat after him every word, and imitate every motion and gesture. Jannequin was particularly struck with the rigorous manner in which their fasts were observed. While the Ramadan lasted, no urgency of the Europeans could induce them to taste a morsel till the close of the day. The most devout considered it a sin even to swallow their spittle, and kept their mouth carefully guarded with a cloth, lest any flying insect should enter. When evening arrived, however, they were anxious to indemnify themselves for this temporary privation, and spent the night in feasting, drinking, and dancing.

Jannequin reports himself to have ascended the Senegal seventy leagues, as far as the district called Terrier Rouge. He entitles his work a "Voyage to Libya ;" yet appears sensible that the term Libya can, with no propriety, be applied 
to the region through which he travelled; but he asserts, that it had been the practice of navigators, for two centuries, to name this coast "Maritime "Libya." His geography of the interior deserves little attention; as it is derived, not from any in. formation which was, or could be collected by himself, but from the popular belief which happened at the moment to prevail in Europe.

From the time of Jannequin, there is no record of any French discoveries in the interior of Africa till that of BRUE, who, in 1697 , went out to take the principal direction of the Company's affairs on the Senegal. These had fallen into a deplorable condition, in consequence of the frauds and malversations of its agents, and of the quarrels in which they had involved themselves with the principal sovereigns on the river. In consequence of this misconduct, it required all the efforts of an able and prudent governor to retrieve the affairs of the Company ; and the choice made of Brue seems to have been highly judicious. In fulfilment of the proposed object, he made repeated voyages up the Senegal, and procured a great accession to the knowledge which his country then possessed respecting this part of Africa.

Brue set out on his first voyage on the 28th July 1697, from Port St Louis, where the French had now established a factory. His object was to visit 
the king of the Foulis, called the Siratik, to accom modate the disputes that had arisen with him, and thence to proceed up to Gallam, where he wished to establish a factory. He was accompanied by three vessels and several small shallops; one of which, with two canoes, went before, to announce his arrival. In sailing up the Senegal, he was wonderfully struck with the beauty of the scenery on its banks. The rainy season having just terminated, the woods and meadows were clothed in the most luxuriant verdure. The forests resounded with the songs of innumerable birds, while the prodigious multitude of the various monkey tribes, which leaped from branch to branch, presented a lively and amusing spectacle. The French passed several small islands formed by the waters of the Senegal, and which are entirely overflowed during the rainy season, but occupied and cultivated as soon as the waters have subsided. They came then to a much larger one, called Morfil, or the Isle of Ivory. It derives this name from the multitude of elephants by which it is peopled. These go in herds of forty or fifty, and are quite harmless as to the inhabitants, but often do serious injury to the plantations. The negroes take them by digging pits in the ground, which being covered with leaves and branches of trees, the elephants fall in, and are then easily killed with arrows.

Near the western extremity of this island, on 
the north of the river, is a district called Terrier Rouge, celebrated for the gum trade. This is carried on to a great extent with the Moors, who. collect it from the forests on the borders of the Sahara. The meadows are rich, and covered with innumerable herds; but, during the rainy season, the Senegal inundates this district, and the inhabitants are obliged to withdraw for safety into the most elevated spots. Thence the expedition proceeded to Hovalada, a considerable village, still on the same bank of the Senegal. Here Brue began to traffic for cattle, of which the neighbouring meadows afforded an abundant supply. The most convenient medium of exchange was brandy, for one pint of which a fat ox was considered as only a fair equivalent. Brue decidedly recommends brandy as at all times the most acceptable and profitable merchandise which can be carried into Africa. He observes, however, that no bottle ought ever to be presented to an African, which is not completely full. The negroes, probably from dread of imposition, view, with peculiar jealousy and disdain, every vessel from which any portion of this precious liquid has been subtracted. He asserts, that they prefer a small vessel, full, to a barrel, of which even an inch of the depth should remain vacant.

At the termination of the isle of Morfil, is the isle of Bilbas, formed in the same manner, and of 
a character entirely similar. Brue now received a message from the Siratik, expressing desire, and even impatience, to see him. For these sentiments, the Director gave him full credit, having announced his intention of paying up all the dues which had been withheld by his predecessor. He came next to Kahaydé, a place of considerable trade upon the river. Here he was visited by the chief, who was well mounted, and followed by a retinue of about twenty attendants, handsomely equipped. His wife, daughters, and female slaves, accompanied him, mounted upon asses. The particulars of the interview are not given, but some trade, though not very satisfactory, appears to have been carried on. Of the monarchs of Africa, our traveller here remarks in general, that European beggars, whatever effiontery they may possess, might derive important lessons from the example of these princes. Every gift bestowed, instead of appeasing their cravings, is considered only as affording an opening to demand something more. After all forms of request have been exhausted, borrowing is resorted to, but with the firm determination of never repaying. When any of these multiplied petitions are rejected, the prohibition of commerce, or at least the loading it with new imposts, is the invariable resort. The worst of all is, when an African makes a present, for in this case, by immemorial usage, he conceives himself 
entitled to a return of at least double or triple the value; so that articles are procured much more cheaply at the most disadvantageous market, than by being received as presents.

While the French Director remained at Kahaydé, he received a second message from the Siratik, urging him, with the same earnestness as before, to repair to his residence. A sail of two leagues brought him to Ghiorel, a port belonging to that prince. Here he was visited, the same evening, by one of the princes, called Buckar Sire. Mutual presents and compliments were exchanged, and the young prince assured him, that his reputation alone was sufficient to secure him a welcome at his father's court. Soon after appeared a still more important personage, the grand Bouquenet, an old man with grey hairs, which, among negroes, indicates an extremely advanced age. His object was to receive the annual presents which the French Director brought with him. These consisted of a great variety of European goods, stuffs, hardware, toys, \&c. partly for the king, partly for his wives; with an additional allowance for the kamalingo, or lieutenant-general, and for the bouquenet himself. The whole value, however, did not exceed seventy or eighty pounds Sterling.

Brue now set out to visit the court. He was attended by six factors, two interpreters, four trumpeters, a few servants, and twelve free no- 
groes, well armed. The country was flat, well cultivated, and full of villages. They came soon to vast meadows, so covered with herds, that it was difficult to effect a passage through them. They then arrived at Buchsar, the residence of the young prince whom they had first seen, and who came out to meet our traveller. Their first salutation was by the one brandishing his zagaye in the attitude of throwing, while the other held his pistol in a similar threatening posture. On coming near, they alighted and embraced. The prince immediately introduced Brue to his wife, who appeared young, handsome, and agreeable. Her features were regular, her eyes lively and well formed, her teeth extremely white, and her olive complexion was improved by the use of a little rouge. Our traveller visited two or three of the other ladies, and then retired to supper, which was composed of the best of African dishes. It was now armounced that all was ready for the folgar, or ball, an amusement to which, in a negro town, every object must yield. All the youth of the village danced and sung, while those more ad. vanced in age sat on mats and conversed. Their conversation shewed a prodigious memory, and their expressions were dignified and correct. A violent shower of rain put an end to the amusement, and drove all within doors.

Brue departed next morning for the residence 
of the Siratik. He was met, at some distance, by the Kamalingo, or general, who escorted him to the palace, situated about half a league from $\mathrm{Gu}$ mel, the principal village. It consisted of a great number of cottages, surrounded by an enclosure of green twigs interwoven, and defended by a thick hedge of thorns against the approach of wild beasts. The French, on being introduced to the Siratik, found him seated on a bed, surrounded by several of his wives and daughters, who sat on mats upon the ground. The prince rose, shook the Director's hand repeatedly, and made him sit down. Brue having then explained his views, the Siratik, in the most liberal manner, and with many expressions of friendship, granted him liberty, not only to establish factories, but to build forts in any part of his dominions. This last article is remarked as indicating a very peculiar degree of favour; for, though the African princes are extremely desirous of commerce with Europeans, they view, with strong and natural jealousy, the formation of military stations. Brue was so much pleased with having obtained this privilege, that he drew forth, in addition to his former presents, several swords mounted with silver, pistols, telescopes, and other curiosities. This new donation being wholly un: expected, called forth an ardent burst of gratitude from the monarch.

Brue was now introduced to the audience of the voL. I,

I. 
queen and princesses. He was graciously received, and offered each a present, which, though of little value, afforded pleasure by its novelty. Being then observed to look attentively at one of the daughters, a young princess of seventeen, she was immediately offered to him in marriage. Brue declined this honour, on the plea that he was already married; but as this -appeared no obstacle in the eyes of an African, he was obliged to add, that the religion of his country allowed of one wife only. This notice gave rise to much speculation on the part of the African ladies. It was agreed, that the lot of an European wife was truly enviable ; but Brue was strictiy interrogated, how far he found it easy to observe fidelity to his consort, during so long an absence. Suspicions were also intimated, that her own constancy, when exposed to such a trial, could be very little depended upon. These remarks, with many other inquiries respecting the manners of France, protracted the interview till a late hour. Brue then retired, and a splendid supper was sent him by the queens, dressed in the African manner; he took a portion of every dish, from respect rather than inclination.

Next morning, the king came in, and spent two or three hours in familiar conversation; after which, they went to a review of the cavalry. On their return, our traveller had an opportunity of observing 
the mode in which justice was here administered. The Siratik was surrounded by ten old men, who examined the parties separately, and made their report to him. No attorney, or advocate, was to be seen; each party pleaded his own cause, and the sentence was always executed without a moment's delay. Few crimes are punished with death, but most by what is here termed banishment, which, when explained, proves to be, the selling him to the French company, and taking possession of his effects. The insolvent debtor is sold with his whole family - the king drawing a third of the price.

The king being now incommoded by the multiplication of the species of fly peculiar to this country, determined to remove to another part of his dominions, where he would escape that annoyance. Our traveller, therefore, took a friendly leave; and before his departure, had an opportunity of observing the order of the royal march. The advanced guard consisted of a hundred and sixty horsemen, with different species of trumpets and timbrels, which made a noise, extremely loud, but destitute of any species of harmony. The queens and princesses next followed, mounted on camels, two on each, and so completely enclosed in large ozier baskets, that no part of them was seen except the head. The female attendants, mounted on asses, rode by the side of their mis- 
tresses, and endeavoured, by constant talk, to keep them amused. All this gay train, as they passed, saluted the Director, and wished him a prosperous voyage. They were followed by a long cavalcade of camels and asses, carrying the baggage ; then by three hundred horsemen, behind whom rode the king, well armed and splendidly attired. Another body of horsemen closed the rear. In these troops, the foremost ranks were composed of the principal lords of the court. They all, in passing, saluted the Director, and were received by him with music and discharges of musquetry. Our traveller then commenced his return to the Senegal. On his way, he paid a second visit to Buckar Sire, and was entertained as before, with a festival and folgar. He afterwards proceeded to Ghiorel, and entertained the prince on board of his vessel. The French found here the opportunity of a somewhat novel species of trade. The women of the neighbourhood, being impressed with the conviction, that the bilge-water, pumped out of European vessels, was a sovereign remedy for the toothache, came eagerly, offering large quantities of milk in exchange for so precious a medicine. The French sailors hesitated not to avail themselves of this persuasion; and having fixed the price of their commodity, measured it out in proportion to the milk offered; and when that appeared insufficient, gravely replaced it in the pump. Mean. 
time, a more respectable trade had been carried on by the two barks which were sent up to the kingdom of Gallam. They did not ascend beyond Layde, or Lady, a town situated on its frontier. Their opportunities of trade had been so abundant, that, on reaching that point, they found their stock of European commodities exhausted. They could not thus proceed farther with any advantage. The Director did not himself attempt to penetrate higher ; but having established a factory at Ghiorel, immediately sailed down to Fort St Louis.

Although, in the voyage which we have now narrated, Brue had not proceeded farther than the states of the Siratik, he had always kept in view the plan of ascending to Gallam, and of ascertaining the highest point to which the Senegal could be navigated. Particular circumstances delayed, during the following year, the execution of this project. In 1698, he again set sail, with a large shallop, and some canoes, laden with merchandize and provisions. Happening to travel by land along part of the shore, he had an opportunity of observing its aspect. It was found intersected by deep valleys, where lions and elephants assembled in great bodies. The elephants were so tame, that they shewed no alarm at the sight of men, and, unless when first attacked; were perfectly harmless. These low grounds are covered with thorns, which rise to a prodigious height, and bear flowers of a beautiful 
yellow. Vast numbers of monkeys were also observed. The negroes, who, on account of the injury which these animals did to the plantations, had never viewed them in any light but that of a nuisance, were much surprised when they found them eagerly sought after, and purchased at high prices by Europeans. Many, on observing this, brought rats, and offered them for sale, expecting that the same taste would attach to them a similar value.

The director proceeded next to Ghiorel, whence he paid a visit to the Siratik, who received him in the same amicable manner as before. The Dutch, it appeared, had sent an embassy, and endeavoured to draw him off from the French alliance, but without success. The monarch implored the assistance of Brue, to deliver him from an enormous lion, which was the terror of the district. The Director, accordingly, sent four of his negroes to attack this formidable animal. The lion was soon found, and the encounter took place. It was terrible; he killed two negroes, and dangerously wounded a third, whom he would have dispatched, had not the fourth, by a happy stroke, killed him on the spot. The carcase was borne in triumph to the palace, and the skin presented to the French governor.

Brue now left Ghiorel, and ascended the river. In passing Embakané, near the frontier of Gallam, a singular spectacle presented itself. The sun was suddenly darkened, and, on looking upwards, they 
discovered the whole sky covered with an army of locusts, who were taking their flight across the river. The passage continued for two hours, in the course of which, the boats were entirely covered with their excrements. Fortunately for the country, a south-west wind blew them towards the desert, where they probably perished for want of food.

The next place which our party reached was Bitel, which they found to abound with poultry beyond any other district in Africa. The chickens here were equal to the best European capons. A fat pullet was readily sold for a sheet of paper. They arrived next at Tuabo, situated on the immediate frontier of Gallam. Its vicinity was distinguished by the abundance of a species of red monkeys, not before observed.' They came in crowds, from the top of the trees to the extremity of the branches, in order to take a view of the boats as they passed. They appeared to come in successive parties, and to converse with each other on what they saw; and some even became so familiar, as to throw down dry branches into the vessels. These advances were very ill received by the French, who answered them with discharges of musquetry, by which several were killed and wounded. This caused an extraordinary tumult; some raised frightful cries, while others collected stones and other instruments of offence, and threw them 
at these unknown invaders of their haunts. The combat had not lasted long, however, till they found that it was an unequal one for them, and prudently retired into the interior of their forests.

The next phenomenon which our party encountered, was a person entitling himself " King of the Bees." He came accordingly to the boat, entire. ly covered with these animals, and followed by thousands, over whom he appeared to exercise the most absolute authority. They followed him " as sheep their shepherd," and were never known to injure either himself, or those whom he took under his protection.

The French, on their arrival at Tuabo, had been informed, that a revolution had taken place in the government of Gallam; that Tonka Mouka, the late king, had been dethroned, and succeeded by a rival, Tonka Bukari. On arriving at Ghiam, two negroes appeared, who confirmed the intelligence, and also intimated, that the new king was in full expectation of receiving the duties paid to his predecessors. Brue stated, that he had no intention of withholding these duties, provided it appeared that Tonka Bukari really was king; but that he wished previously to have an opportunity of ascertaining the fact. A messenger soon after arrived, announcing that Tonka Bukari was in a neighbouring village, and that, unless the duties were instantly paid, he would declare war against the 
French, and prevent them from penetrating higher up the river. The Director conceived himself called upon to maintain his dignity, by setting these threats at defiance. He declared, that he would continue his voyage, whether he received the permission of Tonka Bukari or not; and that, if war was declared, he would land and lay waste the country. The negroes now collected upon the banks in great crowds, and in a threatening position. The Director, however, by sounding his drums and trumpets, and by firing a few rounds of cannon without ball, soon succeeded in dispersing this armament. He then continued his voyage without molestation; but every information which he received confirmed the fact, that Tonka Bukari was actually in possession of the throne; with the addition, that the chiefs who had raised him to it were determined to prevent 'Tonka Mouka from ever reascending it. Our traveller, therefore, who had no disposition to investigate the right, provided he knew where the power resided, determined immediately to pay his respects to Tonka Bukari. He set sail for Burnaghi, the residence of the new monarch, and sent a messenger to say, that he would wait upon him, and pay the accustomed duties. The monarch received this notice in the most gracious manner, and offered to come in person and visit the general. He sent next day a present of cattle and poultry, and the 
day after appeared with a numerous suite. Brue. received him politely, and conducting him into his cabin, presented him with some chocolate. The king drank it with relish, having previously, however, required a solemn assurance, that it contained neicher hog's flesh nor wine. Notwithstanding these scruples, on brandy being presented, he drank it readily, and with the greatest apparent relish.

The same evening Brue returned the king's visit. The palace, or rather hovel, in which this monarch resided, could scarcely be distinguished from those inhabited by the meanest of his subjects. Every thing bore the aspect of the most extreme poverty, over which he in vain attempted to throw a veil. The chiefs, who raised him to the throne, had not, it appears, taken any steps to provide him with a revenue; and he had, as yet, no opportunity of collecting one from the usual sources. The presents made to him were received with the most ardent burst of gratitude; but he did not, according to the invariable custom of Africa, make any in return. This omission, however, did not offend the French, who were satisfied that it arose from no motive but that of having nothing to give.

The wind becoming west, and thus favourable for ascending the river, Brue immediately set out to continue his voyage. He arrived soon at Baba Seghalie, the residence of Tonka Mouka, the deposed king, who had still, it appears, a considerable 
number of followers. The director called upon him, and made some little presents, which were received politely, and with apparent satisfaction. But he soon after sent his son to assure the French governor, that he had been entirely deceived as to his present situation; that, though some of his subjects had revolted, he was still sovereign, and would soon reduce them to subjection; the French, therefore, would do well to pay him the customary duties; otherwise he would not only interrupt their commerce, but would cut off their return. Brue seems to have made an uniform principle of repelling threat by threat; he therefore informed the young prince, that he would pay no duty, would carry on commerce as he chose, and on the least insult, would send his father and himself prisoners to America. This speech induced the prince to a very speedy departure, and the French continued. their voyage till they arrived at Dramanet, a town of considerable magnitude. The inhabitants, 4000 in number, are Mahometans, and the best träders whom the French had yet met with. They carry on trade as far as Tombuctoo, which they described as situated five hundred leagues in the interior. They imported from it gold and ivory, and slaves from Bambarra, which they described as an extensive region between 'Tombuctoo and Kasson, barren, but very populous. They had been chièfly accustomed to send their commodities to exchange 
with the English on the Gambia; but they now eagerly opened a trade with the French, who, by coming to the spot, saved them the labour of carrying them to a distance. Meanwhile, Tonka Mouka, who had deeply resented the contempt with which the French had treated him, appeared in the neighbourhood with a body of troops. The inhabitants, however, assured the French, that they had nothing to fear, and that they would shed the last drop of their blood rather than yield. Tonka Mouka, however, succeeded in entering the city; but a thousand of the adverse party having arrived, he was obliged to retire with precipitation. The ex-king, however, again sent a threatening message, and a demand of his duties; but receiving an answer of defiance, he gave notice, that he would rather retire than come to blows with the French; which intention he accordingly executed. The Director then went up to the rock or cataract of Felu, which, crossing the river in such a manner as not to be passed without extreme danger, had hitherto formed the limit of French navigation. The hills which form it intersect the country in such a manner as to render it almost impassable. Brue, however, left his boats two leagues below, and reached the cataracts by land. He intended to have proseeded to the falls of Govinea, forty leagues higher, but as the Senegal was rapidly falling, he found reason to apprehend, that, by longer delay, it might 
become impossible to pass some obstacles which occurred in his return to Dramanet. He therefore sailed back to that place, and after having made a careful survey of all the neighbouring positions, fixed upon its vicinity for the erection of the fort, which was to be the centre of French commerce in the interior of Africa. He then sailed down the river to Fort Louis.

In the course of this voyage, Brue made very anxious inquiries respecting the countries beyond Gallam, particularly concerning the Niger and Tombuctoo. He was informed, that, on the east and north-east of Gallam, about midway between the cataracts of Felu and Govinea, began the kingdom of Kasson, which was said to be formed into a species of island, or rather peninsula, by branches of the Senegal. The king of Kasson was powerful, and had formerly reigned over all the neighbouring states, who were still his tributaries. Gold was so abundant in Kasson, that the metal often appeared almost on the surface of the ground. From this description, compared with that of Park, it appears that Kasson was in some degree confounded with Bambouk and Manding, which confine with it on the south. Beyond Kasson was another kingdom called Bambarra, to the east of which lay that of Tombuctoo. The Mandingo merchants added, that Tombuctoo was not upon the Niger, but at a considerable distance in the interior. Leaving the Senegal at Kaignu, where it ceased to 
be navigable, they passed by Jaga, Bayogne, Konguru, Sabaa, Baramaga, Goury, and Galama, to Timbi. This journey occupied twenty-seven days. At Timbi, they quitted the river, and after a land journey of five or six days, arrived at Tombuctoo. Here the Niger was evidently quitted with the view of reaching Tombuctoo by a more direct route; and was erroneously supposed to be distant from it by the whole of that route. A lake, called Maberia, (the Dibbie of Park,) was also mentioned, from which the Senegal was generally said to issue. Beyond it lay the kingdom of Ghingala, (Jinbala of Park,) watered by the river Ghien, which passed by Tombuctoo. A large caravan of white men, whom the French justly conjectured to be the Moors of Barbary, with fire arms, arrived every year at Tombuctoo, for the purposes of trade. Large barks, with masts, had been seen near Tombuctoo, which were conjectured, though erroneously, to belong to the Tripoli merchants.

With regard to the course and direction of the $\mathrm{Ni}$ ger, two opposite statements were given. One, according to the prevailing European opinion, represented it as derived from a source that lay far to the eastward. After passing through the lake Maberia, and reäching a place called Barakota, it divided into two branches, one of which formed the Gambia, which was represented as passing through a large lake filled with canes, before it reached Barraconda. 
The other branch was the Senegal, and to it the name of Niger was more peculiarly applied. The Faleme was supposed to be another branch, which, after separating from the Senegal, again rejoined it, and formed the intermediate country into a species of island. Others of the Mandingo merchants made an entirely opposite report. They positively asserted, that the Niger flowed eastzard in passing by Tombuctoo. Of these two opinions, Labat, who wrote the discoveries of Brue, decidedly adopts the former; and the same may be said of almost all the travellers in this part of Africa, till the time of Park. On the other hand, the two great French geographers, Delisle and D'Anville, had, on solid grounds, as it afterwards proved, adopted the second report. In all their maps, with the exception of the earliest ones of Delisle, the Niger is represented as a separate river from either the Gambia or Senegal, and as fiowing eastward by Tombuctoo. Labat expresses himself much at a loss as to the grounds on which they had founded this construction; and nothing certainly can better illusstrate the excellent information possessed by these geographers. On this subject, however, an opportunity will occur of making some farther observations in the part of the work where we shall treat expressly of the Niger.

Brue, after his return to Fort St Louis, made several voyages along the coast, to the mouth of 
the Gambia, and to the Archipelago of Bulama. But he never afterwards revisited Gallam, nor penetrated far into the interior of Africa. He made, however, another voyage up the Senegal, with the view of some arrangements concerning the trade in gum. Although this did not carry him high up. the river, yet it introduced him into a different region, and to scenes and personages entirely different from those whom he had before met with.

The spot where the gum trade is carried on, is on the north bank of the Senegal, almost immediately before it turns to the south, and, splitting into two channels, which form the large island of Bifesche, discharges itself into the Atlantic. The territory on both sides of the river belongs to the kingdom of Hoval, subject to a prince, who assumes the title of the Great Brak, which, in the language of the country, signifies " King of Kings." This mighty potentate had some days before plundered a party of Moors; but was in such mortal dread of their vengeance, that he durst not quit his residence at Engherbel. He therefore entreated Brue to cast anchor immediately before that place, in order that he might have an interview with him without danger to himself. The director agreed to this request, and having announced his arrival by the discharge of cannon, the king appeared with his retinue on the banks of the river. A cordial meeting took place; but Brue, before receiving his ma* 
jesty on board, stipulated, that he should, during the visit, abstain from the use of strong liquors, in consideration of the inconveniences to which they were apt to give rise. The Brak readily closed with this condition, and he shewed every disposition to make favourable arrangements as to the objects which the French had in view. As soon, however, as his majesty arrived on board, he began to crave brandy with such earnestness, that the Director found it impossible to refuse it. To the surprise of all, however, this liquor was used in such moderation, as not at all to disorder the royal judgment; and he behaved throughout in a very reasonable and friendly manner. Every thing demanded by the French was granted unless in one instance, where they were themselves satisfied by the reasons alleged against it. The king then went on shore amid the acclamations of the court and people, who were stationed along the banks.

The same afternoon, our traveller was visited by two ladies, sisters of the Brak. They were handsome, particularly the youngest, and had a lively and graceful air. Their dress consisted chiefly of two large pieces of black cotton with white stripes, one piece wrapped above the other. This upper covering forms a great mark of distinction. In very hot weather it is thrown off, and leaves all the upper part of the body uncovered. Their chief ornaments consisted of coral beads, and gold ornaVOL. I. 
ments in the hair, with gold bracelets and chains on the arms. They took great delight in shewing their hands, particularly the nails, which were long, and dyed red at the extremity. Their teeth were of a brilliant white, produced by the use of a particular species of wood. Brue received them with great politeness, and presented biscuits, prunes, and confections. After conversing for some time in a very sensible and agreeable manner, they began to sing, and made their Guiriot dance. This personage performed her task with remarkable agility, but with a display of gestures so very indecorous, as greatly to scandalize our traveller. The two ladies then took their departure.

Next day, the Brak himself again appeared, with his wife and three daughters, who sat down around him in very grotesque attitudes. While they were sitting, the arrival of Schamchi, chief of the Moors, was announced, to arrange the terms of the approaching market. On discovering the Brak, he declined entering on business in his presence; but no other mark of hostility took place. After the king's departure, a pretty sharp discussion arose respecting the terms on which the trade was to be conducted. Brue obtained some new advantages; yet was obliged also, for the sake of peace, to abate somewhat of his first demands. It had been established, that, while the market lasted, the French should supply the Moors with provisions, of which 
they often experienced a scarcity. This condition produced an immense concourse, both of those who had gum to sell, and of those who had not. Brue insisted that a scrutiny should take place, and that none should be fed, who did not come duly provided with the materials of trade.

About this time, the Brak was thrown into extreme consternation by the intelligence, that Addi, a Moorish prince, was approaching with a body of troops, and, as his conscience suggested, to revenge the wrong sustained by his countrymen. A messenger arrived at midnight at the Director's quarters, to announce this intelligence, and implore his assistance. While Brue was deliberating what course to follow, notice was received, that Addi was coming with the most pacific intention, and merely to pay a friendly visit to the Brak. As he was attended, however, by twenty fusiliers, that puissant monarch requested a reinforcement, in order to secure himself and his capital from any risk of insult. Being supplied, therefore, with fifteen free negroes, he was enabled to muster a guard of thirty musqueteers, who made a respectable figure. When the salute was made by mutual discharges of musquetry, they fired with ball, which was complained of by the Moors as somewhat too rude a welcome. However, the interview passed between Addi and the Brak with the utmost politeness and apparent cordiality. Addi then came on 
board the vessel, and held a long conference with the Director. Unfortunately, the chief topic of his conversation consisted in the most extravagant praises of the Dutch, who were then in possession of Arguin, and whose generosity, and the vast presents they had given, seemed to have made the deepest im. pression on his mind. No subject could be less acceptable to Brue; but though he made considerable attempts to alter the prince's views with regard to that nation, he did not choose to make this predilection a ground of quarrel. Having remained to dinner, the prince at first refused wine; but being prevailed upon to taste Canary, was so much pleased, that he went over, without farther scruple, all the French wines that were in the Director's possession.

On the 10th of April, Brue was honoured with a visit from the principal wife of the Brak, accompanied by the ladies of her court, all mounted upon asses. The general went to meet them, and led them into his apartment, where they immediately seated themselves in the most familiar manner. They had at first three robes of fine cotton folded above each other, but they soon threw off, first, one, and then another, so that their attire was reduced to a single petticoat. They then took out their pipes and began to smoke; when observing that Brue did not follow the example, and learning that he abstained in testimony of respect, the queen insisted on his taking her own pipe, and sent for: 
another. The conversation now became extremely animated, and the Director found it difficult to reply to the numerous questions addressed to him from all quarters. Theladies of France, their beauty, their dress, their gallantry, and the magnificence of the court, formed the favourite topics. While the ladies dined, Brue retired into another room, understanding this to be conformable to the customs of the country. Such reserve, however, appears to have been considered as superfluous; for, in the midst of dinner, the queen sent for him, and made him sit down. When the entertainment was over, he presented them with coffee and chocolate, which they found excellent. At parting he made a number of presents, always the necessary accompaniments of a royal visit, and then saw them on shore. So much pleased does the queen appear to have been with this visit, that scarcely a day elapsed without her sending some present.

On the 17th May, a caravan was seen approaching, which soon exhibited appearances indicating something much superior to a mere company of merchants. After a long cavalcade of camels and horses, with armed men mounted on them, and trumpets blowing, a camel was seen much larger than the rest, and havirig on its back an open seat, on which two females were placed. These proved to be the mother and wife of Addi, who, attracted by the reputation of Brue, came to pay him a visit. 
The Director made every exertion to receive well these fair visitors. Their train was small, consisting only of two or three ladies, and a guiriot. They were both handsome, though the beauty of the eldest was considerably injured by the large. ness of her dimensions. The younger made some use of rouge, without its, however, producing any improvement on her olive complexion. Their chief ornaments were gold ear-rings and necklaces, with grains of amber and coral. They were much more modestly attired than the negro ladies. A large mantle of black Indian cloth covered them from head to foot, and the sleeves were so large, as to envelop even the hands. Brue asked, if they wished dinner to be served up in the European or African style. They left the choice to himself; but upon the dishes of both countries being presented, ate only of the European. The whole interview passed very agreeably, and concluded, as usual, with presents.

The Director closed his residence in this quarter, by paying a visit to the Brak at his own palace. It exhibited nothing peculiar in its architecture, consisting merely of a numerous collection of the same species of habitations which were generally used in the country. The whole was enclosed by a very large hedge of canes, and the entrance guarded by five or six armed negroes. There were buildings within this enclosure for the king 
himself, for each of his wives, his horses, camels, and dogs. The latter seemed an object of peculiar attention and pride; they were eighteen in number, beautiful, and both eyes and scent excellent. The general was received in the same cordial manner as usual, by all the members of the royal family. The king himself, with a numerous train, attended him to the banks of the river.

Brue having concluded his traffic, and made satisfactory arrangements as to the future mode of carrying it on, set sail on his return upon the 1st June 1715. He carried with him 400,000 lbs. of gum, besides slaves, ivory, ostrich feathers, gold, and ambergrise.

From the first establishment of the French upon, the Senegal, Bambouk had been the object of their eager attention and inquiry. It was universally understood, that gold, the most brilliant and valuable commodity which Africa afforded, was chiefly drawn from that country. Yet there were numerous obstacles, not only against entering, but even against gaining any distinct information respecting it. The Mandingo, and other negro merchants, through whose agency the traffic was at present conducted, dreaded being cut off from it, if Europeans should succeed in opening a direct communication. The natives also, conscious that the possession of this coveted metal rendered 
them the envy of the neighbouring states, viewed with jealousy the entrance of foreigners into their territories, and admitted only a certain class of merchants who were known to them, and with whose services they could not dispense. Brue was always sensible, that no success could be hoped in this undertaking, unless an establishment were previously formed in Gallam; and, with that view, he had made the voyage, the particulars of which we have already narrated. Having fixed on the situation above noticed, near Dramanet, he strongly urged the company at home to build a fort here, and make it the centre of their trade with the interior. The slowness and indecision incident to corporate bodies, caused such continued delays, as made him at last give up all hope, when, in 1700 , a vessel arrived from France with instructions, and the requisite means, for forming the establishment. The fort was accordingly built; but, unfortunately, the agent employed, disregarding the position chosen by Brue, erected it on another, which was much too low, so that the first inundation of the Senegal swept it entirely away. The active measures of the Director soon caused it to be erected anew; but immediately after, in 1702, he was recalled to France. This ill-judged step was soon followed by a dissolution of that good understanding which had so long subsisted between the French and the natives. The people 
of Gallam, whom only the address and prudence of Brue could have reconciled to the idea of a French fort being erected in their territory, soon rose in arms to overturn it. Though destitute of all means of making an impression upon European fortifications, yet, by their numbers, perseverance, and by cutting off all supplies, they at length exhausted the garrison, induced them to evacuate the fort, and immediately destroyed it. From this time the affairs of the French, on the Upper Senegal, fell into a state of rapid decline. It was not till 1713, that the Sieur Richebourg, then governor, succeeded in re-establishing the fort of Gallam. It was now built at Mankanet, a little below Dramanet, in a very convenient and advantageous situation. In the following year Brue returned to the government, and applied himself with the utmost vigour to the re-establishment of the Company's affairs. The first object was, to obtain precise information respecting Bambouk; and, with this view, he used every effort to engage one or other of the mercantile factors to undertake a journey thither. Several accordingly set out, with the promise and design of doing so ; but, on approaching the spot, terrified by the reports of the jealousy with which strangers were viewed, and of the perils with which white men were menaced, they shrunk from the trial, and thought themselves justified in retracting their engagement. At 
length one, bolder than the rest, named Compagnon, ventured to pass the dreaded boundary. He was copiously furnished with every commodity which could serve either for presents or trade. He began by insinuating himself into the favour of the Farim of Kagnure, a town situated about fifteen leagues up the Faleme, and in the immediate frontier of Bambouk. This chief sent forward his son with Compagnon to Sambaura. The arrival of Compagnon there caused a mingled sensation of wonder, horror, and dread. Some were for depriving him of life; and the most moderate urged, that no time should be lost in removing him out of the country. His companion, however, pleaded powerfully in his favour; and, when he began to open the stores with which he was provided, a wonderful revolution followed. The Farim undertook his cause, and soon brought over the people to the same disposition. At length he became the favourite of the whole city, and they began to thank heaven for having conducted him thither. $\mathrm{He}$ found no difficulty, therefore, in selecting a few from among the inhabitants to attend and introduce him in other cities. Wherever he went he found always prejudices and opposition to encounter. The people of Silabuli wrote to their neighbours, that they acted like madmen in allowing a white man to enter their territory, and that he ought to be put to death without a moment's de- 
lay. Compagnon, however, by his address, and by the grateful arguments which he was able to employ, generally secured a favourable reception ; and was able, in the course of a year and a half, to traverse the most important districts of Bambouk. His great difficulty was, in procuring specimens of the ghingan, or golden earth, which the region contained so copiously. This was sacred ground; and even those who were otherwise best disposed, considered it almost as treason, that a stranger should touch an object, the pride of their country, and the grand source of its wealth. Our traveller's pretence that he wished to make tobacco pipes of it, was very ill received; as it was reasonably urged, that this was by far too trifling a motive for undertaking so long and dangerous a journey. However, by various contrivances, he at length succeeded in carrying off as much as might serve for a specimen of its quality.

The kingdom of Bambouk is situated on the east of the river Falemé, which separates it from Bondou. On the north it has Gallam, or Kajaaga, and Kasson. Its southern and eastern limits were not well known to the French; but they have been proved by Park to be Jallonkadoo, Gadou, Man. ding, and Fooladoo. It is divided into a great num. ber of districts nearly independent, though they unite for defence against a common enemy. Each is governed internally by its own Farim, who exer- 
cises an authority almost absolute, unless where he is so imprudent as to violate established customs; in which case, an insurrection often arises, and his expulsion is the consequence. Bambouk is chiefly composed of lofty, naked, and barren mountains; so that its wealth consists entirely in its mineral productions. These consist of gold, silver, and iron ; but the gold is so abundant, and so much the most valuable, as to constitute almost the exclusive object of attention. It is found not in 'veins, but mixed with the earth, from which it is separated by the simple process of agitation in water. The mode is particularly described by Park in his last journey. To procure this earth, they do not dig to a greater depth than six, eight, or at most ten feet. They acknowledge, indeed, that it generally becomes richer as they descend lower; but, as they have neither the art of makirg ladders, nor of propping up the sides of the pit, they are in perpetual danger of the earth falling in and burying them. The working of these mines is not free ; it is permitted only at certain seasons by the Farims or chiefs, who attend for the purpose of appropriating a large portion of the produce. The inhabitants believe gold to be a capricious being who takes delight in eluding their search; hence when, after exhausting the golden earth of a certain spot, they come to a portion where none is to be found, they call out, " $\mathrm{He}$ is off." It is always in the driest and most baI- 
ren spots that this metal is found most abundantly.

No steps were taken by the French administration, in consequence of this journey of Compagnon. Such neglect did not proceed from any want of activity on the part of Brue, who submitted to the Company plan after plan.' He first proposed, that the Farims should be conciliated, and permission gradually obtained to erect forts within the country. When this method appeared too tedious to rouse attention, he proposed at once, that the whole should be conquered, and held in subjection; an undertaking for which he judged twelve hundred troops to be sufficient. All these plans and representations failed of making any impression in the quarter to which they were addressed; and Gal. lam continued still to be the farthest limit of French establishment in the interior of Africa.

The governor's of the Senegal, however, never lost sight of Bambouk, the penetrating into which formed, they were sensible, the only means by which their settlement could be raised to the rank of a first-rate colony. In 1739, 1731, and 1732, it was visited by Messrs Levens, Pelays, and Legrand; the former of whom was then governor of Senegal. In 1\%44, M. David, who also held that office, spent a few days in surveying some of its most interesting districts. He had succeeded in making himself beloved by all the chiefs of the 
country, so that, had not the falling of the waters of the Senegal obliged him to lose no time in returning, he could have acquired a thorough knowledge of every part of it. M. Golberry obtained access to his notes, as well as to those of the three other gentlemen before mentioned. He made diligent inquiry also from the natives, as well as from the English traders on the Gambia. From these various sources he compiled an account of Bambouk, by much the most copious and complete that has yet appeared; for Mr Park only travelled along its southern frontier, through part of Konkodoo and Satadoo. It cannot, therefore, be amiss to glean a few additional particulars respecting a country so important in a commercial point of view.

Bambouk is situated between $12^{\circ} 30^{\prime}$, and $14^{\circ} 15^{\prime}$ north lat. It is about thirty-six leagues in extent from north to south, and about twenty-eight of average breadth. The number of inhabitants is not supposed to exceed 60,000. They are of Manding origin, and their natural character, and most of their customs, are similar to those of the other Manding tribes, which have been so fully delineated by Park. They seem, however, to be peculiarly indolent and licentious. The whole country is nominally subject to a Siratik or king; but the Farims or chiefs of the villages, whose situation is also hereditary, exercise a power almost wholly independent. According to the tradition of the 
Bamboukians, in the year 1100 of the Christian era, a Manding warrior, called Abba Manko, inspired with a conquering zeal for the Mahometan religion, invaded Bambouk with a large army. $\mathrm{He}$ conquered it, and compelled all the inhabitants, who had not fallen by the sword, to embrace the profession of Islamism. The next era was the arrival of the Portuguese, which is placed at the commencement of the ninth century of the Hegira. That nation, it is asserted, entirely overran and conquered Bambouk, but giving themselves up to indolence and luxury, were soon so mucb reduced, that the natives rose, and in a single day cut them entirely off. The third grand revolution consisted in the expulsion of all the Marbuts or Mahometan priests. Since that time, the Musulman religion has continued indeed to be professed in Bambouk, but its practice has confined itself to the repeating every day a few sentences from the Koran, and to the ablutions required by that code. In other respects, they have relapsed nearly into their original state of paganism.

The grand object of interest in Bambouk is its gold mines. The principal one is that of Natakon, situated among the mountains of Tabaoura, in the south-eastern part of the kingdom. It is contained in a hill, about 3000 paces in circumference, and not more than 300 feet high. The whole of this eminence is conceived, by Golberry, to be com- 
posed of gold, which occurs in the form of small lumps, grains, and spangles, mechanically united with earth, emery, and grains of iron ore. At the first four feet from the surface, there occurs a fat argillaceous earth, mixed with small particles of iron ore and emery, and from which the gold is extracted by agitation in the form of dust. In digging deeper, the gold is found in larger grains, with lumps of emery and lapis lazuli, which are entirely covered with this precious metal. At the depth of twenty feet, it begins to appear in small lumps, of from two to ten grains. At forty feet, the greatest depth yet reached, still larger pieces are found, sometimes to the amount of fifteen grains; and there is every reason to believe, that, on descending lower, the metal would be found in still greater abundance. All the rivulets, besides, which pass through the plain of Natakon, roll golden sands; and the Colez, called by the Portuguese Rio d'Oro, which descends from the mountains of Tabaoura to the Senegal, bears in its bed a considerable proportion of this precious metal.

About 40 miles to the north of the mine of $\mathrm{Na}$ takon, in descending the course of the Rio d'Oro, is the mine of Semayla. It is connected with the western branch of the same chain of mountains, and is situated in a hillock of a similar aspect, though not so entirely insulated. This hillock is not above 200 feet in height, but it-has a circum- 
ference of nearly 5000 feet. The substances in which the gold is contained are here very different. About two or three feet below the surface is found a species of reddish sandstone, extremely hard; this is mixed with a species of calculous emery, and very hard red marble. These substances cannot be submitted to ablution for the extrication of the gold, without being first pounded, and reduced completely to powder. This constitutes a very tedious and laborious process, especially as the instruments employed are merely a pestle and mortar of hard wood, which are soon worn by the superior hardness of the pounded substances. At the depth of about 30 feet, the miners find a solid stratum of red marble, richly impregnated with gold, but upon which their skill does not enable them to make any impression. For these reasons, the mine of Semayla, though probably richer than that of Natakon, is considered in Bambouk as only of secondary value. The other two repositories are those of Nambia and Kombadyria, both contained in similar hillocks; the gold combined in the same mechanical manner with the other substances. The gold of Nambia, from its peculiar ductility, being easily worked, is more prized by the negroes than any of the rest.

It appears, from the information of $\mathrm{Mr}$ Golberry, that the pits are sunk considerably deeper than had been reported by Compagnon-often as

VOL. I. 
low as 30 or 40 feet. The sides are made perpendicular, without any precaution to prop them up. At first, the soil thus dug is merely thrown into baskets, and handed to the women for washing. As the pit becomes deeper, two ladders of bamboo are employed, one for ascending, and the other for descending. As the miners dig down in this manner, it happens very frequently that they are overwhelmed by sides of the pit falling in. This is an event submitted to by the surviving friends with the most tranquil resignation. They entertain the conviction, that the devil, who supplies the gold found on the surface of their soil, carries on also extensive mining operations of his own under ground, for which he requires a regular supply of workmen from above. As he is understood to treat well the persons thus employed, the transference is not deemed a ground of regret; and the relations merely sacrifice a cow or other victim, to recommend them to favour with their new master. This faith is not in the slightest degree shaken, when, as often happens in the course of digging, the skeletons are discovered of the individuals who have been thus buried. The devil, it is supposed, sometimes errs in his choice of his servants; on finding, therefore, the person fixed upon unfit for his employment, he disdainfully throws him back to the spot where he had been originally found. It never occurs to them, 
that the event could have arisen from a natural cause, or that the sides of the pit could have fallen in, merely because no expedient was employed to support them.

There seems very little doubt, that Bambouk, in the occupation of any European nation, would yield a much larger proportion of gold than is now drawn from it. But it is a much more serious question, whether the produce of its mines could ever repay the expenditure of men and treasure, by which its conquest must be achieved. It might, indeed, in the first instance, be effected by the employment of not a very large body of troops. Besides the general want of discipline, which renders an African army wholly unable to contend in the field with the troops of Europe, the Bamboukians appear to labour under a peculiar want of intrepidity, which renders them often the prey of their hardier neighbours. But after the subjection was completed, the difficulties of the invading army would only begin. The intense heat and malignant character of the climate, the distance from reinforcements, the hostility certainly excited both in the country itself and in all the surrounding regions, would soon render it such a possession, as blind and misjudging avarice alone could covet.

In the year 1749-50, the banks of the Senegal 
were visited by Adanson, the celebrated naturalist. Although he did not penetrate so far up the river as several of his predecessors in the same track, yet the intelligence and activity with which he explored its banks, and the variety of curious information collected by him, render his narrative of considerable value. The first remarkable occurrence was in passing the bar of the Senegal. This bar is a ridge of sand, stretching across its mouth at a little distance under water. The waves rising to a considerable height, and breaking upon the bar, cause considerable difficulty to any vessel that attempts to enter. The care of piloting them through was committed to negro sailors, who turned a deaf ear to all advice or contradiction, and even insisted on a profound silence on the part of the European navigators. To the latter the scene appeared very formidable. One wave lifted them to a great height, and then left them aground till a third came and took them up. The negroes, however, left to themselves, they conveyed our party through without injury, though not without dread. They then found themselves in a very gentle stream, about 300 fathoms: in breadth, and bordered on all sides by an immense plain of white and moving sands. Arrived at Fort St Louis, our author presented his letters to the governor, who received him cordially, and granted full permission to travel through the coun- 
sry in every direction. Adanson, accordingly, set out for the interior, but found his progress opposed by such obstacles, as only his inextinguishable zeal for science could have surmounted. The track by which he went, through the high road of the country, was so neglected and overgrown with vegetation, that it was often impossible to penetrate, unless on all-fours. The underwood consisted frequently of thorns, which, besides their action on the skin, seldom permitted him to pass, without levying heavy contributions on the slight cotton fabrics in which he was clad. At other times, he walked over sands, where the feet sunk to the ancle, and which might justly be called burning, since they were above 60 degrees (of Reaumur) at a time when the ambient air was only 22 in the shade. When the heat was intense, the effects became terrible; the shoes grew first tough like horn, then cracked, and finally mouldered into dust; the feet were thus left defenceless. An obstacle, which appeared at first still more insurmountable, lay in the marigots, or creeks, running into the Senegal, by which the road was frequently crossed. His negro attendant, however, caught him in his arms, and running into the water, though it took him up to the breast, passed it with the same velocity as if he had been engaged in a race. Thus he reached the village of Sor, and found a reception so hospitable, as removed all his preju. 
dices against the African character. He was invited to dinner by the chief of the village, named Baba Sec. They dined without table, table-cloth, spoon, knife, fork, or napkin. A large wooden bowl of kous-kous was placed in the middle, round which the company sat cross-legged on the sand. Each thrust his right hand, by way of spoon, into the kous.kous, and conveyed it to his mouth with the utmost ease and expedition.

The houses of the natives resemble our icehouses. The walls are of reeds fastened together, and supported by stakes driven into the ground. These walls are from five to six feet high, and are covered with a roof of straw, of a circular form, and terminating in a point. The diameter of the whole habitation does not exceed ten or fifteen feet. The door is square, and so low, that, in entering, it becomes necessary to bring the chin and knees into contact. The houses being built without the smallest attention to order, and with trees intermixed, compose such a labyrinth, that a stranger cannot walk through the smallest town without losing himself. The streets, or rather intervals, are entirely composed of that white and soft sand, which forms the general soil of the country. As the natives spend much of their time in the open air, this sand serves at once for table, couch, sofa, and bed.

The negroes, upon the Senegal, are considered 
by Adanson as the handsomest in this part of Africa. They are generally above the middle size, and strangers to any species of deformity, except such as arises from accident. The women are equally handsome, and to those who have become reconciled to their colour, many of them appear almost perfect beauties. Here an English annotator observes, that the numerous progeny, produced between the French and these females, clearly prove this taste not to be peculiar to $\mathrm{M}$. Adanson.

In one of his excursions, our traveller came to a village where no white man had ever before been seen. At his first appearance, the place echoed with the screams of the children, who ran to hide themselves behind their mothers. One of the inhabitants, however, having invited him into the interior of the village, they began first to gaze at him, and, finally, to prefer requests for trinkets and ornaments. The bag in which his hair was tied up, being supposed a repository for tobacco, excited an earnest importunity for a portion of that precious leaf; and he found no relief but in untying it, when no small astonishment and consternation was produced by the view of its real contents. Our traveller here takes occasion to observe, respecting the people of this country, that there is nothing so trifling which they will not ask or take, and that, as thieves and 
beggars, they certainly have no rivals in the universe.

M. Adanson, after returning to the isle of Senegal, made a voyage as far as Podor, a factory situated about sixty leagues up the river. Notwithstanding a few occasional shoals, he found the river easily navigable. Though then at its greatest ebb, it was always at least from twenty to thirty feet deep. The salt water is not felt more than thirty leagues up ; but the influence of the tide reaches as far as $\mathrm{Po}$ dor. The greatest rise which Adanson ever observed the tide to cause at the mouth of the river was two feet and a half; whence he infers, that the descent from Podor to the sea does not exceed that measure ; so that this extensive track of country, with the exception of a few sand hills interspersed, is almost completely a dead level.

At Podor, our traveller remarked a number of beautiful trees, particularly tamarisks, red gum trees, and several other sorts of thorny acacias. The button tree also, from the ease with which it receives the tool, and its fine yellow colour, appeared to him superior for joiners' work to any in the world. He had now an opportunity of particularly observing the ostrich. He saw particularly two tame ones, which, with negro children on their backs, ran round the village with astonishing rapidity. He had the curiosity to cause two full grown negroes to mount the largest one, which set off with 
them, first at only a smart trot; but getting heated, and spreading its wings, soon ran with such swiftness, that it scarcely appeared to touch the ground. The ostrich moves exactly in the manner of the partridge; and, as the latter, with its short legs, outstrips the swiftest runner, it may be inferred what the latter will effect with dimensions so much larger. It is hence suggested what important services might be drawn from the ostrich, could it be trained and managed as a domestic animal.

In the course of this voyage, our author had an opportunity of observing two trees, of a very remarkable character. The first was the mangrove. These are not more than fifty feet high. They grow only in water, or on banks daily inundated by the tide. But the remarkable circumstance is, that their lowest branches throw down roots, which penetrate, and strike into the bed of the river. They form thus a species of natural arcades, and their top a transparent terrace, which might even be walked over, were not the branches too much encumbered with leaves. The other tree is the baobab, which he called calabash, remarkable not for its height, which does not exceed sixty feet, but for its prodigious thickness. In one, which he was shewn in the island of Senegal, he extended his arms thir. teen times as wide as he possibly could, before he embraced its circumference. On measuring it round with a packthread, he found it sixty-five 
feet; which made the diameter nearly twenty-two. From this trunk, several branches extended horizontally, till the extremities touched the ground; and each of these branches being equal to one of our largest trees, the whole calabash composed a species of forest within itself. He afterwards saw a calabash of seventy-four feet, and another of seventy-seven feet in circumference, so that it is undoubtedly by much the largest tree in the world.

About this time the rainy season came on, and our author had an opportunity, for the first time, of viewing its stupendous action in a tropical climate. He was at some distance in the fields when the storm began. The attendant negroes, on perceiving it, instantly threw off their clothes, and plunged into the nearest river ; conceiving it more eligible to be bathed in its.waters, than in those which streamed from above. This plan not according with our traveller's ideas of comfort, he ran under cover of a neighbouring calabash tree. The rain poured down, as if heaven and earth were mingling together; but for some minutes he remained as completely sheltered as if he had been under a house. Soon, however, the leaves being soaked, the openings in the branches became the beds of so many torrents, which discharged themselves upon him, and he was forced to fly for refuge into the open fields. 
The rains having quickly caused the Senegal to overifow its banks, and inundate the adjacent country, Adanson could no longer indulge in his rural excursions. He therefore took voyages to the isle of Goree and the mouth of the Gambia. Returning to the Senegal, he made a second voyage to Podor, and spent also a considerable time in making botanical excursions at the mouth of the river. Although this was going over old ground, yet some new objects occurred, which appear deserving of notice.

Crocodiles were not numerous at the mouth of the river ; but, as he ascended, they occurred often in parties of two or three hundred at a time. They floated often on the surface of the river; above which nothing appeared but the head and part of the back. In this attitude they bear no resemblance to living animals, but to trunks of trees floating on the water. The largest were from 15 to 18 feet long. Our traveller bore a part in an attack which his attendants made upon one of these animals. A negro having espied it asleep at the foot of a tree, stole thither softly, and dexterously struck it in that part of the neck where there are neither bones nor scales, so that it was nearly cut through. The crocodile rising, struck with his tail such a blow as overset his opponent. He instantly rose, however, and wrapped his paan or cloak round the animal's jaw, while another held the tail, and a 
third mounted on the back. A second stroke of the knife then severed the head from the body. The flesh was much relished by the negroes, and did not appear to Adanson so bad as had been reported.

Our author observed, also, a gigantic species of serpent, frequent on the banks of the Senegal. The largest he saw was 22 feet long; but concurring testimonies assured him, that they were often of much greater dimensions, and resembled the mast of an ordinary ship. This creature wreathes his tail into several circles, above which he rears his head and part of his body. In this attitude he looks round for prey; but, fortunately, he is thus very conspicuous, and warns men and even animals to avoid him. He devours chiefly lizards, toads, and locusts, the scourges of the country, and his presence is thus considered as a blessing.

Our author, in one of his rambles, had an opportunity of observing the negroes' mode of tillage. The whole village went out with their lord or chief at their head, and accompanied by all the musical performers whom they were able to assemble. On reaching the field, the music immediately struck up, and the labourers began their task, keeping exact time, and working faster or slower, according to the tune that was played. Their attitudes were such, that no uninformed spectator could 
have doubted, that it was a ball at which they were performing.

In the year 1753, Adanson began to think of returning to France. He made, however, a final journey to Podor, in which nothing remarkable occurred. On his return to the coast he was attacked by a dangerous fever, from which he fortunately recovered, and set sail from the road of Senegal on the 6th September 1753.

In 1783, a Frenchman of the name of Saugnier set out on a commercial adventure to the coast of Africa. He does not appear to have departed in the best humour, having quarrelled with all his relations, and been reduced to a state of extreme indigence. His views were not cheered by the occurrences of the voyage, in the course of which he was shipwrecked on the coast of the Sahara, and detained for several years as a captive. The scenes through which he then passed, will be noticed when we come to treat of that part of Africa. He was ransomed, and returned to France. But pecuniary distress still pressing upon him, he found no resource but in following up his original intention, and embarked for the Senegal. He arrived at the mouth of the river on the 13th June 1785. He passed the bar amid the same peril and terros which Adanson had experienced, and landed on the isle of Senegal. He inveighs bitterly against: 
preceding travellers, who had described this region as almost a paradise, whereas he could discover nothing that was not horrible in the extreme. The country is a plain of burning sand, which affords no delight either to the eye or any other sense. The gardens are few, and produce almost nothing. During the day, the heat to an European is quite insupportable; in the night, it is still painful, and accompanied by the incessant stings of thies without number. The fish is bad, the flesh detestable, and if kept a single day, must be thrown into the river. Water is found only by digging five or six feet deep, and then brackish to a degree, which even distillation will not wholly remove. If a man goes out to take a walk, he is in hourly danger, either of being devoured by wild beasts, or carried captive by men equally ferocious. The only benefit is, where he is tired of life, and seeks a termination to it; since, by merely remaining on the spot where he is, this wish will be certainly and very speedily fulfilled. If unluckily he should desire to prolong the term, this can only be done by adopting the diet of the negroes, which is utterly loathsome to an European palate.

Saugnier agrees with Adanson, in describing the men of Senegal as the tallest and best made, and the women as the handsomest in Africa. The former are also remarkable for courage, to a degree bordering even on rashness. Their chief fault is 
that propensity to rapine, which they have in common with all other negroes. The marabuts earnestly inculcate upon them the duty of stealing whatever they can from Christians; and though careless as to other articles of the Mahometan creed, they cannot be accused of negligence in this one particular. The negroes here are either Christians or Mahometans; or, more properly, both ; or, most properly, neither; a piece of glass or iron being always sufficient to produce, if required, an immediate conversion.

Saugnier, finding the mercantile departments at Senegal in a great measure preoccupied, resolved to undertake in person the voyage to Gallam, which, being a rare and dangerous exploit, would, if successful, raise him to distinction. He set sail, accordingly, on the 16th August 1785, with a vessel of seventy tons, and a crew composed of negroes. He admits that his pursuits and turn of mind led him to pay little attention to objects of natural history; so that the information collected by him is almost entirely commercial. After passing Podor, he had some communication with Admet Moctar, chief of the Moorish tribe of Trasarts. . That prince, it appears, had formed a design of surprising and seizing the vessel; but not being aware that Saugnier understood Arabic, which he had learned in his captivity, he announced his design in that language, while Saug- 
nier was present. The Frenchman hastened to the ship, threw into irons all the Moors on board, among whom was a brother of Admet, and sent for assistance from Podor. Thus the Moorish prince, or robber, (the terms are synonymous,) not only failed in his scheme, but was obliged to make a handsome compensation.

Saugnier, on arriving at Gallam, found every facility in carrying on trade. Slaves, ivory, and gold, were to be had in abundance; and the Saracolets (Serawoolies of Park) are active and intelligent, and every way fitted for this employment. In treating with them, however, as well as with the Moors, it is very expedient to have a room for the purpose entirely emptied of all merchandize; otherwise it runs an imminent risk of suddenly disappearing. While the discussion lasts, their eyes are continually rolling around, in search of something which could be easily appropriated. At the same time, they are extremely jealous of the respect paid to them, and are highly dissatisfied, if, during their visit, the attention be at all distracted by any other object. The trade of Gallam is very profitable, yielding at least cent. per cent. This advantage is balanced by the unhealthiness of the voyage, and the various dangers to which it is exposed. These Saugnier himself amply experienced; as, in sailing downwards, his vessel was wrecked, and the greater part of the cargo plun- 
dered, partly by his own crew, and partly by the chiefs of the neighbouring villages. He bitterly complains of the prohibition by the government of Senegal, against taking any violent steps with regard to those monarchs. Hence, though he had, at one time, eight princes in chains, he was obliged to release them, without deriving any benefit from so commanding a position. In a state of violent chagrin he arrived at the colony, where it appears that he was generally considered as in a state of insanity. This insinuation he strenuously repels, yet admits, that he drove from him all the inhabitants, black or white, conceiving them alike destitute of faith or honesty: Soon after, finding his health impaired, he set sail for France. In the preface to his narrative, he submits a plan for penetrating into the interior of Africa ; first, along the Niger to Tombuctoo, and then across the continent, either to Abyssinia, or to Mozambique. It does not appear that the French government felt any such zeal as could induce them to close with this proposition.

So far as can be judged from his narrative, Saugnier appears to have been a man of enterprise and abilities, but of a violent, rash, and quarrelsome temper, which, by embroiling him with almost all who came into contact with him, finally rendered his schemes abortive.

roI. I. 


\section{CHAPTER III.}

EARLY DISCOVERIES OF THE ENGLISH.

First Voyages to the Senegal and Gambia.-Plans for penetrating to Tombuctoo.-Thompson.-Jobson.-Vermuyden. -Stibbs._Job-Ben-Solomon.-Moore.

$T_{\mathrm{HE}}$ attempts of the English to form establishments on the central rivers of Africa were commenced at an early period. In 1588, Queen Elizabeth granted a patent to certain rich merchants of Exeter, to carry on the trade of the Senegal and Gambia. Accordingly, in 1591, a voyage thither was undertaken by Richard Rainolds and Thomas Dassel, "* who visited successively these two rivers. The Portuguese appear by that time to have been entirely driven from the Senegal, as our navigators heard only of one individual of that nation residing upon its banks. But, on the Gambia, they were established in great numbers, and appeared to view the arrival of the English with very peculiar jealousy. In conjunction with one of their country-

* Hackluyt, III. 2. (London, 1810.) 
men, who had come from England, they formed a conspiracy to seize the vessel, and massacre the crew. It was discovered and thwarted. The conduct of the English, and their mode of trading, afforded the highest satisfaction to the natives, who assured them, "that one bar of iron would be more wel"come than forty Portugals." The French are said at this time to have sent from Dieppe four or five vessels, which touched partly at the Senegal, and partly at the Gambia.

The subsequent trade of the English upon these rivers is not recorded; but about the commencement of the seventeenth century, an unbounded zeal was excited to explore the interior of Western Africa. The object of search was that which, in every age, has tempted human cupidity beyond all others-gold. The writings of Leo and Edrisi were in so far known as to make it be understood that they had reported the interior of the continent to contain abundant stores of this precious metal. It was, moreover, known, from the Barbary merchants, that the Moors, after travelling southwards over a vast expanse of desert, came to the regions of Tombuctoo and Gago, * in which gold was abundant. From

* On the 1st of August 1594, a merchant in Morocco wrote to his friend in London, "That you may not think me " to slumber in this action, wherein you would be truely and 
these premises, it was very fairly inferred, that, by ascending the Gambia, which, as one of the mouths of the Niger, was supposed to lead into the farthest depths of interior Africa, they would arrive at length to this great fountain of wealth. The very distance and mystery in which the prospect was involved, spread, as usual, a captivating splen-

" perfectly resolved, you shall understand, that not ten days "past, here came a Cahaia of the Andoluzes home from "Gago, and another principal Moore, whom the king sent. "thither at first with Alcaide Hamode, and they brought "with them thirty mules laden with gold." On. the 30th August, the same person writes, "There went with Alcaide "Hamode for these parts, seventeen hundred men : who pas" sing over the sands, for want of water, perished one-third "part of them; and at their coming to the city of Tombuc"too, the negroes made some' resistance; but to small pur" pose, for that they had no defence but with their asagaies " and javelings poisoned. So they took it, and proceeded is to the city of Gago, where the negroes were in number in"finite, and meant to stand to the uttermost for their coun" try; but the Moors slew them so fast, that they were fain " to yield, and to pay tribute by the yere. The rent of Tom"buctoo is 60 quintals of gold by the yere; the goodness "whereof you know. The report is, that Mahomet bringeth " with him such an infinite treasure, as I never heard of; it "doth appear, that they have more gold than any other part " of the world beside. The king of Marocco is like to be the "greatest prince in the world for money, if he keepe this "country."-Hackluyt, III. 6,7 . 
dour around it. In 1618, therefore, a Company was formed for the express purpose of penetrating to the country of gold, and to Tombuctoo; for that celebrated city was already known as the centre, round which revolved all the commerce and splendour of interior Africa. In order to carry these views into effect, the Company made choice of George Thompson, a Barbary merchant, who seems to have been eminently qualified for the arduous undertaking. He was dispatched with a vessel, the Catherine, of 120 tons, and with a cargo of the value of L. 185\%. His instructions were, that, as soon as the Gambia should become too shal. low to allow the vessel to proceed, he should leave it in some convenient port, and continue his voyage of discovery upwards in boats. Thompson, following these instructions, left his vessel at Kassan, and proceeded up the river. The undertaking, however, excited the jealousy of the Portuguese and Mulatto inhabitants, who, before this time, possessed nearly the exclusive commerce of the Gambia. Having, in Thompson's absence, procured admittance on board, they rose upon the crew, massacred the whole of them, and seized upon the vessel. Thompson was not intimidated by the intelligence of this terrible disaster. He formed an establishment up the river, and merely sent intelligence to his employers at home of what had befallen him, and of the necessity of farther aid; 
but assured them, that, with eight men, who still remained, he would use his utmost efforts to ascend the Gambia. The Company, without a moment's delay, fitted out a new vessel of 50 tons, with a suitable cargo, The very first accounts received of it, however, were of the most unfavourable nature. It had arrived at a most inauspicious season, without any skill or attention to guard against its effects; and the consequence was, that; in a very short time, nearly the whole crew fell victims to the climate. The letters of Thompson, however, still expressing the same confidence and determination as ever, the Company immediately fitted out a new expedition, on a larger scale. It consisted of two vessels, one of 200 , and another of 50 tons, which were placed under the command of Captain Richard Jobson, who proved himself to be a man of resolution and capacity. He set sail on the 5th October 1620, a period which afforded the promise of his reaching Africa at a favourable period of the year. After touching at the Canaries, he arrived in February at the mouth of the Gambia. The first intelligence which there reached him, was the death of Thompson. A deep mystery hangs over the fate of this first martyr in the cause of African discovery. It appears, that he had pushed up as far as Tenda, much beyond what any Eu. ropean had before reached, His object was to have an interview there with a personage of the name of 
Buckar Sano, the leading mercantile character on the Gambia. Thompson, on arriving, found him absent from Tenda; but he received certain intelligence that this district was frequented by caravans from Barbary, a circumstance which he considered as an important test of success in the object of his mission. It is said that, elated by the progress he had made, and the difficulties surmounted, he not only neglected to conciliate the natives, but treated his own party with intolerable haughtiness. The prevailing report is, that, having quarrelled with some of the latter, a conflict ensued, in which he was killed. Whether the charges against him were well founded, or whether they were not prompted merely by a reluctance to follow him into new adventures, is a question which there were no means of ever resolving.

Jobson was not dismayed by this final catastrophe of all who had preceded him in the same career. He determined to employ the same vigour and zeal of his predecessor, combined with greater prudence, His first exploit was to seize a boat containing the effects of Hector Nunez, who was considered the ringleader in the destruction of the Catherine. This was the only step taken by him to avenge the wrong which his country had sustained. All the Portuguese whom he met, affected to speak with the utmost horror of the conduct of Nunez in 
that transaction; but on these professions he pla. ced very little reliance.

Jobson immediately sailed up the river, and having passed Mansegar and Woolley, arrived at Kas. san. All the Portuguese inhabitants had fled from the place; and our traveller was assured, that they had offered high bribes to the negroes to assist in entrapping and destroying his vessel, as they had done the Catherine. 'The English were here received with civility by the alkade or governor. Kassan is described as populous, " and after their " manner warlike." It is surrounded by a large ditch, and three successive palisades, between the two outermost of which, there is a space for cavalry. Many of the edifices have little towers attached to them, from which darts can be thrown on an assailing army. The king's palace is in the centre of the town, surrounded by the apartments of his women, and by an enclosure, the entrance of which is diligently guarded. He is subject to the sovereign of Barsally. The trade consists chiefly in salt, great quantities of which are sent up the river.

Jobson again set sail, and arrived at Jerakonda (Jonkakonda of Park.) Here he met two of Thompson's men, who gave him flattering hopes of the trade higher up the river, but advised him to lose no time; as it would quickly become too shallow to allow him to navigate. Having reached Oranto, 
where Thompson had established his factory, he was soon visited by the king Summa Tumba, ablind man, subject to the sovereign of Cantore. After mutual compliments, "he made haste to drown his wits " in the aquavita we brought him." The people also came in great numbers, "some to sell, all to " beg." Presents, accompanied with expressions of kindness, were now received from several of the neighbouring chiefs. The accounts which they heard " filled them with golden hopes ;" but they soon found that they had committed a capital error in not bringing a larger provision of salt. This was always the first commodity asked for ; nor was any thing else held in nearly equal estimation. After staying some days at Oranto, Jobson set sail on the 1 st of January 1621 . The country now became more mountainous and barren, and the wild animals multiplied. They discovered, in particular, " a world of sea horses, whose paths, as they came " on shore to feed, were beaten with tracks as large " as London highway." On the 12th, they came to the falls of Barraconda, where ridges of rocks, barring the river, prevent the farther influx of the trade. By winding, however, through narrow passages, they succeeded in making their way across this barrier. At Barraconda, Jobson hired a Mar. bat and two negroes, so that the party were now " six white and four black." From this time the difficulties of the navigation daily multiplied. The 
stream was entirely against them; they could not sail in the night for fear of rocks; nor could they, in the heat of the day, undertake the labour of dragging forward the boat. Their navigation was therefore confined to two or three hours in the morning and evening. The shallows and sandbanks became frequent. On the 14th, they were forced to enter the river naked, "very fearful of " the crocodiles," and drag the boat, " heaving and "shoving" over the sand, till they came into deeper water. On the 21st, passing over a high mountain, they sent a mission to the top, but nothing could be perceived except "deserts replenished " with terrible wild beasts, whose roaring we heard " every night." Whenever a crocodile appeared, of which many were seen thirty feet long, the negroes were seized with the utmost trepidation. They avoided the present party, however, owing, as our author conjectures, to their " noise and mul" titude." On the $22 \mathrm{~d}$, as Jobson was walking along the bank, he saw " sixteen great elephants " hard by him," and who had been concealed till that moment by the high sedge. He discharged his piece, which missed fire ; but the report made them run off full speed to the mountains. Frequently, also, " he might see twenty crocodiles, one " by another; and in the night, specially towards " break of day, they would call one to another, "6 much resembling the sound of a deep well, and 
" might be easily heard a league." To complete their hardships, the supply of animal food began to fail, and their muskets, being in bad condition, could not assist them in procuring" a supply for themselves. On the 26th, to their high satisfaction, they discovered the hill of 'Tenda (Koba Tenda of Park.) A message was immediately sent to the king and to Buckar Sano, the great merchant, requesting that he would come down with a supply of provisions. On the 1st February, Buckar Sano appeared. He brought with him his wife and daughter, and a troop of forty attendants. He was immediately regaled with brandy, always known to be the most acceptable treat to an African; and in which he indulged so immoderately, that he lay the whole night dead drunk on board of the boat. This excess, however, seems to have been occasioned by his inexperience; for he ever after guarded against a similar irregularity. On recovering his senses, he proved to be a very cour teqous and reasonable person. He supplied them with abundance of meat and poultry, on very moderate terms. A traffic in their respective commodities immediately began. Salt proved here, as elsewhere, to be the only European article that was in considerable demand; while, among their own, the highest value was placed upon slaves. The grand object of Jobson's search and inquiry was gold; yet he affected to shew indifference up- 
on the subject, and at first did not even name it. A small quantity, however, being produced, some peculiar emotion was doubtless visible ; for the African immediately began to give pompous descriptions of the abundance in which it was produced, and of the countries from which it was conveyed. He assured Jcbson, that he himself had been in a city, the roofs of which were covered with gold. The captain eagerly inquiring the position of this African Eldorado, was informed, that it was situated far to the south, at the distance of four moons (months' journey.) The reported length of the journey at first startled Jobson; but, on considering the slow rate of travelling in this part of Africa, he began to calculate, that the golden city might be placed at no inaccessible distance.

- Meantime, the report of the arrival of white men with European commodities, was spread throughout the country; and vast multitudes flocked from every quarter, impelled partly by curiosity, and partly by the ciesire of trading. They quickly erected for themselves hovels with the branches of trees; so that this spot, which had before been a complete desert, had now the appearance of a little city. At the same time, there appeared on the opposite bank five hundred men and women, almost savages, clothed only with skins of beasts girt round them, "the tails hanging as from the beasts." The women, having never seen a white man, at first 
ran away and hid themselves ; but, on obtaining a glance at some strings of beads, they became soon more accessible. These, like the others, were " all " for salt ;" but, unfortunately, Jobson's slender stock was now exhausted. On both sides of the river, the commodities offered in exchange were gold, ivory, and hides; the latter of which, however, was too bulky to be taken on board the boat.

Meantime, the English experienced every degree of cordiality and attention from Buckar Sano, whose zeal was doubtless rendered more fervent by his being the agent in all their trade, and enjoying a per centage on every transaction. On the Sth of February, he invited them to the king's residence, in order to be present at a ceremony of peculiar import. They found his majesty in the open air, with a fire of reeds, and his grandees seated round him on mats. Buckar Sano then stripped himself naked, and lay down at full length upon the ground; whereupon " divers Marybucks" collected earth, and covered him entirely over. Buckar took up a quantity of the earth, and threw it into Jobson's lap : after which he rose, and stepping a little aside, dressed himself in his best clothes. Then he and his attendants successively having taken up a bow and arrow, after making an appearance of shooting, came and laid them down before our traveller. The purport of all this ceremony was explained to be, that the king had made an entire cession to 
Jobson of Tenda, and all the territory around it. The understcod price was a few bottles of his best brandy; which Jobson paid, not without some reluctance, being much apprehensive that his new dominions would never yield him an equivalent even for the small purchase money.

About this time their stay was inclined by the arrival of the king of Jelicot (Jallacotta), with his " juddies and fiddlers." These juddies our author compares to the Irish rhymers. During the whole time of meat, they recite songs in praise of the king or his ancestors. After death they are not interred in the usual manner, but "put in a " hollow tree upright." Here he heard of two places in the neighbourhood, Tomba-konda (Tambacunda of Park), and Jaye. Of these, he immediately concluded the one to be Tombuctoo, and the other Gago, a country described by Leo as abounding with gold. Tombuctoo, at that era, was always considered to be nearer to the coast than it really was. Hence every traveller, who had made any progress up the river, daily expected that the next city he came to would be Tombuctoo. Jobson, however, did not visit it; and, for reasons not fully explained, did not push his discoveries farther. He does not even express any regret upon that subject, though he alludes at one place to a bar of sand stretching across the river, as forming the chief obstacle. But he; perhaps, 
conceived that, having reached the vicinity of Tombuctoo, and the country of gold, and having discovered traces of the Arabs, or Barbary Moors, who, he was informed, visited this district, he had accomplished the main purposes of his mission, and that little could be gained by ascending farther.

Jobson, being now favoured by the stream, returned to Barraconda in six days, whereas it had cost him twelve to ascend. In passing a place called Batto, he had an opportunity of witnessing the ceremony of circumcision, performed on all the youths who had reached the age of sixteen. It. was totally unconnected with any religious ceremony, and was performed in a very rough manner. No remedy was employed for curing the wound, and the offered aid of the English for this purpose was positively rejected; but the young people were allowed to roam about for two months at perfect liberty, and to steal poultry, and even occasionally a cow, in order to regale themselves. The ceremony itself was the occasion of a splendid festival, to which the neighbourhood had flocked from the distance of twenty miles. Fires were kindled under every large tree, and the solemnity was announced from a distance to the travellers, by the noise of "shouts, " drums, and country music. The roaring, shout" ing, and dancing, continued all night." A pro. minent part on such occasions was always acted by a being called Horey, which our author interprets 
" the devil." His presence is announced by a loud roaring noise, issuing from the heart of the woods, or from rocky cavities. This continues until a large store of the contents of the feast is laid down near the spot, the whole of which, on the departure of the donors, very rapidly disappears. Should this propitiatory gift be withheld, or should its amount appear unsatisfactory, the offended deity seeks redress by seizing on a young boy, whom he is reported to keep lodged in his stomach, until a more copious supply of " belly timber" appeases his resentment. Jobson saw several who had been thus rescued from the jaws of the fiend. They bore on their countenance every mark of the deepest consternation; but maintained an immoveable silence, nor could our author, even by presenting his musket, induce them to answer a single question. He himself conjectures, very shrewdly; that the whole is a mere illusion of their priests, and adds, "the hoarseness of some shew" ed that they had lost their throats in that roar" ing." He had, soon after, a still more convincing proof of the soundness of this opinion. Passing by, in company with a Marabout, they heard, from a little distance, tremendous cries uttered by the Horey. Jobson, not so dismayed, but having a loaded musket in his hand, instantly expressed his determination of discharging its contents at his infernal majesty. The Marabout employed every 
motive of fear or entreaty to divert him from such a purpose ; but seeing that it remained firm, he conreyed a warning to the threatened quarter, in terms sufficiently understood by Jobson, who, hastening to the spot, found a stout negro lying flat on the ground, in a state of such deadly panic, that he was unable even to beg for mercy. After such an exposure, it is truly wonderful to discover our traveller still lending some faith to this superstition; but he considers these persons as merely " belying the devil," who gave, on other occasions, manifest proofs of his power. Thus, on arriving at a place called Pompetane, he found himself expected, and a dinner provided, although he not only had sent no message, but had not even determined upon the journey till the moment of setting out. On inquiring how his host had been so well informed, he was immediately told, that Horey, or the devil, had conveyed the intelligence; to which he lent implicit faith; never reflecting how easily a swift-footed negro might out-run his party and announce their arrival.

Our author now went down to meet the Tenda merchants at Setico, a town about four miles from the river, and the largest he had seen in this country. It formed the highest point to which the Portuguese had carried up their trade, and its population was chiefly composed of Marybucks (Mahometans). A considerable commerce is carried

YOL. I. 
on in slaves, salt, and gold. Here, a principal Marabout dying, they had an opportunity of witnessing the ceremonies performed at his funeral. "He was laid in a house, where a grave was dig" ged, and a great pot of water set in the room; " and, after the Irish manner, much crying (ra" ther than mourning) being made, he was laid in" to the ground; the women running about in a " lunatic fashion with their arms spread, made a " terrible spectacle of sorrow. Neere the grave, " the people sitting down in a ring, a Marybuck " came forth in the midst, who, betwixt saying " and singing, seemed to rehearse certain verses " in praise of the deceased, the people interjecting " their applauses, and running in to gratify their "Vates (prophet or poet) with a present. Thus, " one after another, every Marybuck had his " speech. Singing, howling, and crying, is. used " many days about the grave. They lay all sweet "smells they can get into the ground with him, " and took it kindly that I bestowed some." Much gold is buried with them for their use in another world. The Mahometans here seem to adhere, most religiously, to that precept of their religion, which prohibits the use of sirong liquors. One of them was nearly drowned in a whirlpool, and taken out in a state apparently of total insensibility; yet, on brandy being applied as a restorative, he shut his mouth fast against its entrance. 
On recovering, he eagerly inquired whether he had swallowed any portion of this detested liquor; declaring that he would rather have died than the least drop should have entered his lips.

On reaching Kassan, Jobson found that the climate had done its usual work. The master and great part of the crew of the vessel had died; and there remained not above four in a state fit for labour. He immediately sailed down the river, and returned to Europe; nor does he appear to have again visited the African continent.

It may now be proper to collect a few notices which Jobson has given concerning the country and its inhabitants.

Agriculture is the employment generally practised by all ranks, from the highest to the lowest. Its operations, according to the general practice throughout Africa, are performed entirely with the hand; "God not having given them wisdom " to serve themselves of the beasts for that pur. " pose." The only grain which Jobson had ever seen before was rice; " the resi were rather seeds " than grains." They do not make bread, but boil the grain and roll it up in balls. The fruits are bananas, lemons, and oranges; the palm tree is also noticed. Kolla nuts, repeatedly. mentioned by Park, are described by Jobson. He says, they are much like our larger sort of chesnuts; the taste very bitter, "but causing that which is taken 
" immediately after to be very sweet, water tasting " like white wine or sugar. Fifty of these would "buy a wife."

Among wild animals, he mentions the lion, ounce, civet-cat, and porcupine. Of these the ounce appears to be the fiercest. Elephants were considered formidable by the natives; but, from the Europeans, they fled "as fearefull as a forest stagge." Those who had killed elephants preserved their tails as monuments of their prowess. Wild bulls, wild boars, and antelopes, are also mentioned; and he adds to the list, " beasts unknown." The monkeys and baboons were exceedingly numerous. The latter go in herds of three or four thousand, under the conduct of the largest; one part of whom march in front, another bringing up the rear. "Thus " doe they march on, and are verry bold: and at " night take up their stands on the mountain tops, " or trees above us, where we might heare their "government. For often, in the night, you shall " hear many voices together, when instantly one "great voice exalts itself, and that noyse is all " husht." They are said to form, in the desert, arbours for their " dancing and disport," such that it would be impossible, in seeing them, to doubt having been made by the hands of men. In the forests, our author saw great variety of trees, but none that he could call " by an English " name." 
The manufactures of the country are chiefly three. The smith is by far the principal tradesman, working with very simple instruments, but with considerable skill. $\mathrm{He}$ is a person of great importance, as he supplies at once arms and the implements of husbandry. Every smith, our author asserts, if not carefully watched, will steal. Next comes the manufacture of grisgris, called here gregories, a species of charm which the natives wear in vast profusion. With this is combined the making of bridles and saddles. Lastly, mats are an article in universal demand. "Mats " to eate, sit, and sleepe on, are their staple " commodities; at the markets we saw things bought " and sold, without nominating any price but " mats."

The inhabitants of this region are the Mandingos, Portuguese, Mulattoes, and the Foulahs, called by our author the Fulbies, whom he represents somewhat oddly, as " a tawny people, much " like to those vagrants among us called Egyp"tians." He describes them as addicted to vasturage, and chiefly wandering; during the wetseason, driving their herds to the top of the mountains, and when it becomes dry, bringing them close to the side of the rivers. They live in constant dread of wild beasts; in the night time drive their herds into an enclosure, and surround it with fires, holding themselves always " ready against 
"the roaring assailants." Their drudgery is represented to be very severe; and they were frequently seen entirely covered with flies, which, with a stupidity for which our author bitterly taunts them, they did not even make any attempt to shake off.

The Mandingos, the native inhabitants of this district, are described as living a most idle life, unless during the two months which form their seedtime and harvest. The women live in great subjection; they dress the food, and set it down on the mat before their husbands; but not even the most favourite one, called here the hand-wife, is ever allowed to eat along with him. She dines in another house, each wife having one to herself. In the morning they approach him kneeling. There is no limitation as to the number of wives; all " may have if they are able to buy ;" but besides the price paid to the parents, the king expects a certain gratification. At the ceremony, there is always a shew of violence-the bride being attacked by one party, and stoutly defended by another-the former, however, never fail to prevail in the end.

The trade of this country is described to be entirely in the hands of the Marabouts. Their chief traffic is bringing salt from the coast, which they exchange in the interior for gold, slaves, and kolla nuts. The goods are conveyed upon asses, of 
which they have great numbers; Buckar Sano is said to have maintained 300 . It is very remarkable, that our traveller received a report of the exchange of salt for gold, without the parties seeing each other, exactly in the manner described to Cadamosto; not omitting even the hanging down and putrefying lips, for which salt was the only remedy.

The next narrative of a voyage into the interior of Africa, is one which appears in a somewhat questionable shape. It is contained in a memoir, inserted at the end of Moore's volume of Travels. It is there said to be written by a merchant, who, in King Charles II.'s time, had acquired great wealth by his trade on the Gambia, but who carefully concealed his name, from the dread, that he might be sent out by government upon another expedition. Captain Stibbs, in his journal, however, alludes to the author under the name of Vermuyden, and appears evidently to have possessed a more copious narrative than the one which has reached us, since he mentions several names of places not there to be found. The author begins, by enumerating the articles with which a boat, engaged in such an expedition, ought to be laden. He recommends a hundred pounds of mercury, instead of twenty, which he himself had taken; also a large provision of lead, borax, and sand, 
with several wedges. To this he added three barrels of beef, ten gammons of bacon, salt, both for use and trade; biscuit, rice, gunpowder, strong waters, " and a deal of such like stuff." These supplies, however, though they conduced greatly to the bodily comfort of the expedition, were found to have laden the boat to such a degree, as proved a serious obstacle, when they came to ascend the flats.

Having thus amply provided himself, our author begins abruptly by describing the situation of the principal mine. 'You come first, he says, to a broad collection of waters, not much inferior to Winander Meer, in Lancashire. There, after beating about for a week, and trying many creeks and infalls, he at length fixed upon the channeI coming from the E. S. E. "Up the buffing stream, " with sad labour they wrought," and found nothing to reward their toil till they came to the first fall. Here 47 grains of gold were drawn from 10 pounds of sand. On passing the upper fall, an operation attended with much difficulty, matters assumed a still more flattering aspect. Not only did the sand, when washed, yield gold in abundance; but, on reaching the top of a rock, they discovered, at a little distance, " the very " mouth of the mine itself ;" and he is convinced, that those who are provided with proper instruments, could not desire a richer vein. It is im- 
possible, however, to form the least conjecture where this source of wealth is situated. He apologizes for his " miserable ignorance of the mathe" matics," which made him unable to give any indications of latitude or longitude; but he does not, give the least idea how high it is situated up the river, nor of its relative position to any one place situated on its banks.

The writer, however, now begins something like a regular joumal of his voyage. On the 4th December (the year nowhere mentioned), he began to ascend the river. On the $7 \mathrm{th}$, he arrived at Setico. He kept the middle of the river, as most secure from annoyance; but the sea-horses and crocodiles, "ill pleased, or unacquainted with any co" partners in these watery regions," gave him considerable disturbance. On the $23 \mathrm{~d}$, he appears to be above Barraconda. January 14th, he begins to extract gold from the sand; by washing he obtains 30 grains out of 10 pounds weight ; by mercury 4.7 grains out of five pounds. January $9 \%$ th, he ascended a craggy rock, and began to dig with a pick-axe at a piece of ore, which appeared to afford great promise of wealth. Here he was assaulted by an incredible number of baboons, who would " listen to no oratory but guns," and who, he verily believes, but for the use of that species of eloquence, would have torn them to pieces. Its copious application drove off the assailants, and 
he carried off his ore in triumph; but was much mortified, on reaching the boat, to find that it consisted merely of spar. February 6 th, more golden sand. 15th, a river-horse beat through the boat with one of his teeth, which suggested the contrivance of hanging a lantern at the stern; as these animals kept always at some distance from light shining in the water. February 24th, he made trial of his virga divina, or divining rod, but without the smallest effect. On this occasion he was much ridiculed by his companions, and seems half ashamed of his trust in that potent rod; yet alleges, in its favour, that it might have been dried up during its long voyage from England, and thereby have lost its virtue. March 31st, the ascent began to be very laborious, and they were often forced to strip themselves and drag the boats over the flats. April 7th, perceived the influx of a small river from the south, and came near a fall, which appeared so formidable, as to deter them from all farther progress by water. They landed, however, and after travelling some time, came to a spot, which is described in pompous, though vague terms: "The exceed of gold (says " he) was such, that I was surprised with joy and " admiration." Whether this was the mine described at the beginning of the narrative, does not very precisely appear. Here, however, the author is struck with the deepest admiration at the mag- 
nitude of his own achievement; for he believes, " never any boat, nor any Christian," had ascended so high. He did not, therefore, feel himself called upon to proceed farther, but immediately began his voyage downwards.

Considering the nature of this journal, and the shape in which it appears, shrewd suspicions have been entertained, whether the author ever performed the voyage which he so lamely describes. It is remarked, that gold had never been discovered in this track by any one but himself; that many of his notices have much the air of being borrowed from Jobson; and that nothing can be less precise and satisfactory than the whole tenor of his narration. It is, in fact, so loose and general, as scarcely to afford ground to decide either for or against it. No one else, indeed, has discovered gold; but no one appears to have searched for it so diligently, or to have analyzed the sands, either by chemical or mechanical processes. The mortifying mistakes, and disappointments of his own, which he recounts, bear a considerable semblance of truth. Stibbs, who seems to have possessed a more copious journal, and who was the best judge on the subject, does not express any doubts of his authenticity. If he really ascended the river, he probably went higher than any European. From the time of his passing Barraconda, three months are said to have elapsed; a period which, if em- 
pioyed with any degree of that diligence, of which he boasts so much, must have carried him much beyond the limit of Jobson, who spent only twelve days in sailing upwards from that previous boundary of European knowledge.

From the voyages now narrated, a long period elapsed, without any farther effort to penetrate, by this channel, into the heart of Africa. About the year 1723, however, the spirit of discovery revived. The Duke of Chandos, then Director of the Royal African Company, finding that, as usual in such establishments, the profits fell considerably short of the expenditure, conceived the hope of retrieving its affairs, by the discovery of new and lucrative branches of commerce. With this view, Captain Bartholomew Stibbs was dispatched, with orders to navigate the Gambia as high as possible, and to investigate, if gold was really to be found there in such abundance as had been often reported. Stibbs arrived at James Fort on the 7 th October 1723; he found that Mr Glynn, whom he expected to find governor, had been dead for six months, and was succeeded by another of the name of Willy. To him our traveller immediately wrote, requesting that he would use all possible diligence in hiring canoes suited to the navigation of the river. Mr Willy replied very coolly, that there were no canoes to be had; and Stibbs 
was in despair, on learning that he was giving himself no concern about the affair, and, instead of exerting himself to hire canoes, was even rejecting those that offered. He wrote, therefore, an urgent and somewhat indignant letter, which, he hoped, "would rouse him from his lethargy, and give him " more generous notions of the expedition." $\mathrm{He}$ was much surprised when, three days after, the Company's pinnace brought down the dead body of $\mathrm{Mr}$ Willy. The climate appears to have brought upon him a mental disorder, which terminated in death. Nearly a month, however, had thus been lost, and several of his best officers had fallen victims to the climate. The new governor, $\mathrm{Mr}$ Orfeur, exerted himself very actively to forward the objects of the expedition. It was the 11 th of December, however; before five canoes were hired, and a meeting of council, held on that day, fixed the departure of the expedition for the 26th. Stibbs now found the general opinion of those best acquainted with the country to be, that he ought to have set out at least a month sooner. Although the greatest care had been taken to conceal the object in view, yet he found, as usual in such cases, that it was universally known, and he himself pointed at as the person who had gone to bring down the gold. He had with him fifteen Europeans, thirty Africans, besides several women and boys. There were besides a linguister, or inter- 
preter, who being a Christian, considered himself a white man, "though as black as coal ;" and a balafeu, or African musician, "to cheer up the " men, and recreate them of an evening." Near Jillifree, they discovered a swarm of locusts, which, after having devoured all the herbage in the neighbourhood of that town, took their flight up the river. "They spread at least four miles, darken. " ing the air as they fly, so that neither the sky " nor the air is perceptible through them."

Nothing very remarkable occurred in the passage up to Barraconda. Near'Joar they observed a ridge of hills of a red colour, stretching towards the eastward. The current was not more rapid than is usual in English rivers, and, being assisted by the tide, they ascended with little difficulty. The natives everywhere shewed the utmost readiness to trade; at one place, there appeared on the coast three sticks erected crossways, which they found, on inquiry, to be a saphie, or charm, to draw white men on shore. As they approached Barraconda, similar rumours began to arise respecting the country beyond, They were assured that it was destitute of all supplies, and possessed by a cruel and treacherous race. Stibbs, however, had reason to believe, that these rumours were excited partly by the anxiety of the natives to monopolize all the commodities which he brought with him, and partly by the reluctance of his own attendants 
to proceed farther. He learned on better authovity, that the town of Barraconda had been broke, that is, entirely destroyed, and its inhabitants carried off by a hostile chieftain. Accordingly, on arriving there, they scarcely found ruins sufficient to indicate the scite on which this trading town, once so famous, had stood. A spacious plain here extended four miles from the river, being the most extensive track of level land he had yet seen on the Gambia. Next day, the negroes in a body announced their determination to proceed no farther. They represented, that no one had ever ascended above Barraconda; that Barraconda was the end of the world; or, if there existed any thing beyond, it was merely a country of savages, with whom their lives would be every moment in danger. All the arguments and entreaties of our navigator proved ineffectual, till the irresistible powers of a bottle of brandy were called to their aid; after which, they at length agreed to go as far as the Europeans wént, and no farther.

Stibbs now proceeded to pass the falls of Barraconda. They consist of two solid beds of rock, extending from the opposite sides of the river, and each occupying about a third of its breadth. The space between was choaked up with large single rocks lying so close to each other, as in general to render a passage impossible. Our party found only one, close to the great bed on the north side, and 
so narrow, that, in crossing, both sides of the canoe rubbed against the rocks. On passing this obstacle, it soon appeared, not only that the world extended beyond Barraconda, but that all the evils predicted from the hostility of the natives were wholly chimerical. They were found a harmless people, and supplied them plentifully with fowls and other provisions. They now, however, found themselves in the region of crocodiles, river-horses, and baboons. What was worse, they commenced that struggie against the flats, which continued without intermission during their subsequent voyage. The whole of the narrative henceforth relates to the efforts and schemes for conveying themselves over these barriers. On the 21st, fifteen days after passing Barraconda, they came to a place where there was not water sufficient to float the boats, and the bed being quicksand, which sunk beneath the foot, it was impossible to hawl them through. All the natives assured them, that it was vain to think of ascending higher till the next rains. Stibbs, however, continued to beat about all day and the next night, in hopes of finding a passage; but being still unsuccessful, he gave up the undertaking as hopeless. The river was here diffused to the breadth of 160 yards, doubtless one cause of its extreme shallowness. He was now nearly opposite to Tenda, probably about the same spot which arrested the progress of Jobson. Some merchants 
had offered to conduct him to that place, provided he would purchase ten slaves from them; but his money (which term he oddly employs to signify trading goods) was so bad, that the bargain could not be concluded; and he did not make any attempt to penetrate inland. He immediately proceeded down the river with all possible expedition.

It is probable that other attempts were made about this time to reach the interior of Africa by this channel; but they seem all to have stopped short very nearly at the same point. In 1732, we have an account of a $\mathrm{Mr}$ Harrison sailing up; but he did not proceed beyond Fatatenda, where, finding the sloop could not sail higher, he sent one Leach with boats to the upper parts of the river. Leach sailed twenty-two leagues above Fatatenda, where he encountered a ledge of rocks stretch. ing across the river, that appeared to present an insurmountable barrier to his farther ascent. This ledge is not mentioned by any of the prior navigators, who describe their course as arrested merely by shallows and sand-banks. This circumstance makes it possible that he may have ascended somewhat higher than the rest; though the space passed over precludes the idea of the length of his course having materially differed from theirs.

About this time some intelligence was gained respecting the interior of Africa, by a very remark.

vol. I.

Q. 
able channel. It was from a young prince, son of the king, or chief of Bunda, in the territory of Foota, who was accidentally made captive, and carried into America. He is called by Moore the high priest of Bunda; and appears, in fact, as is not unusual in Mahometan countries, to have united the characters of pontiff and monarch. He was sent by his father to carry on some traffic on the Gambia, with strict injunctions not to pass that river, as the inhabitants of the opposite bank were Mandingos, and deadly enemies of Foota. The young prince, however, in whom curiosity and the desire of knowledge were powerful propensities, felt an irresistible desire to pass this limit. Dismissing his domestics, he entered into engagements with a negro merchant, with whom he crossed the Gambia. One day, feeling the necessity of repose during the heat, he hung his arms on a tree, and lay down. At this moment a party of Mandingos arrived, and seized upon the young chieftain. He was brought to Joar, and sold to a Captain Pyke, who was taking in slaves for America. The captain, on hearing the quality of his captive, readily allowed him to send a message to his father, and afford an opportunity of ransom; but the distance was so great, that, before an answer could arrive, it was necessary to set sail. Soon after a deputation arrived with an. immense ran- 
som; but it was too late,-the vessel had departed.

Job was carried to Maryland, where he was employed first in the cultivation of tobacco, and afterwards in the tending of herds. He does not appear to have been positively ill-treated ; but the recollection of his former greatness continually embittered the sense of his present condition. Above all, his strict observance of the rights of the Mahometan religion exposed him to perpetual ridicule, and even insult, from the white inhabitants. His life became thus intolerable; and he resolved, at all hazards, to attempt an escape. He fled across the woods to the county of Kent, in the bay of Delaware; but, being unprovided with a passport, was there arrested by virtue of the act against fugitive negroes. The case, however, attracted a good deal of curiosity; and he was visited in prison by several English merchants ; particularly one of the name of Bluet, who afterwards wrote the history of his life. They soon discovered that he was a Mahometan; but they remained in the dark as to other particulars, till an old Jaloff, who understood the language, met him, and explained the whole of his history. These particulars being transmitted by letter to London, became a general theme of conversation, and $\mathrm{Mr}$ Oglethorpe, who held a high place in the African Company, was deeply affected by the situation of the royal cap. 
tive. He sent instructions to ransom, and bring him to England, with the view of restoring him to his native country. Job arrived in April 1733, at a time when Oglethorpe had set out for Greorgia; but his friend $\mathrm{Mr}$ Hunt received him into his house. He became now an object of general interest, and received many marks of attention from the most distinguished personages in this country. He was introduced to the king, queen, and the rest of the royal family, and received from her majesty the present of a handsome gold watch. The Duke of Montagu invited him frequently to his house, where he was introduced to the principal nobility. He learned to speak and write English, and was even able to assist Sir Hans Sloane in the translation of Arabic manuscripts. His memory is said to have been very extraordinary. He wrote out three copies of the Koran, merely from recollection, and without using the first in making out the two others. He had a peculiar turn for mechanism. Though a zealous Mahometan, he talked in a very temperate and rational manner on the subject of religion. He considered his captivity as fortunate, from its enabling him to acquire various branches of knowledge, of which he must otherwise have remained ignorant.

Job set sail from England in July 1734, and arrived at Fort James on the 8th of August. Notwithstanding the gentleness of his disposition, 
which is much extolled, he shewed a very furious antipathy to all individuals belonging to the nation who had reduced him to slavery; and he was even with difficulty prevented from attacking and killing them. He testified extraordinary exultation at learning that the king who had thrown him into slavery was afterwards killed, in consequence of the pistol which he wore accidentally going off; and he flattered himself that this pistol might be one which had been received as part of the price of his captivity. A messenger was immediately sent to Job's father, informing him of his son's arrival, and requesting an escort to conduct him home. He waited impatiently four months the return of this courier. When the news at last came, they were rather of a gloomy description. The father had died almost immediately after learning, the return of his son; and the country was then in a very distracted state, in consequence of a long war in which it had been involved.

Job was deeply afflicted by this information, but determined immediately to set out for Bunda. As he was departing, however, Moore, to whom we are indebted for these last particulars, left Africa, and no farther tidings, so far as we can learn, ever reached Europe respecting this young African prince.

There seems little doubt, that the Bunda, described as t'e native country of Job, must have 
been the Bondou of Park, situated on the Upper Senegal, immediately to the east of Foota Torra. Job reported, indeed, that Tombuctoo lay on the opposite side of the river; a statement, the correctness of which is placed totally out of the question by the smallness of the interval intervening between it and the Gambia. Tombuctoo is apparently the European interpretation of some other city mentioned by Job, most probably Tamboucanee, noticed by Saugnier, as a mart for slaves and produce, about sixteen leagues above Gallam. Among the particulars obtained from Job respecting the manners of the country, the following are the most worthy of notice. The people of Bunda are strict Mahometans, and the persons of distinction pique themselves on being well instructed in the doctrines of their religion. They have not above thirty books, which are Arabic, and all relate to the Mahometan faith. The women are veiled still more closely than is usual in Musulman countries; they even remain covered from their husbands for three years after marriage. Job, at leaving Africa, had not seen the face of a wife, to. whom he had been two years united. The chief employment is agriculture, which is very laborious, as they have no instruments proper for it, and no means of reaping the grain, unless by pulling it up by the roots. Elephant hunting is generally practised, and produces a considerable quantity of 
ivory for trade. Both in war and hunting, they make use of arrows poisoned, by being dipped in the juice of a certain herb. Job asserted, in the most positive manner, that the Senegal and Gambia flowed always parallel to each other, and never united; a correct statement, which met little credit in $\mathrm{Eu}-$ rope, on account of the opposite geographical system, which was there universally established.

We come now to the travels of Moore, who, though he did not penetrate so deep into the interior as some of those already mentioned; yet, from the length of his residence, and his intimate communication with the natives, collected, on the whole, more information respecting this part of Atrica, than any traveller prior to Park. He was employed by the African Company as their factor, or superintendent, at the different trading stations on the Gambia, and in travelling from one to the other, had ample opportunities of observing whatever was most worthy of notice throughout this region. He begins with giving some account of the nations who inhabit its banks, particularly of the Foulahs, whom he terms Pholeys. He mentions them in much more respectful terms than Jobson. According to him, they are a truly meritorious and industrious race; and " to have a Pho" ley town in the neighbourhood, is by the natives " reckoned a blessing." Their villages form a spe. 
cies of independent republic, governed entirely by their own chiefs, without any dependence upon the sovereign of the district. If they are oppressed or encroached upon, they remove themselves, and the benefits of their industry, to another territory. Even the king of Barsally, the most imperious and absolute of these chieftains, "does not dare to med"dle with them." Our author is never weary of extolling their good qualities; their hospitality, mildness, and humanity, not only among themselves, but towards the other inhabitants; to which they add the quality of intrepid courage, whenever any aggression requires its exertion.

Moore resided for some time at James-Fort, with occasional excursions to the neighbouring towns. Tancrowall, at some distance up, he describes as of considerable size, and the richest town on the whole river. It was inhabited partly by Mandingos, and partly by Portuguese, who occupied separate divisions, and built their houses in a different style. Those of the natives are conical, about twenty feet in diameter, and eight feet high, of " a good fat binding clay, which soon hardens," and the roof covered with ciboa or palmeto leaves. Albreda is a considerable town, about a mile below James-Fort, where the French have a factory. In consequence of this situation, their passage up the river is commanded by the English fort, and they were permitted to carry on trade only upon 
condition of not giving more than forty bars a head for each slave. When they wished to pass JamesFor't for a supply of wood or other necessaries, they were obliged to apply to the English governor, who, in granting permission, put one of his men on board, to observe that they did not engage in any trade.

After some residence at James-Fort, our author was sent up, along with a Mr Roberts, to superintend the factory at Joar. He had not been long here, when they were honoured by a visit from the king of Barsally, (Bur Salum,) the most powerful sovereign in this part of Africa, and on whom most of the others are dependent. This prince had a very commodious house of his own in the town, but found it more eligible, for reasons that soon appeared, to take up his abode in the factory. Here his majesty began by taking possession of the apartment and bed of Mr Roberts, and soon shewed his expectation that every thing which the factory contained should be at his disposal. Some reluctance being shewn to meet his views in this particular, he, at the advice of his courtiers, caused Mr Roberts to be held, while he took from him the key of the storeroom, which was immediately searched for every thing that could afford gratification to the royal palate. "Brandy "was his main hank," of which he found an anker, which kept him for three days in a state of mostcomfortable intoxication. The supply being exhausted, 
every corner was eagerly ransacked for more, but without effect. At last they came to a small apartment, where Harrison, one of the servants of the Company, was lying ill in bed. Here the monarch descried a case, which wore somewhat of a promising aspect ; and inmediately ordered it to be opened. Harrison protested that it contained nothing but some papers of consequence, which he had strict orders to allow no one to inspect. "The king "was too well acquainted with liquor cases to be "put off so ;" he therefore caused his attendants to hold Harrison while himself took the key from his breeches pocket, and opened the case, which, to his infinite delight, was found to contain six gallons and a half of excellent brandy. This gave rise to a new and unremitted scene of bacchanalian festivity; though Moore candidly admits, " he must do the king this justice," that he frequently invited Mr Harrison and himself to a share of their own liquor. When the whole was exhausted, and there appeared no prospect of a new stock being discovered, the party began to talk of taking leave. Before their departure, however, the king, his generals, and ministers, made a new survey of the premises, and amused themselves with pocketing every thing, the possession of which appeared convenient or agreeable. "What resistance could " three men make against three hundred?" The entire spoil upon this last occasion, however, did 
not amount to much more than twenty pounds; and they had then the satisfaction of bidding adieu to their illustrious visitors.

The king of Barsally, as well as all his attendants, are zealous Mahometans; and whenever he was not completely intoxicated, he prayed most fervently. Far from thinking, with others of his persuasion, that it was worse than death to taste brandy, or other strong liquors, he considered it almost as deadly an evil to taste any thing weaker. His usual course of life was, to rise at night, and drink till towards daylight, then eat, and go to sleep till near sunset. At that time he rose, and having again drank copiously, went to sleep till midnight. His insatiable thirst for brandy kept both his subjects and neighbours in a state of perpetual terror. When he stood in need of a supply of this indispensable article, he immediately sent to the managers of the Company at James-Fort, requesting that they would dispatch a cargo to be exchanged for slaves; a call which those worthy personages always obeyed with the utmost alacrity. The king then marched suddenly to a neighbouring town, set fire to three parts of it, and stationed his guards at the fourth, who seized the inhabitants as they attempted to escape. If he was not at war with any of his neighbours, he then, says Moore, "falls upon one of his own towns, which are " numerous, and uses them in the very same man- 
" ner." One of the amusements of this august personage, was to go on board a vessel in the river, and shoot at the canoes as they passed; and frequently one or two in the day were killed in this pastime. He alone, of all the sovereigns in this quarter of Africa, is entirely absolute, and lies under no obligation to consult with his subjects or chief men. The chiefs under him are called Boomeys, and possess almost the sole power in their respective villages; but they are obliged to serve the monarch in war, and once a year come to pay homage to him.

Soon after this period, violent dissensions arose between Moore and Roberts, the joint managers of the factory at Joar. Roberts even left the factory, and took up his residence at Cower, a large negro town, about three miles distant, from whence he instigated the negroes to insult, and even rob Moore. The Company seem at first to have entertained some doubt on which side the fault lay. They were particularly dissatisfied with the large defalcations in the warehouse, and strongly suspected that the king of Barsally had been made responsible for a few more misdeeds than he had really committed. They at first, therefore, superseded both. But they afterwards became sensible, that the blame rested with Roberts, who was recalled; and Moore, as he became known, was treated more and more as a confidential servant. He was thence- 
forth sent successively to the different factories whenever any thing important was to be transacted. He was at this time sent up the river as far as Fatatenda. He came first to Kassan, of which. he gives a description nearly similar to that of Jobson. It seems " this was a noted town for doing " mischief;" and Europeans could scarcely pass through without receiving some insult; but in consequence of having recently been taken and plundered by a neighbouring potentate, the character of the people was entirely changed ; they were become " the civilest in the whole river ;" and the town might be passed through with perfect safety. The vessel then passed by Brucoe, (Bruko,) where. there was an English factory building. About nine miles was Dubocunda, composed of two towns, one. of which was open, and the other fortified by trees fixed in the ground, and clay stuffed in between them. This last served as a refuge when they were hard pressed in those extremities of war, to which their turbulent disposition often exposed them. They had lately rebelled against the lawful emperor (as he is termed) of Jemarron, had driven him to the extremity of his dominions, and elected a king of their own. Moore then passed Cuttejarr, formerly containing a factory, which had, been removed, in consequence of its being overflowed by the Gambia. In passing up the river, he was visited by a Mumbo Jumbo, of which he 
gives a very particular account. He says, "It is " dressed in a long coat made of the bark of trees, " with a tuft of fine straw on the top of it. This " is a thing invented by the men to keep their " wives in awe, who are so ignorant (or at least are " obliged to pretend to be so) as to take it for a " wild man." The sound, indeed, is said to be so dismal, that only the most positive assurance to the contrary could make any one suspect that it issued from a human voice. Whenever any dissension takes place within the domestic circle, this umpire is speedily called in, pronounces and executes sentence, almost invariably against the weaker party. During the day, the coat is hung on a long pole, in order to be ready whenever its services are required. Youths are initiated into this society at the age of sixteen, but bound by the most dreadful oaths never to divulge its arcana. to any female. It seems, that about the year $172 \%$, the wife of the king of Jagra, being endowed with more than the usual curiosity of her sex, wrested from her husband this fatal secret. The faet having transpired, a council of the men was immediately held, to consider in what manner it would henceforth be possible to keep their wives in subjection. A signal example was judged indispensable ; and the fact being proved, both the king and queen were put to death, as a warning to all who should ever again 
seek or allow others to pry into so awful a mystery.

Our author now proceeds to Nackway, which seems to be near the present situation of Pisania, and where he was appointed to inspect the behaviour of a Portuguese servant employed by the Company. Here he remarks, that the behaviour of the natives by no means corresponded to the unfavourable reports spread of those who inhabited the upper parts of the Gambia. As he passed through their towns, most of the inhabitants came and shook hands with him, and only the women who had never before seen a white man, ran away and hid themselves. He mentions, however, some singular customs that prevailed. It.seems, that whatever a man buys may be reclaimed in the course of the day, on the price being returned. This custom sometimes affords a handle for extortion against those Europeans who are not aware of its existence. A gentleman having bought a cow, happened soon after to cut off the tail. This coming to the ears of the seller, he immediately came, and, on some plausible pretext, requested its restoration. The animal being produced, he immediately exclaimed against the mutilation it had suffered, and demanded, as a compensation, three hundred times the price originally paid. The gentleman remonstrated against a claim so manifestly unjust; but, finding his opponent seconded by the whole popu- 
lation, he yielded to the law of the strongest, and paid the sum demanded. However, having returned some time after with a well armed ship, and induced several of the principal people to come on board, he threw them into irons, and kept them until full restitution had been made. They candidly acknowledged, on this occasion, that "they "were justly served;" and continued their intercourse with him in the same cordial footing as before.

From Nackway, Moore proceeded up the river to Fatatenda, the highest point at which the Company have ever established any factory. The Gambia was here about the breadth of the Thames at London Bridge, and being in October, the end of the rainy season, it ran with a deep and rapid stream. The factory was situated on a high rock close to the river, and commanded a pleasant prospect over great part of the kingdom of Cantore. The plain round it, however, echoed continually with the roaring of wild beasts. Hamilton, the factor, was here entirely by himself, and had not seen a white man for two months. He was frequently favoured with the visits of the king of Tomany, who seems to have been a complete counterpart of his Barsallic majesty. Every thing in the shape of brandy was invariably seized, and the factor, when he obtained any for his own use, had no resource but to bury it in the 
woods, and steal to it at midnight, as the miser to his gold.

Moore takes occasion here to enter into some particulars respecting the manners of the Mandingoes. The cultivated ground adjoining to each village is divided into two large fields, one for corn, and the other for rice. These are tilled under the direction of the alcade, or chief magistrate, who appoints to each their.portion of labour, and the produce is then divided according to their respective wants, so that it is scarcely possible that any one can starve in a Mandingo village. The alcade also decides all differences, and has the first voice in all deliberations respecting matters of general concern. The merchants, and particularly the Europeans, are considered as under his peculiar protection; hence he is usually called Tobaubo Mansa, "the white man's king;" and Moore observes, that any one who can keep well with him, is pretty sure of having his business well done.

The accounts of marriage, polygamy, \&c. among the negroes, are pretty nearly the same as those given by all travellers. The wives are under great subjection to their husbands, which our author ascribes in a great measure to the influence of Mumbo Jumbo. He knew a pretty large town near Bruko, which contained only one man, his wives, children, and slaves. The women are generally married very young; the price of one is 
two cows, two iron bars, and two hundred Kolla nuts. The marriage feast is open to the whole neighbourhood, and generally continues for three or four days. Each wife lives in a separate hut, all the contents of which, both furniture and provisions, being produced by her industry, are considered as entirely her property, with which the husband has no interference.

Every person who dies is considered as having met his fate, either through the agency of witches, or as a punishment for some vow which he has violated. One man having vowed never to part with a particular male slave, was afterwards, through the necessities of his family, obliged to sell him; but however urgent the motive was, it did not prevent his sudden death from being imputed to this perjury. Among their superstitious practices, may be mentioned the mode of trial, by making the accused dip his hands into scalding water; when, if the natural effect be produced, he is immediately concluded guilty. An English captain was so far enamoured of the native customs, as to adopt this mode of judicial investigation. Having missed a gun, he caused his crew to put their hands into boiling water, by which, it seems, " they scalded. " themselves miserably." As he was triumphing, however, in the success of this mode of detection, he unexpectedly discovered the gun in his own 
custody; which, coming to the ears of the crew, very naturally gave rise to a mutiny.

As Moore resided so long in this part of Africa in the capacity of factor, his account of the commerce upon the river is perhaps the most valuable which we yet possess.

The Gambia is navigable for sloops six hundred miles from its mouth, to the falls of Barraconda. To that point also the tide ascends, which he remarks is higher than in any other river with which he is acquainted. The lower parts are flat and woody; but the upper rise into hills of considerable height, composed of iron-stone. The value of European goods is expressed by bars, an imaginary denomination, expressing a certain quantity of each species of commodity. A pound of fringe, two pounds of gunpowder, an ounce of silver, and a hundred gun flints, are each equal to a bar. There are certain articles called "the heads of the "goods," being those alone for which there exists at all times a sure demand. These "heads" are spread-eagle dollars, crystal beads, iron bars, brass pans, and arrangoes. Into the price of every slave, there must enter a certain number of heads. The articles received in return are chiefly gold, ivory, bees-wax, and, above all, slaves. The gold is of good quality, finer than sterling ; it is brought in small bars, large in the middle, and turned round into rings of the value of from $10 \mathrm{~s}$. to $40 \mathrm{~s}$. 
Great mystery is observed by the merchants as to the places where the gold is obtained. The ivory, or elephants' teeth, is generally brought from a considerable distance inland. It is obtained either by killing the animal, or by finding the teeth in the woods. They are esteemed according to their size ; one of 100 lbs. being of more value than three that together weigh 140 lbs.

The grand object of this commerce, however, is slaves. These also are brought chiefly from the interior, and consist of Bumbrongs (Bambarrans) and Petcharies. They are bound together with leather thongs, and walk thirty or forty in a string, at about a yard's distance from each other. In their.way, they travel through extensive woods and wastes, (the Jallonka wilderness of Park,) and are obliged to carry with them both wood and water. The merchants who conduct this trade are of the Mandingo race, commonly called Joncoes; and amount in number to about a hundred. As to the mode of procuring the slaves, they are either those taken in war, those condemned for crimes, "or " else people stolen, which is very frequent." The Company's servants piqued themselves upon never buying any of the last, "till after a consultation "with the alcade," which we suspect had their own security only in view. All offences, from the lightest to the most atrocious, are punished alike with slavery; " and they strain for crimes very 
" hard, in order to get the benefit of selling the " criminal." It is, however, considered very culpable to sell a family slave; and Moore never knew but of one who was so disposed of, unless for crimes which would have involved a free man in a similar fate. The family slaves are well treated, and in many cases scarcely to be distinguished from their masters. 


\section{CHAPTER IV.}

TRAVELS IN THE SAHARA, OR GREAT DESERT.

General View of the Great Desert.-Adventures of Saugnier.

-The Monselemines.-The Mongearts.-Brisson.-The Ouadelim and Labdesseba.

The Great Desert, or Sahara, comprehends all that extent of land which lies between the narrow stripe of Barbary, and that fertile track, stretching across the centre of Africa, which Europeans term Nigritia, and the Africans Soudan and Affnoo. It presents a surface equal in extent to nearly one half of Europe, containing islands of great fertility and population, from which its different parts derive their names, as the deserts of Barca, Bilma, Bornou Sort, \&c. Its western division, contained between Fezzan and the Atlantic, is about $50 \mathrm{ca}$ ravan journeys, or from 750 to 800 geographical miles in breath, from north to south, and double that extent in length. Amidst this vast sea of lifeless sand, the islands, or Oases, as they were termed by the ancients, are extremely few, and of small extent; but they are more numerous in the eastern division, where, besides many small ones, 
there are Fezzan Gadamis, Taboo, Ghanat, Agadez, Augela, and Berdoa. The inhabitants of these Oases are sometimes isolated for ages from the rest of mankind. Having never seen any people but their countrymen, nor any other part of the earth except the sands by which they are surrounded, they consider themselves as the only nation in the world, and think the boundary of their land that of the universe. Messrs Saugnier and Brisson, who, in 1784 and 1785, traversed that part of the desert which lies upon the Atlantic, have described the manners, customs, and modes of life of its inhabitants, with greater accuracy than had been done by any other traveller, though; from their peculiar situation, we may expect the picture to be rather overcharged.

M. Saugnier, in a voyage to Senegal, was shipwrecked off the mountains of Wel de Non, in the country of the Mongearts. After being plundered, he and his companions were separated, and enslaved by the Mongearts and Monselemines. $\mathrm{He}$ was conducted by some Arabs towards Senegal; but, from the hostilities of some of the interjacent tribes, they found it impossible to proceed beyond Cape Blanco, and were forced to return to that part of the desert which separates the Monselemines from the Mongearts. During this journey, which continued 30 days, his food consisted only of milk mixed with camels' urine, and a little bar. 
ley-meal mixed with brackish water, when it could be procured. On the first day, his steps were marked with blood; but the Arabs drew out the thorns from his feet, and, having scraped his soles with their daggers, plastered them over with tar and sand, which enabled him to walk without farther pain or difficulty. In that part of the desert which he traversed, he observed much excellent land, that would be very fertile if cultivated. It produced great quantities of truffles, which the Moors, with much humanity, denied to themselves, and gave to M. Saugnier. He was employed, when he resided at the horde, in making butter, by shaking the milk in a goat's skin, and in collecting dead wood; for, though the country was covered with bushes, the Arabs never touched a green stick. M. Saugnier had not remained long in this situation, till he was sold to one of the Moors, who at that period were in rebellion against the Emperor of Maracco, for a barrel of meal, and an iron bar about nine feet in length. During a journey of nine days, he ate nothing but small wild fruits resembling jujubes. After being repeatedly sold, he rescued his master from being assassinated by four Arabs, from which moment his sufferings were at an end, and he was treated as one of the tribe. But, as he refused to renounce his country, he was again sold to the chief of Glimi, who then commanded the Moors who were in rebellion against 
the emperor. During his residence in Glimi, having better diet and clothes, he recovered his strength, which had been exhausted in the desert; and relates, that when he asked victuals from the women, he never was refused. The French merchants at Mogadore, having been informed of the distress of their countrymen, with the English merchants resident in that place, employed an Arab to purchase the liberty of as many as could be found. Six were accordingly redeemed; but, upon their arrival at Mogadore, they found themselves exposed to the childish petulance of a barbarian prince. As the Emperor of Marocco, only two months before, had given the most positive orders to his governors of provinces, in the vicinity of the desert, to use every method of extricating them from the wandering Arabs, he was extremely chagrined, that, in his own dominions, Christians had been able to accomplish what he had found impossible to effect. He therefore threatened to burn the first person alive, who, from that time, should dare to interfere in the redemption of a captive of any nation; and, repaying the money which had been advanced, obliged the merchants to resign M. Saugnier and his companions, and caused them to be conducted to Marocco. Upon their arrival they were treated with unexpected kindness by the emperor, who immediately granted them their liberty, and allowed them to return 
to France by Tangier, from which they sailed on the 31 st of July 1784. The acquaintance with the manners of the Arabs of the desert, which $\mathbf{M}$. Saugnier obtained, during his residence in the $\mathrm{Sa}$ hara, proved afterwards, as we have seen, of the greatest utility in his voyage up the Senegal to Gallam, when one of his vessels was stranded on the territory of the Trasarts, a Moorish tribe, and enabled him to preserve his property. His delineation of Nomadic manners appears to be fair and accurate, and untinctured by the prejudices of civilized society.

Of the Monselemines.-That part of Bilidulge: iid which borders on the territories of Marocco, is inhabited by the Monselemines, who differ in their religion and customs, both from the Moors of Barbary, and the Mongearts of the desert. This nation is composed of the descendants of the ancient Arabs, intermingled with fugitive Moors from Marocco, and occupies a space of land, the limits of which are indicated by lofty columns placed at intervals, towards the desert. Their territory extends from about 30 leagues beyond Cape Non, to the distance of 20 leagues from St Croix, or Agadeer. Though of different qualities, it is, for the most part, very fertile, and produces the necessaries of life with little cultivation. The plains are watered by an infinite number of streams, and abound with palm, date, fig, and almond.trees. 
The gardens produce excellent grapes, which are dried by the Arabs, and converted into brandy by the-Jews. Great quantities of oil, wax, and tobacco, appear in the public markets. More indus. trious and more laborious than their neighbours, the Monselemine nation cultivates the earth. . The chiefs of families choose the ground most fit for cultivation. Its surface is turned slightly over with a kind of paddle, and then the seed is sown upon it; the field is surrounded with bushes, to mark the spot, and to preserve it from the cattle of the wandering Arabs. When the crop is ripe, which is generally at the end of August, three months after the sowing of the seed, it is cut about six inches from the ear, and formed into little bundles; during which time every one labours, without in. termission, from morning to night. The corn is brought before the tent, threshed, winnowed, and placed in the magazines. When the harvest is over, they set fire to the long stubble, and abandon the field for two or three years. Their magazines are large holes in the earth, formed like the frustum of a cone, the insides of which are hardened by burning wood in them, before the half-winnowed corn be deposited. When filled with corn, they are covered with planks placed close to each other, over which a layer of earth is laid level with the soil, to prevent it from being discovered by enemies. In these magazines, every one shares in 
proportion to the number of men he employed in the common labour. The inhabitants of the plains remain by the cultivated fields in seed time, and return at the time of harvest. During the intervals they wander in all directions with their cattle, taking only necessaries along with them, and having recourse to the magazines when they require a supply. This manner of life, which is adopted by the people of the country, may be considered as intermediate between the pastoral and agricultural states, and is very similar to that of the common people in Wales, Scotland, and Ireland, in the 15th century. The more opulent people, and the artisans who are engaged in sedentary occupations, dwell in towns which are all situated upon the declivity of hills. Their houses are built of stone and earth, according to the Moorish construction, low and covered with sloping terraces; yet they are so much injured by the heavy rains which prevail for three months of the year, as to be rendered uninhabitable in 15 or 20 years. Those who reside in towns are generally weavers, shoemakers, goldsmiths, potters, \&c. and have no cattle; but the more opulent persons have flocks and herds of cows, horses, camels; sheep; goats, besides poultry, which are kept by their slaves at a distance from the towns. In the towns they take two meals a-day, one at 10 o'clock, and the other at the setting of the sun, though the in- 
habitants of the country only eat in the evening. 'They sleep in mats upon the floors of their apartments, and make use of linen; but the inlabitants of the country sleep upon terraces in the open air. The pastoral families of the country practise hospitality like those of the desert, and make the traveller pay nothing for his entertainment. In the towns, this practice is impossible, as the concourse of strangers, especially on market-days, would soon impoverish the inhabitants. In this manner hospitality is always extinguished among a trading and commercial people. It is only where the superfluity of commodities runs necessarily to waste, that it is ever practised in a great extent; but where every commodity can find a market, every kind of property acquires a definite value, and will be preserved with the same care as money.

The government of the Monselemines is republican, and they choose new chiefs every year. In the time of war, the chiefs are selected indiscriminately from among the natives and the fugitive Moors. Their authority, like that of the Sachems of the American Indians, terminates with the campaign; but during this period it is absolute. The country is populous, and would be still more so, were it not the continual wars which its inhabitants are obliged to support against the Emperor of Marocco. The Monselemine, richer than the subjects of Marocco, is always well clothed and armed. He 
pays no tribute, enjoys the fruit of his labour and commerce, and, as no contributions are requisite for the charges of the state, whatever he acquires is his own. The fugitive Moors are never armed, except when they go to battle; but the natives go continually armed, whether they reside in the country, resort to the markets, attend the assemblies of the nation, or pay visits. As the Monselemine territory is the retreat of the rich Moors who wish to fly from the tyranny of the Emperor of Marocco, they are too well acquainted with the Moorish customs to be surprised by that prince. No sooner does a Moorish army take the field, than the inhabitants of the country cantons mount their horses, and occupy the passes of the mountains, while the women and slaves, escorted by a sufficient number of warriors, retire to the interior parts of the country, or, if they be hard pressed, to the desert. Among the pastoral tribes, therc are many that addict themselves entirely to arms, and serve as cavalry in the time of war. During peace, they escort caravans, or exercise themselves in military evolutions, and the management of their horses. Being almost always on horseback, and wearing no boots, they have a callous lump on that part of the leg that comes in contact with the iron of the stirrup. 'Their horses, which they break in an admirable manner, are the best in the world; as they are treated with great care by their masters, 
they know them, and are obedient to their voice, and will admit no stranger to mount them.

of the Mongearts.- The most considerable tribes that inhabit the Sahara are the Mongearts, the Trasars or Trargeas, and the Bracnarts. The Mongearts, an the north border, upon the territories of the Monselemines, and occupy that extent of coast which reaches from Cape Bojacior to Cape Blanco. Though shepherds like the Monselemines, they are not so warlike, nor so much versed in arms, as they procure their subsistence with much greater difficulty, while their mutual jealousies, and the barrenness of the country, prevent them from forming a general confederacy. The Trasars and Bracnarts, who inhabit more fertile tracks on the northern banks of the Niger, are more closely united as communities, and consequently more formidable to their neighbours. The information of M. Saugnier is corroborated by $\mathrm{Mr}$ Park, who, during his residence in Ludamar, was told that the Moorish tribes of Trasart and Il-Braken were more powerful than those of Gedumah, Jafnoo, and Ludamar. These tribes only differ from the Mongearts in some trivial customs which they have derived from their intercourse with the negroes. That part of the desert which the Mongearts inhabit is parched and uncultivated. The flying sand, comminuted into the smallest particles, drifts with every gale, and rises, at times, into high 
mountains, which soon disappear as the winds blow. Shifting for a succession of ages, it is soon deposited in mounds, at regular intervals, which arrangement produces a continual succession of sand-showers, except when the air is entirely stagnant. When the sand-shower reaches the tents of the Arabs, they load their camels, turn their backs to the gale, and haste away; which precaution alone can preserve them from being buried alive. This flying sand is the great obstacle to cultivation, for the soil of the desert is not every where unproductive.

M. DE BRIsson, after having made several voyages to Africa, was wrecked a little to the north of Cape Blanco, and fell into the hands of the Labdes. seba Arabs. After escaping the shoals, his companions and he ascended the rocks on the shore, from the summits of which they saw the country expand in an immense plain, covered with white sand, over which were thinly scattered a few creeping plants resembling branches of coral. The seed of these plants was similar in form to that of mustard, but extremely small. The Arabs, who collect it to form an edible paste, term it avezoud. The distant hills, covered with wild fern, presented the appearance of an extensive forest. Proceeding towards some camels which they observed, they were discovered by some children tending the goats, and the alarm was soon spread to the tents of the 
Arabs, who quickly advanced to meet them with frightful shrieks and gesticulations. Terror seized the companions of M. de Brisson as the Arabs advanced; and the polished steel of their weapons reflected the sun-beams; they dispersed themselves in confusion ; and were quickly overpowered, stripped, and plundered. Brisson and eleven others surrendered themselves to the Talbe, or priest, who was unarmed, and were conducted to a wretched hut, covered with moss, at the distance of a league from the shore. Here, during the absence of Sidi Mahomet, the priest, who was of the tribe of Labdesseba, they were attacked and maltreated by a party of the Ouadelims, and, during the bustle which ensued, Brisson had almost lost his life. Instead of compassionating his forlorn situation, the women threw sand into his eyes, as they said, to dry his eye-lids. The Arabs, into whose hands he had fallen, had only come down to the sea-coast to gather wild grain, three days before the shipwreck; and, to preserve their booty, they immediately retreated to the interior of the desert. A guide preceded the horde, to place at intervals small pyramids of stone, to direct their course, at a distance from every hostile tribe. After passing some very high mountains, wholly covered with small greyish pebbles, as sharp. as flints, they descended into a sandy plain overspread with thorns and thistles. When Brisson was unable to walk, on account of VOL. I. 
the bleeding of his feet, he was mounted on a camel, the bristly hair and hard trot of which soon excoriated him so much, that the blood ran copiously down its flanks. By throwing heated stones into a wooden vessel, filled with barley-meal, diluted with water procured on the sea-shore, preserved in a goat's skin, and mixed with pitch to prevent putrefaction, the Arabs prepared a kind of soup, which they kneaded with their liands, and ate unchewed. They roasted a goat in heated sand, ate its fat raw, and, after having devoured the flesh, gnawed the bones, and scraped them with their nails, threw them to Brisson and his companions, desiring them to eat quickly, and load the camels, that the journey might not be impeded. Proceeding eastward, they crossed a vast plain, covered with small stones, white as snow, round and flat as a lentil, where not a single plant was produced. The earth beneath their feet resounded dull and hollow, and the small stones pricked them like sparks of fire. The reflection of the rays of the sun from the sand was scorching; the atmosphere was loaded, with a red vapour, and the country appeared as if filled with flaming volcanoes. Neither birds nor insects could be seen in the air. The profound silence was frightful. If a gentle breeze ever arose, it produced extreme languor, chopping of the lips, burning heat of the skin, with small smarting pimples. This plain was even shunned by wild beasts. After traversing 
this plain, they entered another, where the wind had thrown up in furrows the sand, which was of a reddish colour. On the tops of the furrows grew a few sweet-scented plants, which were devoured by the camels. On quitting this sandy plain, they entered a valley surrounded by mountains, where the soil was white and slimy, and where they found water of a noxious smell, covered with green moss, and soon after discovered a horde of the friendly tribe Rousaye. Sidi Sellem, one of the chiefs of this horde, and brother-in-law to Sidi Mahomet, proposed to Brisson to put himself under his protection, and offered to purchase him ; to which Brisson, who expected soon to reach either Senegal or Marocco, gave a firm refusal. After another journey of sixteen days, they arrived at the tents of the Labdesseba horde, to which Sidi Mahomet belonged. The tents, pitched among thick bushy trees, and the numerous flocks feeding along the sides of the hills, presented at a distance an aspect of happiness and pastoral simplicity. On approaching near, the trees of beautiful green foliage proved to be only old gummy stumps, almost void of branches, so encircled with thorns, that their shade was inaccessible. The women approached with loud cries and the most fawning servility, to welcome their tyrants, to throw stones at the Christians, and spit in their faces, while the children imitated the example of their mothers. Brisson, 
who endeavoured to ingratiate himself with his master's favourite, not only failed in this, but incurred her implacable resentment, through his irritability, which, to the Arab women, seemed extremely to resemble petulance. During his residence with Sidi Mahomet, the hardships he endured were almost incredible. With the excessive heat, the milk of the sheep, goats, and camels diminished, and then the dogs fared better than the Christians, who were forced to subsist on wild herbs and raw snails. When the rains fell, and the least. pressure made the water to spring up through the sandy soil, the Christians slept behind a bush, unsheltered, on the bare ground. Brisson and his master sometimes reasoned about religion, when the latter always answered the harangues of the former by declaring, that he preferred a bowl of churned milk to such absurdities. Several of his companions perished, and were left by the Arabs to be devoured by the ravens, while in the struggles of death. One of them was supposed to be murdered by his master, for milking his camels clandestinely. An application made by Brisson to the council at Mogador, by a letter entrusted to a Jewish merchant, was frustrated through the negligence of the vice-consul; and the Labdesseba Arabs thought the journey too dangerous to be encountered for the ransom of their slaves. The drought became so excessive, that no pasturage 
could be found for the flocks; upon which the tribes of Ouadelim and Labdesseba, after holding a consultation, determined to go in search of new habitations. The horde to which Brisson's master belonged was one of those that remained behind, while the Ouadelims extended their ravages to $\mathrm{Gu}$ adnum, at the distance of 300 leagues from their former residence. Those who remained behind subsisted for a short period, but were soon reduced to the utmost extremities, by the failure of pasturage and water. They were forced to kill their camels and goats, in order to obtain the water in their stomachs, which was of a greenish colour, and extremely disagreeable. In this dreadful situation he was purchased by Sidi Sellem, the brother-in-law of his master, with whom he immediately departed for Marocco. On their journey, the appearance which the country presented was uniform and wild. Wide sandy plains," terminated by a bare horizon of black rocky hills, filled up this blank in nature. The plains were covered frequently with calcined flints resembling a smith's charcoal. In one place they observed some whitish earth, over which the trunks of trees were heaped in confusion, with their roots torn off. Their bark was entirely peeled, and their branches, brittle as glass, were twisted like cords. Their wood was yellowish, like the wood of liquorice, and the heart of the trees was filled with a powder very 
hard to the touch. Neither the wood, nor the enclosed dust, nor the calcined stones, had either taste or smell. At some distance, the mountains, which were extremely high, seemed to be piled above each other in immense ranges, from whence enormous blocks appeared to have fallen, and to have been shattered to pieces before reaching the ground. These detached masses, over which other rocks hung suspended, formed immense caverns, and covered the valleys. From another quarter, two fountains issued, one of which drew along in its course a black slimy matter of a sulphureous smell. The other, separated from the first by a small isthmus of sand, of the breadth of 12 or 15 paces, was : clearer than crystal. In a valley, which appeared at first sight extremely circumscribed by the surrounding mountains, and the detached rocks which were heaped up in promiscuous confusion, Brisson discovered an astonishing variety of scenery. At the entrance of the valley, the ground was moist and furrowed, as if it had been formerly watered by winding rivulets. The borders of these furrows were covered with beds of pebbles, and crusted over with a nitrous kind of ice. The rocks which enclosed the furrows were covered with the same, and resembled cascades. Thick reddish roots and branches, covered with leaves like those of the laurel, crept across the different crevices. As he advanced, pyramids of great stones, white 
as alabaster, appeared towering above each other, and seemed to mark the border of a bank. Lofty date trees, whose trunks were warped even to the top, rose behind the pyramids, with palm trees, the height and colour of which exhibited proofs of their high antiquity. Others of these were thrown down, and lay stripped of the bark; they crumbled to pieces upon being touched; and the filaments under the bark were covered with a saltish powder clear as crystal. The roots which hung down the rocks were glutinous, and the bark broke off at the slightest touch. Advancing nearer Marocco, they found lofty mountains covered with stones of rose, violet, citron, and green colours; and observed forests at a distance. On their approach they were astonished to see the trunks of trees descending from the centres of rocks, and apparently hanging down. like fruits, while the roebucks coursed, one after another, over the hanging rocks, and the trees that hung suspended in the air. Brisson remarks, that no trees in these forests are injured by lightning except one, the leaf of which resembles that of the gum tree, or common parsley. Before reaching Gruadnum, they arrived at the habitations of the tribe Telkoennes, who reside among mountains of sand, as if they endeavoured to hide themselves from the light of the sun. It is almost impossible to penetrate their retreats, unless a person be acquainted with the passes of the sand- 
hills. The plains in their neighbourhood swarm with enormous serpents. At last, they reached Guadnum, the asylum of the most daring rebels of all the Arabian tribes, the mart of the inhabitants of the desert, who come there to barter their camels, peltry, gum, \&c. for woollen stuffs, half white and half crimson; for wheat, barley, dates, horses, tobacco, gunpowder, combs, and mirrors. This trade is entirely carried on by the Jews. The inhabitants live in a state of mutual distrust; their houses are guarded by large dogs, and also their persons, when they walk through the city. Leaving Guadnum, they arrived at Mogadore, and were delivered up to the governor, who sent them with an escort to the emperor at Marocco, by whom Brisson was soon after set at liberty. The character of the inhabitants of Marocco differs little from that of the Arabs of the desert: They are not of so stout a make, but of a fairer complexion; more accustomed to the sight of Europeans, but equally addicted to insulting them. The earthen ruinous walls of the palace resembled the enclosure of a chuich-yard; the outside of the seraglio was not unlike a barn; and the houses of the city of a very bad construction. The narrative of Brisson represents the Moors and the Arabs of the desert in the most unfavourable point of view. Inflamed with resentment at the insults to which he was exposed from the religious bigotry of the Mahome- 
tans, and soured with the hardships he endured in the desert, to which the Arabs were equally obnoxious, but which they were more able to encounter, he gives every circumstance the most malicious construction. To a Frenchman of fine feelings, that appearance of insensibility which misery produces, assumed the form of deliberate cruelty. The general outline of the picture he delineates seems to be sufficiently correct, but the minute figures are probably in the style of caricature. Like a certain painter of the Flemish school, he cannot be charged with wilful exaggeration; but the rancour of his ulcerated mind darkened the faces of his devils, and gave their features a peculiar expression of malice. As he traversed some of the districts of the desert, at a great distance from the shore, his remarks on the manners of the Arabs who inhabit the interior are extremely interesting.

Of the Ouadelim and Labdesseba.-Of the inhabitants of the interior regions of Sahara, the Ouadelim and Labdesseba, more properly Wolud D'Leim, and Wolud Abbusebah, are the most formidable, and often extend their ravages to the very gates of Marocco. Their hordes are frequently intermingled with those of the Rousege, Rathidium, Chelus, Tucanois, and Ouadeli tribes, as they have no distinct boundaries, and change their habitations, as the desert affords pasturage and water. They are tall, handsome, stout and vigorous 
men. Their hair is bristled, and their nails, which they often use in battle, as long as claws; large hanging ears, and a long beard, give them a stern ferocious air. 'The Ouadelim, in particular, are fierce, arrogant, and warlike, but soon dispirited by obstinate resistance, especially when they have not a decided superiority in numbers. In their hordes they lodge by families, in tents which are covered with a thick cloth of camels' hair, which the women spin and weave upon a loom so small, that they work sitting on the ground. The furniture of their tents consists of two large sacks of leather, in which they keep old clothes and pieces of old iron, three or four goats' skins for holding milk and water, two large stones for grinding their barley, a smaller one for driving the pins of their tents, an ozier matting, which serves for a bed, a thick carpet for a covering, a small kettle, and some wooden dishes, with pack-saddles for their camels. The person who, besides, these articles, possesses a few horses, camels, sheep, and goats, is reckoned wealthy, as there are many Arabs who only possess sheep and goats. Except sore eyes and the cholic, they are subject to few endemic diseases. The first disorder is caused by the reflection of light from the burning sands of the desert; the other proceeds from the verdigrise which contaminates all their victuals. Their kettles are not tinned, and never washed, so that they are 
quite crusted over with verdigrise, the virulence of which is probably diminished by the quantity of milk they use. When they reside long in one place, they sometimes plow the spots which are moistened by the rain, and, sprinkle them with seed in a careless manner. Plentiful crops are often thus produced; but, instead of waiting till the grain attains maturity, they cut it down, and dry it over hot cinders. Treachery and peridy are the innate vices of the Arabs; assassinations are frequent; no man trusts the promise of another; no man makes a written agreement, as the poignard cancels all bonds and obligations. The men often relate their exploits to each other; the embellishing of a story is succeeded by a charge of falsehood, and the poignard solves every difficulty. The ancient rites of hospitality, however, are practised among these tribes, in their utmost extent. The Arab, who, in the field, is a rapacious plunderer, becomes liberal and generous as soon as he enters his tent. War is only a species of rapine, and the victory is decided at the first shock. The Arab is devoid of sanguinary courage; he attacks only to plunder, and never thinks that booty is to be put in competition with his life. When the battle is ended, each party makes graves for the slain, and enclose the tombs with mounds of stones. The ages of the warriors are denoted by the space of ground which the grave occupies, and the fu- 
neral procession is closed by the howls of the femáles.

The women never assume the name of their husbands, and never eat with them at meals. They are faithful to their husbands, and cannot be divorced except by the decree of the seniors of the horde. The Arabs display their opulence by the ornaments of their women, whose ears, arms, and legs, are generally adorned with rings of gold and silver. An Arab beauty must have long teeth shooting out of her mouth, a body extremely thick, and limbs of the longest size. At the birth of a son, every woman, to testify her joy, blackens her face for 40 days. At the birth of a daughter she only daubs the half of her face during the space of 20 days. A mother treats her son with the same respect as her husband, almost as soon as he is able to walk; she prepares his food, serves him, and eats when he has finished his repast. In the education of their young men, the most important acquisitions are dexterity in the use of the poignard, skill in embowelling their enemies with their long nails, and a plausible air in concealing a falsehood. More rude and ferocious than the tribes whose territories lie upon the shore of the sea, the Labdesseba and Ouadelim Arabs are also more confined and illiberal in their ideas, not only believing that they are the first nation in the world, but fancying that the sun rises only for them. 
Brisson relates, that some of them expressed this idea in unequivocal terms. " Behold," said they, " that luminary, which is unknown in thy coun" try. During the night, thou art not enlighten" ed, as we are, by that heavenly body, which re"gulates our days and our fasts. His children* "point out to us the hours of prayer. You have " neither trees nor camels, sheep, goats, nor dogs. "Are your women similar to ours?" "How long " didst thou remain in the womb of thy mother?" said another. "As long," replied Brisson, " as " thou in that of thine." "Indeed," said a third, counting the fingers and toes of the Frenchman, " he is made like us; he differs only in his colour " and language." "Do you sow barley in your " houses ?" said the Arabs, alluding to the ships of the Europeans. "No," said Brisson, "we " sow our fields almost in the same season as you." "How !" cried several, "do you inhabit the " earth? we believed you were born and lived up. " on the sea." 


\section{CHAP'TER V.}

THE AFRICAN ASSOCIATION.

Ins.iution of the Associalion-Ledyard.-Lucas.-Description of Fez:an, Bornou, and Cashna.-Watt and Winterbotton's Journey to Foota Jallo-Major Houghton.

THE year 1788 formed an entirely new cra in the annals of African discovery. Interest only, if not plunder and violence, were no longer the objects with which its secrets were explored. An association was formed of men eminent for rank and wealth, and still more distinguished by their zeal in the cause of science and humanity. The object was simple; - to promote the discovery of the inland parts of Africa, and thus to wipe off the disgrace, which a profound ignorance of those vast regions had so long thrown on the civilized nations of Europe. The plan was, to find out persons, qualified by enterprise and intelligence, to be employed in these scientific missions; and as funds were necessary for this purpose, each individual agreed to subscribe a certain annual sum. The management of the funds, - the choice of the persons to be sent on discovery, -and the requisite correspondence, were entrusted to a committee of the fol- 
lowing persons, chosen by ballot : Lord Rawdon, (now Marquis of Hastirggs), the Bishop of Llandafir, Sir Joseph Banks, Mr Beaufoy, and Mr Stuart. The result of their labours has thrown new lustre on the British name, and widely extended the boundaries of human knowledge. They have thus earned a solid and permanent glory, and have acquired higher claims to the admiration of mankind, than many of those whose achievements fill the first place in the page of history. It is now time, however, to proceed to the details of their operations.

$\mathrm{Mr}$ LEDYARD, the first geographical missionary employed by the association, was of American extraction. Stimulated from his early youth by a violent propensity to explore unknown countries, he had lived several years with the American Indians, and studied their manners and habits; he had sailed round the world with Captain Cook, and had made this voyage in the humble station of corporal of marines, rather than relinquish the adventure. At his return from this expedition, he determined to traverse the vast continent of America, from the Pacific to the Atlantic Ocean, commencing from the north-western coast which Cook had partly explored, and proceeding to the eastern, with which he himself was familiar. Prevented from sailing in a commercial adventure to Nookla Sound, he determined to travel over land to Kamschatka; and for this purpose, after crossing the British 
Channel to Ostend, he proceeded by Denmark and the Sound to Stockholm, from which he attempted to traverse the Gulf of Bothnia on the ice ; but, as the middle was not frozen, was obliged to return. Proceeding from Stockholm into the Arctic Circle, he walked round the head of the Gulf, and descended on the eastern side to Petersburgh. There his extraordinary appearance, wanting both stockings and shoes, and the means of supplying himself with either, procured him an invitation to dine with the Portuguese ambassador, from whom he obtained a supply of twenty guineas on the credit of Sir Joseph Banks, and by whose interest he was permitted to accompany a detachment of stores to Yakutz, 6000 miles eastward, in Siberia. From Yakutz he proceeded to Oczakow on the coast of the Kamschatkan sea, which he was prevented from crossing by the ice, and obliged to return to his former residence for the winter. At Yakutz, he was seized by two Russian soldiers in the name of the empress, and in the depth of winter, conveyed in a sledge through the deserts of Northern Tartary to the frontiers of the Polish dominions, where he was liberated, with the assurance, that if he returned to Russia he would be hanged. In the most destitute condition, he arrived at Koningsberg, where the credit of Sir Joseph Banks again availed him, and he obtained the sum of five guineas, by means of which he arrived 
in England. He waited immediately on Sir Joseph Banks, who communicated to him the views of the African Association, and pointed out the route in which he wished Africa to be explored. Engaging at once in the adventure, Sir Joseph asked him when he would set out : "To-morrow " morning," replied Ledyard, without hesitation. At this interview, Sir Joseph declares that he was struck with the manliness of his person, the breadth of his chest, the openness of his countenance, and the inquietude of his eye. Though scarcely exceeding the middle size, his figure expressed great strength and activity. Despising the accidental distinctions of society, he seemed to regard all men as his equals, and his manners were not disagreeable, though unpolished. His uncultivated genius was original and comprehensive, not modelled by rule, but moulded by circumstance. From the native energy of his mind, ha was adventurous and curious, and unappalled by daingers; but the strength of his judgment united caution with energy. To a man of his description, formed for dangers and daring, the arduous task of traversing the widest part of the continent of Africa, from east to west, in the supposed latitude of the Niger, was assigned. After obtaining hisinstructionsand letters of recommendation, Ledyard sailed from London on the 30th of June 1788, and arrived in 36 days at Alexandria. Proceeding to Cairo, where he ar.

roI. I. 
rived August the 19th, he visited the slave-markets, and conversed with the travelling merchants of the caravans. These sources of information, generally neglected by travellers, enabled him to obtain, at very small expence, a better idea of the African nations, and of their trade, of the position. of places, of the nature of the country, the manner of travelling, \&c. than would have been possible by any other method. When he had announced to the Association that his next dispatch would be dated from Sennaar, in consequence of repeated vexation from the caravan delaying its departure, be was seized with a bilious complaint, which, being incautiously treated at first, frustrated the skill of the best physicians of Cairo, and the attention of M. Rosetti, the Venetian consul.

Though the Lower Egypt, having been often explored, presented no new field of observation, yet many of Ledyard's remarks cannot fail to impress us strongly with the original power of his genius. Of these remarks the most original and striking are subjoined.

Of the Egyptians. - The villages are wretched assemblages of mud huts huddled together, full of dust, lice, fleas, bed-bugs, flies, and all the curses of Moses. The Copts seem the original negrostock, corresponding to that race in the nose and lip ; their hair is curled, not close, like the negroes, but like the mulattos. In Egypt, the colour and 
features vary more than in any country in the same state of civilization. The mummies are covered with the same wampum work that is common among the Tartars. Tattowing is as common among the Arabs, as among the islanders of the South Sea. The women are generally tattowed on the chin with perpendicular lines, descending from the under lip, as is practised by the women on the north-west coast of America. The nails are stained red, as among the Cochin-Chinese and northern Tartars. The Russian and Greek dresses resemble each other, and both the Greek and Russian women wear a fillet round the temples. The same machines are used for diversion as in Russia, consisting of a large wheel, in the extremities of which seats are suspended, in which people are whirled over and under each other. Their music consists of a drum and pipe, both of which resemble these instruments in the South Seas. Their drum is the Otaheite drum; their pipe is of cane, consisting of a long and short tube joined. Whenever the women are present, they make a noise with their mouths like frogs, particularly at weddings. The Egyptian dogs are of the same species found at Otaheite. Among the Arabs he saw a white woman, like the white Indians in the South Sea islands, and Isthmus of Darien. The Arabs engage with a long spear, like the New Zealanders. Those that inhabit the desert have an 
invincible attachment to liberty, like the Tartars; a propensity which can neither be conquered by the arts, nor by any modification of government.

Of the Caravans.-The Mahometans in Africa are what the Russians are in Siberia, - a trading, enterprising, superstitious set of vagabonds ; wherever they are determined to go, they go. As they cannot afford to traverse Africa without trading by the road, they make no voyages merely commercial or merely religious; and where they are not engaged in commerce, they are not to be found. They pass to Sennaar, Darfur, Wangara, and Abyssinia, while they know little or nothing of geography, as they are able to sing, dance, and traffic without it. They trade to Darfur for slaves, gum, and elephants' teeth. The slaves of this nation are of a good form and size, quite black, with the true Guinea face, and curled short hair. The importation of negro slaves into Egypt, in a year, was estimated by M. Rosetti at 20,000. To Sennaar they carry trinkets, soap, antimony, red linen, razors, scissors, mirrors, beads ; and bring back elephants' teeth, gum Sennaar, camels, ostrichfeathers, and slaves. In this traffic the king of Sennaar interferes, and not only is concerned in the Sennaar caravans, but keeps an agent at Cairo to procure and contract for him. Among the Sennaar slaves, $\mathrm{Mr}$ Ledyard saw three personable men, of a bright olive complexion, and intelligent fea- 
tures, whose heads were of a singular structure and uncommon form, exceedingly narrow, long, and protuberant. The Sennaar caravan is the most rich; that of Darfur is' not equally so, though it trades with almost the same commodities. This, however, can surprise no one, who considers that there are numerous circumstances which influence the internal African trade, besides the extent of the journey and the nature of the commodities. The deserts of burning and moveable sand which are to be traversed; the pestilential qualities of the suffocating winds that sweep these arid wastes, which look as if the God of nature had forgot to accomplish the work he had begun; the moral habits and social state of the savage tribes that prowl with the wild beasts over the desert, are not only sufficient to deter the adventurous merchant, but even to damp the ardour of religious bigotry.

Wangara, to which the caravans also traded, was represented to $\mathrm{Mr}$ Ledyard as a kingdom producing much gold; but the king seems to have intermeddled in commerce as well as the potentate of Sennaar; for, in order to deceive strangers, and prevent them from guessing at the extent of his riches, he was reported to vary continually the gold used in barter, which it was his province to regulate, and of which he issued at one time a great quantity, and at others little or none. A. 
caravan goes from Cairo to Fezzan, which is termed a journey of 50 days, and from Fezzan to Tombuctoo, which is called a journey of 90 days. The caravans travel about 20 miles a day, which makes the distance to Fezzan about 1000 miles; and from Fezzan to Tombuctoo 1800 miles. From Cairo to Sennaar is reckoned 600 miles.

These are the principal observations made by Mr Ledyard in Egypt : They display the depth and penetration of an understanding formed by action instead of speculation, warped by no fanciful theories, or prejudices of birth, and accustomed to the living intercourse of men. They must impress every one with deep regret, that he did not live to attempt the arduous enterprise in which he had engaged. The person who, with such scanty funds, could penetrate the frozen regions of Tartary, and subsist among their churlish inhabitants, who could ingratiate himself with the ferocious Moors of Egypt, could hardly have failed of obtaining a kind reception from the gentle and hospitable negro, had no untoward accident intervened. The observations of this accurate observer of man upon the female character, do equal credit to his understanding and his heart. "I have always " remarked," says he, "that women, in all coun" tries, are civil and obliging, tender and humane; " that they are ever inclined to be gay and cheer" ful, timorous and modest; and that they do not 
" hesitate, like men, to perform a generous action. " Not haughty, not arrogant, not supercilious; " they are full of courtesy, and fond of society; " more liable, in general, to err than man, but, in " general, also more virtuous, and performing more "good actions than he. To a woman, whether " civilized or savage, I never addressed myself in " the language of decency and friendship, without " receiving a decent and friendly answer. With " man it has often been otherwise. In wandering " over the barren plains of inhospitable Denmark, " through honest Sweden, and frozen Lapland, " rude and churlish Finland, unprincipled Russia, " and the wide-spread regions of the wandering " Tartar ; if hungry, dry, cold, wet, or sick, the " women have ever been friendly to me, and uni" formly so : and to add to this virtue, (so worthy " the appellation of benevolence), these actions " have been performed in so free and so kind a " manner, that, if I was dry, I drank the sweetest " draught, and, if hungry, I ate the coarse morsel " with a double relish." But though the native benevolence of the female savage might sometimes soften his distress, yet he seenis often to have endured the extremities of wretchedness. "I am " accustomed to hardships," said he, on the morning of his departure to Africa; "I have known " both hunger and nakedness to the utmost extre" mity of human suffering: I have known what it 
" is to have food given me as charity to a madman; " and I have at times been obliged to shelter my" self under the miseries of that character, to avoid " a heavier calamity: My distresses have been "greater than I have ever owned, or ever will " own, to any man. Such evils are terrible to " bear, but they never yet had power to turn me " from my purpose. If I live, I will faithfully " perform, in its utmost extent, my engagement " to the Society; and if I perish in the attempt, " my honour will still be safe, for death cancels " all bonds."

Mr Lucas, the next person to whom the exploring of the internal regions of Africa was entrusted, had been sent, when a boy, to Cadiz, to be educated as a merchant. On his return, he was captured by a corsair of Sallee, and carried to the court, of Morocco, where he remained three years before he obtained his freedom. After his release, being sent to Gibraltar, he was appointed Vice-consul and Chargé d'affaires to Morocco, where he resided 16 years; and was made Oriental interpreter to the British court, on his return to England. Upon expressing his desire to undertake, with his majesty's permission, any journey in the service of the Association, which his knowledge of the manners, customs, and language of the Arabs, might enable him to accomplish, his 
majesty not only granted this permission, but continued his salary, as Oriental interpreter, during his absence. This gentleman was then appointed to proceed over the desert of Sahara, from Tripoli to Fezzan, a kingdom in some measure dependent on Tripoli, with which the traders of Agadez, Tombuctoo, and other towns of the interior regions, had established a regular intercourse. Whatever intelligence concerning the interior regions he could obtain from the inhabitants of Fezzan, or the traders by whom they were visited, he was to transmit by the way of Tripoli, and afterwards he was to return by the way of Gambia, or the coast of Guinea. These arrangements were settled, and $\mathrm{Mr}$ Lucas having embarked at Marseilles on the 18th of October 1788, arrived on the 25 th of the same month at Tripoli. Tripoli is built in such a low situation, as to be hardly visible at the distance of a mile; but the date trees which spread like a forest behind the town, whence they emerge to cover the hills which bound the southern horizon, render the scene very interesting. Though the capital of an empire, once very powerful, it exhibits, through all its extent, the traces of a rapid decay; for, though it is only four miles in circumference, these limits are too great for its present population. Through the Tripoline ambassador, who had formerly resided in England, he was introduced to the Bashaw, who eagerly inquired af- 
ter the object of his journey to Fezzan, which, he said, no Christian had ever attempted. Mr Lucas replied, that it was for the purpose of examining various Roman antiquities, which he had heard existed in numerous parts of that kingdom, and collecting medicinal plants not found in Europe; the Bey appeared to be satisfied with this answer, and promised him his assistance in his journey. Soon after this, Mr Lucas learned, that certain tribes of tributary Arabs had revolted, and ravaged the frontiers of Tripoli ; and that the Bashaw was levying an army to reduce them, as soon as the grass should be high enough to afford sufficient forage for cattle. While Mr Lucas waited, in order to accompany this army, two Shereefs, or descendants from the Prophet, arrived from Fezzan with slaves; senna, and other articles of merchandize. As their descent from Mahomet secured their persons from violence, and their property from plunder, they did not find it necessary to wait the restoration of peace ; but prepared immediately for their return, and offered to take $\mathrm{Mr}$ Lucas under their protection. Fouwad, one of these, was about 35 years of age, son-in-law to the king; the other was an elderly man, named Imhammed. The Bashaw being informed of this proposal, expressed his approbation of it, and presented Mr Lucas with a handsome mule for his journey, while the Bey, his son, presented him with a tent, and gave him a 
letter of recommendation to the king of Fezzan. But, considering the risk of his being taken by the Arabs, which might oblige him to make a disadvantageous peace, he requested him, immediately afterwards, to defer his journey till the Arabs were reduced. The Shereefs were extremely chagrined at this proposition, as well as $\mathrm{Mr}$ Lucas, since they had written to the king of Fezzan, that they would soon present to him a Christian, who had travelled a journey of many moons from his native land, for no other purpose, but to gratify his wish of visiting him, and seeing his kingdom of Fezzan; and believed that his anger would be so great at this disappointment, that he would probably inflict upon them the greatest indignity which a Shereef can be made to suffer, the heaping dust upon their heads. The remonstrances of the Shereefs, and the representations of an old man of the class of Maraboots, or distinguished saints, induced the Bashaw to comply with Mr Lucas's request, especially as the rebel Arabs had evacuated that part of the country which he was to traverse in his journey. On the 1st of February 1789, therefore, their little caravan left Tripoli, and proceeded towards Fezzan, by the route of Mesurata, which, though not so direct as the ancient passage by the way of Guariano, is yet more safe, as it is not exposed to the impositions of the rapacious tribes, Hooled Ben Soliman, and Benioleed. The heavy 
merchandise belonging to the Shereefs was sent by sea to Mesurata.

After passing Tajara, a wretched village, composed of clay-walled huts, covered partly with terrace, and partly with thatch, they encamped at night upon a sandy eminence, having piled their loads in a circle, lighted their fires, and spread their mats within it. The Shereefs supped, in a familiar manner, with $\mathrm{Mr}$ Lucas in his tent, on dried meat and balls of flower, dressed in steam, and served up in a large wooden dish. After the ceremony of washing, which every man performed, by dipping his hand into the water used by his companions, they took coffee, smoked, and lay down to sleep, in their clothes, upon the bare sand, without any other covering than their Alhaiques or blankets, from the heavy dews of night. The second was spent in travelling among hills of loose and barren sands, where neither man nor beast, wood nor water, appeared, but the sand drifted over them with every gale. On the third day, they emerged from the desert of sand hills, into a hard stony soil, where a few fields vegetated in sullen stillness with meagre grain, while the whitethorn and Spanish broom appeared at a distance, with olive and date trees. On the 4th day, after travelling for some time among rocky hills, variegated with plains of olive and date trees, they reached the ruins of Lebida, a Roman colony, 
where fragments of a temple, and several triumphal arches, still remain, and where the soil of the adjacent district exhibits the most luxuriant vegetation. On the fifth day, as they approached Mesurata, they were alarmed by an account of the depredations of the tribe Hooled Ben Soliman, and soon after fell in with a party of Arabs, whom they imagined to be enemies, and resolved to attack. The Shereef Fouwad, with the horse, led the van, and the foot followed in a confused crowd, like a flock of frighted sheep, dancing, shouting, twirling their muskets over their heads, and jumping round each other like madmen, till they approached within shot of their antagonists, when each man squatted behind a bush, to shelter himself, and take the surer aim. But while they were levelling their muskets, they were recognised by the Arabs for friends; and the caravan proceeding, they arrived in the evening at Mesurata. The governor of Mesurata, who had resided for some time in Italy, received $\mathrm{Mr}$ Lucas with much politeness, but found it impossible to assist him in prosecuting his journey, as camels could not be hired from the rebel tribes of Arabs. After some attempts to procure these, which were always unsuccessful, the Shereef Fouwad retired to Wadan, his native town, and the Shereef Imhammed, to his friends among the mountains, to wait till their journey should be practicable; while $\mathrm{Mr}$ Lucas returned about the 
end of March to Tripoli, and proceeded by Malta and Marseilles to England, where he arrived on July the 26th. During the time, however, that he remained at Mesurata, Mr Lucas, suspecting that his journey would be impracticable, employed himself in procuring from the Shereef Imhammed, an account of Fezzan and of the countries beyond it towards the south, which he had visited as a factor in the slave trade. He roused the Shereef's curiosity, by displaying a map of Africa, as a present which he intended for the king of Fezzan, and requested his assistance to render it more correct. This proposal, which gratified the vanity, as well as the curiosity, of the Shereef, was seconded by the promise of a copy for his own use, and Mr Lucas obtained from him all the information he required. The memorandums which he procured in this manner, were read to the governor of Mesurata, who had formerly travelled to Fezzan, and who confirmed the accuracy of the Shereef's relation. But before the arrival of $\mathrm{Mr}$ Lucas in England, the committee of the Association had obtained a more decisive test of its value, in a narrative given by Ben Alli, a native of Morocco, of his extensive travels as a merchant, in the countries to the south of the Sahara. For, though the Moor's recollection had been impaired by the lapse of 20 years, and his remarks were those of a superficial observer, rather possessed of activity of mind, than 
depth of jadgment; yet the general features of his narrative had such a similarity to the account obtained by $\mathrm{Mr}$ Lucas, as to confirm the authenticity of the principal circumstances.

Fezzan is a small circular territory, situated like an island amid the wilderness of sand. It is an extensive plain, surrounded by an irregular circle of mountains, interrupted on the west, where it communicates with the desert. On the soil, which is chiefly a light sand, no rain ever falls, but the vegetation is luxuriant, from the number of subterraneous springs, which burst through the shallow stratum of sand, and are copiously supplied by the adjacent mountains. Little wheat is raised, but maize and barley are produced in considerable quantities, with pompions, carrots, cucumbers, onions, and garlick. The most common trees are the date, the white thorn, and the talke, which, in size, resembles the small olive, flowers in yellow sprigs, and affords a hard lemon.coloured wood, employed in framing instruments of agriculture. The most sandy soils produce a species of brushwood, resembling the Spanish broom. The camel, the goat, and the hairy broad-tailed sheep, of a light brown colour, are the most frequent domestic animals. The most common wild animals are the ostrich, the antelope, and a small beautiful species of deer, of a clear white colour, streaked with different hues of brownish red, which, as the Fezzanese believe, 
never lies on the ground during the autumnal rains, to avoid sullying its colour. The number of towns and villages is supposed to amount nearly to an hundred. Mourzouk, the capital, lies in N. lat. $27^{\circ} 48^{\prime}$, and E. long. $15^{\circ} 3^{\prime}$, about 280 miles from Mesurata, 1040 from Tombuctoo. Germa, the ancient Garama, now ruined, is situated in N. lat. $27^{\circ} 25^{\prime}$, and E. long. $16^{\circ} 20^{\prime}$. Zuela or Zawila, Tessouwa, Temissa, Kattron, Mendrah, and Tegerhy, are mentioned among its towns. In most of these towns, and dispersed through the open country, numerous ruins of ancient buildings occur, which exhibit the vestiges of former grandeur, in the proportions and durability of their structure, the number and size of the cisterns, and the construction of vaulted caves, similar to those which frequently present themselves among the ridges of Atlas. Fezzan is the Phazania Regio, which Pliny relates was conquered by Corn. Balbus, who took both Allele and Cillaba, in this country, and, at his return to Rome, obtained a triumph. The barren province of Mendrah derives considerable consequence from the quantity of trona, or fassile alkali, which is produced on the surface of its smoking lakes, and is employed in dyeing the Marocco leather. The houses of Fezzan are built of clay, covered with a flat roof, formed of the boughs of trees, over which earth is spread. The Fezzanese, who, by the inhabitants of Tripoli, are reckoned remarkably ugly, 
have less similarity to the Arabs than to the negroes, whom they resemble, not only in their dark swarthy colour, but in the protuberance of the lips, the depression of the nose, and in their short crisped black hair. Their stature is tall, and their form good; but they neither possess strength nor activity. They are represented as a hospitable nation, by persons of the same religion, which is rigid Mahometanism. Their dress is the same with that of the Moors. Though the Fezzanese trade, with the most adventurous spirit, through all Africa, and have some artificers in their towns; yet the principal occupations of the people are agriculture and pasturage. Their diseases are chiefly of the inflammatory and putrid kinds, in curing which they place much greater confidence in charms than in medical applications. The government is purely monarchical, and is only restrained by the influence of opinion, which, among rude nations, constitutes a feeble barrier to injustice. The royal family is descended from that of Taphilet, by whom Fezzan was conquered about 400 years ago. From that period to the middle of the last century, this kingdom maintained its independence, when it was conquered by the Basha of Tripoli, and forced to pay an annual tribute of 50 slaves and $10 \mathrm{lbs}$. of gold dust. The Tripolitan Basha still speaks of his kingdom of Fezzan, but the annual tribute has VOL. I. 
been reduced to an insignificant occasional present. The revenues of the king arise from the duties upon merchandise, and the taxes of the towns, villages, gardens, and date fields. Gold-dust is the medium of commerce. No national forces are maintained in Fezzan; but it is supposed that about 20,000 armed men may be raised on an emergency. Fezzan is separated from the domains of 'Tripoli on the north, by the black barren desert, of Soudah, the soil of which is chiefly composed of a soft stone, which gives rise to no vegetable but the talk-tree and a species of broom.

Gadamis, an oasis of much smaller extent, lies on the N. W. of Fezzan, about N. lat. 32. It is situated 24 journeys to the south of 'Tunis, and 48 to the north of Agadez in Cassina, and is tributary sometimes to Tripoli, but more frequently to Tunis. The soil is dry and barren, producing great quantities of dates, but little corn. The domestic animals are camels and goats. The Gademsis carry on a considerable trade with the negroes by the routes of Fezzan, Taboo, and Tuat, a similar oasis, which lies 20 journeys to the south-west of Gadamis. Morgan relates, that he was told by a Gademsi, at Algiers, that his countrymen spoke the ancient original African language, and that there wàs a remarkable fountain in Gadamis, alternating from hot to cold, like that which is said, by Lucretius and Pliny, to have been situated in the coun- 
try of the Garamantes. Gadamis, like Fezzan, contains many ancient ruins.

On the N. E. of Fezzan lies the desert of Sort, which is prolonged into that of Barca, through which the Cairo caravan, consisting of between 100 and 300 travellers, passes from Mourzouk, which it leaves about the end of October. The route, which occupies 53 days, and about 770 miles, crosses the mountains of Hanibba, Ziltan, and Sibbeel, to Augela, the Egila of Herodotus, and Augila of Ptolemy and Pliny, which lies in N. lat. $29^{\circ}$ 20'. From Augela, after crossing the barren ridges of Gerdobah, the Catabathmus of the ancients, which divided Cyrene from Marmarica, they reach in seven days the narrow sandy plain of Gregabib, extremely fertile in dates. As it is uninhabited, these are gathered by the inhabitants of Derna, the ancient Darnis, situated on the sea-coast, about the distance of 130 miles. Herodotus relates, that the Nasamones were accustomed to leave their cattle on the coast, while they proceeded into the interior, to collect dates on the plains of Agila. On the south of this route lies the great desert of Libya, which is possessed by the wandering tribe of Lebeta, or Levata, the Libyans of the ancients, from whom Africa derived its Grecian name, as they probably occupied the shore of Cyrene, when that country was colonized by the Greeks. Some of the stragglers of this nation seem to have been seen 
by $\mathrm{Mr}$ Park, who mentions the Libey, a wandering tribe, resembling the Gypsies of Europe.

Tibesti, a mountainous district, lies on the S. E. of Fezzan, from which it is separated by a barren desert of 200 miles. Its vales are fertile in corn, and its mountains afford excellent pasturage. Its camels are reckoned the best in Africa. Rain seldom falls in Tibesti, but its want is compensated by innumerable springs. The inhabitants are rude and ferocious, and, secure in the strength of their native mountains, harass their neighbours with frequent hostilities. Though they traded with $\mathrm{Fez}$ zan in senna and camels, they frequently molested the caravans of that country on their journey to Bornou. At last, the king of Fezzan dispatched against them an army of 4000 men, which, after a sharp encounter, reduced them to subjection, the mountaineers being intimidated by the fire arms of the Fezzanese. They engaged to pay an annual tribute of 20 camel-loads of senna, and though, after the departure of the army, they paid little regard to the engagement, they did not again attempt to plunder the caravans. There are some Mahometans in Tibesti.

The extensive empire of Bornou occupies the intermediate space between Nubia and Cassina, Fezzan and Sennaar. The Mahometans of Sennaar number it among the four most powerful monarchies of the world: the other three are Turkey, 
Persia, and Abyssinia. The sovereign of Bornou is more powerful than the emperor of Marocco; and no less than 30 languages are spoken in his dominions. The capital of Bornou is situated in N. lat. $24^{\circ} 32^{\prime}$, and E. long. $22^{\circ} 57^{\prime}, 660 \mathrm{G}$. miles from Mourzouk, and 524 miles west from Dongola on the Nile. 'The powerful Arabian tribes of Booaish and Duhassin occupy the deserts to the north-west of Bornou, collect the dates which grow on the most fertile spots, and sometimes engage in the transportation of merchandize. The general appearance of the country is level and flat. The soil is fertile, though frequently interrupted by stripes of sandy desert, and produces rice, maize, beans, cotton, hemp, and indigo, in abundance. Few dates grow in Bornou; but grapes, apricots, pomegranates, lemons, limes, and melons, abound. Among the native productions of the soil is the Kedeynah, which, in form and height, resembles the olive, and in its leaf the lemon. It produces a nut, the kernel of which is highly esteemed, and an oil is extracted from the shell, which is employed as a substitute for the oil of olives. Domestic animals are the sheep, the goat, the camel, the horse, the buffaloe, and horned cattle. Bees are numerous. The wild animals are the lion, leopard, wolf, fox, wild-dog, civet-cat, elephant, crocodile, hippopotamus, and giraffe, or camelopardales. In the cities of this empire, the houses are built 
with stone and clay, but not disposed in a very regular order. Bornon, the capital, which is larger than Tripoli, is surrounded by a ditch and strong wall, 14 feet in height. The natives are reported to be hospitable and humane. They divide the labour's of the field with the women, and their principal amusements are draughts and chess. The religion of the sovereign and of the predominating tribe is Mahometanism, but the majority of the people adhere to the superstitions of their fathers. The king is elected by three of the principal chiefs, but, as in Cassina, their choice is restricted to the royal family. As soon as they have fixed their choice, they conduct the new sovereign, in silence, to the corpse of his unburied predecessor, and pointing out, in forcible language, the virtues and defects which marked his character, they thus conclude, "You see before you the end of your mor" tal career:-The eternal, which succeeds to it, "will be miserable or happy, in proportion as your " reign shall prove a blessing or a curse to your "people." This practice has some resemblance to the ancient tribunal of the dead in Egypt. The military force of Bornou consists of cavalry, armed with the sabre, the pike, and the.bow. Fire-arms are not entirely unknown, but too difficult to be procured. When the sultan takes the field, he causes a date tree to be placed on-the threshold of one of the gates of his. capital, and ordering his 
horsemen to enter the city one by one, determines the levy to be complete, when the tree is worn through the middle. The articles of commerce exported from Bornou are gold-dust, slaves, horses, salt, and civet. The complexion of the natives of Bornou is black, but their features are different from those of the negroes.

On the north of the Niger, to the south-west of Bornou, lies the extensive and powerful empire of Cassina. On the north it is bounded by the mountains of Eyrè, which separate it from Fezzan, and on the east by Zanfara and Bornou. Cassina, the capital, is situated five journeys to the north of the Niger, in N. lat. $16^{\circ} 20^{\prime}$, and W. long. $11^{\circ} 45^{\prime}$. Cassina is not mentioned by Edrisi, being probably at that period subject to Ghana, which has now, in its turn, become one of its provinces. After the power of Tombuctoo was reduced by the arms of Marocco, it was long considered as the most powerful central empire in Africa; but, at present, though the Sultan of Cassina still enumerates a thousand towns and villages in his extensive domains, he is reckoned much inferior in power to the Emperor of Bornou. The territories of Cassina consist of a large proportion of land of amazing fertility, interspersed with arid wastes, where the rays of the sun, reflected from the sand, glow like an immense furnace with intense and suffocating heat, and sandy heaths, where the odoriferous 
shé plant, which, though superior in fragrance, resembles the wild thyme of Europe, vegetates luxuriantly. The surface of the ground is generally level, though interrupted by naked rocks, and rising in some places into mountains of considerable elevation. The soil is sandy, but intermixed in various proportions with a flat black vegetable mould, insalubrious, in some degree, to animal life. As the rains are more temperate than in some of the more northern districts of Africa, the ground is extremely productive of beans and maize, of which a peculiar species, cultivated in this country, is beautifully variegated with red and white. No salt is produced in Cassina, but the merchants of Agadez, one of its provinces, transport it in great quantities from Domboo in Bornou. Besides Cassina, the principal cities of this country, the names of which are known to Europeans, are Ganatt, Assouda, and Agadez, which are inhabited by Mahometans. Ganatt, which is situated amid barren sandy heaths, lies at the distance of fourteen journeys from Mourzouk in Fezzan, and seventeen from Assouda. The territories of this city are described by Leo as desert and mountainous, though the city was rich and populous, from its convenient position for trade. Its walls and houses were built of chalk. It seems, at that period, to have been the capital of an extensive province, alternately subject to Zegzeg and Cassina. At the 
conquest of these kingdoms, Cano also became subject to Tombuctoo. Assouda is situated eight journeys from Agadez; the intermediate country is beautiful and fertile, presenting numerous herds of cattle grazing between the fields of maize. Agadez, the Agadost of Edrisi, a large populous trading city, lies in $\mathrm{N}$. lat. $20^{\circ} 20^{\prime}$, about $479 \mathrm{G}$. miles from Mourzouk, and 255 from Cassina. The salt caravan of Agadez traverses the vast desert of Bilma, and reaches the salt lakes of Domboo, probably the Chelonides Palus of Ptolemy, after a journey of forty-five days : it consists of $1000 \mathrm{ca}$ mels, maintained for the purpose, and accustomed to this perilous route. The merchants of Cassina export gold-dust, slaves, senna, civet, cotton-cloth, dyed goat-skins, ox and buffaloe hides; and import European cloths, and iron-ware, horses, cowries, and gooroo-nuts. In cloths, the glaring colours are most acceptable, and the inhabitants of Fullan, a district on the west of Cassina, wear clothes which are checked with various colours, like the plaids of the Scotch Highlanders. The majority of the population consists of negroes, who adhere to their ancient superstitions, though the king and many of the chiefs are Mahometans. The government seems to have originated in the predominating influence of a powerful tribe, reducing to subjection those in its vicinity. Hence the tribes which own allegiance to Cassina differ in language, 
character, and manners. The succession to the throne is determined by the election of the chief men, but their choice is confined to the royal family.

The more enterprising of the Fezzan merchants - do not confine their commerce to the countries north of the Niger. They cross that river at a ferry situated 100 miles to the south of Cassina. The Niger here is reported to flow from east to west, and with such rapidity, that no vessel can ascend its stream. The passage is arduous, there being no mode of conveyance but by an ill-constructed raft. On passing the stream, the aspect of nature is entirely changed. To the flat and desolate waste succeed high mountains, narrow valleys, and extensive woods, where, instead of any deficiency of water, miry and inundated roads become the chief obstacle to their progress. It appears, that, after crossing the Niger, they turn westward toward the Gold Coast, and crossing the mountains of Kong, terminate their peregrination at Asiente (Ashantee.) The track thus passed over consists chiefly of a succession of hills, among which are some mountains of stupendous height. The vales are in general well cultivated, and the high grounds covered with numerous herds and flocks; though occasional deserts intervene. These tracks are occupied by a mixed population of $\mathrm{Ma}$ hometans and negroes, who do not, however, regard each other with any degree of religious antipathy. 
The kingdom of Degombah is represented as peculiarly wealthy and civilized, and as distinguished by the art, elsewhere unknown in Africa, of taming the elephant. 'The articles of trade are gold, slaves, goat-skins, buffaloe hides, and a species of nut, called Gooroo.

The difficulty experienced in penetrating from the north into central Africa; began to turn men's attention to the western shore of the continent. The establishment formed at Sierra Leone seemed to offer peculiar facilities for expeditions of discovery on that side. In 1794, Foota Jallo, the extensive and powerful state in the interior of Sierra Leone, was explored in $\mathbf{1 7 9 4}$ by Messrs Watt and Winterbottom, two gentlemen in the service of the Sierra Leone Company, who undertook this expedition upon being informed by some of the Foulahs, that their king was desirous of establishing an intercourse with the colony. They sailed up the Rio Nunez to Kocundy, where they procured interpreters and guides, and experienced various civilities from a mulatto trader in its vicinity. Leaving Kocundy, February 7, 1794, they travelled sixteen days through a country in many places barren, but in others extremely fruitful, abounding remarkably in cattle. After crossing some small rivers, among which the Dunso seems to be a continuation of the Rio Grande, they arrived at Laby. 
Soon after their departure from Rio Nunez, they found that a considerable intercourse subsisted between the interior districts and the higher parts of the river, and often met 500 or 600 Foulahs in a day, carrying on their backs large burdens of rice and ivory to exchange for salt, which, in the interior countries, is the greatest of all luxuries, both on account of its scarcity, and the painful longing that the constant use of vegetable food produces. A child will suck a piece of rock-salt as if it were sugar, and a rich man is described by the phrase he eats salt with his victuals. In the towns, which they met in succession at the distance of six, eight, or ten miles, they were entertained with hospitality, and conducted in safety from one place to another with their baggage. Laby, which is $2 \frac{1}{2}$ miles in circumference, and contains, as they imagined, about 5000 people, lies almost due east from Kocundy, at the distance of 200 miles. Here they inquired concerning Cassina and Tombuctoo. The route to Cassina was represented as extremely dangerous, but a free communication was said to subsist between Laby and Tombuctoo, though a journey of four months distant from each other. The route was described as proceeding through six intervening kingdoms, the names of which were Beliah, Bowria, Manda, Segoo, Susundoo, and Genah, of which the last was said to be the most rich. Segoo is the Sego of Mr Park, the 
capital of Bambarra; Manda is Manding, and Bowriah seems to be Boori, adjacent to Manding; Susundoo is probably Sansanding, while Genah is Genné. At the distance of thirty days journey from Teemboo, the road was said to lie along $a$ great water, across which the eye could not reach, which was sweet and good to the taste. At Laby, the travellers were received with the utmost hospitality by the chief subordinate to the king of the Foulahs, who offered to send one of his sons to be educated in England, and one of the chief Marabouts seemed inclined to follow his example. From Laby, they advanced 72 miles towards the interior, and arrived at Teemboo, the capital of Foota Jallo, which contains 7000 inhabitants. At Teemboo they remained fourteen days, and held various conversations with the king, and with many of the chiefs, through the intervention of their interpreter. The kingdom of Foota Jallo is about 350 miles from east to west, and 200 from north to south. The climate is good, the soil is stony and dry ; about one-third is extremely fertile, and produces rice and maize, which the women cultivate, and the men carry to market, in loads of $1 \frac{1}{2} \mathrm{cwt}$. which rise four feet above their heads. In some of these trading journeys they carry proyisions along with them for eight weeks. Their cattle, horses, mules, asses, sheep, and goats, pasture on the hilly grounds, which contain considerable quan- 
"tities of iron stone. They dig and manufacture a species of iron, which is extremely malleable. The mines are extremely deep, with many galleries or horizontal passages, which are very long, and in some places high and wide, with openings for the admission of air and light. They are wrought by women, who carry victuals along with them when they descend. At Laby and Teemboo, which is about 160 miles distant from Sierra Leone, they manufacture narrow cloths, of which their dress is composed, and work in iron, silver, wood, and leather. Their houses are well built, neat and convenient, placed at a distance from each other, to guard against fire, a precaution which never occurs to the Mandingoes. Among their amusements, horse-racing may be enumerated. The markets and channels of trade are under the regulation of the king, whose power is, in many respects, arbitrary, and his punishments severe. As there are schools in every town, the majority of the people are able to read, and many possess books of law and divinity. The profess the Mahometan religion, have numerous mosques, and are not bigots, though they pray five times in the day. On a sudden emergency, the Foulahs can bring into the field no less than 16,000 cavalry. As they are sur. rounded with twenty-four nations, many of whom are Pagans, their religion affords them a pretext for the acquisition of slaves by war. Some of the 
nations with whom they engage in hostilities, build, for their defence, forts of brick, strongly interlaced with timber. The walls of these forts are six feet in thickness ; they are of a square form, with a tower furnished with stairs at each angle, loopholes dispersed along the walls, the gate concealed, and the whole fortress surrounded with a deep and wide ditch, slightly covered with canes and earth. As the Foulahs have no method of assaulting these forts, they can only reduce them by blockade, which is commonly for the most part unsuccessful, as they contain springs, and are generally stored with provisions. The king's vicegerent, in a conversation with the travellers, openly avowed that the sole object of the wars of Teemboo was to procure slaves, "as they could not obtain European goods " without slaves, nor slaves without making war." He also admitted, that the old men and old women captured in these wars, who were known to be unsaleable, were put to death, by cutting their throats. When the travellers suggested, that, by a trade in ivory, rice, cattle, and the other native produce of the country, they might acquire wealth without going to war for slaves, by which they must certainly offend the God to whom they prayed five times in the day. "The people on whom we make war," replied he, "never pray to God : we do not go " to war with people who serve God Almighty." $\mathrm{He}$ farther stated, that the European factories 
would not trade with guns, powder, and cloth, for any articles except slaves. Similar conversations were held with the king of the Foulahs, and several of the chiefs. The king declared, that he would renounce the slave-trade, if a trade in native produce could be established. One of the chiefs, who defended the religious wars, admitted, that, if the Foulahs could procure European goods without making war, he would believe that God would be offended ; but as this was impossible, God could not be angry, especially when the book desired them to make war on nations that would not serve him. 'The travellers replied, that though there were many good things in the book, yet the devil had certainly inserted that passage, for God was so good and merciful, that he must hate men who destroyed their fellow-creatures; and that the Foulahs ought to instruct those who were more ignorant than themselves. They learned, however, that the wars of Teemboo had ceased, since the wars of Europe had checked the slave-trade. They recommended the use of the plough in cultivation, which had never been heard of in the Foulah country; and the king offered to furnish any European with land, cattle, and men, who should settle among them. From Teemboo, Messrs Watt and Winterbottom returned by a different route, escorted by a strong body of Foulahs, sent by the king. When they arrived at the borders of the Suzee country, the 
Suzees suspected that the Foulahs had come to attack them; but these suspicions were removed at a convention of the chiefs, who determined that the path should be permanently opened through their country, and an intercourse allowed between Teemboo and Sierra Leone. The houses of Sayoua, one of the Suzee towns through which they passed, were even superior to those of Teemboo. The travellers were attended to Sierra Leone by several considerable men, who came as ambassadors from the Foulahs: and other tribes, who, after arranging some commercial plans, returned highly gratified with their reception.

In the kingdoms possessed by the Foulahs; the rural and domestic economy, as well as the manners, religion, and government, are almost the same as in Foota Jallo. Even on the banks of the Gambia, the Foulahs raise the greater part of the corn, and their cattle are better and more numerous than those of the Mandingoes. They are so expert in the breeding and management of cattle, that the Mandingoes generally entrust theirs to their care. They render them tame and tractable by kindness and familiarity; feed them by day in the woods and savannahs, and by night secure them in folds strongly fenced, round which fires are kept burning by the herdsmen, who remain in a hut erected in the middle, to guard them from wild beasts and robbers. They make considerable YOL. I. $\mathrm{x}$ 
quantities of butter; but, like all the other inhabitants of Africa, are entirely ignorant of the art of making cheese. Their aversion to innovation, the heat of the climate, and the scarcity of salt, are circumstances which prevent its introduction. If they discover that a person boils milk, to whom they have sold it, they never sell him any more; from a superstitious idea that it prevents the cow from yielding it. Their horses, which are of the Arabian breed, mixed with the original African, are excellent. The Foulahs are expert and intrepid hunters, and kill lions, tigers, elephants, and other wild beasts, with their muskets and poisoned arrows. In poisoning their arrows, they take the leaves of a shrub, termed koona, which is a species of echites, common in the woods, and, by boiling them in water, procure a black juice, in which they dip a cotton thread, and fasten round the barbs of the arrow.

The districts along the Gambia, and stretching thence into the interior, were soon perceived to be the quarter by which the Niger, and the countries along its banks, could be most effectually explored. In 1791, this country was traversed by the brave but unfortunate Major HougrToN, who first, after the death of Ledyard, and the return of Lucas, attempted to explore Africa, acinrding to the plan of the African Association. 
Having formed an acquaintance with the manners of the Moors, during his residence as British consul at Marocco, and with those of the negroes, while he remained at Goree in the capacity of fort-major, he sailed up the Gambia to Pisania, the residence of the hospitable Dr Laidley. Pisania is a small village in the kingdom of Yani, established by the English on the banks of the Gambia as a trading factory. It lies in N. lat. $13^{\circ}$ 35', and W. long. $13^{\circ} 28^{\prime}$. From Pisania, Major Houghton proceeded to the Mandingo kingdom of Woolli, bounded by Walli on the west, Bondou on the north-east, and on the east by the Simbani wilderness. It is agreeably diversified by plains and rising grounds, extremely fertile, and well cultivated, in the vicinity of the towns. The highest parts of the mountainous ridges exhibit the red iron stone, amidst the stunted shrubs, which hardly detract from the bleakness of the prospect ; cotton, tobacco, and esculent plants, are raised in the valleys; and the intermediate sloping grounds are covered with corn. The Pagans are more numerous than the Mahometans, and retain the ascendancy in the government. At Medina, the capital, the major was received with great hospitality and kindness by the king of Woolli, from whom he received various directions concerning the routes by which it was possible to penetrate into the interior regions. The accounts of these regions, 
which he was able to collect from the slatees, or slave-traders, and travelling. Shereefs and Marabouts, he communicated to Dr Laidley, by whom they were forwarded to the African Association. From these, he appears to have entertained the most sanguine expectations of success. In his letter from Medina, of the 6th of May 1791, he says, "I have obtained the best intelligence of the " places I design visiting, from a Shereef here, " who lives at Tombuctoo, and who luckily knew: " me when I was British consul to the Emperor " of Marocco, in 17\%2. I find, that, in the river "I am going to explore, they have decked vessels " with masts, with which they carry on trade from "Tombuctoo eastward to the centre of Africa. I " mean to embark in one of them from Grenné, in "Bambara, to Tombuctoo." The information concerning the magnitude of the vessels by which the Niger is navigated in the vicinity of Tombuctoo and Houssa, depends upon different authorities, and is as old as the beginning of the last century. De la Brue, as we had formerly occasion to notice, was informed by the Mandingo merchants at Gallam, that; some leagues from Tombuctoo, the Niger was navigated by " masted barks." From various testimonies, Dr Laidley of Pisania was induced to believe, that ships of 100 tons burden frequented Houssa; and Mr Park, before his departure from the Gambia, was informed by a priest who 
had visited Tombuctoo, that the canoes upon the Niger were large, and not made of one tree, but of various planks united, and navigated by white people. From Medina, Major Houghton advanced to Bambouk, and, after crossing the Falemè, at Cacullo, in lat. $13^{\circ} 54^{\prime}$, arrived at Ferbanna. Here he was entertained with extraordinary hospitality by the king of Bambouk, who not only gave him directions for pursuing his route to Tombuctoo, but furnished him with a guide, and with money to defray the expences of the journey. After his departure from Bambouk, the route which he pursued is not accurately known. It appears, how: ever, that having, in opposition to the opinion of his friends in England, and even to that which he himself had stated, encumbered himself with an assortment of bale goods, consisting of linen, scarlet-cloth; cutlery ware, beads, and ambers; the powerful attractions which these presented to the rapacity of the natives, involved him in perpetual contests. After surmounting many difficulties, he took a northern direction, and éndeavoured to penetrate through Ludamar. From Simbing, the frontier village of this state, which is situated in a narrow pass between two rocky hills, and encompassed with a high wall, he wrote with a pencil his last letter to Dr Laidley, when he was deserted by his negro servants, who refused to follow him into the Moorish territory. This letter was dated 
September 1, 1791, and expressed in the following terms: "Major Houghton's compliments to "Dr Laidley, is in good health, on his way to " Tombuctoo, robbed of all his goods by Fenda "Bucar's son." At Jarra, for a musket and some tobacco, he engaged certain Moorish merchants, who were going to purchase salt in the desert, to convey him to Tisheet, which lies near the saltpits, ten days journey to the north of Jarra. Whether he had been deceived concerning his route, or insidiously decoyed into the desert, it is impossible to determine; but, at the end of two days, suspecting the perfidy of his companions, he resolved to return to Jarra, and, upon refusing to advance, was deserted and plundered by the Moors. Major Houghton returned on foot through the desert, solitary, and perishing with hunger. He had wanted food for some days when he reached Jarra; a watering-place belonging to the Moors, where he was either murdered or suffered to perish, as the Moors refused to supply him with meat. His body was dragged into the wilderness, and left to waste under a tree, in a spot which was pointed out to Mr Park at Jarra. The traders on the Gambia reported that he had been murdered at the instigation of the king of Bambara; but this was afterwards contradicted, and he was asserted to have died of a dysentery. Dr Laidley attempted to recover his books or papers, by offering re- 
wards to the native traders, but without success. Thus was the Association a second time deprived of the exertions of a man, whose courage and abilities afforded the fairest presages of success, while the shocking circumstances of his death could not fail to mingle the emotions of regret with the feelings of disappointment. 


\section{CHAPTER VI.}

'MR PARK'S FIRST JOURNEY.

Arrival of Mr Park.-Pisania-Yani-Medina-BondouKajaga-Kasson-Kaarta.-Account of the Lotus.-War between Kaarta and Bambara.-Travels and detention in Ludamar.-Escape through the Wilderness to Bambara.Travels in Bambara to Silla, and return along the Niger. - Travels in Manding, and hospitable reception at Kamaliah.-Travels in Jallonkadoo.-Konkodoo, Satadoo, and Dentila.-Account of Foota-Torra.-Return to Pisania.

Though the circumstances attendant on the fate of Major Houghton remained in obscurity, the intelligence of his death was soon fully confirmed. The Association, however, were not discouraged, but sought immediately for another to supply his place. They were so fortunate as to engage a gentleman of the most peculiar and splendid qualifications. Mr Mungo Park, a native of Scotland, born near Selkirk, who had received a medical education at Edinburgh, and was lately returned from a voyage to the East Indies, inflamed with an ardent desire of exploring these unknown regions, was proposed, at his own desire, to the Association, by the President of the Royal Society, and, after satisfying the committee with respect to his skill in astronomy, geography, 
and natural history, sailed from Portsmouth on May 22, 1795, and, on the 21st of June, arrived at Jillifree, on the northern bank of the Gambia. Jillifree, in N. lat. $13^{\circ} 16^{\prime}$, and W. long. $16^{\circ} 7^{\prime}$, is situated in the fertile kingdom of Barra, the inhabitants of which trade up the Gambia in canoes, as high as Baraconda, with salt, which they exchange for maize, cotton-cloth, ivory, and golddust. The number of persons employed in this trade, renders the king of Barra the most powerful chief on the Gambia, and enables him to impose exorbitant duties on European traders, who visit the river. After touching at Vintain, they sailed up the Gambia to Jonkakonda, a trading town within sixteen miles of Pisania, where $\mathrm{Mr}$ Park was expected by Dr Laidley, who invited him to reside at his own house, till an opportunity occurred of prosecuting his journey to the interior. During his residence at Pisania, the exertions of Mr Park were directed to the acquisition of the Mandingo language, the examination of the natural productions of the country, and the procuring information concerning the interior regions from the free black traders, who all appeared averse to his proposed journey; but these occupations were, for some time, interrupted by the country fever, or seasoning, which he caught by exposing himself to the night dew. Yani, and the adjacent Mandingo districts, present an immense level surface, where 
the absence of picturesque beauty is compensated by the fertility of the soil. Besides rice, millet, maize, and esculent vegetables, the natives cultivate indigo and cotton in the vicinity of their towns and villages. Their domestic animals are almost the same as in Europe; the ass is employed in carrying burdens; but the plough is unknown, and the substitution of animal for human labour unpractised in agriculture. The most common wild animals are the elephant, panther, hyæna, and jackal. The negroes of the Gambia have no idea of taming the elephant, and, when the practice is mentioned, term it a white man's lie. The shrill bark of the jackal, and the deep howl of the hyæna, mingling with the incessant croaking of frogs, and the tremendous peals of midnight thunder,-form no pleasant symphony. The Gambia is deep and muddy, and its banks are covered with impenetrable thickets of mangroves. The stream contains sharks, crocodiles, and river-horses, (an animal which may be more properly denominated the river-elephant,) in immense numbers, with various kinds of excellent fish. The negroes live chiefly on vegetable food ; they reduce their corn to meal in a mortar, and most commonly use it in the form of kouskous, a species of pudding dressed in the steam of broth made with animal food. The shea-toulou, a tree, which, in food, is substituted for butter, and in domestic purposes for oil, is obtained in great quan. 
tities from the interior districts. The trade of the negroes is conducted by barter; and, in order to adjust the value of their different articles of commerce, they appeal to a nominal standard, which, from Senegal to Cape Mount, is termed a bar; from Cape Mount to Cape Palmas, a piece; from Cape Palmas to Whidah, an ackey; from Whidah to Benin, a paren; and from Benin to Gabon, $a$ copper. These denominations originated from the particular species of merchandize for which the negroes shewed the greatest avidity, when Europeans began to trade on these coasts. On the Gambia, that quantity of any particular species of goods, which is valued at a bar of iron, is denominated a bar of that commodity.

On 2d December 1795, at the commencement of the dry season, Mr Park departed from Pisania, without waiting for the coffle, a caravan of slatees, or slave-traders, of whose jealousy he was appreherisive. He advanced into the kingdom of Walli, attended by two negro servants, and accompanied by two slatees of the Serawoolli nation, and two free Mahometan negroes, of whom one was going to Bambara, and the other, a blacksmith, who had been employed by Dr Laidley, was returning to Kassan, his native country. One of his servants, named Johnson, who had been in England, and spoke the English and Mandingo languages, was hired at the rate of fifteen bars a month, five of 
which were to be paid to his wife, during his ab. sence, and the remainder to himself. The other was a boy named Demba, the slave of Dr Laidley, who, on the condition of fidelity, had promised to emancipate him at his return. His baggage consisted chiefly of a pocket sextant, a magnetic compass, a thermometer, an umbrella, two fowlingpieces, two pair of pistols, and a few changes of linen and clothes. In the day they continued their journey, and in the evening were entertained by ludicrous tales, resembling those of the Arabians, which the Mandingoes related. On December 5, they arrived at Medina, the capital of Woolli, containing about 1000 houses, surrounded with a high wall of clay, and an exterior fence of pointed stakes and prickly bushes. Here Mr Park was introduced to the venerable chief who had received Major Houghton with so great hospitality. He found him seated upon a mat at the door of his hut; and, upon desiring leave to pass through his territories, was answered, that he should be furnished with a guide next day, and assured that the king himself would pray for his safety, but entreated him to desist from a journey of such imminent danger, which had already proved fatal to Major Houghton. In return for this kindness, one of MrPark's attendants began immediately to sing an Arabic song, in which the king and his people joined as chorus. After receiving the guide, he departed from Medina, and, 
on the 8th, arrived at Kolor, in N. lat. $13^{\circ} 49^{\prime}$, near the entrance of which he saw the dress of Mumbo-Jumbo hanging upon a tree. Passing through Tambacunda and Kooniakary, he reached Koojar, the frontier town of Woolli, on the 11th, and hired three elephant hunters to accompany him as guides through the wilderness, which separates that kingdom from Bondou. In the evening, he was invited to be a spectator of a wrestling match, at the Bentang. The contest was regulated by the music of a drum; the combatants were only clothed in a short pair of drawers, and anointed with oil or shea-butter; they approached bending low, parrying with their hands, and attempting to catch at the knees. This method of wrestling is similar to that which is practised in many places of Scotland and Wales, and seems to have been used in Syria at a very ancient period, as appears from a circumstance narrated in the history of Jacob. Next morning, one of his guides, who had received part of his wages in advance, had absconded, and, in order to prevent the other two from following his example, Mr Park immediately departed, and entered the wilderness. His attendants having prepared a saphie, or charm, to avert misfortune, advanced with courage, and soon arrived at a large tree, decorated with innumerable scraps of cloth, as custom had directed every traveller, who desired a fortunate jour. 
ney, to hang up something on its branches. This practice, originally intended to mark a wateringplace, had degenerated to a blind superstition; and to encourage his attendants, Mr Park followed the example of the negroes. On the 13 th he arrived at Tallika, the frontier town of Bondou, and traversed a fertile champaign country, till he reached Koorkarany, in N. lat. $13^{\circ} 53^{\prime}$, being only interrupted by a quarrel between two of his attendants, which he terminated by threatening to shoot the person who had drawn his cutlass, if he attempted again to molest any of the company. At Koorkarany, the Marabout shewed him various Arahic MSS. and, among the rest, the $\mathrm{Al}$ Sharra. From Koorkarany they proceeded through an open cultivated country, till they reached the banks of the Falemé, covered with large fields of corn; the mimosa grew on the stony heights, and whinstone and quartz were often observed. Some wells which they passed were dug with great ingenuity, to the depth of 28 th fathoms. The villagers on the Falemé were skilful fishers. They prepare their fish by pounding them in a mortar, while fresh from the water, and drying them in the sun, into large loaves, which, in eating, they dissolve in boiling water, and mix with their kouskous. The black loaves, prepared in this inanner, form an article of commerce in the Moorish districts, where fish is hardly known. The 
women were often rude and troublesome by their solicitations for amber and beads. On the 21st they arrived at Fatteconda, the capital of Bondou, and, according to custom, presenting themselves at the Bentang, were invited to lodge at the house of a slatee. Mr Park was immediately conducted to a private conference with Almami the king, who had caused Major Houghton to be plundered. He was surprised that Mr Park neither wished to purchase slaves nor gold, and desired him to return and receive provisions in the evening. Dreading this interview, Mr Park carried with him his umbrella, and some other articles, as a present to his majesty, and put on his new blue coat, as the safest method to preserve it. Being conducted to the palace, a kind of citadel, subdivided into courts, the various passages of which were guarded by centinels with muskets, he was introduced in form to the king, who understood the value of the presents much better than the narration of the traveller; as the design of travelling for curiesity, merely to view the country and its inhabitants, was still more incomprehensible than the mechanism of the umbrella. But as he was going to depart, his majesty desired him to stop a little, and immediately favoured him with a specimen of African elequence, equally unsatisfactory to the traveller. It commenced with a panegyric on the whites, their im- 
mense wealth, and extensive benevolence: The body of the narration consisted of an ingenious eulogium on Mr Park's blue coat, not omitting the yellow buttons with which it was decorated, while the conclusion contained an eloquent address to the owner, to persuade him to present it to his majesty, urging, that he would wear it on all public occasions, and inform every one that saw it of the donor's generosity. These arguments, with still more powerful motives, which his majesty did not urge, induced Mr Park to comply with this request, and quietly stripping off his coat, he laid it at the feet of the king. In consideration of this and the other presents, he was presented with five drachms of gold, and his baggage was exempted from examination. Next day the king desired him to visit his women, and upon his assenting, he was conducted into the seraglio. Here he was rallied by the African beauties, upon the whiteness of his skin, and the prominence of his nose, which, they alleged, were both artificial. The first, these philosophical ladies attributed to his having been bathed in milk when young, while they fancied that the nose had been elevated by pinching it from time to time, till it acquired its actual form. In return for these compliments on his features and complexion, Mr Park, with great gallantry, praised " the glossy " jet of their skins, and the lovely depression of 
"their noses ;" but they told him, that honeymouth was not esteemed in Bondou. He remarks, however, that they were probably not so insensible to flattery as they affected; for, after his departure, they presented him with fish and a jar of honey. Bondou, like Woolli, is covered with wood, but the land is more elevated and fertile. From its central situation, between the Senegal and Gambia, it is much frequented by the Mandingo and Serawoolli traders. As the duties are heavy, the revenues of the king are considerable, and, consequently, his authority firmly established, and his power formidable to his neighbours. On the 23d, they departed from Fatteconda, and, while the moon shone bright, and the deep silence of the woods was only interrupted by the howling of the wolves and hyænas, that glided like shadows through the thickets, they walked without articulating a word louder than a whisper, traversed the wilderness which divides Bondou from Kajaaga, and on the 24th arrived at Joag, the frontier town of that kingdom. Joag is situated 2417 miles east of Pisania, in N. lat. $14^{\circ} 25^{\prime}$, and W. long. $9^{\circ} 12^{\prime}$. It contains about 2000 inhabitants, and is surrounded by a high wall, with port holes for musketry. The habitation of every individual is also surrounded with a distinct wall in the manner of the insula of the ancients. They took up their residence in the house of the judge, or Dooty, who VOL. I. 
is termed the Alkaid on the coast, and were invited to attend the public dances in the evening. But, during the night, a party of horse arrived from the king of Kajaaga, and being joined by others in the morning, surrounded Mr Park with their muskets in their hands, and informed him, that, having entered the country without paying the duties, his people, cattle, and baggage, were forfeited, and that they were ordered to conduct him immediately to Maana, the residence of the king. As resistance was impossible, he affected to comply with this peremptory order; but, after consulting his landlord, who represented in strong terms the avarice of the Serawoolli prince, he resolved, if possible, to conciliate the messengers, which he effected with the loss of half his property. During the remainder of the day, he and his attendants were obliged to fast, as he was plundered of his money, and durst not produce his remaining effects, lest they should attract the avarice of the king. In this situation, while he was sitting on the bentang, chewing straws, he was accosted by an aged female slave, who inquired if he had got his dinner. As he imagined she only mocked him, he did not reply, but his boy answered, that the king's people had robbed him of his money; when the benevolent slave took a basket from her head, presented him with a few handfuls of earthnuts, and departed before he had time to thank 
her. Immediately afterwards, he was visited by Demba Sego, nephew of the king of Kasson, who was returning from the king of Kajaaga, with whom he had in vain attempted to adjust the disputes that had occurred between that kingdom and Kasson. Upon learning the situation of Mr Park, Demba Sego offered to conduct him to the Mandingo kingdom of Kasson. Accepting. this offer, he departed with his attendants from Joag, on the 27th of December; and, passing by the towns of Gungadi and Samee, they reached Kazee, a large village, where they crossed the Senegal, and entered the kingdom of Kasson. The journey was marked by nothing remarkable, except the sacrifice of a white chicken, which was offered by Johnson, the interpreter, to the spirits of the woods, described as a powerful race of white beings, with long flowing hair. No sooner had they entered Kasson, than Demba Sego suggested the propriety of rewarding his services by a handsome present. At this unexpected proposition, Mr Park began to suspect that he had not altered his situation by crossing the Senegal ; but, as complaints would not have availed, he affected to comply with alacrity ; and, advancing on the journey, on December 29th, arrived at Teesee. Teesee is a large unwalled town, fortified with a kind of citadel, inhabited by Mandingoes. The inhabitants have one singular eustom, that no woman is allowed to 
eat an egg. As his friend, Demba, in order to give himself an air of importance, had borrowed his horse, bridle, and saddle, while he went to negociate with the Moors of Gedumah, Mr Park was forced to remain till his return; during which time, an embassy from Almami Abdulkader, king of Foota Torra, arrived at Teesee, and announced to the commandant Tiggity Sego, the father of Demba, that, unless the people of Kasson should enbrace the Mahometan religion, and demonstrate their conversion by saying eleven public prayers, the king of Foota 'Torra would, in the approaching war, unite his arms with those of Kajaaga. Upon mature deliberation, the inhabitants of Teesee, considering that much less injury could result from the repetition of public prayers than from the armies of Foota Torra, resolved to comply with the condition, which was accordingly received as a sufficient proof of their conversion. At the return of Demba, $\mathrm{Mr}$ Park resolved to proceed immediately to Kooniakary, the capital ; but, before he was allowed to depart from Teesee, he was plundered of half his remaining goods, by his obliging friend, under the double pretext of duties and presents. Leaving Teesee, on the morning of January 10th, after crossing Krieko, a branch of the Senegal, near a large town named Madina, they arrived, on the second day, at Jumbo, the native town of the blacksmith, whose brother came out to meet him, accom- 
panied by a singing man, and bringing a horse to him, that he might enter his native town like a person of consequence. As soon as they approached the town, they were joined by a number of the inhabitants, shouting, jumping, and singing, and the minstrel began a song in praise of the blacksmith, extolling his courage, and exhorting his friends to dress abundance of victuals for him. His relations testified the most extravagant joy at his return, and his aged blind mother was led out, leaning on a staff, to congratulate her son, who stroked his hands, arms, and face, and seemed greatly delighted. During this tumult of joy, when the attention of every one was so much absorbed, that none of them observed the white stranger, $\mathrm{Mr}$ Park seated himself beside one of the huts; but when the negro proceeded to detail his history, from the period of his leaving Kasson, and, after repeatedly mentioning the kindness of the white traveller, pointing to the place, and exclaimed, "See him sitting there,"-their joy was converted into amazement, the eyes of all were turned upon the stranger, and none could comprehend how he had arrived without being perceived. The women and children, however, could not conceal their apprehensions at his appearance, nor be reconciled to it for some time, though the blacksmith declared him to be quite inoffensive. The gratitude of this negro was so great, that he re. 
fused to leave $\mathrm{Mr}$ Park while he remained at Kooniakary. On his way to Kooniakary, he visited Soola, where Salim Daucari, a respectable slatee, on whom he had a letter of credit from Dr Laidley, was accustomed to reside. Here he was received with the utmost attention; but, in a few hours, a messenger arrived from the king of Kasson, to demand the reason of this delay. Mr Park proceeded immediately to Kooniakary, and, next day, in the presence of an immense concourse of people, had an audience of his majesty, by whom he was very favourably received, and who appeared to be satisfied with the account of his journey. The king of Kasson informed him of the approaching war, in which all the neighbouring countries would be necessarily involved, but agreed to allow him a guide into Kaarta. Mr Park desired a guide to conduct him into Fooladoo; but the king replied, that he was bound, by an agreement with the king of Kaarta, to send all merchants and travellers into his territories, and therefore could not, in consistence with justice, allow him a guide by any other route. During his residence at Soolo, for a few days, till the messengers returned who had been sent to ascertain the state of the adjacent country, $\mathrm{Mr}$ Park was subjected to new impositions, from a rumour arising that he had received a great quantity of gold from Salim Daucari. The kingdom of Kasson is a beautiful level country, the population 
and culture of which exceeded those of any region which our traveller had as yet visited. Kooniakary, the capital, lies in N. lat. $14^{\circ} 34^{\prime}$, about $59 \frac{1}{2}$ geographical miles to the east of Joag. From Soolo Mr Park proceeded along the populous banks of the Krieko, by Kimo, Feesurah, and Karancalla, to Kemmoo, the capital of Kaarta, where he arrived on February 12th. On the journey, having separated a little way from his companions, he fell in with two negro horsemen, who were struck with consternation at the singularity of his appearance, and galloped off muttering prayers with looks of horror. Meeting his attendants, they related that they had seen a tremendous spirit, arrayed in flowing robes, while a chill blast came rushing upon them like cold water from the sky. At Kemmoo he met with the most hospitable reception from Daisy Koorabarri, 'king of. Kaarta, whose character was not tarnished by any of those acts of rapacity which had marked the conduct of the other African princes. As all intercourse between Kaarta and Bambara had been interrupted, and a residence in Kaarta was equally dangerous to Mr Park, and disagreeable to Daisy the king, who dreaded the imputation of murdering a white man, he chose the only remaining route to Bambara, through the kingdom of Ludamar, equally hazardous and circuitous, where Major Houghton had already perished. On February 13 th he de. 
parted from Kemmoo, and proceeded with an escort to Funingkedy, where he had an opportunity of observing the hardiness of the Moors, five of whom, armed with muskets, drove off a number of cattle belonging to the inhabitants, and passed within pistol-shot of 500 of the townsmen, collected under the walls, who scarcely made a shew of resistance. One of the herdsmen; whose leg was fractured by a shot, died in the hands of the Bushreens, who attempted to smuggle him into Paradise, by teaching him, before his exit, to pronounce: the Mahometan confession of faith, There is but one God, and Mahomet is his prophet. His disconsolate mother only exclaimed, "He never told " a lie;" but the spectators formed a dismal chorus of screams and groans. Mr Park was regarded as a cannibal, for proposing the operation of amputation.

On the road between Kemmoo and Funingkedy, Mr Park first observed the negroes gathering tomberongs, or the berries of the Rhamnus lotus. The lotus is common in all the negro kingdoms, and is found on the Gambia, but it is in the sandy soil of Kaarta, Ludamar, and the northern districts of Bambara, that it is most abundant. There the natives collect the small farinaceous berries, which are of a yellow colour and delicious taste, and, by drying them in the sun, pounding them in a mortar, and forming them into a paste with water, com- 
pose a sort of bread, which resembles the sweetest gingerbread in colour and flavour. The water, sweetened with the juice of the lotus berry, forms a pleasant gruel, which is the common breakfast in many parts of Ludamar. The lotus shrub is found at Tunis, and seems evidently to be the plant which nourished the Libyan Lotophagi of Homer and Pliny, and with which, according to Pliny, armies were sometimes supported.

From Funingkedy, Mr Park proceeded by Simbing to Jarra, a large town situated at the foot of some rocky hills, in N. lat. $15^{\circ} 5^{\prime}$, and was attended on his route by numerous fugitive Kaartans, who fled from the arms of Bambara. Notwithstanding the uniformity of the negro wars, that of Kaarta derives considerable interest from the amicable character of the chief of that country. It originated in a contest concerning the restitution of some cattle that had been stolen by the Moors from Bambara, and sold to the chief of the Kaar. tan village. Mansong, king of Bambara, who had been. long jealous of the prosperity of Kaarta, availing himself of this pretext, sent a message to king Daisy, desiring him to direct his slaves to, sweep the houses, and have every thing prepared, as the king of Bambara, with 9000 men, would visit Kemmoo in the dry season. This insulting message was accompanied with a hierogly. phical present. It consisted of a pair of iron 
sandals, and the explanation was supplied by the bearer, " that, until the king of Kaarta had worn " out these in his flight, he should not be secure " from the arrows of Bambara." Rude nations generally supply the deficiency of their language by the energy of their gestures, and the slowness of their capacity by the vivacity of their images and significant actions. The hieroglyphical message of the Scythian ambassador, who, without speaking a word, presented to Darius a bird, a frog, a mouse, and five arrows, is well known. Herodotus mentions that the same Darius sent notice to the Ioni- an Greeks, that, if they continued their depredations in Asia, lie would treat them as pines, or exterminate them, for no shoots rise from the pine when it is cut down. The chief of the Narraghanset Indians, to express his mortal enmity to the first settlers of New England, sent them a rattlesnake's skin stuffed full of arrows, to which the English replied very intelligibly, by returning the same skin stuffed with powder and bullets. Upon receiving a similar message from the king of Bambara, the Kaartan prince, after consulting with his chief men, returned a similar defiance, and, immediately issuing proclamations, called upon his friends to join him, permitting all who were unarmed, or afraid of the war, to retire into any of the adjoining states, whence they should always be welcome to return, if they observed a rigid neutra- 
lity; but, if they engaged in hostilities against their native country, he declared, that " they had " broken the keys of their huts, and could never "again enter the door." Though the proclamation was generally applauded, various powerful tribes, particularly those of Jower and Kakaroo, retired from Kaarta into Kasson and Ludamar, by which means Daisy's army was reduced to 4000 effective men. At the approach of Mansong to Kemmoo, Daisy retreated to Joko, and afterwards to Gedingooma, a strong town, surrounded with high walls of stone, situated in a narrow pass between two hills, with only two gates, the one facing Kaarta, and the other Jaffnoo. At Joko, however, his sons refused to accompany his flight, "lest the singing men should say, that Daisy and " his family had fled from Joko without firing a "gun." They were therefore left vith a party of horse to defend Joko, but, after various skirmishes, were defeated, and one of them taken prisoner, upon which the others retired to Gedingooma. When Mansong saw that Daisy would not hazard a battle, he ravaged Kaarta with fire and sword; but, being unable to make any impression on Gedingooma, after remaining about two montlis in its vicinity, he marched to attack Ali, the Moorish king of Ludamar, who refused to furnish him with the auxiliaries he had promised; and, upon the retreat of the Moors, retired to 
Sego. The king of Kasson dying at this period, the succession was disputed by his two sons; the unsuccessful candidate retired to Gedingooma ; and as Daisy, who had lived in friendship with both the brothers, refused to deliver him up, though he did not interfere in the contest, the king of Kasson joined some disaffected Kaartans in a predatory excursion into Kaarta. Daisy retaliated this attack, by surprising three large villages of Kasson, and putting every effective man to the sword, and, among the rest, many of his own traitorous subjects. Upon this, the Kaartan tribes, by whom he had been deserted, commenced hostilities against their former prince, but were obliged to retreat at the approach of Daisy, when the war was terminated by the rainy season.

Jarra, often pronounced Yarra and Yarba, where Mr Park had now arrived, is a large town, the houses of which are built of stone, intermixed with clay instead of mortar, the majority of the inhabitants of which are negroes. Here he resided fourteen days in the house of a Gambia slatee, (upon whom he had an order from Dr Laidley for a debt,) till a messenger returned from Ali the Moorish prince, to whom he had been sent to solicit permission to travel through his country. On the 26th of February, one of Ali's slaves arrived to conduct him to Goomba; and as all his attendants, except his faithful boy Demba, refus- 
ed to advance into the Moorish country, he delivered a duplicate of his papers to Johnson, to convey them to the Gambia. Here he left his supernumerary clothes with Daman Jumma, the slatee, and here he was plundered of his sextant, which accident terminated his observations of latitude, and caused the parallels of his remaining geographical stations to be left undetermined. From Jarra he departed, on the 27 th of February; and advanced through a sandy country, by Troomgoomba and Quiza, to Deena, a large town built of stone and clay, where the Moors were more numerous in proportion to the negroes than at Jarra. These ferocious fanatics insulted $\mathrm{Mr}$ Park in the grossest manner; but, finding it impossible to irritate him so far as to afford them a pretext for seizing his baggage, they determined to plunder him, because he was a Christian, and the pretended protection of Ali did not secure him from their rapacity. From Deena, he proceeded over a sandy country, covered with Asclepias gigantica, to Sampaka, a large town which formerly belonged to Bambara, and had often resisted the attacks of the Moors, but, at the termination of the last war between the Moors and Bambarans, had been resigned to the king of Ludamar, with all the country as far as Goomba. There he lodged in the house of a negro, who manufactured gunpowder from nitre, collected from the reservoirs of water frequented 
by the cattle, and sulphur supplied by the Moors, who obtain it from the Mediterranean. The ingredients are pounded in a wooden mortar, the grains are unequal, and the strength of the gunpowder very inferior to that of Europe. From Sampaka he proceeded to Dalli, within two 'days' journey of Goomba, where he arrived on the 5 th of March ; and, remaining in a village in its vicinity, till he should be joined by some of the inhabitants who intended to accompany him to Goomba, he was seized, on the 7th, by a party of Moors, who were ordered by Ali to convey him to Benowm, as his favourite wife Fatima was desirous of seeing the Christian. By the Moors he was conducted back to Deena, where he saw one of Ali's sons, who immediately handed him a double barrelled gun, and commanded him to repair one of the locks, and dye the stock of a blue colour. Mr Park found it extremely difficult to persuade him that a white might be ignorant of this art. On March 12th, they arrived at Benowm, which exhibited a great number of tents scattered irregularly over a large extent of ground, and divided by herds of camels, cattle, and goats. Here he remained till the 30th of April, and was treated with the utmost insolence and brutality by the Moors, who shut him up in a hut in which a wild hog was tied, which the boys constantly irritated by beating, while the men and women regularly assembled to 
teaze the Christian. Their curiosity was almost as disagreeable as their insolence, as they examined his clothes, searched his pockets, wondered at the whiteness of his skin, counted his toes and fingers, and forced him to continue dressing and undressing himself, buttoning and unbuttoning his clothes, from noon to night, while he was perishing with hunger and thirst. The curiosity of the females of Ludamar formed no exception to the common opinions entertained on that subject. As the cultivation of their minds could not fail to inspire them with deep disgust at that species of prostitution which is sanctioned by the Moorish customs, they are entirely unacquainted with refinement and delicacy; and when their natural timidity is emboldened by numbers, they are unrestrained by modesty or decorum. A party of the Moorish females, who visited Mr Park, were very curious to examine whether the rite of circumcision extended to the Christians. Mr Park treated the matter in a jocular manner, and assured one of the most handsome, that he would satisfy her curiosity, if the others would retire; when they all departed, much delighted with the jest. While he remained at Benowm, he had an opportunity of seeing a Moorish wedding; it was not celebrated with the same festivity of song and dance as the negro weddings; one woman beat a drum, and the others made a kind of whistling noise, or frog-music with 
their mouths. When he had retired to his hut, and was sitting almost asleep, an old woman entered, and told him she had brought him a present from the bride, and immediately discharged in his face the contents of a wooden bowl which she carried in her hand. As Mr Park, who perceived that it was the same species of holy water with which the priest sprinkles a new married couple among the Hottentots, did not exhibit much gratitude for the favour, the old lady informed him seriously, that this nuptial benediction of the bride was received by the unmarried Moors as the highest mark of esteem.

Before Johnson had time to depart from Jarra, he was also seized by the Moors, and conveyed to Benowm, with all the effects of Mr Park that had been left in the house of Daman Jumma, except the papers which had been committed by Johnson to the care of one of the wives of Daman. These, with $\mathrm{Mr}$ Park's watch, his gold, amber, and pocket. compass, were deposited in the tent of Ali,-whose superstitious fears were soon excited by the compass, and he inquired why that small piece of iron (the needle) always pointed to the great desert. As a scientific explanation would have been unintelligible, and affected ignorance would have excited suspicion, Mr Park told him that it pointed to his mother, who resided beyond the great desert, and would conduct him to her if she was alive, 
and, when she was dead, direct him to her grave. Upon this explanation, Ali, who began to regard it with still greater amazement, turned it repeatedly round, and, as it still pointed to the desert, returned it with great caution, as too dangerous an instrument to keep in his possession. As the Moors, though extremely indolent, are very rigid masters, $\mathrm{Mr}$ Park's two negro servants were employed in collecting withered grass for the king's horses, and, after many consultations, he was himself installed in the office of barber to his barbarian majesty, but acquitted himself so ill at his first exhibition, in shaving the head of the young prince, that he was immediately deposed. Various consultations were held, concerning his future destination : some advised that he should be put to death, others that he should lose his right hand, while the king's brother proposed to put out his eyes, which, he said, resembled those of a cat, to which measure all the Bushreens agreed; but Ali deferred the execution of the sentence, till Fatima, the queen, came from the north. In the mean time, he was ordered not to go without the camp; and, on walking to some shady trees, at a little distance, to escape the insults with which he was continually harassed, he was pursued by a party of horsemen, one of whom snapped a pistol twice at him, with the utmost indifference. Mr Park's nankeen breeches appeared VOL. I. 
to the Moors not only inelegant but indecent; and Ali caused him to wrap himself up in his cloak, when he carried him to visit his women. These ladies were very inquisitive, and examined his hair and skin, but knit their brows, and shuddered at the whiteness of his colour. On such occasions, the Moors conducted him in a kind of procession, galloping round him as if they had been baiting a wild beast, twirling their muskets round their heads, and exhibiting feats of activity and horsemanship. To relieve the irksomeness of time, he began to learn the Arabic characters, and, by desiring the most insolent of the Moors, either to write on the sand, or decypher the characters which he had formed, he discovered a method of diverting their malicious propensities, by addressing their vanity, and pride of superior accomplishments.

During the time that he remained at Benowm, he held various conversations with two Mahometan travellers, who traded in salt; one of whom resided in Walet, and had visited Tombuctoo and Houssa. He described Walet, the capital of Beeroo, as larger than Tombuctoo, though not so much frequented by strangers, on account of its distance from the Niger, and its trade being chiefly confined to salt. He related, that Walet was distant ten days' journey from Benowm, the route passing through a barren country, where there 
were no remarkable towns. From Walet to Tombuctoo, he reported to be eleven days' 'journey, which was usually performed on bullocks. Houssa was the largest town he had ever seen. When Mr Park inquired so particularly concerning the distance between Walet and Tombuctoo, he asked if he intended to travel in that direction : being answered in the affirmative, he said it would not do, and added, that Christians were regarded there as children of the devil, and enemies of the prophet. He said that many Jews resided at Tombuctoo, who spoke Arabic, and used the Moorish prayers. The other traveller, a native of Marocco, had resided some months in Gibraltar. He related, that the route from Marocco to Benowm occupied fifty days, having the following intervals between the stations; from Marocco to Swera, three days; to Agadier, three; to Jiniken, ten ; to Wal de Non, four ; to Lakeneig, five ; to Zeeriwin Zeriman, five ; to 'Tisheet, ten; to Benown, ten.

On the 30th of April, the Moorish camp broke up from Benowm, at the approach of the army of Bambarra to the frontiers of Ludamar, and retreated by the way of Farani, towards the north, to an encampment in the vicimity of Bubaker, a town inhabited by the negroes. Here Mr Park had an interview with Fatima, the queen, who was at first shocked with the appearance of a Christian, but 
became soon reconciled to him, when he had answered her a number of questions concerning the country of the Christians. This lady seemed to compassionate his situation, and, from her, he received the only instances of kindness which he experienced in Ludamar. The country around Bubaker presented only a dreary waste of sand, diversified with dwarf trees and prickly bushes, scattered at intervals. The insufferable heat had destroyed vegetation, and dried up almost all the water; nature seemed sinking under its influence, and the stillness of the desert prevailed, except at the watering-places, where it was interrupted by the constant lowing of the cattle, furious with thirst, that contended around the wells, while those that were too weak to endure a struggle, devoured the black mud in their vicinity. From this scarcity of water, Mr Park suffered severely, though he received some supplies from Fatima; and, as the Moors at the wells were afraid of polluting their vessels by the touch of a Christian, he was forced, when he could procure water, to drink from the troughs along with the cows. The rainy season now approached, when the Moors annually retire to the Great Desert, and no opportunity occurred of effecting his escape, when he obtained leave, through the intercession of Fatima, to accompany Ali to Jarra, where he went to treat with the fugitive Kaartans, who solicited his assistance 
against Daisy, their native prince. From the first watering-place which they reached after their departure from Bubaker, the boy Demba was sent back to the Moorish camp, to the deep regret of Mr Park, who remonstrated in the strongest terms to Ali, but was only told, with a haughty look and malignant smile, that if he did not immediately mount his horse, he should likewise be sent back to Bubaker. At their arrival in Jarra, Mr Park immediately requested Daman Jumma, the Slatee, to negociate the release of Demba with Ali, who refused it, upon the pretext, that he was the principal interpreter of the Christian, and might perhaps conduct him to Bambarra; but agreed, when there should be no danger of this, to transfer him to the Slatee at the common price of a slave. The fugitive Kaartans offered to hire 200 of Ali's cavalry; which the Moorish prince, with the warmest professions of friendship, agreed to furnish, upon condition that they should previously supply him with 400 head of cattle, 200 garments of blue cloth, and a considerable quantity of beads and ornaments. To this stipulation they agreed; and, soon after Ali had received the articles, they were informed, by fugitives from Kasson and Kaarta, that Daisy, who had been informed of their intended attack, proposed immediately to visit Jarra. In order to anticipate him, they raised about 800 men, and entered Kaarta on the 18th of June. 
They also demanded their Moorish auxiliaries from Ali; but that perfidious prince informed them, that his cavalry " were otherwise employed." On the 24th, the army of the confederates returned without venturing to encounter Daisy, after plundering some of his villages. But, on the 26th, the alarming intelligence arrived, that the king of Kaarta was on his march to Jarra, and had already taken Simbing. The inhabitants immediately prepared to evacuate the town, and the women continued all night beating corn, and packing up their most necessary articles. Next morning, the greater number departed from Bambarra, by the way of Deena, driving their sheep, cows, and goats, and carrying a small quantity of provisions and clothes. Lamentation resounded along the road; the women and children were crying; the men were sullen and dejected, and, as they travelled on, frequently paused to view their native city, and the wells and rocks to which all their plans of ambition and of happiness had been confined. The centinels soon after reported, that the confederate army had fled before Daisy, without firing a gun ; upon which the screams of the women and children redoubled, the remaining inhabitants deserted the town, and Mr Park, dreading to be mistaken for a Moor in the confusion of victory, mounted his horse, took a bag of corn behind him, and joined the fugitives. At Queira he waited a few days 
for the arrival of some Mandingoes who were going to Bambarra, when Ali's chief slave arrived with four Moors to conduct him to Bubaker. Two of them proposed to secure his horse; but, as it appeared impossible to escape upon such an animal, they neglected this precaution. At this alarming intelligence, Mr Park resolved to attempt an escape; and, packing up his clothes, which now consisted of two shirts, two pocket-handkerchiefs, and two pair of trowsers, an upper and under waistcoat, a cloak, a hat, and a pair of half-boots, as soon as the Moors were asleep, he stepped over the Negroes, who were sleeping in the open air, mounted his horse in great perturbation, and departed. When he had advanced a few miles, he saw himself pursued by three Moors, who were hooping and brandishing their double-barrelled guns. Mr Park now lost all hope of escaping, and resigned himself to his fate with the indifference of despair; but his pursuers were contented with plundering him of his cloak. At the departure of the Moors, he entered the wilderness, directing his course E. S. E. by the compass; the heat of the sun was increased by the reflection of the sand, and the ridges of the hills seemed to fluctuate like the sea, in the ascending vapour. Mr Park began to grow faint with thirst, and the horse restive from fatigue. Often did he climb the tallest trees, to look for the ascending 
smoke of some village, or the traces of human habitations, but nothing appeared on the level horizon, but thick underwood and hillocks of white sand. The leaves of the trees which he chewed were bitter, but were devoured by the horse ; and, as his fate seemed now inevitable, he took off the bridle, and, exhausted with fatigue, and affected with sickness and giddiness, sunk upon the sand in a state of insensibility. Recovering at length, he found the bridle in his hand; and, as the sun was sinking beneath the horizon, determined to make another exertion. As the darkness increased, he perceived some flashes of lightning, which indicated rain; the wind immediately began to roar among the bushes; and, when he opened his mouth to receive the drops, he found himself covered with a shower of sand. In a little while the sand ceased to fly, and the expected shower arrived, when Mr Park spread out his clothes to collect the rain, and, by wringing and sucking them, quenched his thirst. Directing his way by the compass, which the flashes of lightning enabled him to view, he reached a Moorish watering-place about midnight, and, avoiding their tents, discovered some shallow muddy pools of water, by what he emphatically terms the heavenly music of the frogs, that completely covered the surface of the pools. Next day he arrived at Shrilla, a Foulah village, subject to Ludamar, where the Dooty re- 
fused to relieve his necessities, and the men proposed to convey him back to Ali. Mr Park deceived them, taking a retrograde direction, as if he had been returning to the Moors; but before his departure, he addressed a venerable old woman, who was spinning cotton at the door of one of the huts, and made signs that he was hungry; upon which she invited him to enter her hut, set before him a bowl of kouskous, and also procured corn for his horse. Mr Park presented her with one of his pocket handkerchiefs. All day he traversed a fertile country; the third day the track became more hilly, and he arrived at a wateringplace belonging to the Foulhas, where he was received with great hospitality. Journeying on during the night, at the approach of some travellers, he concealed himself among the thickets, where he sat, holding his horse by the nose, with both his hands, in equal danger from the travellers in the open ground, and the wild beasts by which the bushes were haunted. Next day, July 5 th, he reached Wawra, a small town surrounded with high walls, inhabited by Mandingoes and Foulahs, subject to Bambarra. He was now beyond the boundaries of Ludamar and the tyranny of Ali. Though this prince had been successful in his former wars against Bambarra, his army never exceeded 2000 cavalry. But though these compose his military force, they form but a small proportion of his Moor- 
ish subjects, though Mr Park had no accurate method of estimating their population. The troops of Ludamar receive no pay, except what they derive from plunder. Their horses are excellent, and are often purchased by the negro chiefs at the rate of fourteen slaves. The dress of the Moors is similar to that of the negroes, and only distinguished by the turban, which is none of the least obvious characteristics of a Mahometan. Length of beard is venerated as a mark of Arabian extraction. Mr Park's beard, which the Moors seemed to regard as too good a beard for a Christian, was the only circumstance in his person or character which excited their approbation. Capital punishments are seldom inflicted in Ludamar, except upon the negroes. The Moors spend the day chiefly in conversing about their horses, or planning depredations on the negro villages. As the king's tent is the chief public place, they often amuse themselves by chanting songs of adulation in his praise. It cannot be denied, that, in every nation, that quality which causes revolutions, which elevates and destroys the works of men, which constitutes and abolishes laws, which founds, and which undermines empires and kingdoms, force, which predominates in human affairs, has been more frequently the subject of the poet's panegyric, than any of the mild and useful virtues. Every nation applauds those qualities that are useful to 
itself. Civilized nations praise talents and virtues, -savages hunting and fishing. The expences of the king of Ludamar are defrayed by the taxes of his negro subjects. In magnificence of dress and equipage, he exceeds the other Moors, but on common occasions, the distinctions of prince and subjects are forgotten, and his majesty reposes on the same mat, and eats out of the same bowl, with his cameldriver. Among the Moorish women, corpulence and beauty are nearly synonymous; a perfect beauty is a load for a camel, and a fine woman is unable to walk without a slave under each arm to support her. In order to acquire this artificial plumpness, the young girls are crammed, involuntarily, with milk and kouskous, their mothers standing over them with a rod to enforce obedience.

From Wawra, Mr Park proceeded to Dingyee, where a Foulah, who received him with great hospitality, requested, at his departure, a lock of his hair, to make a saphie, imagining that a saphie, formed of the hair of white men, would bestow upon its possessor all the knowledge of the original owner. After indulging the Foulah's desire of knowledge, he advanced to Wassiboo, a small town in N. lat. $14^{\circ} 49^{\prime}$, where the cultivation of corn is carried on to such an extent, that "hunger " is never known." Men and women labour in concert, and, in planting corn, use a padile superior to that of the Gambian negroes; but the fre- 
quent incursions of the Moors force them to carry their arms into the field, with their instruments of agriculture. From Wassiboo, he proceeded by Satilè and Galloo, along with some fugitive Kaartans, to Moorja, a large town, where an extensive commerce in salt is carried on by the Moors, who exchange it for corn and cotton-cloth. The natives, who are Mahometans, are very hospitable, but prohibit Kafirs to drink corn-spirit, or beer. Advancing through a fertile romantic country, by Datliboo and Fanimboo, large villages, they reached Doolinkeaboo. As they approached Sego, the number of passengers on the roads augmented, and the people became less hospitable; but he observed, for the first time in Africa, that women were here admitted into society. Mr Park was constantly mistaken for a Moor by the Bambarrans, who jested upon the sorry appearance of himself and his horse, and affected to think that he had been at Mecca. On July 21st he reached Sego, and, a little before his arrival, he had the inexpressible satisfaction of beholding the long-sought majestic Niger, glittering to the morning-sun, as broad as the Thames at Westminster, and flowing slowly from west to east. Mr Park immediately hastened to the brink, and, having drank of the water, returned fervent thanks to God, for having crowned his labours thus far with success. Sego, the capital of Bambarra, which lies in N. lat. $14^{\circ}$ 
$10^{\prime}$, and W. long. $2^{\circ} 26^{\prime}$; 618 miles from Medina, the capital of Woolli, contains about 30,000 inhabitants. It consists of four distinct towns, two of which are situated on the northern, and two on the southern, bank of the Niger. They are surrounded with high mud walls; the houses are of a square form, with flat roofs, and are built of clay; some of them consist of two stories, and many are white-washed. The streets are narrow, and Moorish mosques appear in every quarter. It was a market-day when Mr Park arrived at Sego, and such crowds were crossing the river, that he waited above two hours for a passage. In the meantime, Mansong, the king, was informed that a white man was coming to see him; and, having been prepossessed against him by the Moors and Slatees residing at Sego, sent one of his chief men to forbid him to pass the river, till the king was informed concerning the object of his journey. The messenger directed him to lodge at a distant village, and promised to visit him in the morning. Mr Park observed, that the canoes upon the river were of considerable size, but had neither decks nor masts. They were formed of two large trees, made concave, and united longitudinally, with their ends to each other, which structure rendered them inconveniently long, and disproportionally narrow. The language of Bambarra he found to be a corrupted species of Mandingo, which he soon under- 
stood and spoke. On arriving at the village to which he had been directed, the inhabitants, who viewed him with fear and wonder, refused to give him food, or admit him into their houses. $\mathrm{Mr}$ Park took the bridle and saddle off' his horse, and turned him loose to graze. The wind rose, and threatened a heavy rain, and Mr Park was sitting, weary and dejected, under a tree, when he was observed by a woman returning from the field, who, learning his situation, with looks of compassion, took up his bridle and saddle, and told him to follow her. She conducted him into her hut, lighted a lamp, gave him broiled fish to eat, and a mat to repose upon, and, with some young women, began to spin cotton. During this labour, which continued great part of the night, they amused themselves with songs, in one of which, composed extempore, Mr Park was much surprised to find that his own story was the theme. " The winds roared, and the rains fell. The poor " white man, faint and weary, came and sat under " our tree. He has no mother to bring him milk, " no wife to grind his corn. Chorus.-Let us " pity the white man-no mother has he," \&c. Mr Park was deeply affected by this instance of kindness to an unprotected stranger, but the only mark of gratitude in his power to bestow, was to present his benevolent hostess with two of the four brass buttons which remained on his waistcoat. 
Next morning, a messenger arrived from the king of Bambarra, who inquired if Mr Park had brought any present, and was informed that he had been robbed of every thing by the Moors. He departed, and, in the afternoon, another messenger announced the order of the king to leave the vicinity of Sego, and presented him with 5000 cowries, which Mansong, desirous of relieving a white man, had sent him to purchase provisions on his journey. Mr Park estimates 250 cowries at the value of a shilling; and such is the proportion between their value and the price of provisions, that a man and his horse can subsist upon 100 for 24 hours. From the messenger, who was instructed to conduct him to Sansanding, if he intended to visit Jennè, he learned that the king of Bambarra had only been deterred from admitting him to his presence by the violence of the Moors, and the apprehension that it would be impossible to protect him from their malignity. The character, indeed, in which Mr Park appeared, was extremely suspicious, and could hardly be distinguished from that of a vagabond or fugitive. When he related to the Bambarrans, that he had come from a great distance, and passed through many dangers, to behold the Joliba river, they naturally inquired whether there were no rivers in his own country, and whether one river was not like another, over all the world. The guide praised the hospitality of the 
Bambarrans, but related, that Jennè was entirely under the influence of the Moors, and only a nominal part of the dominions of Bambarra. Mr Park, however, had proceeded too far to recede upon vague report, and resolved to verify it on the spot; and, for this purpose, leaving Sego on the 23d, he advanced by Kabba to Sansanding. The extensive city of Sego, the canoes with which the river was covered, the numerous population, and the improved state of cultivation in the beautiful country which he traversed, presented a prospect of civilization which recalled more forcibly to his memory the centre of England, than the ideas he had formed of the heart of Africa. The inhabitants of the country were occupied in collecting the fruit of the shea-tree, from which the vegetable butter is prepared, which forms a principal article of commerce in the interior districts. The shea-tree, which resembles the American oak, is indigenous in Bambarra, and is left growing, when the woodland is cleared. The butter is prepared from the kernel, which resembles a Spanish olive, and is enclosed in a sweet pulp, under a thin green rind. It is dried in the sun, and then boiled in water; the butter is whiter, firmer, and better flavoured than that of milk. Sansanding contains nearly 10,000 inhabitants, and is a considerable mart of Moorish commerce. Here Mr Park was mistaken for a Moor by the negroes, but was soon discover- 
ed by the Moors, who accosted him with their usual arrogance and insolence, requiring him to recite the Mahometan prayers, in imitation of the Jews, who, notwithstanding this conformity, and their general similarity to the Moors, are reckoned inferior to the Christians. $\mathrm{Mr}$ Park declared, that he could not speak Arabic; when a Shereef from Tuat, in the great desert, sprung up, and swore by the Prophet, that, if he refused to go to the mosque, he would be one that would assist in carrying him ; when the Dooty, to whom he was conducted by the guide, interposed, and declared, that he was the king's stranger, and that he should not be injured while under his protection. At sunset, he was conducted into a neat hut, with a court before it, which was immediately filled with Moors, who clambered over the mud wall, in order to see him perform his evening devotions, and eat eggs. Mr Park assured them, that he had no objection to eat eggs, if they would give him eggs to eat. When a number of eggs were brought by the landlord, they were muoh surprised that he could not eat them raw, imagining that Europeans subsisted chiefly on this food. But when the landlord discovered that a white man ate the same kind of food as other persons, he entertained him very kindly with plain substantial mutton. When the Moors had departed, he requested him to write a saphie, for, said he, " if a Moor's saphie be good, a white man's VOL. I. A a 
" must be better." Upon which Mr Park furnished him with one of the best he could recollect, by writing the Lord's prayer on a thin board, with a reed. On the 25 th of July, he left Sansanding, and proceeded by Sibili, Nyara, and Nyamee, to Modiboo. Between Nyamee and Modiboo, he observed the guide examining the bushes with great caution, and, inquiring the cause, was informed that the woods were infested with lions. As they were crossing an open plain, interspersed with bushes, the guide suddenly wheeled round, and exclaimed, "A very large lion!" As Mr Park's horse was much fatigued, they rode slowly along; and began to think the alarm groundless, when he perceived a large red lion, couching with his head between his paws. Mr Park immediately disengaged his feet from the stirrups, in order to throw himself on the ground, but, while his eyes were rivetted upon the animal, his horse carried him slowly to a considerable distance, and the lion calmly retained his position. Soon after leaving Modiboo, his horse stumbled on the rough clayey ground, and, as he could not raise him up, he was forced to leave him, with the sad presage, that he should soon lie down and perish in the same manner, exhausted by hunger and fatigue. When he reached Kea, a small fishing village, he entreated the protection of the Dooty, who in: formed him coolly, that he paid no attention to 
fine speeches, and that he should not enter his house. From Kea, he was transported in a canoe to Moorzan, a fishing town on the northern bank, whence he was conveyed across the Niger to Silla, a large town, situated in N. lat. $14^{\circ} 48^{\prime}$, and W. long. $1^{\circ} 21^{\prime}$, about 1090 British miles east of Cape Verd, and in the same parallel. At Silla, Mr Park found himself exhausted with sickness, hunger; and fatigue, half-naked, and without any article of value to procure provisions, clothes, or lodging. The intolerant fanaticism of the Moors, whose influence increased as he advanced, and the violence of the tropical rains, by which the swamps and ricegrounds were already inundated, presented insuperable obstacles to his progress. Inevitable destruction menaced him on the one hand, and the dangers of a journey on foot, for several hundred miles, through nations and regions entirely unknown, awaited him on the other. In this extremity, he resolved to accept the only alternative which circumstances presented, and to attempt the preservation of those discoveries which he had made, by returning to the Gambia. He had now approached within 200 miles of 'Tombuctoo, which had long been the object of research of the Portuguese, the French; and the English; he had ascertained the direction of the Niger, and followed its course for seventy miles to the east ; and he now endeavoured, before his return, to collect from the Moorish 
and negro traders, an account of its farther course, and of the kingdoms in its vicinity. He was informed that Jenné, a large town, containing a greater number of inhabitants than Sego, or any other city in Bambarra, is situated on a small island in the Niger, at the distance of two days' journey from Silla. 'Two days' journey below Jenné, the river expands into a considerable lake, termed Dibbie, the dark lake, in crossing which, from west to east, the canoes lose sight of land for one whole day. From the lake Dibbie, the river issues in a number of streams, which, at a lower point, unite in two large branches, which, separating to a great distance, enclose the island Ginbala or Guinbala, which is about 100 miles in length. Ginbala is inhabited by negroes, who live in considerable affluence, as the country is often visited by traders; who pass from the west to Tombuctoo, and who, from the swampy nature of the soil, intersected by numerous creeks, have been able to resist all the power of the Moors. The soil of this island. is extremely fertile. 'The two great branches of the Niger, which insulate Ginbala, unite at Kabra, the port of Tombuctoo, which is one day's journey to the south of that city. On the northern banks of the Niger, at a small distance from Silla, the pastoral kingdom of Massina commences, inhabited by Foulhas, who are tributary to Bambarra. On the north-east of Massina lies the king- 
dom of Tombuctoo, the capital of which is the principal emporium of the Moorish commerce in Africa. The government is in the hands of the Moors, who are more intolerant than in any other country. Mr Park was informed, by a respectable negro, that, when he first visited Tombuctoo, he took up his lodging in a public inn, when the landlord conducted him into his hut, spread a mat on the floor, laid a rope upon it, and thus addressed him : "If you are a Mussulman, you " are my friend, sit down; but, if you are a Kafir, " you are my slave, and with this rope I will lead " you to market." The present king of Tombuctoo is named Abu Abrahima; his court is splendid and magnificent; he possesses immense riches, and the expences of government are defrayed by a tax on merchandise. Houssa, the capital of a powerful kingdom, which lies to the eastward, is also a great mart of Moorish commerce, more extensive and populous than Tombuctoo, which it resembles in government and police, as well as in trade. At Houssa, the negroes are more numerous than at Tombuctoo, and possess a share in the government. The Niger passes to the south of Houssa, at the distance of two days' journey, but its farther course is unknown, and the traders who arrive at Tombuctoo and Houssa, from the east, are ignorant of its termination, and only declare, in general terms, that it runs towards the rising sun, to the end of the world. At Jenné, a language entirely dif- 
ferent from that of Bambarra, termed by the negroes Jenné Kummo, and by the Moors Kalam Soudan, begins to be spoken; but the merchants of the east use languages which are quite unknown. At Silla, Mr Park saw quivers and arrows of curious workmanship, which had come from Cassina. On the south of Ginbala lies the extensive negro kingdom of Gotto, the capital of which is named Moosee, after a chief who had the address to unite the petty states into which the country was formerly subdivided, in a confederacy against Bambarra. Being appointed general, he embarked a theet of canoes on the lake Dibbie, and, sailing up the Niger, took Jenné by storm, and forced the king of Bambarra to sue for peace, which was granted on condition of paying an annual tribute of slaves; and Moosee, returning to Gotto, was declared king of the country. On the west of Gotto lies Baedoo, which is tributary to Bambarra. On the west of Baedoo lies Maniana, the inhabitants of which have been engaged in frequent hostilities with the Bambarrans, and are represented by them as cruel ferocious cannibals, who never give quarter to their enemies.

From Silla, Mr Park returned by the same route, as the road along the southern bank of the Niger was represented as impassable, from the swampy grounds inundated, and the creeks flooded by the periodical rains, As he could not al. 
ways procure a guide, he was often obliged to wade breast-deep across the swamps; and though he recovered his horse at Modiboo, his journey was not only uncomfortable and dangerous, but his reception was every where more unfavourable than in his journey to Silla. At Sansanding, he learned that the suspicions concerning the object of his journey had so much increased, that he was universally believed to be a spy; and he was inform. ed that the king of Bambarra had dispatched a canoe to Jenné to bring him back to Sego. This intelligence had almost determined $\mathrm{Mr}$ Park to swim his horse across the Niger, and attempt to penetrate to Cape Coast, through Kong or Gonjah, which was ten days' journey to the south. But, on considering the dangers which it was necessary to encounter, among nations whose language and manners were equally unknown, he resolved to advance towards the west along the $\mathrm{Ni}$ ger, and ascertain its navigable course in that direction. Leaving the vicinity of Sego, on the 13th of August, he travelled rapidly over a populous and fertile country, but through roads which the mud rendered almost impassable, frequently swimming over the creeks with the bridle of his horse in his teeth, and his papers in the crown of his hat; mistaken frequently for a Moor ; always received with rudeness and suspicion, subsisting on the same raw corn with his horse, unless when the superstition of the 
negroes induced them to purchase a white man's saphie, for a meal of rice or milk. 'Two days' journey from Sego, he passed Sai, a large town, the walls of which, at the distance of two hundred yards, were surrounded by two deep trenches, flanked with square towers, like a regular fortification. The inhabitants informed him, that, fifteen years ago, the Dooty of Sai had two sons killed in the war of Maniana, and refused, at the order of the king, to send his sole surviving son to join the army of Bambarra. The incensed monarch, on his return from Maniana, laid siege to Sai, and as the inhabitants refused to surrender, though reduced to such an extremity by famine, that they devoured the bark and leaves of their Bentang tree, the king proclaimed, that, if they would open the gates, no person should suffer injury, except the Dooty. The Dooty immediately resolved to sacrifice himself for the city, and walked out of the camp of Bambarra, where he was put to death, after which his son was massacred, and the inhabitants sold for slaves. At the village of Song, the people refused to receive him within the gate, though the country was infested with lions. Mr Park collected grass for his horse, and lay down under a tree near the gate, but was soon roused by the roar of a lion, which advanced so near, that he heard him rustling among the grass, and immediately climbed the tree for safety. 
The inhabitants, who believed him to be a Moor, would not admit him till midnight ; when, convinced of their error, they opened the gates, declaring that no Moor ever waited long at the gate of a city without cursing the inhabitants. Being about to swim over the river Frina, he had fastened his clothes upon the saddle, and was standing up to the neck in the water, pulling the horse by the bridle, when a negro, who accidentally approached, called to him yehemently to come out, otherwise the alligators would devour both him and his horse. Emerging from the stream, the native, who had never seen an European, was astonished, and exclaimed, in a low voice, "God preserve me! who is this ?" but, on hearing that he could speak the Bambarra language, assisted him to cross the river, and conducted him to Taffara. At this place the inhabitants speak the pure Mandingo. From Taffara, Mr Park proceeded, by Jaba and Somino, to the village of Sooha, where the Dooty refused to sell or give him food, and, calling one of his slaves, directed him to form a pit, while he continued to mutter some unconnected sentences, such as, "good "for nothing,"- - a real plague." But as the pit began to assume the appearance of a grave, Mr Park, who had lingered for some time, suspecting it might be intended for himself, mounted his horse with some expedition, when the slave dispelled his apprehensions, by bringing the corpse of 
a boy for interment. It was thrown carelessly in, the brutal master merely calling out, "money "lost! money lost!" Our traveller now advanced successively to Koolikorro, Marrabou, and Bammakoo, where the Niger first becomes navigable, 50 miles from Kamaliah in Manding, and 10 journeys from Sego. At Bammakoo, Mr Park was informed, that the only pervious route passed through Manding, by Sibidooloo, to which town a jilli-kea, or singing-man, undertook to conduct him. After travelling two miles up a rocky glen, his musical companion discovered that he had mistaken tise horse road, and, mointing over some steep rocks, left Mr Park to admire his agility, and discover his own route. After regaining the road, he traversed some high rocky grounds, where the soil was shallow, and the rocks consisted of ironstone, and schistus, with nodules of white quartz. On the south-east, he saw the mountains of Kong, which, he was informed, were situated in a large kingdom, more powerful than Bambarra. In the evening, he reached the romantic village of Kooma, belonging to a Mandingo merchant, by whom he was received with the greatest kindness, and was soon surrounded by a circle of curious villagers, who, free from the depredations of war, exhibited, among these natural fastnesses, much native benevolence and pastoral simplicity. Next day, on his road to Sibidooloo, he was stripped and plundered 
of his horse, and of almost all his clothes, by some marauding inhabitants of Focladoo. Mr Park supposed them to be elephant-hunters, but was soon undeceived; he begged earnestly for his pocketcompass, but could only obtain from them the worst of his two shirts, and a pair of trowsers. The robbers took his hat, but returned it when they perceived the papers in the crown of it. Robbed, and left naked and solitary in the wilderness, in the midst of the rainy season, above 500 miles from the nearest European settlement, he began to despond, and it seemed to him that no alternative remained, but to lie down and perish. In this forlorn situation, he was solely supported and animated by the consolations of religion. At the moment when his mind was agitated by emotions of the most exquisite pain, when memory represented his friends and native country, only to increase his sufferings, by. the torture of vain regret, the beauty of a small moss, in fructification, irresistibly attracted his attention; and though the whole plant was not larger than the tip of his finger, he could not contemplate the delicate conformation of the root, leaves, and capsula, without admiration. He then thought-Can the Being who planted, watered, and brought to perfection, in this obscure part of the world, a thing which appears of so small im portance, look with unconcern on the situation and sufferings of beings formed after his own image? 
He sprung up with renovated hopes, and, travelling forward, soon reached a village, when he proceeded to Sibidooloo, which he reached in the evening. Sibidooloo, the frontier town of Manding, is situated in a fertile valley, circumscribed by elevated rocky grounds, which are scarcely accessible to horse. It had never been plundered in the wars of the Bambarrans, Foulhas, and Mandingoes: He stated his situation to the Dooty, who interested himself in his cause with great humanity, and promised to recover his horse and effects; but, as the scarcity of provisions was very great, $\mathrm{Mr}$ Park resolved not to trespass on the humanity of the Dooty, (who is termed the Mansa in Manding,) but proceeded on his journey to Wonda, a small town with a mosque, surrounded with a high wall. At one of the villages which he passed, he ate of an uncommon species of food, composed of the blossoms of maize stewed in milk and water. At Wonda, he remained for nine days, affected with severe feverish symptoms, occasioned by the united influence of mental anxiety, corporeal fatigue, and exposure to the heat of the day, and the dews of night, almost without clothes. These symptoms he could not conceal from his landlord, whom he overheard observing to-his wife, that their guest would probably occasion them much trouble and cost; as, for the sake of their good 
name, they would be forced to maintain him till he should either recover or die.

On the 6th of September, his horse and clothes were brought from Sibidooloo, where they had been recovered by the Mansa. But, as the roads were improper for travelling on horseback, at his departure, he presented him to his landlord, and desired him to send the saddle and bridle as a present to the Mansa of Sibidooloo. His landlord presented him with a spear, and leather bag to contain his clothes. The scarcity of provisions was so great, that mothers frequently sold one of their children to maintain the rest of the family. From Wonda he advanced to the villages of Ballanti and Nemacoo, where he could obtain no provision, as the people were almost starving. As it rained hard next day, he remained in the hut, where he was visited by Modi Lemina Taura, a negro trader, who brought him provisions, and conducted. him next day to his own house at Kinyetoo, where he remained a few days. Passing through Dosita, he reached Mansia, a considerable town, where gold is collected. The Mansa sent him a little corn for supper, but demanded something in return, and Mr Park answering, that he had no article of value, he replied, " that his white skin " should not protect him if he told lies." Next day he arrived at Kamaliah, a small town situated at the bottom of some rocky hills, where gold is 
collected in considerable quantities. The proper town is inhabited by the Kafirs, and the huts of the Bushreens are built at a little distance, beside their missura or mosque, a square piece of levelled ground, surrounded by the trunks of trees. Here, in a country where famine prevalled, sickly and cshausted, with the rapid river Kokoro, and the moomy wilds of Jallonkadoo before him, Mr Park thonght he could almost point out the spot where he was to perish, when he was unexpectedly relieved from the deepest distress, by the kindness of a benevolent negro. Being conducted to the house of a Bushreen, named Karfa Taura, who was collecting a caravan of slaves, to be conducted to the Gambia; at the termination of the periodical rains, he found him reading an Arabic book to some Slatees that were to join him. As the other Slatees Irad seen Europeans on the coast, they suspected Mr Park to be an Arab, from the yellowness of his complexion, occasioned by sickness, his long beard, ragged clothes, and extreme poverty. Karfa inquired if he understood Arabic, and, being answered in the negative, caused a little book to be brought, which had come from the west, which $\mathrm{Mr}$ Park was surprised to find the Book of Common Prayer. When Karfa perceived that he could read this book, he had no doubt that he was a white, and promised every possible assistance. $\mathrm{He}$ informed him that he intended to proceed to the 
Gambia, as soon as the grass was burnt, and the rivers could be forded, and advised him to stay and accompany the caravan, as it was impossible for a single white to pass the wilds of Jallonkadoo, when the natives could not travel through the country. Mr Park answered, that, having expended his money; he must either remain to perish with hunger, or beg his subsistence on his journey; when the benevolent negro assured him, that if he could subsist upon the country victuals, he would maintain him till the termination of the rains, and conduct him to the Gambia, where he might reward him as he thought proper. Mr Park offered to pay him the value of a prime slave, which he agreed to accept, and immediately appropriated a hut to his use, and, notwithstanding the malicious insinuations of the invidious Slatees, continued to treat him with the kindest attention. But no accommodation could suspend the progress of the fever, which had gradually acquired strength, and now became so violent, that, during five weeks, he was confined to his hut, and so debilitated, that he could hardly stand upright. In the beginning of December, a Serawoolli Slatee arrived from Sego with slaves, one of whom asked Mr Park to give him some food; and, upon his answering that he was a stranger, the slave replied, "I gave you victuals " when you were hungry. Have you forgot the " man who brought you milk at Karankalla?" ad- 
ding with a sigh, " the irons were not then upoif " my legs." Mr Park immediately recollected one of his Kaartan friends, who had been taken by the Bambarrans, and gave him some earth-nuts, which he received from Karfa. On the 19th of December, Karfa went to purchase slaves at Kancaba, a large town on the Niger, where an extensive commerce in gold and slaves is carried on. During his absence he committed his guest to the care of the schoolmaster, a Bushreen of mild manners and tolerant principles, who possessed various books and manuscripts, and read them with indefatigable application. The scholars received their instructions in the morning and evening, and, during the day, were employed as domestic slaves in the service of their master. They are chiefly the children of $\mathrm{Pa}$ gans, who, induced by the desire of knowledge, imbibe and propagate the doctrines of Mahomet, by this mode, which, except at Sierra Leone, has never been attempted by the Christians. $\mathrm{Mr}$ Park believes, that a short introduction to Christianity, elegantly printed in Arabic, and distributed among the negroes, who read that language, would have a wonderful effect in disseminating the mild doctrines of Christianity, and, from its superior elegance and cheapness, might soon be classed among the school-books of Africa. On the 24th of January, Karfa returned from Kancaba; and, as all the Slatees and slaves of the coffle or caravan were as. 
sembled at Kamaliah and its vicinity, various days were appointed for commencing the journey, but were repeatedly changed, till, at last, they all re: solved to remain in Manding till after the fast of Rhamadan. The negroes did not, like the Moors of Ludamar, compel Mr Park to observe this religious ceremony; but, as a testimony of respect for their religious opinions, he fasted three days, voluntarily, which was reckoned sufficient to exempt him from the charge of infidelity. During this residence in Manding, he had an opportunity of acquiring accurate information concerning the manners of the people, and the nature and productions of the soil, though the danger of exciting the suspicions of the natives prevented a very particular investigation. The property of the soil in Manding seemed to be vested in the Mansas, or chief magistrates, as managers of the public concerns, who assign to individuals as much territory as they can cultivate, without infringing the rights of others. As the soil is extremely fertile, the long grass, which, when withered, is used as a species of hay in Ludamar, is annually burned down in Manding and the negro countries. The conflagration presents a scene of stupendous grandeur: at night, the plains and mountains are streaked with lines of fire, and the heavens are inflamed with the reflected light; during the day, moving pillars of smoke VOL. I. B b 
tower to the heavens, and the birds of prey hover round the blaze, to feast on . the reptiles which endeavour to escape the flame.

The gold of Manding is never found in any matrix or vein, but, like that of Bambouk, scattered in small grains of pure metal through the strata of sand or clay. The women chiefly employ themselves in collecting it, and the Mansa of a particular district appoints a day for the purpose, when all that are concerned assemble. A person may collect, in general, during the dry season, as much as is equal to the value of two slaves. Gold abounds every where in Manding and Jallonkadoo, especially in the hilly district of Boori, or Bowriah, four journeys to the north-west of Kamaliah. The gold obtained is either used in commerce, or wrought into ornaments for the women. The standard of value in computation is the minkalli, a quantity of gold in value about 10s. In Bambarra, Kaarta, Jallonkadoo, and the woody districts, elephants are numerous, and often hunted, but never tamed. The negroes cannot believe that ships are built, and voyages undertaken, to procure ivory, only to be used for handles to knives, when pieces of wood would be equally convenient; they, therefore, imagine that it is employed for some more important purpose, which is concealed from the negroes, lest they should raise its price. The system of domestic slavery prevails, in the same manner as on the 
coast; and a free man may lose his liberty in war, resign it in famine, or forfeit it by insolvency, or by the crimes of murder, adultery, and sorcery.

On the 19th of April, which had been fixed as a fortunate day, the coffle, consisting of 73 persons, free men and slaves, after various prayers and superstitious ceremonies, departed from Kamaliah, and proceeded by Bala and Maraboo to Worumbang, the frontier village of Manding. Next day they crossed the Kokoro, a branch of the Senegal, and arrived at Kinytakooro in Jallonkadoo. 'This town they entered in procession, with six singing men, who belonged to the coffle, in front, followed by the free men, after whom came the slaves, fastened by fours to one rope, with a spearman betwixt every four; in the rear advanced the domestic slaves, followed by the free women, and the wives of the Slatees. At the distance of 100 yards from the gate, the singing men raised a song, in which they celebrated the hospitality of the inhabitants to strangers, and their partiality to the Mandingoes. When they arrived at the Bentang, the inhabitants assembled to hear their history, which the singing men related, in a retrograde order, from their arrival to their departure from Kamaliah; after which they were accommodated with lodgings and provisions in the houses of the natives, by whom they were individually invited. On the $23 d$, they entered the Jallonka wilderness, covered with 
thick primeval forests, yet beautifully variegated with hill and dale. Through these wilds they passed rapidly with forced marches, without seeing any human habitation for five days, during which they endured every species of fatigue, and were only stimulated to perseverance by the danger of being left behind in the woods, to perish with hunger, or be devoured by wild beasts, which they heard, during the night, howling around them. On the second day, one of the female slaves refused food, and began to fall behind; being relieved of her burden, she was soon dreadfully stung by a hive of bees, which the coffle had disturbed. Declaring she would rather die than advance another step, the whip was applied, by which she was made to walk a few hours longer, when she sunk completely exhausted. As the Slatees were unwilling to abandon her, she was carried, during the remainder of the day, on a litter formed of bamboos.' Next day, her limbs were so stiff and painful, that she could not move, and was placed, like a corpse, on the back of an ass, whence she was immediately thrown by the refractory animal, and severely bruised. As it was impossible to convey her through the woods, it was proposed to cut her throat; but as Karfa and the schoolmaster of Kamaliah, who formed one of the caravan, refused to consent to this measure, she was abandoned on the road. On the $2 \%$ th, they reached Sooseeta, a small Jallonka village, 
where they found the inbabitants very inhospitable. Next day they arrived at Manna, an unwalled town, the inhabitants of which were collecting the fruit of the nitta-tree, the pod of which is long and narrow, containing a few black seeds, enveloped in a fine powder of a bright yellow colour, like the flower of sulphur, which has a sweet mucilaginous taste. Upon this powder, and the seeds of the bamboo, which, when dressed, taste like rice, they were informed that the inhabitants of Kallo; the district of Jallonkadoo, which lies upon the Ba-fing, or black river, the principal branch of the Senegal, had subsisted during a famine, before their present crops were collected,

The Jallonkas, like the Mandingoes, are governed by petty independent chiefs, between whom animosity commonly subsists. Their country is extensive and hilly. Their language is different from the Mandingo, though many of the words have a great affinity. Their numerals, like those of the Feloops, Jaloffs, Foulhas, and various other African nations, retain the traces of the original digital arithmetic, suggested to rude nations by the five fingers; for the series only proceeds to five, and then recommences five-one, fivetwo, \&c. They crossed the Ba-fing, near Manna, over a bridge constructed of bamboos, placed upon two tall trees, the tops of which are tied together, and left to float on the stream, while the 
roots are fastened to the rocks. This bridge is annually carried down by the rise of the river, and repaired by the inhabitants of Manna, who exact a small contribution from every passenger. Dreading an attack of the Jallonkas, who, as they were informed, intended to plunder the coffle, they traversed a rough stony country, with great rapidity, till they arrived at Malacotta in Woradoo, the native town of the schoolmaster, who, from gratitude to Karfa, entertained them for several days. Malacotta is a large unwalled town, the houses of which are formed of bamboo wicker, plastered with mud. The inhabitants manufacture excellent iron, and form a good soap, by boiling ground-nuts in water, and adding a ley of wood-ashes. During their stay in Malacotta, they received information concerning a religious crusade which had been carried on by the king of Foota Torra, against, the Damel of the Jaloffs, and had become a favourite subject with the minstrels of the country. This zealous prince, being inflamed with an ardent desire of saving the souls of his infidel neighbours, sent an ambassador to the Damel, accompanied with two Bushreens, who carried each a large knife on the top of a pole, and thus explained the emblems of their mission: "With this knife, Abdulkader will con"descend to shave the head of Damel, if Da" mel will embrace the Mahometan faith; and 
" with this other knife, Abdulkader will cut the " throat of Damel, if Damel refuses to embrace " it,-take your choice." The Damel coolly informed the ambassador, that, as he neither chose to have his head shaved, nor his throat cut, he had no choice to make. The king of Foota Torra, . with a powerful army, immediately invaded the Jaloffs, who at first retreated before him, after filling up the wells, destroying their provisions, and carrying off their effects; but soon after surprised him, at a watering-place, during the night, when many of his army were trampled to death by the Jaloff horses, many killed, and a still greater number taken prisoners, among whom was Abdulkader himself. When brought before the Damel, that prince thus addresed him : "Abdulkader, " answer me this question;-If the chance of war " had placed me in your situation, and you in " mine, how would you have treated me?" "I "would have thrust my spear into your heart," said Abdulkader, " and I know that a similar fate " awaits me." " Not so," replied the Damel, " my spear is indeed red with the blood of your " subjects, killed in battle, and I could now give " it a deeper stain, by dipping it in your own; " but this would not build up my towns, nor bring " to life the thousands who fell in the woods. I " will not therefore kill you in cold blood, but I "will retain you as my slave, until I perceive 
" that your presence in your own kingdom will " be no longer dangerous to your neighbours; " and then I will consider of the proper way of " disposing of you." The king of Foota Torra was accordingly retained, and laboured as a slave for three months, when he was restored to his kingdom by the Damel.

On the 7th of May, Mr Park departed with the cofile from Malacotta, and traversing Konkodoo, " the hilly country," which abounds in gold, and Satadoo, which had been much depopulated by the incursions of the Foulhas of Foota Jallo, he arrived at Baniserile, the capital of Dentila, on the 13th. He obtained little information concerning the political state of these regions, which do not lie in so high a level as Manding, Jalionkadoo, Fooladoo, Gadou, and Kasson. The district containing these countries is the most elevated in Western Africa, descending rapidly on the east, but more gradually on the west. It is of a triangular form, extending about 330 miles on the south between Bambarra and Neola, and contracting to sixty or seventy in the space which is occupied by Kasson, between Kajaaga and Kaarta. Bambouk, Konkodoo, (termed Macanna by Labat), Satadoo, and Dentila, which occupy the place of Combregoudou, in that author, are situated on an inferior level, which extends to Kirwanny, where the country begins to descend rapidly to the west, and is denominated 
the land of the setting sun. At Dindikoo, in Konkodoo, Mr Park saw an Albino, or white negro; his complexion was cadaverous; and his hair and skin of a dull white colour, considered by the negroes as the effect of disease. From Baniserile, they advanced to Kirwanny, a large town situated in a valley. The inhabitants of this town are ac: tive and industrious, and their agriculture is more improved than any of their neighbours. Advancing through the Tenda wilderness, a rugged sloping country, covered with wood, on the second day they arrived at Tambacunda, a walled town, to the west of which there are no shea trees. Here one of the Slatees had a wife; but, on his arrival, he found her married to another, who refused to deliver ber up, alleging that she was at liberty to marry, by an African law, which permits this privilege to any woman, whose husband is absent three years without informing her he is alive. After holding a palaver on the subject, it was determined that the wife should take her choice of the two husbands. They departed from Tambacunda on the 26th, and after passing 'Tenda, and crossing the Nerico, the sixth stream which $\mathrm{Mr}$ Park had observed to fall into the Gambia from the N. E., their arrival in the country of the west, or the land of the setting sun, was celebrated by the singing-men. They soon after reached Seesukunda, in Woolli. The slaves had collected great quantities of the fruit of 
the nitta tree, but were not permitted to bring it within the village, as the inhabitants believed that some great calamity would happen to the place whenever the inhabitants lived upon the nitta. On the 4th they arrived at Medina, and on the day following at Jindey, where $\mathrm{Mr}$ Park had left $\mathrm{Dr}$ Laidley, eighteen months before. Here Karfa left his slaves, after hiring huts for their accommodation, and a piece of land, on which to employ them for raising provisions for their subsistence; and proceeded with one of the Foulhas of the coffle towards Pisania. Mr Park could not leave, without sensible emotion, those unfortunate persons doomed to a life of slavery in a foreign land, who had often alleviated his sufferings, when their own were ininitely greater, who, of their own accord, had often brought him water to quench his thirst, and formed his bed of leaves in the wilderness. At Pisania, he was received like one returned from the dead by Dr Laidley, as all the traders on the Gambia had been informed that he was murdered by the Moors of Ludamar. Dr Laidley undertook to discharge all pecuniary engagements which he had entered into since his departure from the Gambia, and assured Karfa that he would assist him to dispose of his slaves to the best advantage. This respectable negro was surprised when he was informed that he would receive goods to the amount of double the sum which he had been pro- 
mised by $\mathrm{Mr}$ Park, who likewise sent a handsome present to the schoolmaster at Malacotta. But the superiority of the Europeans in manufactures and the arts of civilized life, excited the astonishment of Karfa ; he examined the furniture of the house, the masts, sails, rigging, and construction of the trading schooner; and, with an involuntary sigh, exclaimed, "Black men are nothing." When Mr Park resumed his English dress, he surveyed him with great pleasure, but was displeased at the loss of his beard, which, he said, " had converted " him from a man into a boy." On the 17th of June, Mr Park embarked in an American slavevessel, and proceeded to Goree, where they were detained till the beginning of October. The surgeon having died of a fever, Mr Park acted in his medical capacity during the remainder of the voyage. Many of the slaves had heard of Mr Park in the interior countries, and some of them had seen him. After a voyage of thirty-five days, they reached Antigua, where Mr Park embarked in the Chesterfield packet, and on December the 22d arrived at Falmouth.

Thus terminated the journey of Mr Park, unquestionably the most important ever performed by an European in Nigritia. Though unable to reach Tombuctoo or Houssa, he established a number of geographical positions, in a direct line of 1100 miles, reckoning from Cape Verd; he fixed the 
common boundaries of the Moors and negroes in the interior, and pointed out the sources of the three great rivers, the Senegal, the Gambia, and the Niger. He explained to us the method of proselytism, by which the Mahometan religion is propagated among the negroes; and he illustrated the history of the ancient Lotophagi, . He restored to the Niger its ancient course, and by this means rendered intelligible the descriptions of the interior, which were formerly involved in inextricable confusion. It is impossible, in taking a temporary leave of $\mathrm{Mr}$ Park, not to acknowledge the sagacity and prudence with which he prosecuted his design, the intrepidity with which he encountered the most formidable dangers, and the perseverance with which he surmounted the obstacles which presented themselves to his progress. 


\section{CHAPTER VII.}

MR BROWNE'S JOURNEY.

Departure from Assiut. - Arrival and residence in Darfür.Description of that Country.-Begarmee.-Bergoo.-Dar lulla._Doinga.-The Bahr-el-Abiad.

WhILE Mr Park, with so much intrepidity and perseverance, was attempting to explore Western Africa, according to the plan of the African Association, a private traveller, Mr W. G. Browne, urged by curiosity, and the spirit of adventure, endeavoured to traverse that continent from E. to W. and penetrated into Darfûr, the name of which had been mentioned to Ledyard, but which was entirely unknown to Europeans. The natives of Darfûr, in Egypt, are obsequious in their behaviour even towards the Christians of that country; and were always represented as more tolerant to unbelievers than other Mahometans. Mr Browne imagined, therefore, that when he should arrive in that country, the choice of various routes would be in his power, the length of the journey would be compensated by the superior acquaintance which it 
would enable him to obtain with the peculiar manners of the interior Africans, and the suspicions of the natives would be removed by his favourable reception in one of the interior kingdoms. He believed that it would be equally easy to penetrate into Abyssinia by Kordofan, or to traverse Africa from east to west, by a route which would afford an opportunity of determining various geographical positions, and of observing numerous important facts, both in manners and in commerce. He was informed that the inhabitants of Darfur extended their seleteas, or armed expeditions for procuring slaves, above forty journeys to the south, along the banks of the Bahr-el-Abiad, which he conceived to be the true Nile unexplored by Europeans, and therefore believed, that, by accompanying one of these expeditions, he should not only accomplish this discovery, but traverse at least five degrees of unknown country. With these views, having provided himself at Assiut with five camels, at the price of L. 13 each, he joined the Soudan caravan, and departed from the vicinity of Assiut, on the 28th of May 1793. They journeyed over a sterile mountainous track, and, on the 31 st, arrived at Gebel Ramlie, a rugged mountain of tufa, where, by a steep descent, they entered the desert. From the rock they beheld before them a valley of unbounded extent, covered with rocks and sand, diversified with scattered date trees, and stunted 
bushes. On the second day they reached Elwah, or Al-Wahat, the greater oasis, in which the village of Charjé lies, in N. lat. $20^{\circ} 25^{\prime}$, E. long. $29^{\circ}$ $40^{\prime}$, and Mughess, the most southern village, in N. lat. $25^{\circ} 18^{\prime}$, E. long. $29^{\circ} 3 x^{\prime}$. This oasis produces almost nothing but dates for the subsistence of the inhabitants. Here Mr Browne was informed, that the Oasis Parva, termed Elwah-el-Gurbi, lies about 40 miles to the north. The Oasis Parva is said to contain various ruins, and to be a kind of capital of the Muggrebin Arabs, who are numerous in this desert, and, by uniting, might raise an army of 30,000 men. On the 15 th of June, they left Mughess, and, on the 20th, arrived at Sheb, in N. lat. $23^{\circ} 35^{\prime}$, E, long. $30^{\circ} 10^{\prime}$, where a considerable quantity of native alum is produced, and the soil presents a reddish stone, and argillaceous earth. From Sheb they advanced to Selime, in N. lat. $22^{\circ} 15^{\prime}$, E. long. $30^{\circ} 15^{\prime} 30^{\prime \prime}$, a small verdant spot at the foot of a ridge of rocks. Here they found a small building of loose stones, concerning which the Jelabs related various fables, asserting that it had been formerly inhabited by a martial princess named Selimé, who was the terror of Nubia. After passing by Leghea, in $\mathrm{N}$. lat. $20^{\circ}, 10^{\prime} 30$, and the salt spring, Bir el Malha, in N. lat. $18^{\circ} 8^{\prime}$, E. long. $29^{\circ} 4$, they arrived at Darfür on the $23 \mathrm{~d}$ of July, and lodged in the village of Sweini. Here Mr Browne discovered, that, besides the fatigues of 
the journey; other difficulties remained to be surmounted. The people of the caravan had dispersed, and the natives of Darfûr considered him as an infidel, in whose face the traces of inferiority of species were distinctly marked, and whose colour they regarded as the effect of disease, or as the consequence of the divine displeasure. $\mathrm{He}$ had hired a native of Cairo, who had originally been a slave-broker, to manage his money-transactions in Darfûr, where he was informed every species of commerce was conducted by simple exchange. This person, with whom he had quarrelled on the journey, not only robbed him of several valuable articles, but, by the most consummate treachery, infused suspicions into the mind of the Sultan, prevented him from being admitted to his presence, and procured an order by which he was confined to Cobbè, and forced to lodge in the house of one of the agents in the machination. Here $\mathrm{Mr}$ Browne experienced a sévere attack of a fever and dysentery, by which he was confined for a considerable time. Immediately after his convalescence, he proceeded to El-Fasher, in order to procure an audience of the king, but was received with the most pointed inattention, as he could seldom procure admission to the levees, and never an opportunity of speaking. The effects he had brought to Darfûr, for commerce and presents, were seized, at an arbitrary valuation, for the use 
of the Sultan, notwithstanding his remonstrance. A frivolous charge of violating the female slave of the person with whom he lodged at El-Fasher, being commenced against him, and a very considerable compensation claimed by her master, the Sultan was induced to interfere, and take him under his immediate protection, in order to prevent reprisals from being made on the property of his own subjects in Egypt. Mr Browne resided afterwards with the Melek of the Jelabs, or the officer who presides over the foreign merchants, by whom he was treated with kindness and attention. He endeavoured, by the mediation of this officer, to obtain a compensation for his effects which had been seized, and permission to accompany the armed expeditions for procuring slaves, but was informed that he would certainly perish, either by the jealousy of the depredators whom he accompanied, or the hostility of the tribes on whom they perpetrated these enormities. Renouncing, therefore, this design, he requested permission either to pass into Bergoo, the first Mahometan kingdom on the west, or to Sennaar, through Kordofan ; but the Melek suggested, that both these routes were equally impracticable, from the jealousy which subsisted between Bergoo and Darfür, and the insurrections in Kordofan, and advised him to embrace the first opportunity of returning to Egypt. The journey

VOL. I.

C C 
to Egypt was equally difficult, as the Sultan detained the caravans, while he attempted to negociate with the Beys of Egypt a monopoly of the Soudan trade. The Melek, however, promised to $\mathrm{Mr}$ Browne to exert his influence in order to accomplish some of his plans, but, dying in a few weeks, all hopes from that quarter were frustrated. The Sultan still preserved the same aspect of indifference and inattention; reports were circulated that he intended never to permit $\mathrm{Mr}$ Browne's departure from Darfûr, and these seemed to be countenanced by the imperfect compensation of 120 piastres, which he received for the value of 750 , the estimated value of the goods that had been seized. He sometimes was permitted to see the Sultan, but seldom to hold any species of conversation with him. He attended, without effect, at a great public audience, where the Sultan appeared in great magnificence, seated on a splendid throne, while an officer proclaimed, from time to time, "See " the buffaloe, the offspring of a buffaloe, the bull " of bulls, the elephant of superior strength, the " powerful Sultan Abd-el-rachmân-el-rashîd. May " God preserve thy life! O master, may God as"sist thee, and render thee victorious!" These appellations bestowed on the monarch are similar to the titulary epithets claimed by other barbarous princes, and may serve, in some measure, to mark the degree of civilization attained at the Fû- 
rian court. The kings of Mexico were denominated hackers of men, and drinkers of blood. The king of Achem in Sumatra is designated, Lord of heaven and earth, and of the four and twenty umbrellas, who is as spiritual as a ball is round. The emperor of Monomotapa receives the titles of Great Magician, and Great Thief. During the space of three years that $\mathrm{Mr}$ Browne continued in Darfûr, affairs continued in the same situation; he sometimes acted as a physician; his Egyptian broker attempted to poison him when he could not accomplish his assassination; symptoms of violence appeared in the populace; his resources of subsistence were almost exhausted, and the Sultan's permission to depart from Darfür could not be procured.' Mr Browne had now resource to artifice, and insinuated to the chief of the caravan, and the principal merchants, the danger of appearing without him in Egypt, alleging that he had been able to dispatch to that country intelligence of his situation in Darfûr. These insinuations had their effect, and, by the solicitations of the intimidated merchants, he was graciously permitted by the Sultan to join the caravan, and arrived at Assiut in Egypt in the summer 1796, after an absence of nearly three years. In Darfûr, $\mathrm{Mr}$ Browne made numerous inquiries concerning the neighbouring nations, and the territories which they inhabited, and collected many curious notices. 
Darfûr, which signifies the kingdom of Foor or Fûr, as it is written by Browne, the only European traveller who has visited the country, lies to the S. E. of Bergoo, and is bounded on the E. by Kordofan. The country is of considerable extent, and in many places covered with wood. During the dry season, the appearance of the open country is sterile and barren, but when the rains commence, the dry sandy soil is soon changed into green fields covered with luxuriant vegetation. Considerable quantities of maize, sesame, beans, and legumens, are raised by the inhabitants for food. There are several species of trees in Darfûr, but. the tamarind alone is valuable for its fruit, or rises to a considerable size. The date, which is diminutive, does not appear to be indigenous: Domestic animals are the camel, the sheep, the goat, and horned cattle, which are numerous. Of the milk of the cow, some of the inhabitants make a kind of cheese, but the process is not generally known. The camel is of an inferior quality; and the horse and the ass are imported from Egypt and Nubia. Their wild animals are the lion, the leopard, the hyæna, the wolf, and the wild buffaloe. The termites, or white ants, abound; and the cochineal insect is frequently met with, though it has never been applied to any useful purpose in Darfûr. The rocks are chiefly composed of grey granite, but in a few places, alabaster and marble are 
found. Nitre is produced in considerable quantisies ; fossile salt is found in one district, and sulphur is collected by the pastoral Arabs on the $\mathbf{S}$. and $W$. The principal towns in Darfûr are Cobbè, the chief residence of the merchants, situated in N. L. $14^{\circ} 11^{\prime}$ long. E. Gr. $28^{\circ} 8^{\prime}$. It is above two miles in length, but extremely narrow, containing numerous trees and vacant spaces within its boundaries. Sweini, which commands the northern road to Darfurr, is situated above two journeys to the north of Cobbè. Kourma, a small town, lies twelve or thirteen miles to the south-west of Cobbè, and Cubcubìa, two and an half journeys to the west. Cubcubia commands the western roads, and has a market twice in the week. Cours lies fourteen or fifteen miles to the north-west of Cobbè; Ril, about sixty miles to the south-east of Cobbè, is situated in a fertile plain, commands the southern and eastern roads, and was formerly the residence of the kings of Darfûr. Gidid, Gellé, and Shoba, are the only other remarkable towns. The villages are numerous, but their population seldom exceeds a few hundred inhabitants. The population of Darfûr is estimated by Browne at 200,000 persons. It consists of the native tribes of Fûr, of a deep black complexion, crisped woolly hair, and features different from those of the negroes ; Arabs of the tribes of Mahmid, Mahrea, Beni Fesara, Beni Gerar, \&c. some of whom have settled in the 
country, while others wander on the frontiers, and are very numerous; and a number of emigrants from the neighbouring states, particularly Dongola, Muhas, Sennaar, and Kordofan. Besides these, Darfûr comprehends the inhabitants of various subordinate districts, that are sometimes dependant on Darfûr, and sometimes on the surrounding nations: as Dar Rugna, which is generally subject to Bergoo; Dar Berti, Bégo, or Dageou, between Darfür and Bergoo, the power of which formerly predominated over the Fûrian tribes; and Zeghawa, formerly an independent kingdom, that was accustomed to raise a thousand cavalry in war, the inhabitants of which are different in their features from the negroes. The Zeghawese use a different dialect from the Fûrian tribes. Zeghawa lies in N. lat. $15^{\circ} 1^{\prime}$. Kordofan, a considerable district on the east of Darfûr, lies between that kingdom and Sennaar, and seems to be sometimes independent, and, at other times, subject to the most powerinl of its neighbours. Frequent hostilities have produced an inveterate animosity between the natives of Kordofan and Darfûr. The Kordofanese venerate the memory of Aboucalec, one of their governors, who renounced the allegiance of Sennaar, about the time that $\mathrm{Mr}$ Bruce returned from Abyssinia. At his death, Kordofan was reduced by Darfûr, but had again rebelled when the latter country was visited by Mr Browne, and had 
interrupted entirely the eastern route to Darfûr. The inhabitants of Kordofan are reported to establish connections with strangers, by admitting their intercourse with their female relations, in the same manner as the Abyssinian Galla in Maitsha. The language of Kordofan is Arabic. Ibeit is one of the principal towns. The Arabs and Nubians are distinguished by their olive complexions, expressive features, and short curled black hair, which is not woolly. A tribe of Arabs, on the east of Darfür, curl their hair in the form of a bushy wig, like the sculptured figures in the ruins of Persepolis. The Dongolese residing in Darfûr use the dialect of Barabra, the district of the desert which borders on Egypt. The dialect of Arabic, which is vernacular in Darfür, differs essentially from that spoken in Egypt. The native Fûrians are more cheerful in their dispositions than the Egyptians; but resemble the Moorish tribes in the violence of their passions, their disregard to truth, their inattention to cleanliness, and their inaccurate ideas of property. As the practice of polygamy is established, their intercourse with the other sex is regulated by no attention to delicacy or decency; and the precepts of Istamism are often infringed, by the relations of trother and sister being exchanged for a closer connection. The sex are, however, subjected to less restraint than in many Mahometan countries. The women 
appear in public unveiled, make bargains in the markets, and converse with the other sex, without offending their husbands or relations. The most severe labours of the field, and the meanest domestic offices, are performed by the women, who are often seen walking after their husbands, under the pressure of a heavy burden, while these ride before them on their asses, without encumbrance and without concern. Their houses are built of clay, commonly by the hands of their women, and are covered with a flattish roof of thin boards, coatted with clay. Salt is the general medium of exchange in Darfûr, but, in some places, small tin rings of arbitrary value are employed. A caravan passes from Darfür to Egypt, to traffic in slaves, ivory, gum, camels, \&c.; but this commercial intercourse is not regular, and is frequently interrupted. The Dongolese and Nubian settlers in Darfûr, who had been accustomed to the Egyptian trade, originally opened the route; but merchants are frequently interrupted by the Cubba-besh and $\mathrm{Be}$ deiat Arabs; the last of whom are not supposed to be of Arabic origin. In collecting the harvest, they break the ears of corn leisurely from the stalk, in the same manner as the negoes of Western Africa. At the beginning of the wet season, custom requires that the king and the chief men go out to the field with the cultivators, and engage in the planting of corn. This is prac- 
tised in other countries of Africa, as Bornou and Sennaar, where the king is always entitled Baudy, the peasant, from a similar custom. Herodotus has mentioned a similar practice of the ancient Egyptian kings, and travellers have related, that the same usage is continued by the Chinese monarchs. The king, or, as he is denominated, the Sultan of Darfür, reigns with absolute authority, and confers the same arbitrary power on his delegates in the provinces. Though the precepts of the Koran are the ostensible rules of decision, in cases of litigation, yet the verdict depends on the will of the judge; and, as none but ecclesiastics dare express their sentiments of his conduct, their opinion is the only check upon his caprice. These judges, however, display considerable ingenuity in developing the most intricate cases that occur in a nation versed in the arts of deceit.

The sultan's revenues consist in the taxes upon merchandise exported and imported; the annual tribute of live stock from the Arabs, and of corn from the towns and villages, with the amount of fines, forfeitures, and presents. The armies of Darfûr are not numerous, as 4000 troops are reckoned a formidable number; neither are these troops remarkable for skill, courage, or perseverance, though they endure hunger, thirst, and fatigue, with great resolution, and use no other camp-equipage, but a light mat adapted to the size 
of the body. The troops of Darfür, not actually engaged in war, are reviewed at an annual military festival, termed, The lealhering of the liettle-drum, when presents are presented to the sovereign by all the principal people of the country, and various superstitious ceremonies are performed, among which are the sacrifice of a young boy and a girl. Various superstitions opinions are blended with the Mahometanism of the Fûrian tribes. The mountaineers sacrifice to the deity of the mountains in order to procure rain. Mahometanism began to prevail in Darfur in the reign of Solyman, of the Dageou race, who is supposed by Browne to have lived at some period between 130 and 150 years ago. The Dageou race are reported to have been originally expelled from the vicinity of Tunis, and to have resigned the sceptre to the race of Fûr, after being exhausted by intestine dissensions. At the inauguration of every king, they are said to have kindled a fire, which was preserved burning till his death. At the accession of a sultan, the present Fûrians spread before him various carpets, on which their deceased monarchs used to sit, and from that which obtains the preference, deduce an omen of his future character, which they suppose will resemble its former possessor. The present monarch of Darfür, ambitious, fond of martial reputation, and eager to possess the gold mines of Sennaar, applied to the Mameluk Beys of Egypt 
to furnish him with a person acquainted with the construction of artillery ; and Achmet Aga, a Zanthiote, departed from Cairo for Darfûr in November 1796, carrying with him about 50 artificers, and four pieces of brass cannon. The success of this embassy is unknown. The same monarch, soon after the commencement of his reign, sent an embassy to Constantinople, with a present of three select eunuchs, and three beautiful female slaves. The Ottoman Emperor, who had never before heard of the Sultan of Darfür, returned an ornamented sabre, a rich pelisse, and a diamond ring.

Begarmee lies about twenty journeys to the S. E. of Bornou, from which it is separated by several small deserts. The inhabitants of this extensive kingdom are rigid Mahometans. Though their complexion is black, their features are dissimilar to those of the negroes. Begarmee is fifteen days' journey in length, from N. to S., and twelve in breadth from $\mathrm{E}$. to W. Its troops are numerous, and fight on horseback.

Bergoo, which lies to the E. of Begarmee, and borders on Darfür on the S. E., is reckoned a more powerful kingdom than Begarmee, and extends twenty journeys from N. to S., and fifteen from E. to W. The capital of Bergoo is termed Wara. The inhabitants are rigid Mahometans, and have a mortal aversion to Christians. One day's journey from Wara lie eight large mountains, the 
inhabitants of each of which speak a different language; their religion is Mahometan; they are brave warriors, and increase the armies of Bergoo. The natives of Bergoo lay waste the countries on which they make war, by sudden incursions, and never proceed to the field accompanied by their women, like the inhabitants of Darfûr and other states.

On the S. W., S., and S. E., Darfûr, Bergoo, and Begarmee, are bounded, and in many places intersected, by Pagan tribes, that inhabit woody and mountainous districts, who sometimes submit to their more powerful neighbours, but more frequently assert their independence. Some of these Pagan tribes are represented as formidable warriors, who never retreat from the combat. They fight with poisoned arrows, and ignited spears, which the women heat to redness in fires, which they kindle behind the warriors; and with these they supply them, as their weapons cool. These tribes are chiefly of two descriptions ; of which the one have woolly hair, and exhibit the true features of the Guinea negro; while the other are of a reddish colour, among which are the natives of Harraza on the N. of Kordofan, about N. L. $15^{\circ}$, and Long. E. G. $32^{\circ}$. Tumurkee lies on the W. of Darfûr. Beyond it lie numerous tribes of independent negroes, who are frequently invaded by the Begarmeese and the inhabitants of Bergoo and Darfür, who often proceed forty journeys to the $S$. and $S$. 
W. to seize the inhabitants, and sell them for slaves. The Begarmeese on horseback attack the Kardee, Serrowah, Showva, Battah, and Mulgui tribes, who are represented as idolaters and barbarous cannibals, and, seizing as many captives as possible, drive them like cattle to Begarmee. If they linger on the road, exhausted with famine and fatigue, one of the horsemen seizes the most feeble, or the oldest, smites off his arm, and uses it as a club to drive the rest along. The negroes of GnumGnum devour the flesh of their prisoners; and, stripping the skin from the hands and faces of the slain, after due preparation, wear them in triumph. This seems to be a particular method of scalping. They form their spears of iron, and, after igniting them in the fire, stick them in the trunk of a tree, whose juice is the most deadly poison, where they suffer them to remain till they are crusted with venom.

Darkulla, one of the chief of these negro states, lies to the S. W. of Darfûr and Bergoo, and is intersected by numerous rivers. The inhabitants are partly negroes, and partly red or copper-coloured. The power of the chief seems to vary with his individual ability, which sometimes unites the small detached tribes, and sometimes is unable to accomplish this object. Their language is nasal, but simple and easy. They worship idols, but are remarkable for punctilious honesty in 
their transactions, and are much more cleanly than the nations by whom they are surrounded. They pass their rivers in canoes, which are formed from the trunks of large trees. The smallest injuries are punished by condemning to slavery the young relations of the offender. If the footsteps of a person be observed among the corn of another, or if one person has neglected to execute the commission of another, which he had undertaken, a palaver is held before the chief men, and the son, daughter, nephew, or niece, of the offender, forfeited to him who has sustained the injury: As death is never regarded as a necessary event, whenever a person dies, his death is supposed to have been occasioned by violence or witchcraft, and his neighbours are obliged to drink a species of red water for their justification. These customs, with the feuds and quarrels of rude tribes, supply the slave-markets of Darfûr and Bergoo. The chief article of commerce in Darkulla is salt, 12 pounds of which constitute the value of a young male slave, and 15 that of a female. The Pimento tree abounds in this country. In the mountainous district to the south of Darfür, various kinds of metals are found, and the native tribes are acquainted with the method of extracting both iron and copper from their ores. The copper is of the finest quality, in its pale blue colour resembling that of China, and probably containing a considerable quantity of zinc. The 
district from which it is brought is termed Fertit, the natives of which exhibit the negro features and complexion. It lies about twenty-four journeys to the south of Cobbé, on the Misselad, a considerable river. The merchants who pass towards the sources of the Bahr Misselad, seldom return till the end of two years, and occupy from 150 to 180 days on the route. About eight journeys to the east of the copper-mines of Ferit lie the sources of the Bahr el Abiad, or Westem Nile, termed the White River, from the muddy clay colour of its waters, in contradistinction to the Bahr el Azrac, or Blue River, the Eastern Nile, whose source was explored by Bruce, which receives its denomination from the deep azure colour of its stream. The country is extremely mountainous, and termed Donga, where the Pagan chief resides. The inhabitants are black, and are sometimes kidnapped by the inhabitants of Bergoo. The river rises from forty distinct hills, termed Kumri, or the Mountains of the Moon, from which numerous streams descend, which, uniting in one channel, form the Western Nile.

Zamfara, or Zanfara, was mentioned to Mr Browne as a country near Bornou, but he never heard of Wangara. He was informed that Asran, a country which borders on the west of Bornou, abounded so much in silver, that the natives construct their defensive armour of this metal, as well as the corslets of their horses. 


\section{CHAPTER VIII.}

FURTHER PROCEEDINGS OF THE AFRICAN ASSOCIATION.

Horneman.-His Departure from Cairo._Journey through the Desert._Siwah._Remains of Ammon._Augila._Fezzan.-The Tibbo and Tuarick.-Interior of Africa.Nicholls._Roentgen._I'Hagi Mahommed._Jackson.

Freidric Horneman, the son of a deceased clergyman, was educated at Göttingen, where he studied divinity. In the summer of 1795 , he requested Dr Blumenbach, Professor of Natural History in that University, to recommend him to the African Association in London; informing him, that it had long been his most sanguine desire to explore the interior of Africa; that he had consulted every authentic source of information on the subject, and directed his studies to this object. From the replies which he gave to various objections stated by the professor, in order to discover if this resolution was the consequence of mature deliberation, and from the result of the private inquiries instituted with respect to his character, Dr Blumenbach was induced to comply with this desire. In his letter to Sir Joseph Banks, he in- 
formed the Association, that, to an excellent constitution, $\mathrm{Mr}$ Horneman united great and respectable literary attainments, and a considerable knowledge of mechanics, both theoretical and practical ; that he was patient of fatigue; in his form stout and athletic; in his habits temperate and abstemious; in his disposition cheerful and full of vivacity; and that, excepting the usual diseases of infancy, he had known sickness only by name. To this letter Sir Joseph Banks answered, "If Mr " Horneman be really the person you describe, he " is the very identical person whom we are in " search of." This reply was communicated to Horneman, at Hanover, by the professor, who, to his astonishment, saw him enter his apartment, before he imagined the letter could have reached him; such expedition had the young adventurer used in travelling from that city on foot. In the course of one night, he formed an excellent plan of his journey, which was immediately dispatched to London, for the inspection of the Association. The summer of 1796 was employed in attending the lectures on natural history at Göttingen, and in acquiring Arabic and the other oriental languages. In February $179 \%$, he visited London, and was introduced to the African Association, who unanimously sanctioned his appointment. After a passport had been procured from the French Directory, Mr Horneman proceeded to Paris, VOL. I. pd 
where he was introduced to some of the most eminent literary characters of the National Institute, who received him with great attention, and zealously promoted his views. From Paris, Mr Horneman proceeded to Marseilles, where he embarked in a Cyprus trader, and; after a voyage of twenty days, arrived, on August 31st, at Lernica in Cyprus. From Lernica he passed to the bay of Caroubè, where he arrived on September 10th. At Alexandria, he resided ten days in the house of the English consul, the greater part of which was employed in mineralogical researches in its vicinity. In one of the convents, he met, by uncommon good fortune, an aged monk, a native of Germany, who spoke Arabic more fluenitly than his native language, and who was going immediately to Cairo, where he intended to reside for some months. In company with this friendly monk, he proceeded to Cairo to wait for the departure of the Cassina caravan, and arrived on September 27th. He spent some months in acquiring the language of the Mograbins, or Western Arabs, and was then detained some time longer, by the breaking out of the plague. Lastly, when he was on the point of departing, news arrived that the French, under Buonaparte, had landed at Alexandria. All Europeans were then seized and confined in the castle, chiefly to save them from the fury of the populace. They continued there till the arrival of 
Buonaparte, who no sooner learned the situation and destination of Horneman, than he sent for him, supplied him with passports, and made liberal offers of money, or whatever else might be necessary for his progress.

Horneman set out with the caravan, on the 5th of September 1799, from the neighbourhood of Cairo, and on the 8th entered the Libyan desert. In this journey, the Arabs travelled the whole day, without stopping either for rest or for meals. In the evening they halted, made asmall hole in the sand, and, having collected some wood, kindled a fire to cook their victuals. These consisted chiefly of flour, kouskous, onions, mutton suet, and oil or butter, which are boiled together, and made into different species of soups or puddings. Each cooked his own victuals, and Horneman soon found, that, by employing the services of another, he exposed himself to contempt or suspicion; he followed, therefore, the example of the rest.

The surface of the sandy waste over which they travelled, precisely resembled a shore from which the waters have retired after a storm. It was covered with innumerable fragments of petrified wood, sometimes whole trunks of trees, twelve feet in circumference, sometimes merely branches and twigs, or even pieces of bark. Fragments of masts have been supposed to be discovered; but these are sonceived to have been merely broken trunks of an 
elongated form. This petrified wood was generally black, but sometimes lightish grey, when it resembled natural wood so completely, as to be sometimes brought in for the purpose of firing.

After a journey of eleven days, the party arrived, on the 15th September, at a small village situated on a rock, called Ummesogeir. This rock, sequestered by such immense deserts from the rest of the world, contains only about 120 inhabitants. They are hospitable, simple, and peaceable; and subsist by collecting dates, which are sold to the Arabs, and sometimes carried to Alexandria. Orice only, it is said, a party of Bedouin Arabs attempted to strip them of their little domain; but they were driven off; and the inhabitants ascribe their success to the miraculous influence of one of their holy men.

From Ummesogeir, a journey of twenty-four hours brought them to Siwah, an extensive oasis, containing the only considerable mass of population which occurs on the route to Fezzan. Siwah is built upon and around a mass of rock, which, according to tradition, was hollowed out into caves, for the abode of the ancient inhabitants. The houses, in fact, bear still a resemblance to caves, and are huddled together so close, and in such confusion, that many of them want light, and the whole forms a labyrinth, through which no stranger can penetrate without a guide. It was compared 
to a bee-hive; and the general aspect, the crowded population, and the confused hum which issued from its precincts, all tended to justify the comparison.

Siwah is situated in a well watered valley of about fifty miles in circuit, hemmed in on every side by barren rocks. Browne gives a much smaller extent, but probably referred only to the immediate neighbourhood of the town. The soil is a sandy loam, producing corn, oil, and vegetables; but dates form the chief product and wealth of the district. Baskets of dates are the standard by which all commodities are valued. Almost every Siwahan possesses a date garden, well enclosed, and carefully watered. Mr Horneman was unable to form any precise estimate of the population. The government was originally vested in twelve shieks, on whom the executive government devolved in rotation; but twenty other wealthy citizens having forced their way into power, it has become a very turbulent aristocracy. Matters of importance are debated in the council of the chiefs, which is held close to the town wall; and when they are unable to come to an amicable decision, recourse is speedily had to arms. Our traveller gives no favourable report of the inhabitants. They were forward and insolent; and, to place their goods in security, the travellers required much stricter precautions than they had hitherto been accustom- 
ed to employ. The language appears to be aboriginal, and to be a dialect of that spoken by all the native tribes in this part of Africa.

Siwah is particularly remarkable for a monument of antiquity situated a few miles to the westward. This, which, by the natives, is called Ummebeda, consists of a large mass of ruins in such a state of dilapidation, as to make it difficult to discover the original purpose for which the structure was destined. There are evident remains of an exterior wall of great strength, and about 300 yards in circumference. In the centre are found the ruins of what appears to have been the principal edifice. It is about twenty-seven feet in height, twenty-four in width, and ten or twelve paces in length. The walls are six feet thick, and constructed, particularly in the roof, of very large blocks of stone, cemented with small stones and lime. The interior of the walls is decorated with hieroglyphics, and appear to have been partly painted. From the whole description, compared with that of Browne, and with the ancient writers, there seems very little doubt, that this is the celebrated shrine of Jupiter Ammon, the object of unbounded veneration in the ancient world. The vicinity of the fertile oasis of Siwah, and the catacombs found in the neighbouring mountains, strongly tend to support this opinion.

On leaving Siwah, the road was for some time 
bordered by vast precipices, composed of a rock which appears, by the description, to be shell limestone. It was in some parts absolutely crowded with shells and remains of marine animals. Arriving in four days at the fruitful valley of Schiacha, they were suddenly interrupted by the braying of some hundred asses, which proved to be conveying the inhabitants of Siwah, armed and prepared for combat. The caravan was in a state of considerable alarm, though the scouts soon brought assurances, that no harm was intended against them. Horneman sent his interpreter to collect intelligence, and soon saw him return with a very doleful countenance. It had transpired at Siwah that they were Christians; and the sole object of the expedition was to insist that they should be seized, and immediately put to death. The interpreter was in a state of the utmost dismay, and considered his fate as inevitable; but Horneman walked firmly up to meet this tumultuous assemblage. The cry immediately arose, that these were the new Christians from Cairo (the French), and that they were traversing the country as spies. On this difficult occasion, Horneman acted his part with great courage. Besides meeting the statement of the Siwahans by the most positive averments to the contrary, he drew out a copy of the Koran, and displayed his skill in reading and interpreting that sacred standard of the Musul. 
man's faith. A deep impression was thus made on the assembly; his own caravan eagerly espoused his cause; several of the Siwahans joined; so that those who were most eagerly bent on plundering him, were at last obliged to desist. Unfortunately the interpreter, during his first panic, had removed the mineral specimens, books, papers, and other suspicious articles, and caused them to be buried in a neighbouring swamp, whence they could never afterwards be recovered.

Our traveller, having thus established his reputation as an orthodox Musulman, left Schiacha along with the caravan, and in a few days arrived at $\mathrm{Au}$ gila. This is a very ancient town, being mentioned under the same name by Herodotus. Antiquity is a general character of the towns in this part of Africa, since an immense track usually contains. only one spot fit for cultivation; on which spot the town must remain, in spite of every revolution. Augila does not present any other interesting feature. It is ill built, the streets narrow and dirty, the houses of one story only, and without any light, unless from the door. The inhabitants are chiefly employed in the caravan traffic, and display that mean and shuffling spirit, which the habits of petty trade are apt to generate.

Leaving Augila, the party came in four days to a mountain called the Neddeck, diversified by peculiarly wild and abrupt forms of rock. In three 
days more they arrived at the Black Harutch, a long range of dreary mountains, the Mons Ater of the ancients, and whose aspect entirely corresponds to this name. For six days they continued to pass through range after range, the track lying through narrow valleys, or rather ravines, often steep, and obstructed by loose stones. Whenever our traveller, from curiosity, went a little out of the road, he found the ravines still narrower, and the aspect of nature more dreary and terrific. On emerging from this mournful region, they came to a vast plain, called the White Harutch. It is chiefly distinguished by the rocks and stones having all the appearance of being glazed. It abounds in the remains of marine animals, and in shells, which, when broken, exhibit a vitreous fracture.

On the sixteenth day after leaving Augila, the earavan arrived at Temissa, situated within the territory of Fezzan. The toils and dangers of their journey were now over, and both here and at Zuila they were received with rapturous demonstrations of joy. Zuila is a considerable town, containing many rich merchants. It was said to have been aneiently the capiaal of Fezzan; and the ruins, as well as a great part of its circuit unoccupied, seemed to bear testimony that it had once been more considerable than at present. In a short time they arrived at Mourzouk, the capital, which terminated their tedious journey of seventy-four days. The 
Sultan, according to his usual custom on the arrival of a caravan, was posted on a rising ground in front of the city. He was seated in an old elbow chair, covered with a cloth striped red and green. Each traveller then pulled off his slippers, and approaching barefoot, kissed the royal hand, then went and seated himself behind. The pilgrims raised a chaunt of gratitude, for their prosperous journey, which was continued till they were dismissed by the Sultan, who sent afterwards a present of dates and meat to each of the tents.

Fezzan, according to Horneman, is about 300 miles in the greatest length of its cultivated part, and $200 \mathrm{in}$ its greatest breadth. The climate is not agreeable ; in summer, insupportably hot; in winter, often extremely cold. It seldom rains, and there is not a river, or even rivulet, which deserves the name. Dates are the staple product of the soil ; though fit for grain, it does not, from the defect of cultivation, produce sufficient for the consumption of the inhabitants. Little attention is paid to the rearing of animals. The ass and goat are the most numerous. The population is not supposed to exceed 70,000 or 75,000 inhabitants. Manufactures are in the rudest state; nor does the country contain a good artificer of any description. The commerce is, however, considerable; but chiefly of transit, in consequence of the central sitation of Fezzan. It forms the medium of com- 
munication between Egypt and Marocco, between Barbary and Nigritia. From October to February Mourzouk is a species of rendezvous for merchants from every part of Africa. This trade, however, is rather carried on by the tribes immediately bordering on Fezzan, the Tibbo, Tuarick, the people of Augila, and Cashna, than by the inhabitants of Fezzan itself. The king, though tributary to Tripoli, is entirely absolute within his own territory; and the taxes are often levied in a very arbitrary and oppressive manner. The people of Fezzan are abstemious in regard to food, but are much addicted to drunkenness, and their manners in other respects extremely licentious. They universally profess the Mahometan religion.

$\mathrm{Mr}$ Horneman obtained considerable information concerning the tribes, who fill the habitable portions of the vast desert which intervenes between Fezzan, Bornou, and Cashna. These consist of two classes of nations, called the Tibbo and the Tuarick. The Tibbo extend along the southern frontier of Fezzan, thence eastward toward Egypt, and along the north of Bornou. They are small in stature, are almost, but not quite black, and have long hair, less curled than that of the negroes. They have quick eyes, thick lips, a small turned up nose, and limbs well-formed. They profess the Mahometan religion, but are by no means rigorous in its observance. They are ac- 
cused of being suspicious and treacherous; the Fezzanians shun in general to travel along with them. Their usual clothing is sheep-skins; but the principal people, when they come to Fezzan, dress themselves in large blue shirts, wrapping their head in dark blue cloth, so that their eyes only are seen. Their language is spoken with uncommon rapidity, and abounds with the consonants $l$ and $s$, so that it has been compared, both by the ancients and moderns, to the whistling of birds. The principal tribes are the Tibbo of Bilma; the Tibbo Rschade, or Rock Tibbo; and the Tibbo of Burgu. The first of these carry on most of the trade between Fezzan and Bornou.

The Tuarick extend west and south of the Tibbo, along the western frontier of Bornou, and reach as far as the Niger, along the shores of which river they are established in great numbers. Of all the indigenous tribes of North Africa, they appear to be by much the most numerous and powerful. They are divided into various nations, differing both as to manners and external appearance, but all speaking the same language. The most powerful, the Kolluvi, have made themselves masters of Asben, which ranks next to Bornou, among the kingdoms of interior Africa. Most of the trade between Fezzan and the countries on the Niger is carried on by this people. They are thin, rather tall; their step is at once steady and. 
swift; their look is stern, and their whole demeanour warlike. Their dress consists of a short shirt and breeches, both of a dark blue colour, and they wind a black cloth round their head like a helmet, which covers all except their eyes. Most of them are black, though without the negro features; but the tribe called Tagama, situated on the Niger, is at least comparatively white. This tribe differs also from the rest of the race in not being Mahommedans. They were described to Horneman as Nazari, being the term by which, in Africa, Christians are usually designated. He asserts, however, that he found the term applied generally to infidels, not to Christians only, but to Pagans; in which last sense he conceives it to attach to these Tuarick. This, however, is evidently the same report which was collected, by Jackson and Park, respecting a Christian nation situated on the Niger.

Horneman did not gain much information respecting Tombuctoo, between which city and Fezzan there is little communication. Houssa, called by him Haussa, is represented, not as a single kingdom, but as a general name applied to the whole track situated along the eastern part of the Niger. It comprehends, according to him, Cashna, Daura, Cano, (probably the ancient Gana,) Solan, Noro, Nyffe, Cabi, Zamfara, and Guber. Most of these kingdoms are tributary, either to Bornou or As- 
ben. The Haussa, though negroes, are not quite black, and have an interesting countenance. They are the most intelligent people in the interior of Africa. Mild, benevolent, and extremely gay in their manners, they cultivate the land with great assiduity, and excel in the manufacture of cotton cloth, with which they supply the Fezzanians. The Haussa women are described as possessing a species of music which has the power, either of melting their husbands to tears, or of rousing them to warlike achievements.

Bornou is at present decidedly the most powerful kingdom in the interior of Africa. Cauga and Wangara are governed by officers appointed by the Sultan; Begarmee, Cashna, and almost all the states composing Haussa, pay tribute to him. The Bornouans are blacker than the inhabitants of Haussa ; they are also ruder in their habits and manners. A kingdom situated round a large lake was described to Horneman under the names of Cougu, Lussi, and Fiddri, (Fittri of Browne, and Cauga of the Arabians.) The lake is four miles in circumference during the dry season, but is increased by the rains to double that magnitude. The natives dwell in huts, and are in a very low state of civilization. To the east lies Begarmee, famous for its slave trade, or rather slave stealing. Still further east lie Wadey and Metho, (the same probably with the Bergao of Browne,) and beyond them Darfụr. 
With regard to the river explored by Park, and which Europeans call the Niger, Mr Horneman's information is, that it flowed from Tombuctoo eastward through the kingdoms of Haussa, particularly Nyffe and (abi, where it is called Gulbi, (the same as Joliba); it then passed through part of Bornou, whence it turned suddenly southwards, and, passing along the southern frontier of Darfür, Howed on to Sennaar, being the same stream with the Bahr-el-Abiad, or Egyptian Nile. One person, however, assured him, that the communication took place only during the wet season, and that at other times the Nile was reposing, or non fuens.

After some stay at Fezzan, Mr Horneman made an excursion to Tripoli, whence he returned to Fezzan on the 29th January 1800. On the 6th April, he writes on the point of setting out with the caravan for Bornou, along with two great Shereefs, whose protection he considers as placing him in full security. No intelligence being received from him during that and the two following years, very serious despondence began to arise. On the 17th January 1804, the Altona Gazette stated, that, in September 1803, Mr Nissen, the Danish consul at Tripoli, saw there a merchant of Fezzan, lately arrived by the caravan, and inquiring of him after Jussuph, the name under which Horneman travelled, the merchant replied, that Jussuph was 
was gone to Gondasch, with the view of thence proceeding to the coast and returning to Europe. It was elsewhere stated, that the merchant had come from Buran. Neither Gondasch nor Buran had ever been heard of in Europe; but the cities of the interior are too little known to make this a subject of wonder; nor is it easy to say, in passing through so many hands, what transformation the sounds of an unknown language may undergo. In the Report of June 1, 1805, Sir William Young states, that $\mathrm{Mr} M{ }^{\prime}$ Donogh, long consul at Tripoli, had mentioned to himself " having, while at Tripoli, " received accounts from a very respectable Moorish " merchant, that Jussuph, or Horneman, had been "well at Cas'na about the month of June 1803, and "that he was there highly respected as a Marabout " or Musulman saint." No other precise information was ever obtained respecting this traveller; though, on the 28th May 1808, the committee report, that they are " not without some gleam of hope, found" ed on some uncertain reports, that he may still "be in safety;" and, on the 27 th May 1809, add, "Some few circumstances relating to your " traveller, Mr Horneman, have been laid before " your committee, but of so vague and uncertain a " nature, as to afford no great hope of a successful " termination of his important undertaking, but at " the same time, not so absolutely unfavourable as " to extinguish every hope of his return to his friends 
" and to his country." After the lapse, however, of seventeen years, every such expectation must be considered as finally closed.

As suon as the Association began to feel despondence as to the return of Horneman, they looked round for some one to fill his place in the arduous task of exploring interior Africa. Two gentlemen offered their services, Mr Fitzgerald and $\mathrm{Mr} \mathrm{Ni}$ cholls ; but the former limited his proposal to the country bordering on the Cape of Good Hope, which was considered an object of inferior interest. Mr Nicholls fixing no such limitation, and appearing well qualified for the undertaking, his services were engaged by the committee. The point fixed for his outset was Calabar, in the Gulf of Benin, by proceeding directly south from whence he would reach, by a route shorter than any other, the heart of the unknown region on the Niger. Sir William Young, in his report, states, what has recently been confirmed, that the native merchants in that part of Africa were in habits of frequent communication with the country of Houssa. Mr Nicholls, therefore, having obtained recommendations from the principal traders in Liverpool, sailed from that place on the 1st November 1804, and arrived at Calabar in the January following. Several letters were received from him, by which it appeared, that he was well received by the chiefs and principal traders. He did not gain much information about

VOL. I.

E e 
the interior, as most of the slaves came from the west, and the Howatt country, through which he meant to travel, traded with Calabar only for yams. They had not been able to ascend the river of $\mathrm{Ca}$ labar very high, as, after sailing a certain distance, they came to an immense fall of water, which was heard for several miles; after passing which, the land rose very rapidly.

From these circumstances, very sanguine hopes were entertained from the mission of $\mathrm{Mr}$ Nicholls; but these were wholly extinguished by the next accounts, which stated, that he had been seized with the fever of the country, and had fallen a victim to it.

The next person chosen by the Association was a young German, recommended by Professor Blumenbach. In their Report of 28th May 1808, they withhold his name, lest the knowledge of it should prove injurious to the plan upon which his mission was to be conducted; but it has since been understood to have been Roentgen. He is described as well born; as adding, to an upright and unblemished character, strength of mind, and a vigorous constitution, great ardour in the pursuit of knowledge, and a most anxious wish to promote the objects of the Association. He proceeded upon Horneman's plan of passing for a Mahommedan; made himself master of Arabic ; was circumcised, and adopted entirely the costume and manners of 
the East. Early in 1809, he arrived at Mogadore, and, after spending some time in fitting himself for the part he was to act, set out, with two guides, to join the Soudan caravan. Soon after, his dead body was found at a little distance from Mogadore. Nothing further was ever ascertained; but the probable conjecture is, that he was murdered by his guides, with the view of possessing themselves of the property which he carried along with him. Such was the fatal termination of this new effort to explore Africa.

In the course of this period, some information, collected from native sources, was transmitted to the Association. Mr Cahill from Rabat, sent the report of l'Hagi Mahommed, resident at the Well of Aroan, a station on the road to Tom. buctoo. He states, that, about three years before, the king of Bambarra had conquered Tombuctoo, and had established there a negro government, though he permitted the Moors still to reside and carry on their trade. He adds, that he himself had met Park at Sansanding, and offered to conduct him to Tombuctoo, whither he might have gone in perfect safety. He confirmed every other part of that traveller's statement, with regard to his own adventures, and the course of the Niger as far as Tombuctoo. The route from Cabra, the port of Tombuctoo, to Butoo, the port of Houssa and Cashna, is given by him, though on report: 
only, as follows. From Cabra to Agadez, a scattered negro town, the houses built with reeds and rushes, eight days; thence to Humbri, fifteen days ; from Humbri to Butoo, twenty or twentyfive days. Eastward of Butoo, the navigation of the river is interrupted by falls and cataracts, and little known; but it is generally believed to be the Nile, or to fall into it.

On the 17th November 1804, Mr Grey Jackson, who had resided many years as a merchant at Mogadore, made a communication to Sir Joseph Banks, relative to Tombuctoo, derived from the information of persons who had visited or resided in that city. He declined mentioning their names, lest, in case of his return to Mogadore, he should be found to have committed himself by doing so. The substance of this letter was afterwards published, in an expanded form, as an appendix to Mr Jackson's description of the empire of Morocco. The information has evidently been collected somewhat loosely, but it appears original, and is probably correct in many of its features.

Tombuctoo is situated on a plain surrounded by sandy eminences. It is twelve miles in circumference, but not surrounded by walls. The houses are spacious, and built in a quadrangular form, but have no upper rooms, and even no windows, being entirely lighted from the doors, which are wide and lofty. Ten miles to the south lies Cabra, the port 
of Tombuctoo, situated upon the Nile Abide, or Nile of the Negroes, which is here as broad as the Thames at London. It passes on to Houssa, 1000 miles to the eastward, and with which a considerable trade is carried on. Fifteen days' journey to the east of Tombuctoo, is an immense lake called the Sea of Soudan, the shores of which are inhabited by a race of men who are white and Christians, and who trade in larger vessels than are used upon the river. They are probably the Tagama Tuaricle of Horneman. Tombuctoo is described by Mr Jackson as subject to Bambarra, but the internal police of the city to be in the hands of the Moors. All religions are tolerated, except the Jewish. The profits on the trade to Tombuctoo were said to be so great, that 5000 dollars invested in European produce at Mogadore or Fez, would in a year or two produce a return of 20,000 . 


\section{CHAPTER IX.}

MR PARK'S SECOND JOURNEY.

Plan of a new Expedition to the Niger.-Undertaken by $M_{r}$ Park.- His arrival at Goree.-Departure.-Beginning of the rainy season.-Alarming sickness.-Washing for gold. -Depredations of the Natives.-Arrival on the Niger.Intervierv with Mansong's Prime Minister._Residence at Sansanding.-Builds a boat, and sets sail.-Reports of his death.-Particulars, as narrated by Amadi Fatouma.

- Splendid as the first discoveries of Park had been, they had tended rather to excite than to gratify the ardent curiosity by which his mission had been prompted. The Niger had been viewed by European eyes, and the direction of its stream fully ascertained. But this direction, stretching from the ocean, and into the unknown depths of interior Africa, only tended to envelope in still deeper mystery the progress of that celebrated stream. All, besides, which Park observed or learned, respecting the nations which extended along its banks, was calculated to heighten the interest with which they had always been viewed. These feelings were now become general through 
the nation, and their influence was felt in a quarter whence more powerful exertions could issue, than from the most powerful association of individuals. The present reign had been distinguished by an extraordinary zeal for promoting the progress of discovery both by sea and land; and during its lapse, Britain had risen to the first rank in this distinguished career. The same patronage under which Captain Cook had displayed himself as the first of maritime explorers, was now extended to one, who held a place equally eminent among land travellers. In October 1801, Park was apprised that it was the intention of Government to send a new expedition, on a large scale, to Africa, and was invited to place himself at its head. In his ardent mind, neither the recollection of former " hairbreadth 'scapes," nor domestic ties recently formed, could for a moment damp the enthusiasm with which he embarked in this new field of adventure. He would have departed without delay, had not a change of ministry, and some official difficulties, retarded the equipment of the expedition till September 1804. On the sth of October, he delivered to the Colonial Office a memoir on the plan and objects of this expedition. To understand these, it may be necessary to advert to some circumstances by which his views on this subject had been powerfully affected. During 
his retirement in Scotland, he had formed an intimate acquaintance with a $\mathrm{Mr}$ Maxwell, who, as a trader, had frequented the coast of Congo, and particularly the mouth of the river which bears the name of that kingdom; a grand natural feature, which, from the little intercourse maintained with this part of Africa, had been nearly forgotten in Europe. As the two friends compared their remarks on the rivers which had come respectively under their observation, of one of which, the termination-of the other, the source,-was unknown; the hypothesis very naturally arose, that those two might be one only ; that the Niger, after a circuitous course through central Africa, might, by the channel of the Congo, discharge its waters into the Atlantic. Neither Park nor Maxwell were men of speculation; but when such characters do speculate, it is always with a confidence and enthusiasm unknown to those to whom such an operation of mind is familiar. The idea was soon ripened in the mind of Park, into the fullest and firmest conviction; and, with reference to it, the whole plan of his expedition was arranged. He proposed to proceed into Bambarra by nearly his former route; there to construct two boats 40 feet long, 8 feet broad, and drawing $2 \frac{1}{2}$ feet of water. With these vessels he was to navigate downwards into Wangara; and, as he hoped, thence onward to Congo. 
He admitted, that, if the Niger should have an inland termination, his return would be extremely difficult, and even next to impossible; the only chance of success being by the Gulf of Guinea ; but he appears to have laboured under very small apprehensions of such a disappointment. He demanded, as requisite for carrying his views into effect, thirtysix Europeans, six of whom should be artificers, and the rest soldiers; asses for conveying the baggage; tools for constructing the boats ; and a variety of articles for trade and presents to the natives. His views were met by Government with the utmost liberality; the governor of Goree was instructed to supply him with the number of soldiers required; a command of money was given to the extent of five thousand pounds, and a liberal remuneration was secured, as a just reward for the accomplishment of this great undertaking.

Mr Park arrived at Goree on the 28th May. The selection of the persons who were to accompany him, and all the various preliminary arrangements, could not be completed in less than a month, and it was the 27 th of April before he was able to set out from Kayee, a village near Pisania. It was then certainly a subject of very serious consideration, whether he ought not to have delayed his journey till the close of the rainy season; and to us, who can coolly consider the question, such ap- 
pears doubtless to have been the most prudent course. Yet the censure of Park for not adopting it has perhaps been carried too far. We allude not merely to the reluctance with which, in a state of mind so exalted and enthusiastic, he could resolve to suspend all his operations, and linger for six months on the shores of the Gambia; but in fact he calculated, and upon very plausible grounds, that he might reach the Niger by the middle of June, the mere commencement of the rainy season. He foresaw not the casualties by which his progress would be impeded, and probably was not aware of the frequency and fatal effects of the previous tornadoes, no mention of which occurs in his first journey. On arriving at Pisania, it was found necessary to purchase a few additional asses, which, along with other arrangements, detained him for six days. He left Pisania on the 4th May, and arrived at Jindey on the 5th. Here he observed the process used for dyeing cotton cloths, of which there was a large manufactory. A ley is formed by filtrating water through the wood ashes of two species of Mimossa; which is then poured into a pot, about a quarter filled with indigo leaves. After being frequently stirred, in the course of ten cays, it affords the dye required. The operation is performed without any mordant, by merely dipping the cloth repeatedly in the liquid, and hanging it 
up to dry. In four days a blue colour is produced, equal to the finest India baft.

On the 11th, Park reached Madina, capital of the kingdom of Woolli. Great difficulty was here experienced, in satisfying the king as to the amount of presents to be given to him. Passing through Bambakoo, they reached on the 13th the village of Kanipe. Here the women having learned that the party were obliged to pay for water at Madina, had contrived an expedient, with the view of extorting, on the same footing, some ornaments for their persons. With indefatigable industry, they emptied all the wells in the village, and were found, when the party arrived, drawing up the water from each as fast as it collected. Park, however, by a stratagem, succeeded in securing the produce of the principal well; which, being sufficient for the supply of the soldiers, rendered all these efforts of the African ladies of no avail.

About four miles after, they entered the woods of Simbani. A civil war, now raging in Bondou, rendered it necessary to proceed with great caution, as the plunder of the Europeans might, to either party, have appeared a very profitable diversion of their force. On emerging from these woods, they had a view of the Gambia, which was here a hundred yards broad, and had a regular tide, contrary to what was usually supposed to take place above Barsaconda. At Tambico, a violent altercation 
arose, the Faramba having seized, first the guide's horse, then himself, and severely flogged him. This happened in the evening, and $\mathrm{Mr}$ Park remained all night in suspense how to act. He could have burned the village; but he delayed so violent a proceeding, till it appeared whether an amicable arrangement could not be made. In the morning, accordingly, the Faramba, seeing that our traveller remained firm, sent back the guide, and, on receiving a few presents, agreed to allow the party to pass without molestation.

On the 25th, the expedition entered the Tenda wilderness. In their march through it, some of the people unfortunately disturbed a large swarm of bees; which, issuing forth, put the whole party completely to the rout. The asses, galloping up a valley, escaped nearly unhurt; but the men and the other animals, though flying in all directions, were unable to escape most severe injury from these assailants. The fire being neglected in this confusion, spread, and threatened to consume the baggage; so that, for half an hour, the expedition appeared terminated, by this assault of the bees. In the evening, the party began to rally, and next day they were able to proceed; but the stings of the animals, besides grievously afflicting their whole number, actually caused the death of several of the cattle.

The travellers successively passed Sibikillin, 
Badoo, and Tambacunda. They saw at a distance the hills of Foota Jallo, between which, and a castellated mountain, called Muianta, the Gambia was seen descending. This river is called by the natives the Ba Deema. The travellers proceeded by Julifunda and Baniserlie, and on the 8th crossed the Faleme. On the same day they experienced, for the first time, a tornado, or storm of violent rain, accompanied with thunder and lightning, which proved for them the beginning of sorrows. In three days twelve men were on the sick list, and the ground being covered with water to the depth of three inches, left no hope but of augmented distress. The immediate effect of these storms was to produce an almost irresistible propensity to sleep, and to make it impossible for them to refrain from lying down on the wet bundles, or even on the ground.

At Shrondo, Mr Park obtained an opportunity of seeing the process of washing for gold. A woman went with him to a meadow, where there were about thirty pits, similar to those described in treating of Bambouk. Beside them were lying heaps of sand and gravel, to be conveyed to the wash-pits, which were shallow, circular, and lined with clay. All the machinery required, consisted in two calabashes, one large, into which the gravel was put; the other small, employed in pouring in the water. The sand being then covered with 
water, and carefully crumbled down, was variously agitated in the calabash, till, the lighter parts being thrown out, there remained only a black substance, called gold-rust. After a little farther agitation, the grains of gold began to appear. In two pounds of gravel, there were found twenty-three particles, though some of them very sinall. The quantity of gold-rust was forty times that of the gold. The woman assured Park, we suspect with exaggeration, that they often found pieces of gold as large as the fist. The washing takes place only at the beginning and end of the rains.

From Shrondo, the travellers proceeded along the mountains of Konkodoo to Dindikoo. Here they found also a number of gold pits, sunk to the depth of about twelve feet, with notches in the sides to serve the purpose of ladders. They observed, along the banks of a rivulet, a yellow and rusty-coloured sand, in which the gold was contained. The mountains here exhibited very steep precipices, of a coarse species of red granite. They are cultivated to the summit; and the villages appeared to $\mathrm{Mr}$ Park romantic beyond any thing he had ever seen. They are built in the most delightful glens of the mountains ; and the inhabitants, while the thunder rolls in awful grandeur over their heads, can look from their tremendous precipices over all the wild and woody plain, 
which extends from the Faleme to the Black River.

The anxiety of Mr Park for the fate of the expedition, became now deeper every moment. Half of them were sick, or at least unfit for any vigorous exertion. The sick began to lie down, and refuse to proceed. Dreadful difficulty was experienced in driving the cattle up some of the rocky precipitous tracks. The natives, too, seeing the distressed situation of the party, began to avail themselves of it, by carrying off whatever was left unprotected. At a village called Serimanna, it was necessary to leave two of the men. At another called Gimbia, the people attempted, by main force, to stop and plunder them; but, on loaded muskets being presented, they were soon induced to desist, and Park very prudently gave a few presents, to induce them to treat well such of the party as might be obliged to return. Near a village called Sullo they observed a country, beautiful beyond imagination. It presented all the possible diversities of rock; sometimes towering up like ruined castles, spires, pyramids, \&c. They passed one place so like a ruined Gothic abbey, that they halted a little before they could satisfy themselves that the niches, ruined staircase, \&c., were all natural rock. They observed, also, several lofty insulated cliffs of granite. In short, the whole country between the $\mathrm{Ba}$ Fing and $\mathrm{Ba}$ Lee, two 
tributaries of the Senegal, is said to be rugged and grand beyond all power of description.

At Konkromo Mr Park had an opportunity of seeing the mode of smelting gold. The metal was put into a crucible of common red clay dried in the sun, and then fused by the application of bellows to a charcoal fire. The melted gold was then poured into a furrow, and, when cold, was hammered into a square bar. After being again heated, it was twisted, by two pairs of pincers, into the form of a ring.

The party crossed with difficulty the Ba Fing, which is here a large navigable river. One of the men was drowned, in consequence of a canoe oversetting. The people here, says Mr Park, are all thieves. Scarcely a day now passed, without some one of the men either dying or being left behind. At Koeena, on the $2 d$ of July, they had an alarm from three animals whom they at first supposed to be wild boars, but who proved to be young lions. After prowling about all day, they at midnight attacked the asses, which all broke their ropes, and rushed in among the tents. One of the lions came so near, that the sentry made a cut at him with his sword; however; they did not succeed in doing any mischief.

After passing the villages of Kombandi and Fonilla, Park came to the Wonda, called also the Ba Woollima: Though swelled two feet, it was 
still fordable; but the driving over the asses was found a very nice and difficult operation. Isaaco took here a most active part; but, as he was in the midst of the stream, pushing forward six of the most refractory, a crocodile approached, seized him by the left thigh, and pulled him under water. Isaaco had the extraordinary presence of mind to search out the eye of the animal, and thrust his finger into it, which caused the monster to quit its hold. It returned to the charge, however, and seized the right thigh; but was driven off by the skilful repetition of the same manœuvre. Isaaco, however, was cruelly wounded, and placed totally out of a condition for travelling ; and Park, being unwilling to proceed without him, was detained for four days, until a cure could be effected.

On the 11th July, they reached Keminoom, or Maniakorro, which he describes as the best fortified town that had been seen in Africa. The people here were " thieves to a man ;" in "theft " and impudence" they surpassed all that had before been witnessed. The most indefatigable in this calling were the sons of the reigning monarch, thirty in number, who, considering themselves as amenable to no law, did not deign to throw any veil over their depredations. In the course of two days' residence, four great coats, a large bundle of beads, a musket, a pair of pistols, and several other articles, had disappeared. But vol. I. Ff 
the difficulty became very serious, when, on the 14th July, they resumed their journey. Nearly the whole town hung on their rear, ready to lay hold on every thing which presented itself in any exposed attitude. One snatched a bag from one of the asses ; and, while Park and Lieutenant Mártyn ran to recover it, another had taken possession of a musket. 'Two of the king's sons having come up, Mr Park, after speaking a few moments to one, was much surprised, on turning, to see the other in full flight with his own musket. He ordered $\mathrm{Mr}$ Anderson to follow and fire; but the latter, considering the high extraction of the fugitive, did not deem such a remedy prudent. Pursuit proved vain ; and, on their return, it was found that the other had chosen to appropriate our traveller's great coat.

The party now formed the determination, on no account to omit firing when any farther depredations occurred. As soon as the natives were convinced that this principle was to be acted upon, they hid themselves among the rocks, and were only seen peeping through the crevices. On the 18th, one of them appeared, and, watching his opportunity, ran off with a great coat. Mr Park pursued, fired, and wounded him in the leg. The guide urged that he should be forthwith dispatched; but our traveller, having recovered his great coat, did not choose to proceed any farther. 
On the 19th, the party came to the banks of the $\mathrm{Ba}$ Woollima, which, though only fifty or sixty feet broad, was swelled to the depth of twenty feet. The passage was, therefore, very difficult. At first, large trunks of trees were thrown across, but these were carried down by the rapidity of the stream. Then a raft was atternpted; but the party, in its sickly state, could not muster strength sufficient to float it. At length they were obliged to allow the negroes time to construct a rude bridge with large branches of trees, which served the purpose of carrying over the baggage. One man was unable to cross, and died soon after. At Mareena, the next town to which they came, the people stole five asses, but were obliged to restore them. They next came to Bangassi, a town four or five times as large, and equally well fortified, as Maniakorro. Here Park had an audience of Serenummo, the king; who, recollecting his former journey, shewed extreme surprise, tinctured ap- parently with suspicion, at the motive which could induce him again to pass through this country. Park enumerated all the circumstances, which made it improbable that he should come with any but the most laudable intentions; and concluded with the remark, that he had a few presents winch might be worthy of the acceptance of his majesty. The presents were accordingly displayed; and, though viewed with extreme apparent indifference, they 
had the effect of relieving the difficulties under which the king's mind laboured; and he no longer hesitated to grant permission to pass through his territories.

Mr Park remained three days at Bangassi, in hopes of in some degree restoring the health of the soldiers, but it became continually worse. One of them died, and it was necessary to leave another at Bangassi. Soon after their departure, on the 27th July, four men lay down, and declared themselves unable to proceed. $\mathrm{Mr}$ Park himself felt very sick and faint; and seems to have been about to give way to despondence, till coming to an eminence, he had a view of some very distant mountains to the south-east. Then, indeed, " the certainty that "the Niger washed the southern base of these " mountains made him forget his fever; and he " thought of nothing but how to climb over their " blue summits."

The party now reached Nummasoolo, formerly a large town, but having been destroyed, in a recent war, three-fourths of it were now in ruins. Here a prodigious shower came on, which not only wetted themselves completely, but threatened to destroy great part of the merchandise; and it was necessary to employ two days in drying it. They came next to Sobee, a town which had been twice destroyed in the course of the last ten years. The whole route being on the frontier between Man- 
ding, Kaarta, and Bambarra, was marked by ruined towns and villages. Here died the last of the forty asses purchased at St Jago, and which were of a much superior quality to those collected on the road. On the 6th August, after leaving a village called Koolihorri, three of the men lay down, unable to proceed, and on the 9 th one of them died. The same day they had to pass a very rapid stream, called the Ba Woolli. The baggage was easily transported, by means of a canoe; but a number of the asses had very nearly been drowned. On the 10th, $\mathrm{Mr}$. Anderson, brother-in-law to $\mathrm{Mr}$ Park, became extremely ill, and was got on with very great difficulty, both on that and the following days.

On the 12th August, as the party were proceed. ing, they heard, on their left, a noise resembling the barking of a large mastiff, but ending in a hiss, like what Mr Park calls the fuff of a cat. Another and nearer bark was soon heard, and presently a third, accompanied by a growl. A hundred yards farther, at an opening in the bushes, three lions were seen advancing towards them. They were very large, and came bounding over the long grass, following, but abreast of each other. Mr Park advanced to meet them; and, when they were at a long shot, he fired at the centre one. He did not conceive himself to have struck it; but they all stopped, looked at each other, and then bounded 
away. Mr Park, having reloaded his piece, on looking up, saw the last of them march slowly off among the bushes. Half a mile farther, he heard another growl; but they did notagain make their appearance.

Soon after, Mr Park found himself entangled in a species of ground peculiar to Africa. A stratum of stiff yellow clay is broken into fissures, fourteen or twenty feet deep, with very steep sides. About dark, Mr Park was so entangled in these horrid gullies, that he was obliged to pass the night in one of them. Separate as he was from the rest of his party, and with $\mathrm{Mr} \mathrm{An}$ derson in a high fever, this threatened to be productive of great distress. His companion, however, slept wonderfully well, and in the morning, he rejoined the others, who had spent the night in the same manner, at about half a mile's distance.

On the 15th, at a village called Dombila, MrPark met Karfa Taura, from whom he had experienced such signal kindness in his former journey. Karfa, having heard that a coffle was travelling through the country, conducted by a person of the name of Park, came from Boori, a distance of six days' journey, to meet his old friend.

After leaving Dombila, Mr Park came to a district abounding in corn, which proved very embarrassing, from the difficulty of preventing the asses from eating any portion of it. According to the law of Africa, if an ass devours a single blade, 
he may be seized; and, although he cannot be employed, may be killed and eaten; an use of his person, which, however little tempting to an European palate, appears delicious in the eye of an African.

On the 19th, at three o'clock, Mr Park reached the summit of the ridge which separates the Niger from the remote branches of the Senegal; and, coming to the brow of the hill, he once more saw the Niger rolling its immense stream along the plain.

It was impossible for Park not to be deeply struck with the contrast of his present situation, with the situation and the hopes with which he had departed from the Gambia. Of thirty-eight men who had accompanied him, seven only remained, all sick, and several in such an extremity, as scarcely to afford hopes of recovery. He admits that " the prospect " appeared somewhat gloomy." Yet his hopes and enthusiasm were still buoyant. Again to behold the Niger, and to embark on its waters, had long appeared the termination of his evils, and the fnlfilment of his highest dreams of ambition. He reflected also with satisfaction, that he had already solved an important problem in regard to African discovery. He had transported a party of Europeans, encumbered with baggage, for more than five hundred miles through the heart of Africa, without involving himself in any quarrel with the na- 
tives, and without suffering even any serious depredation. He even considered it as proved, that the journey, if undertaken in the dry season, might be performed without the loss of more than three or four men out of fifty.

On the 21st, Mr Park hired a canoe to carry the baggage to Marraboo, and on the following day embarked in it with Mr Anderson. Several rapids intervened; but the river, being swelled by the rains, was navigable over them. The Niger was here an English mile in breadth, and at the rapids, was spread out to two miles; so that it was already a much larger river than the Senegal or Gambia. The current carried them down at the rate of five knots an hour, and the oar was required only for giving the boat its proper direction. The rapids are formed by a ridge of hills, which here cross the channel of the river. There are three principal ones in the middle, and numerous smaller ones, which are easily avoided by following one of the branches that lie near the shore. Even there the velocity was such as to make our traveller sigh.

On arriving at Marraboo, Mr Park sent forward Isaaco to Sego, in order to treat for permission to pass through Bambarra, and to build a boat for his navigation down the Niger. Several days elapsed without any answer; and unfavourable rumours arose ; it was even asserted, that Mansong had with his own hand killed Isaaco, and had declared his. 
determination to follow the same course with every white man who should come into his power. All apprehensions, however, were dissipated, by the arrival of the king's " singing-man," who declared Mansong's high satisfaction with the presents which Isaaco had brought, and invited Park to Sego, to make a formal delivery of them in person. Park was eager to depart; but the Bambarran laureate being much attached to goed cheer, which was fur. nished very copiously by the Dooty of Marraboo, could not be prevailed upon to embark till the 12th. After passing Koollikorro and Yamina, Park arrived at Samee, where he met with Isaaco. A new arrangement had been made; according to which Modibinne, the prime minister, was to come to this place to receive the presents. Isaaco stated, that the king always assured him that the party should be permitted to pass, but whenever he attempted to enter into particulars, his majesty began to construct squares and triangles with his finger upon the sand; nor was it possible, during the rest of the interview, to withdraw his mind from that geometrical operation. Isaaco hence in. ferred, that he laboured under some secret dread, probably of a superstitious kind, with regard to the Europeans; especially as he had always shumned every arrangement, which could lead to a personal interview with them.

On the 22d. September, Modibinne made his 
appearance. On being introduced to Park, he intimated Mansong's wish to know the motives which had brought him to Bambarra, and proposed, that he should take till next morning to prepare his statement. The speech which Mr Park then made exhibits his judgment and address in the most advantageous light. After alluding to his former passage through Bambarra, to Mansong's generous treatment of him, and to his new journey, he added, "You all know that the white people are a trad" ing people; and that all the articles of value, "which the Moors and the people of Jinnie " bring to Sego, are made by us. If you speak of " a good gun, who made it? the rohite people. "We sell them to the Moors; the Moors bring " them to Tombuctoo, where they sell them at a " higher raie. The people of Tombuctoo sell " them to the people of Jinnie at a still higher "price, and the people of Jinnie sell them to "you." It was then easy to shew, that a direct communication with the whites would enable them to procure these articles at a much cheaper rate. Modibinne replied, "We have heard what you " have said. Your journey is a good one; and " may God prosper you in it. Mansong will pro" tect you." The presents were then exhibited, and excited the highest admiration, particularly a silver-plated tureen, and two double barrelled guns. Modibinne said, "The present was 
"great, and worthy of Mansong." He expressed, moreover, so earnest a wish to see the rest of the stores, that Park was forced to make a reluctant exhibition of them. Modibinne said there was nothing that was bad, and repaired to Sego. He returned on the $25 \mathrm{th}$, with a most favourable answer from Mansong. That monarch assured Park of protection, in travelling through his dominions in any direction. He added full permission to build his boat at Samee, Sego, Sansanding, or Jinnie. Park chose Sansanding, as affording more quiet, and as meeting the desire, which Mansong so uniformly manifested, of avoiding a personal interview.

In the voyage downwards, our traveller complains extremely of the intensity of the heat, which, at one time, appeared to him sufficient to have roasted a sirloin. On the $2 d$ of October, two of the soldiers died. He did not touch at Sego, but proceeded direct to the place of his destination.

Sansanding is a large town, said to contain eleven thousand inhabitants, and is the theatre of a very considerable trade. The market place is an extensive square, constantly crowded with people, and where the different articles are exposed on stalls shaded by mats from the heat of the sun. Each stall contains generally only one article; some beads only; some indigo in balls; others wood ashes in balls; others Houssa and Jinnie cloth; and one 
was observed with nothing but antimony in small bits. Salt, the staple of the place, has a corner of the square appropriated to it. There is also a butcher and a beer market, both well supplied. Upon the whole, the arrangements made for the convenience of trade, and the minute subdivision of labour, exhibit a maturity of commercial improvement, such as we could little have expected to find in the heart of Africa. A list is given of the prices which goods bear in this market; some of the leading articles of which may deserve to be extracted. The value is given in cowries, that species of small shells which form the general currency of interior Africa.

A musket 6000 to $\% 000$.

A cutlass 1500 to 2000 .

Amber, according to its various quality, 1000 to 60 .

An Indian baft 20,000.

Scarlet cloth, 10 spans, 20,000. in retail, 30,000 .

Paper per sheet 40.

A minkalli of gold (12s. 6d. Sterling) 3000.

Elephants' teeth, according to size, 10,000 to 3000.

A prime slave (male) 40,000. (female) 80,000 to 100,000 .

A fat cow 15,000.

A fowl 250 to 300 . 
Mansong had promised to send two canoes; but as these were long delayed, Park determined to secure the means of purchasing boats for himself. He therefore began a sale of the European goods which he had brought along with him; and as the quality and price were more eligible than was usual in this market, he had an immense run, and was obliged to employ three tellers to count his proceeds. Such a success raised the envy of all the mercantile world of Bambarra, and he was assured by Modibinne, that very high offers had been made to Mansong, if he would either kill the Europeans, or immediately send them out of the country. Greatly to his honour, Mansong positively rejected this proposal. On the 16th October, Modibinne came down with a canoe from Mansong. One half of this being found rotten, the minister sent for another half; and this also proving defective, another whole one was brought. Though it too was found liable to much exception, yet, by patching up all the three, $\mathrm{Mr}$ Park succeeded in forming a large boat, which he termed the schooner Joliba. On the 16th November, he was ready to begin his voyage.

During his residence at Sansanding, our traveller collected some intelligence respecting the countries immediately to the east. He learned that a siver, nearly half as large as the Niger, called the Ba 
Nimma, rose in the Kong mountains, and after passing one day's journey to the south of Sego, and receiving a branch from Miniana, emptied itself into the Dibbie. He was told that Jinnie lay, not upon the Niger, but at the confluence of the Nimma and Miniana. This is probably a mistake, though I have little doubt, from concurring testimonies, of that city lying at the confluence of two rivers. It was also said, that nothing was to be dreaded from the Moors, unless at Tombuctoo; the northern bank of the river at all other points being inhabited by native tribes, called the Soorka, Mahinga, and Tuarick. Accounts were álso received of a great water called the Ba Sea Feena, situated at a month's journey beyond Baedoo, and described as incomparably larger than the Dibbie.

On the 28th October, Park met with a severer blow than any he had yet experienced. His near relation and intimate friend, $\mathrm{Mr}$ Anderson, died, after an illness of four months. He modestly declines, from personal motives, any studied panegyric; but mentions him in a manner, which shews the highest estimate of his merit. "I shall only ob" serve," says he, " that no event which took place "during the journey, ever threw the smallest " gloom over my mind, till I laid Mr"Anderson in " the grave. I then felt myself as if left a second " time lonely and friendless amid the wilds of Afri"ca." The whole party was now reduced to 
five Europeans ; himself, Lieutenant Martyn, and three soldiers, one of whom was in a state of derangement. Although, however, his anticipations assumed now somewhat of a darker tint, yet his enthusiastic determination, and entire self-devotion to the cause, suffered no change. To Lord Camden he writes, "I shall set sail to the east, with "the fixed resolution to discover the termination " of the Niger, or perish in the attempt ;" and adds, "Though all the Europeans who are with me " should die, and though I were myself half dead, "I would still persevere; and, if I could not suc" ceed in the object of my journey, I would at " least die in the Niger." To Mrs Park he writes in a tone of much higher confidence; but it is impossible to say how far this may not have been prompted by the amiable wish of soothing her anxiety. To her he never intimates the slightest doubt, that his voyage was to terminate in the ocean; so that this plunging into the unknown depths of interior Africa, is called by him " set" ting his face towards England."

On the 17th November 1805, this great traveller set out on his adventurous voyage. Isaaco brought down his letters and journal to the Gambia ; but for some time no intelligence was received of himself. In the course of the year 1806, unfavourable rumours began to arrive, and these in. creasing, without any authentic intelligence to con- 
tradict them, Governor Maxwell, in concurrence with the government at home, resolved to dispatch a messenger to investigate the truth. He was so fortunate as to find Isaaco himself, who readily undertook the mission. He left Senegal in January 1810, and returned on the 1st September 1811; bringing a confirmation of all the most disastrous rumours. He had met near Sansanding with Amadi Fatouma, whom Park had engaged as his guide down the Niger to Cashna. From this person, Isaaco received a journal which contains, or professes to contain, a detailed narrative of the voyage downwarks, and the closing career of this illustrious traveller. As it relates to a subject thus peculiarly interesting, we shall transcribe the most important parts of it. The following carries it on as far as Tombuctoo. "We departed from San"sanding in a canoe the 27 th day of the moon, " and went in two days to Sellee (Silla), where $\mathrm{Mr}$ " Park ended his first voyage. Mr Park bought " a slave to help him in the navigation of the ca" noe. There was Mr Park, Martyn, three other " white men, three slaves, and myself as guide and " interpreter, nine in number, to navigate the ca" noe: without landing they bought the slave. "We went in two days to. Ginne. We gave "the chief one piece of baft and went on. In " passing Sibby (Dibbie), three canoes came after " us, armed with pikes, lances, bows, and as"rows, \&c. but no fire-arms. Being sure of their 
" hostile intentions, we ordered them to go back, " but to no effect; and were obliged to repulse " them by force. We passed Rakbara (Kabra); " here three canoes came up to stop our passage, " which we repelled by force. On passing Tom" buctoo, we were again attacked by three canoes; "which we beat off, always killing many of the " natives."

They are then described as passing by Kaffo, Gotoijege, Carmasse, and Grourmon, but without any interesting particulars as to these places. They entered then into the country of Haoussa, when Amadi represents himself to have reminded $\mathrm{Mr}$ Park that his engagement terminated here, and to have taken his leave. The narrative continues:

" Next day (Saturday) Mr Park departed, and "Amadi slept in the village (Yaou"). Next morn. " ing Amadi went to the king to pay his respects " to him. On entering the house, he found two " men who came on horseback, who were sent by " the chief of Yaour. They said to the king, "We "are sent by the chief of Yaour to let you know, " that the white men went away without giving " you or him any thing; they have a great many " things with them, and we have received nothing "from them; and this Amadi Fatouma now be" fore you is a bad man, and has likewise made a "fool of you both.' The king immediately orderVOL. I.

$\mathrm{G} g$ 
" ed Amadi to be put in irons, which was accord" ingly done, and every thing he had was taken " from him ; some were for killing him, and some "for preserving his life. The next morning early; " the king sent an army to a village called Boussa, " by the river side. There is before this village " a rock across the whole breadth of the river: " One part of the rock is very high; there is a " large opening in this rock in the form of a door, " which is the only passage for the water to pass " through; and the tide current here is very " strong. Their army went and took possession " of the top of this opening. Mr Park came there " after the army had posted itself ; and he never" theless attempted to pass. The people began to " attack him, throwing lances, pikes, arrows, and " stones. Mr Park defended himself for a long " time; two of his slaves at the stern of the canoe " were killed; they threw every thing they had in " the canoe into the river, and kept firing; but " being overpowered by numbers and fatigue, and " unable to keep up the canoe against the current, " and seeing no probability of escaping, Mr Park " took hold of one of the white men, and jumped " into the water. Martyn did the same, and they "6 were drowned in the stream, in attempting to " escape. The only slave that remained in the " boat, seeing the natives persist in throwing wea" pons at the canoe without ceasing, stood up and 
"said to them,- ' Stop throwing now, you see no"thing in the canoe, and nobody but myself, " therefore cease. Take me and the canoe, but " don't kill me.' 'They tonk possession of the ca" noe and the man, and carried them to the king." Such is the only narrative which has ever reached us respecting the fate of the expedition from the time of its leaving Sansanding. Considerable doubts, and on very plausible grounds, have been started against its authenticity. Such a discus. sion, however, could possess extremely little interest, now that the long period of time which has elapsed must have extinguished almost every hope of the return of this illustrious and lamented tra veller. 


\section{CHAPTER X.}

ADAMS'S NARRATIVE.

Shipwreck of Adams.-His Journey through the Desert.Loudenny.-Arrival at Tombuctoo.-Description of that City.-Journey across the Great Desert.-Captivity among the Arabs.-Ransom.-Observations on his Account of the Political State of Tombuctoo.

Tнк deep interest which was now excited relative to every thing connected with this region of the globe, made even the humblest sources of information eagerly sought after. One occurred, which, in these circumstances, was not to be overlooked: A gentleman, connected with the African Company, received intelligence that there was, in the streets of London, an American sailor, who had been, for several years, a captive in the heart of Africa, and had even spent six months at Tombuctoo. With laudable curiosity he immediately searched out this man; he found him in a state of rays and misery, obliged, for want of lodging, to spend the night in the open strest. The answers to the questions put to him disclosed a series of adventures so extraordinary, as inspired a wish to 
examine him more minutely. Adams (for this was the sailor's name) was on the point of setting sail for his native country, and shewed at first a considerable reluctance to remain; but this was overcome by the application of powerful motives. He was afterwards repeatedly examined in the presence of persons of distinction, who took a deep interest in African affairs. The substance of his intelligence was then taken down in writing, and thrown into the form of a narrative. The arguments used by the editor, and by a very able writer in the Quarterly Review, to prove the general authenticity of these statements, are soconvincing, and have so completely satisfied the public, that it is unnecessary to repeat them here. The want of all attempt, on Adams's part, to turn his information to account, its very discrepancy with all our preconceived ideas on the subject, afford the strongest presumptions in his favour. M. Dupuis, the British Vice-Consul at Mogadore, happening fortunately to be in London, confirmed the fact of Adams's shipwreck, his release from captivity, and the correspondence of his present statements with those formerly given to himself, and also with those of other credible persons who had been at Tombuctoo. It is certainly unfortunate that this grand object of European curiosity should have been first viewed by eyes so little enlightened or curious; and that the particulars thus gleaned should rather tend to sub- 
vert all our preconceived ideas on the subject, thar to substitute any others of a satisfactory nature in their place. These facts, however, must still deserve notice in the absence of better information.

On the 17th October 1810, the American ship Charles, John Horton master; set sail from 'New York, and having touched at Gibraltar, proceeded on a trading voyage along the African coast: On the 11 th of October, when they were a little to the south of Cape Blanco, the noise of breakers was heard, and about an hour after, the ship struck. The fog was so thick that the land could not be discerned; yet all the sailors reached it by swimming... Unfortunately, at the first alarm, they had thrown overboard not only their wine and provisions, but their muskets, powder and ball; so that, whatever enemy might appear, they were totally unprovided with any means of defence. They were soon surrounded and made prisoners by thirty or forty Moors, wlio belonged to a small douar, or fishing encampment in the neighbourhood. "These Moors appeared miserably poor, having no clothès, except a rug or skin. round the waist, and a rag, by way of turban, binding the heads of the females. Their tents were composed of stuff resembling a coarse blanket, formed of goats' hair and sheep's wool interwoven; and some had no tenits at all. Their food consisted entirely of fish, which ofter 
failed through the mismanagement of their tackle; yet they rejected all offered instructions as to the mode of better employing it. It appears from M. Dupuis, that this wretched spot, called El Gazie, is often the scene of a similar catastrophe. Traders, then, from all parts of the desert, and even from Morocco, hasten thither, in hopes of obtaining articles of value in return for trifles from the ignorant plunderers. In this trade of a woreck, watches, muslins, silks, \&c. are received for dates, coarse linens, and the few other articles which are of use in this wretched mode of life; bank notes are often obtained for a mere trifle.

Soon after their captivity the crew were stripped naked, and carried along with the Moors on a journey to the east. The captain, who seems to have lost all prudence, and to have indulged in the most furious marks of impotent resentment, was killed; the rest seem to have been tolerably treated. In about forty-four days, they came to the vicinity of Soudenny, a negro village, which seems situated on the northern frontier of Bambarra. Here, concealing themselves in the hills and bushes, they seized and made slaves of all the straggling individuals who fell in their way. The people of the village, however, received notice of their haunts, and, coming out in a body of forty or fifty, surrounded and made prisoners of the whole party. After being kept four days at Soudenny, they 
were sent forward, under an escort, to Tombuctoo. On the road, several of the Moors, who attempted to escape, were put to death.

In twenty-five days they reached Tombuctoo. The Moors were thrown into prison; but Adams, being viewed as a curiosity, was taken to the palace, where he remained during his residence at Tombuctoo. He was treated with kindness, and seems to have been an object of much wonder. The queen and her attendants often sat gazing at him for hours together. Remaining thus for half a year at perfect liberty, he certainly possessed ample opportunities of observation. The following is the general result.

Tombuctoo appeared to Adams to stand upon nearly the same extent of ground as Lisbon; but as the houses are built in a very scattered manner, the population is probably not nearly so great. The habitations of the principal people were of a square form, composed of wooden cases filled with clay and sand, and having all the rooms on the ground floor. The huts of the poorer class are formed merely of the branches of trees bent in a circle, covered with a matting of the palmeto, and the whole overlaid with earth. The king's house, or palace, is built in a square of about half an acre, enclosed by a mud wall. It consists of eight small rooms on the ground floor. All merchandise', on its arrival at Tombuctoo, is brought into this en- 
closure, where it pays a duty. M. Dupuis generally confirms this, but seems of opinion that the enclosure must be much larger than Adams represents it. He says it is called the kusba, or citadel, and that not only the merchandise, but the merchants, are frequently accommodated within it. Both the king and queen were old and grey headed, the queen immensely fat. Her dress consisted of blue nankeen, edged with gold lace, and reached only a few inches below the knee. Her head dress was a blue nankeen turban, worn only on occasions of ceremony. She wore no shoes, in consequence of which, her feet appeared as hard and dry "as the hoofs of an ass." She wore besides a profusion of ornaments of very white bone, (ivory?) large ear-rings, and necklaces of gold. The king's dress was a blue nankeen frock, profusely ornamented with gold. He had about thirty armed attendants, who remained constantly by him. In walking the streets, his subjects saluted him by touching his head with their hands, and then kissing them. He, as well as all his principal officers, were negroes, and Tombuctoo appeared to Adams completely a negro city. On this fact, so remarkable and soo little expected, some observations will be made at the end of this chapter.

The natives of Tombuctoo are a vigorous and healthy race, and expose themselves, without injury, to the most intense action of the sun. They 
are violent in their quarrels, and employ, as means of offence, not only their fists, but the still less dignified practice of biting. On the whole; however, they are a good-natured people, and exceedingly gay. The favourite amusement, as in all negro states, is dancing. A large party for this purpose is generally formed once a week, and is often continued during the whole night. At first the men take the chief part; but when the females join, it ceases to be conducted with much regard to decorum. They have several species of musical instruments, rudely constructed of reeds, ostrich quills, and cocoa nut shells. They were in general very dirty, and only the king, queen, and principal people, had a change of dress about once a weék. Ivory ornaments, and gold ear-rings, were worn by all who could procure them; and no present was so highly valued. Some had rings also upon their fingers; but these appeared to be of brass, and of Moorish manufacture. The articles of furniture consist solely of earthen jars, wooden bowls, and mats made of grass (palmeto), which are used for sleeping upon.

The food at Tombuctoo consists chiefly of Guinea corn ground between two flat stones, and boiled up into a thick mess, over which goat's milk is then poured. Men, women, and children, sit round indiscriminately, and eat it with their fingers, according to the universal practice of Africa. Not 
even the king and queen possess a spoon, a knife, or a fork. . The only distinction which they enjoy, is the use of a little butter made from goat's milk, which is considered as an article of extreme delicäcy.

There are no physicians except old women, who cure external maladies by the application of simples. Some of them appeared to be upwards of a hundred years old; nor did Adams see any blind, unless from extreme age. None of the negroes apparently could either write or read, but kept their accounts by notching sticks. The only tools which they. possessed were hoes, chisels, knives, and small hatchets, with which they cut their timber; with a few other rough instruments of iron, which they procured from the Moors.

The government of the king was despotic, but apparently mild; he could call upon his subjects to take up arms, but did not consider or treat them as his slaves. The only punishment for the greatest crimes was slavery; but Adams saw only twelve condemned to it during his residence at Tombuctoo. Smaller misdemeanours were punished by beating. with a cane, seldom very severely. Adams saw no appearance of any outward form of religious worship, except something like a prayer at funerals.

The only form of marriage, among the higher ranks, consisted in the bride going to the king's 
house, whither the bridegroom repaired after sunset, and brought her home with him. Besides one principal wife, they had several inferior ones or concubines; an arrangement which was by no means productive of domestic harmony. Adams had not an opportunity of observing the ceremony of marriage among the lower orders. Among them illicit intercourse prevailed to a great extent, and was frequently accompanied by the practice of abortion. Seduction among the higher ranks, unless repaired by marriage, was punished with slavery.

The grains chiefly cultivated in the vicinity of "Tombuctoo are rice and Guinea corn. They are raised entirely with the hoe, no cattle being used in agriculture. The fruits are cocoa nuts, dates, figs, and pine-apples. The domestic animals are chiefly goats, and their flesh is the only species which is commonly eaten. There are no horses; the cows are small, and few in number. Besides the common camel, there occurs the heirie, a small and very fleet species, which will travel fifty miles a day for many days successively. It is unfit, however, for carrying burdens. Of wild animals, lions and foxes were not seen, but were heard roaring in the neighbouring mountains. Wolves and foxes are numerous, and commit great depredations. Elephants are hunted by the negroes mounted on a heirie, the swiftness of which en- 
ables them to approach and retire without danger. The flesh is etaen for food, and the teeth are of great value. Adams has somewhat committed his reputation, by asserting that an elephant which he saw killed was twenty feet high, and had four tusks. To this he has added the report of an animal about the size of a large dog, called courcoo, having an opening in its back like a pocket, in which it carries its prey. Neither of these statements are very credible; but the editor justly observes, that a personage such as Adams, reporting, at the distance of four years, what he had observed, not at all with the eye of a naturalist, could not be expected to be rigidly accurate upon every point. The courcoo he had never seen himself, but received merely the report of the negroes upon it.

The domestic birds are Guinea fowls. The wild birds are ostriches, owls, eagles, crows, green parrots, a large brown bird that lives upon fish, and several smaller birds. The river is well stored with fish.

It may be proper to bring together all the statements of Adams, relative to the interesting subject of the commerce of Tombucteo. He makes the extraordinary assertion, that there are no shops in that city. M. Dupuis informs us, that some of the Barbary traders had assured him that there were shops, others had made a report similar to Adams. It appears totally out of the question, 
that such a city should exist without some regular mode of publicly exposing goods to sale; but it is very probable that this may be done, not in shops; according to the European sense of the term, but upon booths or stalls in a public market, as appears by Park's report to be practised at Sansanding. Whether these are to be called shops or not; becomes then a mere verbal distinction.

At about 200 yards to the south-east of the town passes a river, called La Mar Zarah, about three quarters of a mile wide, and flowing, as Adams conceives, to the south-west. About two miles south of the town it passes between high mountains, where its breadth is contracted to half a mile. Some observations upon this river, and the direction in which it flows, will be introduced on a future occasion. It is navigated by canoes, composed of fig trees hollowed out, and the largest of which is ten feet long, and will not contain above three men. In the narrative, they are described merely as fishing-boats; but M. Dupuis thinks Adams described them to him as setting sail, often by ten or twerity at a time, for slaves and merchandise.

The hunting of slaves appears to be reduced to a regular system. About once a month, armed men, to the number of a hundred or more, and at one time five hundred, marched out for this purpose. They were usually absent from a week to a month, 
and sometimes brought in considerable numbers. He was told, that they came chiefly from a place called Bambarra, lying to the south and south-west of Tombuctoo. Such a kingdom does certainly exist in that direction; but it seems probable, that the slaves would be collected rather from the barbarous nations in its vicinity, than from Bambarra itself. The slaves thus procured, along with golddust, ivory, gum, cowries, ostrich feathers, and goat skins, are exchanged with the Moors for tobacco, tar, gunpowder, blue nankeens, blankets, earthen jars, and some silks. Gunpowder appeared to bear the highest value, though only as an article of curiosity; for though the king had several muskets in his possession, no use was made of them. The trade with Barbary was carried on by parties of Moors, who visited Tombuctoo during the rainy season; but Adams, who was there through the six dry months, saw only one.

Adams collected no information respecting the neighbouring countries. Besides Bambarra, he recollected that the people of Tombuctoo spoke of Mutnougo, and of a considerable place to the eastward to which they traded, called Tuarick. He had likewise heard Bondou and Mandingo often mentioned:

After a residence of six months at Tombuctoo, a party of ten Moors came to the town, and in consideration of a large quantity of tobacco, ob- 
tained the ransom of their countrymen, and of Adams along with them. About three weeks after, the whole party set out to cross the desert. They proceeded for ten days, at the rate of fifteen to eighteen miles a day, along the banks of the Mar Zarah, in the direction of east, inclining a little to the north. The country appears to have been thinly inhabited, though they occasionally saw a negro hut. Before losing sight of the river, they loaded their camels with water, and then took a northerly direction. The territory became then desolate, and they saw only parties of negro traders bringing salt from Taudeny. The soil produced shrubs, a low kind of grass like moss; and occasionally a tree. In thirteen days they arrived at Taudeny. A supply of excellent water, and the fertility which it produces, render this a valuable place of refreshment for travellers across the desert. It contains also numerous beds of salt, an article in universal demand over Soudan. These beds are from five to six feet deep, and from twenty to thirty yards in circumference. The salt, which is partly red, comes up in large lumps mixed with earth. Taudeny is a large village inliabited by Moors and negroes, who are both equally black; its neighbourhood is cultivated like that of Tombuctoo, and abounds with date and fig trees. Here the travellers remained fourteen days for refreshment. They then en- 
tered upon the desert of deserts, if we may use the expression; the depth of the Sahara; where the sandy plain stretches on every side its unvaried surface, like that of the sea. Along this they travelled twenty-nine days, without seeing a plant, a shrub, or a blade of grass, and without meeting a human being. The travellers, and especially those who had been under confinement, began to sink under so long a series of fatigue and privation. They were supported, however, by the prospect of arriving at a station where a supply of water was to be found. On reaching it, the spring was found dry ; and they had ten days to march, with a supply of less than four gallons. This, even with the loathsome addition of camel's urine, proved very inadequate; several of their number dropped down on the road, and doubtless perished. At length they arrived at Woled D'leim, a village of tents, inhabited by Moors, who, in their dress and general appearance, resembled extremely those of El Gazie. They had been reported to $M$. Dupriis as a tribe of great extent and power, inhabiting the eastern parts of the desert, wherever water was to be found. Those whom he had seen appeared an extremely fine race of men. As soon as Adams was recovered from his fatigue, he was sent out to attend their cattle ; and,-being for some time amused with hopes of liberty, was at length roundly told, that having been disappointed of other slaves, they were deter-

VOL. I.

H h 
mined to retain him in that capacity. Adams now thought himself well entitled to attempt his escape, and he succeeded in reaching a neighbouring village before his master overtook him. Adams then appealed to the chief of this village, who decided in his favour; but offered no other redress than that of making him his own slave, and obliging the former possessor to accept a small compensation. Our traveller, however, was here well treated, and his time was rendered rather too agreeable by an intrigue, in which he engaged with one of his master's wives. This being discovered, was considered a crime truly unpardonable " in a Christian who " never prayed :" and Adams considered himself very fortunate in being merely sold to another and severer master. He was now carried to Wedinoor, a town on the borders of Morocco, where, for the first time since crossing the desert, he saw houses, though built chiefly of clay. He was much surprised to meet here two of his shipwrecked companions, in the same situation with himself They were treated, however, in themost barbarous manner, and one of them was killed. Adams himself underwent a most severe martyrdom, in consequence of refusing to kiss the hands and feet of his master's son, with whom he had had a scuffle. Even after being released from irons, he was treated with every kind of contumely, and daily assured, that "his st soul would be lost, unless he became a Mahom. 
" medan." This treatment seems to have reduced him to the lowest state of depression, both of body and mind. Happily, however, at this time his situation became known to $M$. Dupuis, whose humane exertions soon procured his release, and a servant of whom accompanied him to Mogadore. In their way he saw, on the borders of Morocco, the new state of Cidi Heshem, founded by the descendant of a celebrated Moorish saint. This prince has opened an extensive trade with Soudan, and has established a market, where the produce of that region is continually exposed for sale, on such moderate terms, that the Morocco merchants find it often more advantageous to purchase them there, than to cross the desert. The country is rich and well cultivated. Cidi Heshem maintains a guard of 6000 Moors and negroes well armed, and sets even the emperor of Morocco at defince.

Adams spent some time at Mogadore with $\mathrm{M}$. Dupuis, who seems to have examined him very narrowly on the subject of his adventures, and particularly of what he had seen at Tombuctoo. He confronted him also with several of the Barbary merchants, who had been there, and who all expressed a favourable opinion as to his veracity. He soon after sailed from Tangier for Cadiz.

Before closing this chapter, it may not be improper to make some observations on the view which Adams has given of the political state of Tombuc: 
too, and in which he has differed so widely from the ideas which preceding travellers had conveyed to Europe.

In comparing Tombuctoo, as to the ground on which it stands, with Lisbon, Adams has given an idea of its extent fully equal to what we could have anticipated ; for Lisbon is perhaps equal in this respect to any city of Europe, except London and Paris. In regard to its splendour, however, and to the state of the arts, it certainly differs very widely from what we had been taught to expect. Nothing, however, could be more natural than that exaggerated reports should be spread respecting a city so situated, and that it should be viewed through that false medium in which remote and mysterious objects are always enveloped. In fact, two of the most prominent features observed by Adams, the humble materials of which the houses were constructed, and the canoes formed of a single tree, correspond exactly with the description of Leo Africanus; and which, as it cannot be supposed that Adams would draw from that source, affords a strong confirmation of the authenticity of his narrative. But the most remarkable circumstance which it exhibits is the total absence of Moorish influence, and even existence at Tombuctoo. Our readers are already aware, that Park received assurances from various quarters, that the supreme power there was entirely in the hands of 
that people. Mr Jackson, though he states the sovereign to be Negro, yet conceives the internal management and police of the city to be entirely Moorish. M. Dupuis also evidently apprehends, that there must in this respect have been some great defect of observation on the part of Adams. I confess, that, without giving up Adams's authority altogether, I cannot concur in this supposition, for the whole scope of his narrative marks a city entirely negro, in which not only Mahommedans are without influence, but from which they are entirely excluded, and are constant objects of rigour, jealousy, and suspicion. He saw no appearance of the practice of Mahommedan rites; no mosques; nor does he believe that there are any. He adds, that no Moors were allowed to enter Tombuctoo, unless in very small parties. On arriving at Taudeny, he instantly remarks the difference, and observes, that this place is inhabited by a mixture of the two nations. It is added, " From the number " of Moors, many, if not all, of whom were residents, "it appeared, that the restriction respecting them "existing at Tombuctoo did not extend to Tau" deny." Here we find what had not before been mentioned, that there was an actual prohibition against the Moors residing at Tombuctoo. The series of statements by Adams upon this subject is therefore uniform, consistent, and positive. On the other hand; Park and all other writers unani- 
mously attest, that at no distant period the Moors were numerous, and possessed of great power and influence in that city. Putting these statements together, it appears almost certain, that there must have been a recent and total revolution; a struggle for power between the Negroes and Moors, which ended in the total expulsion of the latter. Still numerous and powerful as the Moors are represented to have been, nothing could be more natural, than that they should make an effort to regain the supreme command of which they had been divested. If this failed, it would naturally follow, that they would be entirely driven out, and a system of jealous precaution adopted, such as Adams represents to be so rigidly enforced. It may perhaps be thought pushing the inference too far to conjecture, that the new state of Cidi Heshem, on the northern border of the desert, may be in a great measure composed of the refugees from Tombuctoo. Yet it seems difficult otherwise to account for so many opulent merchants taking up their abode in such a place; and nothing could be more natural in such a colony, than the establishment of a market for the commodities of Soudan.

Such a revolution, the occurrence of which, at one time or other, can scarcely, I think, admit of a doubt, would necessarily involve a diminution of the splendour and commercial importance of Tombuctoo. That these have been overrated, I an 
ready to admit; but they certainly ought to have surpassed what appeared at Sego, at Sansanding, and other cities in this part of Africa. In losing the Moors, Tombuctoo would lose the most opulent of her inhabitants, the most polished, and the most advanced in all the arts of life. The negroes are everywhere inferior in these respects; and here, having been so long the subject people, would necessarily be in a deeper state of depression. This great city, in becoming entirely negro, would contain a population more gentle and harmless indeed, but also more rude, poor, and uncivilized. 


\section{CHAPTER XI.}

RILEY'S NARRATIVL.

Shiptureck.-Captivity.-Deliverance.-Sidi Ishem.-Narrotive of Sidi Hamet.-Adventures in the Desert-CTombur. too.-Wassanah.

J AMES RiLex, master and supercargo of the brig Commerce of Hartford, sailed from New Orleans on the 24th June 1815, and arived at Gibraltar on the 9th of August. From that place he set sail on the 23d for the Cape de Verd islands. In passing the Canaries the sea began to run high, and the weather became so dark and foggy, that they could not discern their track. On the 28th, near Cape Bojador, as it afterwards proved, the vessel struck; it soon began to fill with water, and seemed every moment in danger of going to pieces. The crew, therefore, put out the long boat, and having placed on board of it the most valuable articles, reached with difficulty the shore. They were soon joined by an Arab family, consisting of a man, two wives, and five or six children. The man resembled an oran-outang rather than a human being; and the whole party pre- 
sented a compound of ugliness, misery, and ferocity. They soon began an indiscriminate plunder, which Riley did not resist, dreading that, if enraged, they might soon collect more strength. The Arabs emptied trunks, boxes, chests; they cut the beds, and amused themselves with seeing the feathers fly before the wind, valuing only the cloth. Some fine silk lace veils and handkerchiefs they wrapt round their legs, or about their heads like turbans. After this visitation the crew again turned their eyes to the boat, with difficulty got it out again to sea, and reached the wreck, which was still above water. Soon after an augmented body of Arabs made their appearance, and by friendly signs invited the captain to come on shore. He wàs so far overcome by false confidence; or the necessity of his lsituation, as to comply. The moment they discovered him to be in their power, they began to grasp him furiously, and to point their spears and daggers at every part of his body. The object of these menaces was to induce him to bring on shore his treasure, and deliver it into their hands. A large basket of dollars was accordingly sent in, which they took and divided, but immediately renewed their threats in order to extort still more. Riley then made signs to send on shore an old man, Antonio Michel, who, on his arrival, immediately attracted the attention of the savages; under cover of which diversion 
Riley succeeded in throwing himself into the sea, and regained the boat by swimming. He afterwards saw with agony the poor old man thrust dead with a spear; but assures us, that neither by himself nor his men was he considered as having incurred guilt by this mode of saving his own life, and restoring to them his services in this critical emergency.

The boat, even in its wretched state, was now their only hope; and the object was to get it out from among the breakers, and into the open sea. This, in the opinion of Riley, a miraculous interposition of providence enabled them to effect; an event happening, which, as there seems a want of the dignus vindice nodus, might probably be traced to some very simple physical cause. They made their way through the ocean in this crazy vessel, two men bailing out the water by turns. At length, on the $2 \mathrm{~d}$ of September, their stock of pro. visions and water was on the eve of being exhausted; the leaks had increased to such a degree, that the united efforts of the crew could with difficulty keep the boat from sinking; and it appeared every moment possible that the next wave might bury them in the bosom of the ocean. Riley then represented to his crew that no resource remained but to steer towards the land; that they must inevitably perish if they continued out at sea; and that, on land, they could do no more 
than perish. The mariners, with heavy hearts, admitted the force of this reasoning, and the vessel was turned towards the coast. It was the 7 th, however, before they arrived at a promontory, which they afterwards found to be Cape Barbas, a little to the north of Cape Blanco. The shore was here lined with a face of perpendicular and broken cliffs, where they in vain attempted to find an ascent. They searched for four miles along the foot of the wall of rock, and were at length obliged to spend the night on the sand. Next morning they rose somewhat refreshed, and Riley came to a spot which seemed to afford a perilous possibility of ascent. There, "clinging for life" to the loose rocks, he scrambled from steep to steep, till, by a tedious path, he at length reached the summit of the cliff. But what was his horror, when he beheld before him an immeasurable plain, "without a tree, shrub, or spear of grass, that "could give the smallest relief to expiring nature." He fell senseless to the ground, and was some time before he regained the full possession of consciousness. His companions, who were far behind, though previously warned, experienced a similar shock at the first view of this expanse of desolation. They fell to the earth, exclaiming, " "Tis enough! here we must breathe our last." Riley, however, after the first shock was over, encouraged them still to hope, and led them on along 
the top of the cliffs. As evening approached, one of them exclaimed, "A light."' This object being soon seen by all, produced an electric influence, and diffused new life and spirits through the party. Arab bondage, which had before appeared the most horrible of evils, was now, after so near a prospect of perishing, patiently submitted to. It was imprudent, however, to approach during the night, and they waited till next day, when they went up and presented themselves in a humble posture. The Arabs, on seeing them, set up a furious yell, and immediately began to contend with each other for the possession of this unexpected prey. A distribution being made by this barbarous process, they had the affliction to find that they must separate, in consequence of the division of the Arabs into two parties. For eight or ten days they proceeded S. E. into the heart of the desert, and then began to return towards the sea for want of water. $\mathrm{On}$ the 20th, two strangers arrived; Sidi Hamet, and Seid his brother, who proved to be merchants from Morocco. Sidi Hamet, on seeing the captives, shewed some huma, nity, and gave Riley and one of his companions a little water to drink, "the first good water they "had tasted, and which inspired hope, as coming "from a better country." Sidi Hamet then inquired into their story, at the relation of which he was affected even to tears, an emotion of which he 
was ashamed, saying, that " men who had beards "like him ought not to shed tears." At the intreaty of Riley, he agreed to purchase and convey him to Sweerah (Mogadore); but he was not so far blinded by humanity, as not to drive as hard a bargain as possible; assuring our traveller, that if deceived as to the ransom, he would cut his throat. On the 24th, Riley, to his infinite satisfaction, saw the price paid for himself, consisting of two blankets, one cotton covering, and a bundle of ostrich feathers. From this time his sufferings were no longer so extreme. His skin, however, was severely excoriated by riding without saddle on the hard backs of the camels, often fifty, seventy, or even a hundred miles in the day. The surface of the desert was a dead level, like the sea when unruffled by the slightest breeze. Camels, discoverable at a vast distance, were seen traversing it in every direction. At one place, near the sea shore, they came to a chain of loose sand hills, piled up like drifted snow ; " here was no path to "guide our footsteps, nor had we a compass to " direct our course, obstructed by these dreadful "barriers." The trade wind, hitherto refreshing, now blew like a tempest, and drove the sand in clouds, cutting their flesh like hailstones, and often hiding them from the view of each other. After passing these hills, they came again to the dead level of the plain. 
On the 19th October, the travellers arrived at Wedinoor, and saw with delight the long unwonted aspect of vegetable nature, green bushes and shrubs, cows, asses, and sheep feeding, and the margin of the rivulets adorned with date trees. A violent altercation, which came even to blows, now arose between the two masters, of whom Seid, a stupid and savage wretch, insisted that the eaptives should be sold to the first Arab party whom they met. Sidi Hamet prevailed; but he warned Riley that he had paid away all his money on his word alone; and that he must die if he had deceived him. Riley being furnished with a reed and some black liquor, wrote a letter, addressed to the English, French, Spanish, or American Consuls, or any Christian merchants at Mogadore. He painted to them his sufferings in lively colours, and implored them to advance the money necessary for his ransom, assuring them of reimbursement by references to respectable houses in the different commercial cities. In eight days a letter was brought; Riley's emotion was such, that he was unable to read, and handed it to one of his companions. It was found to be from $\mathrm{Mr}$ Willshire, the English consul, was couched in the most humane and sympathizing terms, and assured him that the ransom would be immediately advanced. On the 7 th November, he arrived at Mogadore, and was received with the most-generous 
kindness by $\mathrm{Mr}$ Willshire. His situation is described as truly deplorable. Several of his bones were divested, not only of flesh, but even of skin, and appeared white, like dry bones in the desert. He was reduced from 240 to 90 pounds weight; and he scarcely dares to say, that several of his companions did not weigh forty pounds. By the application of due restoratives, however, they all in time recovered.

Riley, in his route, gained some information concerning the new state of Sidi Ishem (Sidi Heshem of Adams). This chief is said to be a descendant of the formerly independent kings of Sure. He has established himself at a point between the Atlas and the sea, by which caravans cannot avoid passing; and he has fifteen thousand men under his command. The emperor of Morocco sent lately against him an army of thirty thousand men. Sidi Ishem did not attempt a direct resistance; but hovered round, harassed them continually till they were exhausted by fatigue and hunger; he then fell upon, and cut off the greater part of them. No second invasion has been attempted.

By much the most curious part of the information in this volume, however, is that contained in the Travels of Sidi Hamet. As this person resided some time in Mr. Willshire's house, he began to give an account of the events which had occur. 
red in his journey across the desert, to and beyond Tombuctoo. These appeared to Riley so curious, that he prevailed upon Sidi Hamet to give a regular narration of them, which, with the assistance of an interpreter, he took down from his diction. 'The following are the principal facts :

The first journey made by Sidi Hamet to Tombuctoo was with a caravan of three thousand camels, and eight hundred men. They proceeded along the sea coast till they came to the border of the negro territories, when they turned eastward to Tombuctoo. The desert crossed during the whole of this journey, was described by Sidi $\mathrm{Ha}$ met as resembling that over. which Riley had travelled, generally a dead level, sometimes covered by moving sand hills. At one place, they travelled for a month without finding a blade of grass; at another, for ten days the ground was as hard as the floor of a house. The caravan returned by the same route, having suffered no disaster except the loss of several hundred camels.

The next journey was far more eventful. Sidi Hamet here joined the great accumulated caravan, and went with it in the direct route across the desert. The caravan consisted of above one thoufand men and four thousand camels, about half of which belonged to Sidi Ishem. After travelling upwards of a month, they were attacked by the 
Shume, the burning blast of the desert, carrying with it clouds of sand. They were obliged to lie for two days with their faces on the ground, only lifting them occasionally to shake off the sand, and obtain breath. Three hundred never rose again, and two hundred camels also perished. A more dreadful calamity, however, awaited them. On coming to a valley called Haherah, which they depended upon for a supply of water, every well was found dry. After digging with desperation every spot where it appeared possible that water could be found, all subordination ceased; a most furious quarrel commenced, which soon ended in bloodshed. Several hundred were killed, and every species of outrage committed. To escape from this horrible scene, Sidi Hamet, with a party of his friends, set out for the south, and supported themselves by killing camels, till a thunder storm, accompanied with copious rain, relieved them from the miseries of thirst. Proceeding southwards, they came to the bank of a river called the Gozen Zair, described as about half as broad as from the town to the island of Mogadore, that is, about fifty yards.* They now travelled four days through Soudan, described as " a hilly country, but very

* There must be here some error of the press, as the distance of the island is described (p. 470-1) to be 500 yards.

VOL, I. 
"fertile." The negroes lived along the river in small towns, fenced in with walls of reed, and in houses composed of mud and cane. Finding travelling here difficult, from the woody nature of the country, they struck north, till they came again to the border of the desert, then journeying ten days eastward, they came to Tombuctoo.

Tombuctoo is described by Sidi Hamet as a large town, which appeared to him six times more populous than Mogadore. As the latter place contains 36,000 inhabitants, this would give to Tombuctoo 216,000. The population is entirely negro, and no Moor is allowed to enter, unless fifty at a time unarmed from each caravan. There is, however, a separate town divided off from the principal one by a strong partition wall, and appropriated to such Mooselmins as are allowed to remain at Tombuctoo. The city is surrounded with a strong wall, composed of stone laid in clay, with four gates, which are shut in the night time. The king's house is large, high, and composed of the same materials as the wall: There are many stone houses in the town, with shops, but most of the habitations are built of reeds. The sovereign is a very large, old, grey-headed black man, called Shegar, which means sultan, or king. "The " people of Tombuctoo do not fear and worship "God like the Mooselmins, but, like the people "of Soudan," they merely pray once in twenty" 
four hours, and only when they see the moon. A small river runs close to the town; but it is sometimes dry, and the inhabitants go for water to the great river, which lies about an hour's ride of a camel to the south.

During our traveller's residence at Tombuctoo, the Shegar, or king, sent a caravan to the city of Wassanah; and, fortunately for our information, compelled Sidi Hamet to accompany it. They came in two hours' ride to the banks of the river, called here Zolibib (Joliba of Park), which was wider than from Mogadore to the island. They proceeded along its right bank for six days, in a direction a little to the south of east. After passing a small town called Bimbinah, the river turned more to the south-eastward, "because there was a "very high mountain in sight to the eastward." They pursued their journey more to the south for fifteen days, through a hilly and woody country, when they came again to the same river. They found here a small negro town, which, though hostile, did not attempt to molest them. They saw, on the other side, two large towns and many armed negroes, also hostile, but who could not get across the river. They travelled three days southeast along the river; then spent six days in passing a ridge of mountains, along whose steep side the river flowed; they came again to its bank, and found it very narrow and full of rocks, "which 
" dashed the water dreadfully." They travelled on twelve days south-east, seeing the river nearly every day on their right hand, and passing a number of smaller streams that emptied themselves into it. They came then to a ferry of boats, composed of trees dug out hollow, and pushed on with flat pieces of wood. Travelling on for fifteen days, mostly in sight of the river, they came to the walls of the city of Wassanah. The king came out to meet and welcome them, and they were lodged in a square enclosure, where they remained two moons, exchanging their goods for slaves, gold, elephants' teeth, \&c.

The river which passes by Wassanah is called Zadi ; it flows nearly south, and is so broad that 2 man can scarcely be seen on the opposite bank. On each side is a ridge of mountains, but with an interval on both sides between them and the river. The city appeared to contain twice as many inhabitants as Tombuctoo; it was surrounded by a very large wall, built of great stones loosely piled up; a whole day was required to walk round it. The country around is highly cultivated. The houses were also built of stones without cement, and roofed with reeds and palm leaves. The king of Wassanah is called Oleeboo; he is tall and quite young; his palace is very large, square, and high, built of stone with a species of cement. He was said to have a hundred and fifty wives, and ten 
thousand slaves; he has also a very large army which fight with guns, spears, bows, and arrows. When he goes out, he rides on a huge beast, called Ilfement (elephant); and is attended by two hundred guards. The people are not Mooselmins, but addicted to various Pagan superstitions; for which reasons, though they are honest, hospitable; and kind-hearted, Sidi Hamet utters the pious wish, "that they may soon be driven out of this "goodly land."

The following is so important, that we shall give it in the narrator's own words.

"6 The inhabitants catch a great many fish; they " have boats made of great trees, cut off and hol"lowed out, that will hold ten, fifteen, or twenty " negroes, and the brother of the king told one of " my Mooselmin companions who could understand " him, (for I could not,) that he was going to set " out in a few days with sixty boats, and to carry " five hundred slaves down the river, first to the "southward and then to the westward, where they "should come to the great water, and sell them to " pale people, who came there in great boats, and. "brought musquets and powder, and tobacco, and "blue cloth, and knives, \&c.; he said it was a "great way, and would take him three moons to "get there, and he should be gone twenty moons " before he could get back by land, but should be "very rich."-"We saw a great many of these 
"people who had been down the river to see the "great water, with slaves and teeth, and came back " again : they said, the pale people lived in great "boats, and had guns as big as their bodies, that " made a noise like thunder, and would kill all the " people in a hundred negro boats, if they went " too near them."

During Sidi Hamet's stay, which was in March and April, it rained almost daily. He returned by the same route to Tombuctoo.

This narrative, if authentic, is certainly of very great importance. It affords, for the first time, a positive testimony in favour of the Congo hypothesis, and exhibits peculiarities of physical structure, which remove some of the most formidable objections to it. * It displays also a degree of populousness, and some features of civilization, surpassing what have hitherto been observed in any of the native states of Africa." We may instance the building of large walls and houses of stone, and the taming of the elephant. The authenticity of this relation becomes therefore a very important question. The testimonies to the worth and veracity of Riley are so respectable, and he is so liable to be checked by Mr Willshire, and by the yet living evidence of Sidi Hamet, that we con-

* See some further remarks on this subject, Book III. end af $\mathrm{Ch}$. II. 
ceive it impossible to doubt his having received from that person the narrative in question. The fidelity of Sidi is not quite so certain. Yet I confess myself not in general inclined to discredit the testimony of Africans to what they have seen, and have no temptation to misrepresent. The description of Tombuctoo corresponds to that of Adams, with such discrepancies as might happen to inaccurate observers, and as tend even to remove the suspicion of copying. The same may be said of the name Zolibib, corresponding to the Joliba of Park, Gullu, or Julbi of Horneman. Horneman also states (8vo ed. p. 201-5,) that this river in the eastern part of its course is called Zad, and that it there turns rapidly southwards. On the whole, therefore, the presumption seems to be in favour of the narrative ; and it certainly opens very interesting views of the interior of Africa. 


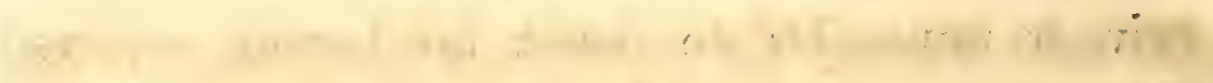
$\therefore+\cdots+4+\cdots+\cdots+\cdots$

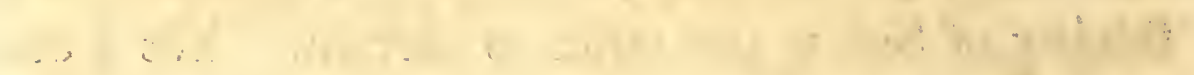
$\ldots+\ldots+1+\cdots$

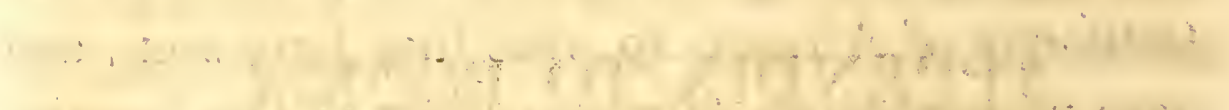
$\therefore \quad \therefore \quad \ldots+\cdots$ . . . $1+\ldots+\cdots+1=\ldots+\cdots$

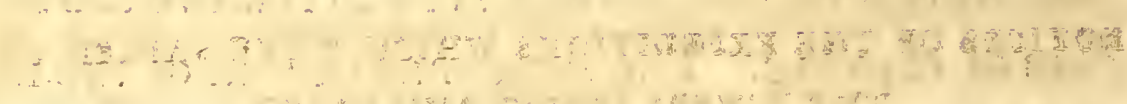
.

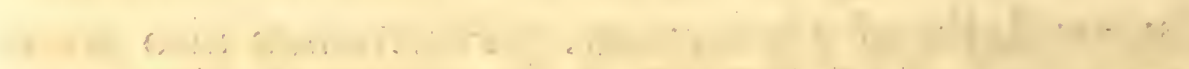

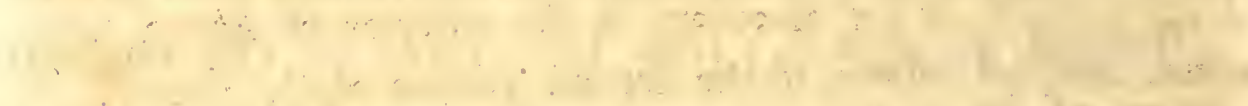

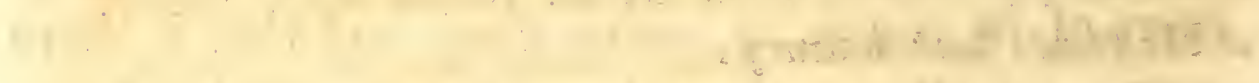

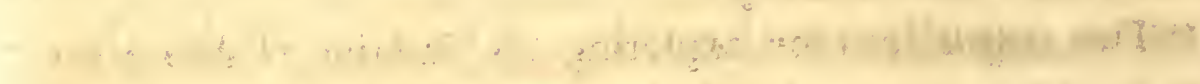

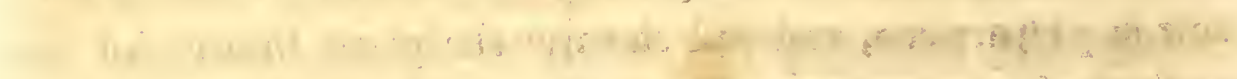

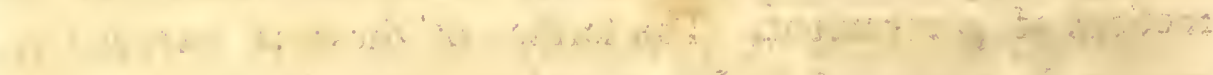

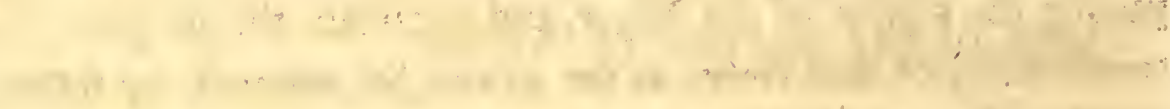

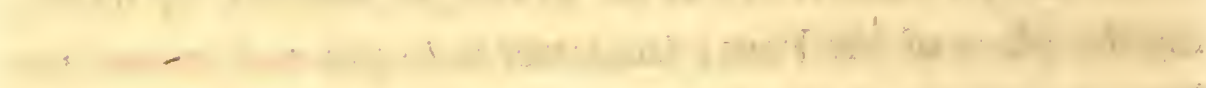
and

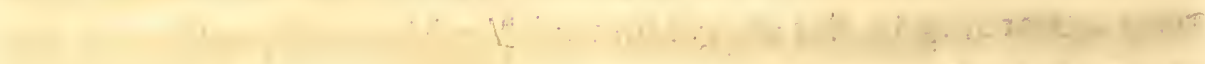

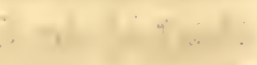

W.

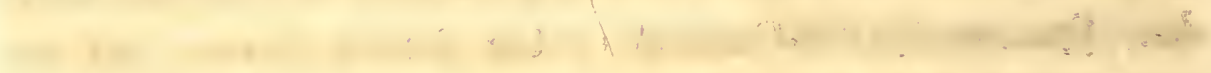

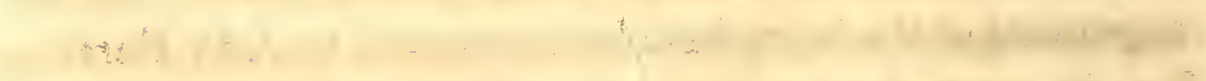

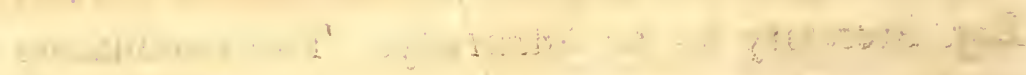

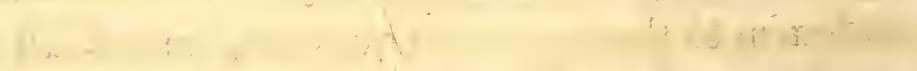

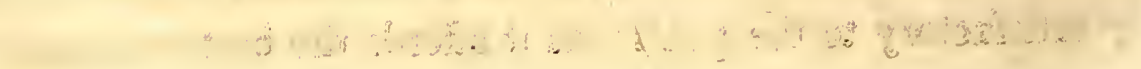




\section{APPENDIX TO BOOK I.}

NOTICES OF THE EXPEDITIONS WHICH HAVE SAILED TO

THE RIVERS CONGO AND NIGER.

THE expeditions for discovery in the interior of Africa are announced, as follows, in the second edition of the Narrative of Mr Park's Last Journey:

"Two expeditions for exploring the interior of Africa are now in preparation, and will shortly take place, under the dim rections of government. The former of these is intended to pursue the course of the Niger, and ascertain the progress and termination of that river, as far as can be effected by following the plans of Mr Park; the latter is to proceed immediately to the mouth of the Congo, and explore the course of that river according to the suggestion of Mr Maxwell, author of the chart of the Congo, and the very intelligent friend of $\mathrm{Mr}$ Park. The duty of directing and superintending the preparations for the former of these important missions has been committed, by government, to Major-General Sir James Willoughby Gordon, Quarter-Master-General of the British forces; the arrangements of the latter have been entrusted to John Barrowo. $E s q$. Secretary to the Admiralty. The nomination of these gentlemen to the services in question, cannot fail to prove highly satisfactory to the public, as it affords the best assurance of 
ultimate success to the undertaking, which can be derived from great zeal and ability on the part of those to whom the care of superintending the preparations is entrusted."

The sailing of the expedition was announced, as follows, in the public prints:

"London, 4th March 1816.

"The Congo, accompanied by the Dorothy transport, is now at the Nore, ready to sail the first fair: wind, on a voyage of discovery up the river Zayr into the heart of Southern Africa. The Congo is about ninety tons, schooner-rigged, and draws about five feet of water. She is fitted up entirely for the accommodation of officers and men, and for the reception of the objects of natural history which may be collected in her progress up the river. The gentlemen engaged in this interesting expedition in the scientific department, are Mr Professor Smith of Christiana, botanist and geologist; $\mathrm{Mr}$ Tudor, comparative anatomist ; $\mathrm{Mr}$ Cranch, collector of objects of natural history; and a gardener to collect plants and sceds for his majesty's gardens at Kew ; besides Mr Galway, a gentleman volunteer There are also two fine blacks, natives of the kingdom of Congo, one of whom was born three hundred miles up the Zayr. The officers are Captain Tuckey, commanding the expedition; Lieutenant Hawkey; Mr Fitzmaurice, master and surveyor; Mr Mackerrow, assistant-surgeon; two master's mates, and a purser. In addition to the Congo, the transport takes out two double whale-boats, so fixed together, as to be able to carry eighteen or twenty men each, and accommodate them under an awning, with three months' provisions. These boats are intended to be drawn up to the upper part of any rapids or cataracts that may occur to obstruct the passage of the Congo."

The result of this expedition was first announced in the following letter: 
"Bahia, 30th October 1816.

"We are enabled to give you a piece of intelligence, which, though not of a commercial nature, will to many be of great interest, - we mean the failure of the expedition sent out by your government carly this year, under the command of Captain Tuckey, whose object was to explore the river Congo. Like all former enterprises of a similar kind, and notwithstanding the presumed discernment and skill of those concerned in the planning and executing of it, there appears to have been $\mathbf{a}$ want of foresight, both as to the time and means. However, as, no doubt, publicity will in due time be given to all their proceedings, it will suffice for us to acquaint you, that yesterday arrived in this port his Majesty's ship Congo, and Dorothy transport, from Cabenda, in 28 days, under the command of Mr Fitzmaurice, formerly master, but who succeeded in consequence of the death of Captain 'Tuckey and the litutenant, both of whom died at sea, the former on the $3 \mathrm{~d}$, and the latter on the 5th inst. It appears that they arrived at the mouth of the Congo about the $3 \mathrm{~d}$ of July, and leaving the transport, (which only accompanied them an inconsiderable distance,) they proceeded in the sloop, which was built purposely to draw litlle water, up the river to the extent of 120 miles, when her progress, and even that of their boats, was stopped by insuperable difficulties, principally, we believe, by the rapids, which they express as beyond all description. Determining still on the further prosecution of their undertaking, the men were landed, and it was not until they had marched 150 miles, (and 120 more than any white person had been before,) over a barren and exceedingly mountainous country, after experiencing the greatest privations from the want of water, and being entirely exhausted by fatigue, that they gave up the attempt. Hope enabled most of them to traverse their route, and regain the vessel; but, alas! nature had been completely worn out, for most of them, say 25 out of 55 , died 24 
hours after their return, comprehending all the scientific part of the expedition; and we believe only eight on board are now in a state to work the vessel; but as their chief want seems to be nourishment, it is to be hoped the others will soon, be brought round. Suspicions are entertained that many died by poison, administered by the Blacks, and Mr Fitzmaurice says, that he is persuaded that he could penetrate an immense way into the country without apprehending danger frum any other cause, as the people are very pusillanimous, and easily intimidated. As a matter of courtesy and expediency, they asked permission of the kings to pass through their respective territories, which was generally readily granted; at the same time, they were furnished with plenty of blacks as guides, at a moderate charge, but latterly advantage was taken of their difficulties. Mr Fitzmaurice and the sur. geon are determined on a new attempt, if the Admiralty will fit out another expedition, and as he thinks he can provide against all casualties, he has great hopes of attaining the desired end.-Yours, \&tc.

$$
\text { S. D. and W." }
$$

Besides the above account, a letter was received from on buard the Dorothy, which accompanied his Majesty's ship Congo on this ill-fated expedition. The Dorothy had reached St Salvador, on the east coast of Brazil, on the 30 th of October, the date of the letter in question, in a miserable state, from the sickness which had attacked the crews of both vessels. Captain Tuckey returned on the 18 th of September to his ship, after having been engaged with eight men in exploring the river, until they were all seized with sickness, and compelled to make the best of their way back for medical assistance. On the $22 \mathrm{~d}$ of the same month, the Dorothy and Congo, with the double boats, proceeded to Cabenda, with a Vew to obtain refreshments, and to try the effect of the sea ou 
the health of the crews. The vessels arrived there on the 27 th, and on the 1 st of 'October they quitted that place, the Congo having lost in all 17 men by death, and having then 32 on the sick list. Captain Tuckey and Lieutenant Hawker, of the Congo, both fell victims to the fatal disease. The command of the Congo now devolved on the master, and it was resolved to proceed to Rio Janeiro. Gunther, the master of the Dorothy, at this time, had his men nearly all sick, but had only lost one, (the carpenter,) and he was drowned by accident. Sixteen of the Congo's men were in a convalescent state. Such was their situation when the ships reached St Salvador. We lament to learn, that when the Dorothy was at Cabenda, there were ten Portuguese ships in the port waiting for slaves, and two from Spain. Professor Smith had died on board the Congo.

The following notice, probably demi-official, was published after the detailed accounts of the expedition had reached the Admiralty :

Melancholy as the result has been, from the great mortality of the officers and men, owing to excessive fatigue, rather than to the effects of climate, the Journals of Captain Túckey and the gentlemen of the scientific departments, are, we understand, highly interesting and satisfactory, as far as they go; and, we believe, they extend considerably beyond the first rapids or cataract. It would seem, indeed, from the extract of a letter from the surgeon of the Congo, inserted below, that the mortality was entirely owing to the land journey beyond these rapids, and that Captain Tuckey died of extreme exbatustion, after leaving the river, and not from fever. The climate, we understand, was remarkably fine; scarcely a shower of rain, or any humidity in the atmosphere, and the sun sel. dom shining out but for a few hours in the middle of the day; Fahrenheit's thermometer seldom exceeding 76 degrees by day, 
and never descending below 60 degrees at uight-such a climate, in fact, as one would wish to live in; but an anxious zeal and over eagerness to accomplish the objects of the expedition, and to acquire all the information that could possibly be obtained, seem to have actuated every one, from the lamented commander to the common seaman and private marine, and led them to attempt more than the human constitution was able to bear. The total number of deaths amount to 18, of which 14 were on the land expedition. They consist of, Captain Tuckey, commander of the expedition; Lieutenant Hawkey, lieutenant of the Congo; Mr Professor Smith, botanist; Mr Tudor, comparative anatomist; Mr Cranch, collec. tor of objects of natural history ; Mr Galway, a friend of Captain Tuckey, who volunteered from pure love of science; $\mathrm{Mr}$ Eyre the purser; the names of the remainder have not been returned. The Dorothy transport, that accompanied the Congo into the river, lost but one man, and he fell overboard and was drowned.

Extract of a Letter from Mr Mackerrow, Surgeon of the Congo.

"Of the eighteen who died in the river, fourteen had been on shore, marching for some time, and were far advanced before reaching the ship.

"Professor Smith, who saw many of them when taken ill, gave to some a dose of calomel, but to others nothing had been administered.

"The fever" appeared in some degree contagious, as all the attendants upon the sick were attacked, and before we left the river, it pervaded nearly the whole crew, also some of the transports; but as for myself, although constantly among them, I did not feel the slighlest indisposition until we left the coast, when I was attacked; however, I considered menta? anxiety and disturbed rest as the sole causes. 
"Captain Tuckey had been afflicted many years with chronic hepatitis, and on returning from travelling five weeks on shore, he was so excessively reduced, that all attempts to restore the energy of his system proved ineffectual.

" Mr Tudor was in the last stage of fever before I saw him, as were Messrs Cranch and Galway.

"Professor Smith died in two days after he came under my care, during which time he refused every thing, whether as nutriment or medicine.

"Lieutenant Hawkey was taken ill after leaving the river, and died on the fourth day: his case was rather singular,the symptoms were, irritability of stomach, with extreme languor and debility, but he had neither pain nor fever.

"Mr Eyre had a violent fever, and on the third day breathed his last: before deati, a yellow suffusion had taken place, with vomiting of matter resembling coffee grounds."

The following letter, written by Captain Tuckey, appeared in the Asiatic Journal for January 1817 :

"Banga Cooloo Yollella, August 20, 1816.

"My Dear Sir,-I have at length reached the obstruction that prevents the farther progress of the boats; the river being filled with rocks for upwards of fifteen miles, and the current running over them with a great velocity, precludes all idea of getting a course up it. The country is besides so mountainous, that it is equally impracticable to convey a boat by land.

"I am therefore about to proceed with thirty men as far as I can by land. I can gain no information from the natives of the course or nature of the river higher up, so that I go on feeling my way in the dark. Provisions are so scarce among the natives, that I carry every thing with me, which is the greatest bar to my progress. Our passage out was terribly long, owing both to the lightness of the winds, the current, and the bad sailing of the vessels. Your ladies would laugh 
to see me, like a captain of banditt, in a cavemn lighted by a candle stuck on a bayonet, and surrounded by muskets, and dirty soldiers and sailors, writing this scrawl on my hat placed on my knee. The climate is, however, so good, and the nights so pleasant, that we feel nu inconvenieuce from our bivouac in the open air."

Major Peddie, it is understood, arrived at Senegal, in the spring of 1816 ; but finding that he could not reach the Niger before the commencement of the rainy season, very prudently determined to remain till it was over. He had an attack of the fever, from which he recovered. In October he set out, but $w \in$ regret to state, that before reaching the Niger, he was taken ill and died. The direction of the expedition then devolved upon Lieutenant Campbell, the second in command, who, by the last accounts, had arriver at the head of the Rio Nunez, and was about to set out for Bammakoo, the point where Park embarked on the Niger.

END OF VOLUME FIRST.

Printed by George Ramsay \& Co.

Edinburgh, 1917. 


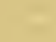

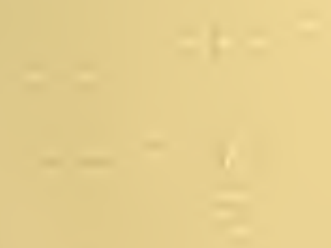





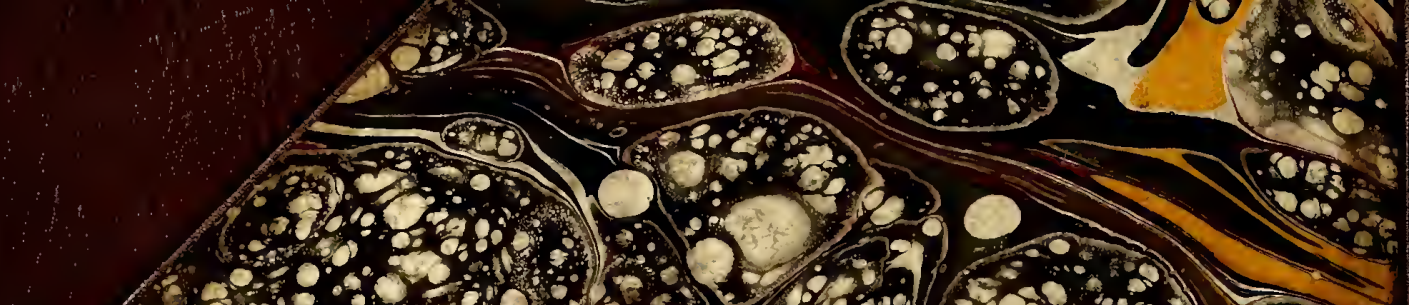

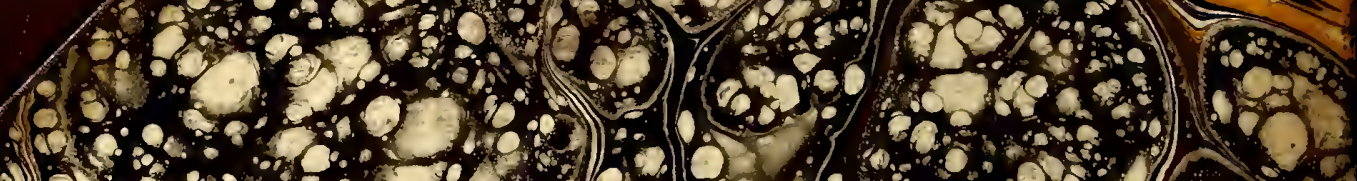

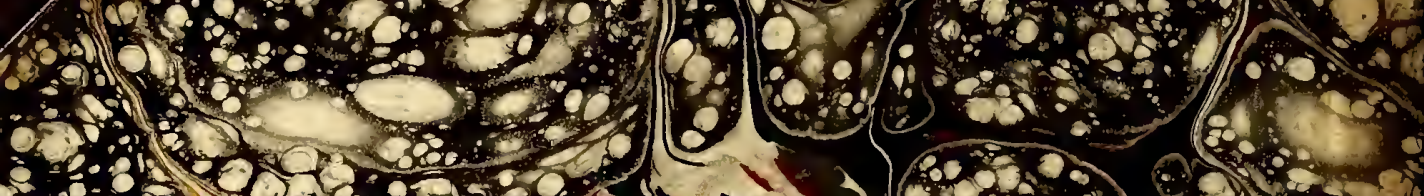

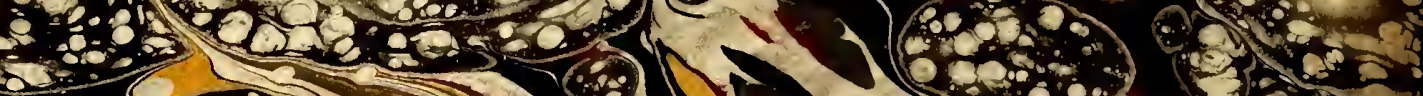

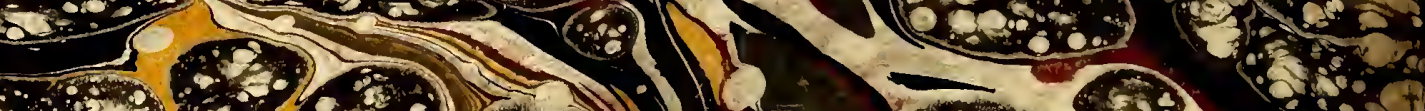

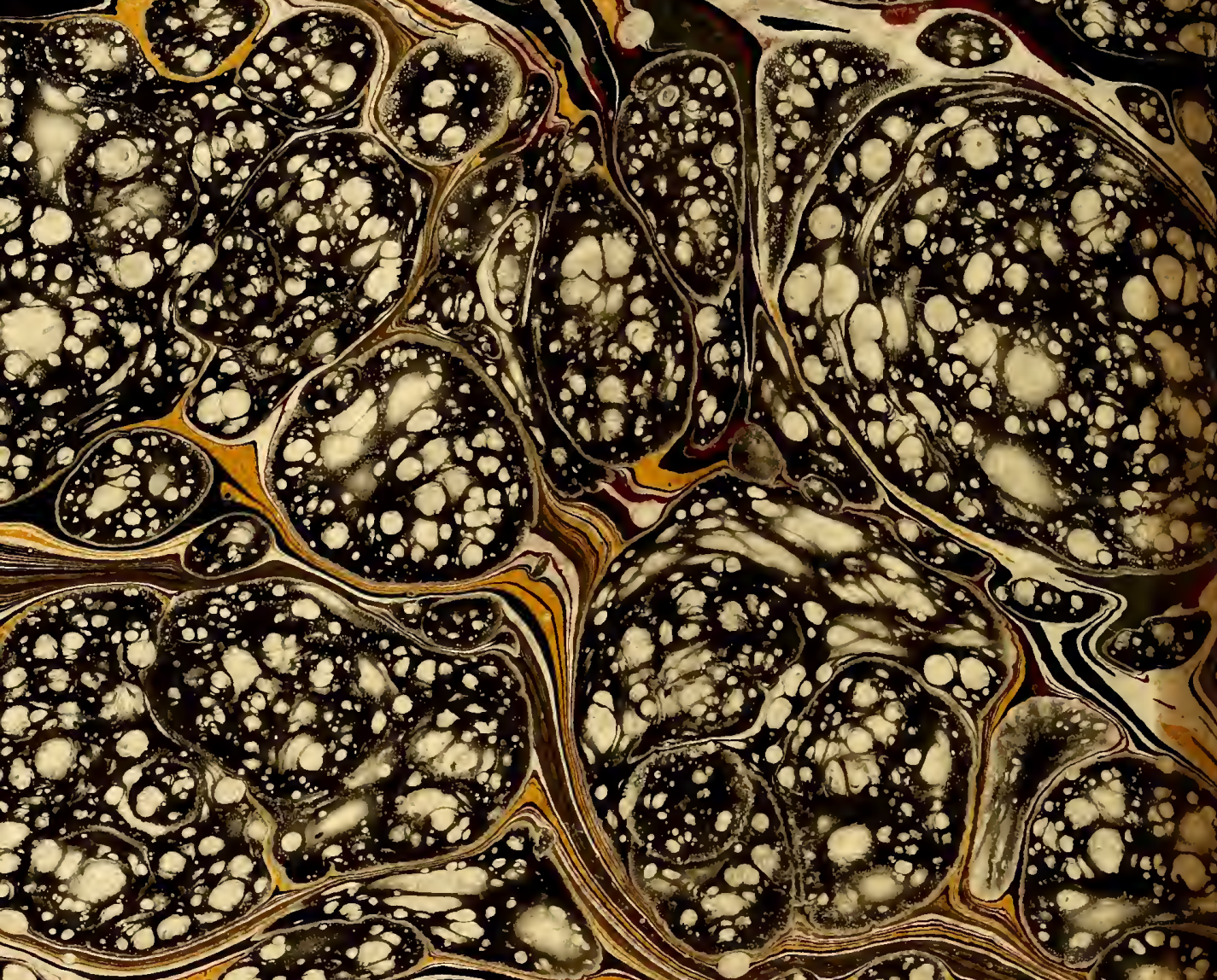

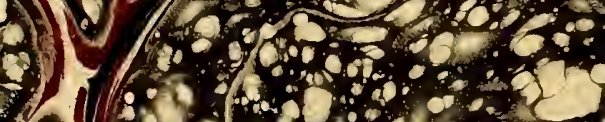

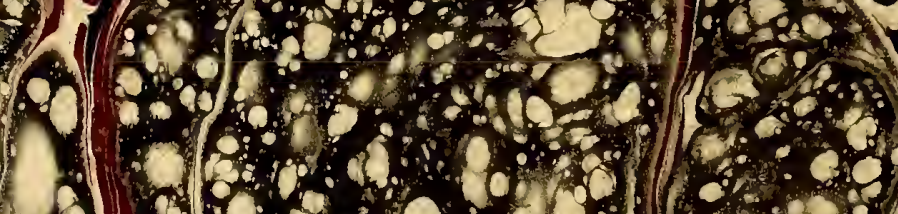

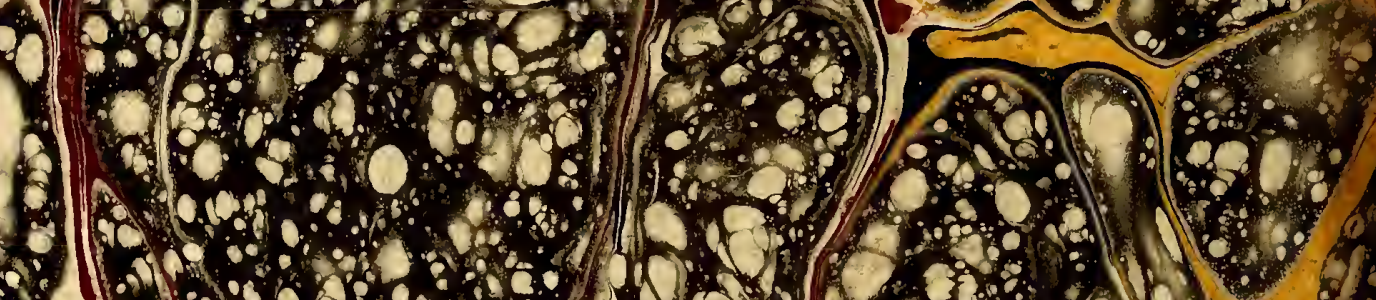

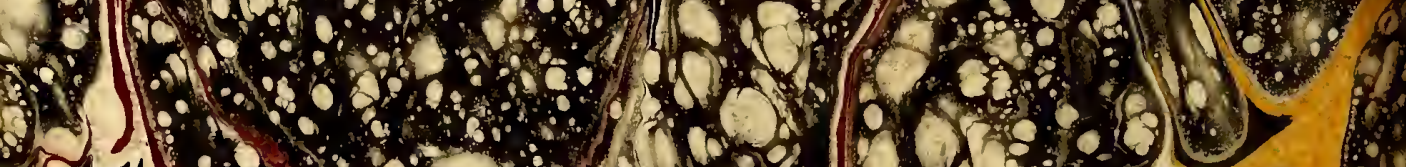

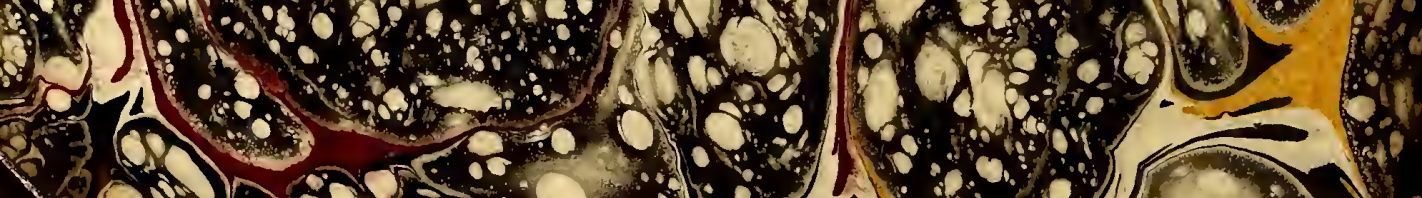

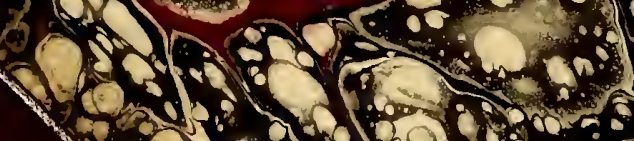

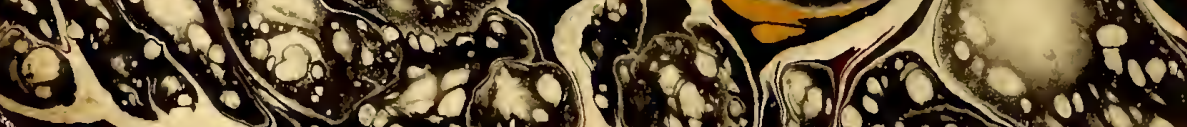

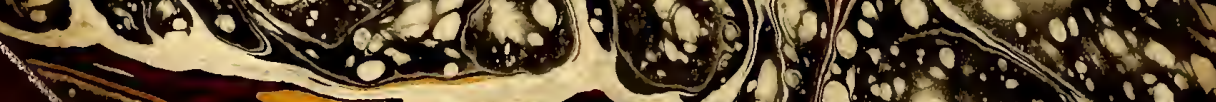

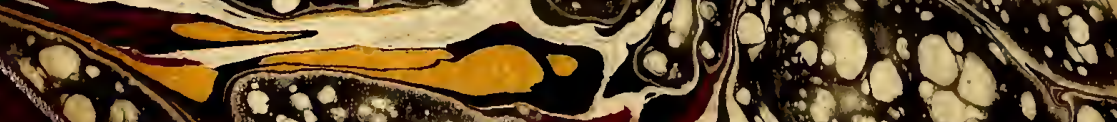

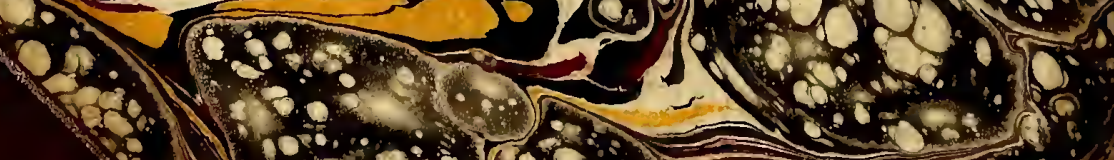

